


\section{Declarations of Independency}

in Eighteenth-Century American Autobiography

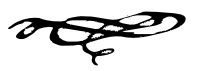




\section{-}




\title{
Declarations of
}

\section{INDEPENDENCY}

\author{
in Eighteenth-Century \\ American Autobiography

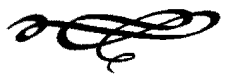

Susan Clair Imbarrato 
Copyright $(\mathrm{C} 1998$ by The University of Tennessee Press / Knoxville. All Rights Reserved. Manufactured in the United States of America. First Edition.

The paper in this book meets the minimum requirements of the American National Standard for Permanence of Paper for Printed Library Materials.

(ळ)

The binding materials have been chosen for strength and durability.

(1)

Printed on recycled paper.

\section{Libraky of Congress Cataloging-in-Publication Data}

Imbarrato, Susan Clair.

Declarations of independency in eighteenth-century American autobiography / Susan Clair Imbarrato. - 1st ed.

p. $\mathrm{cm}$.

Includes bibliographical references and index.

ISBN 1-57233-012-0 (cl.: alk. paper)

1. Autobiography. 2. Biography as a literary form.

3. Self in literature. I. Title.

CT25I45 1998

$808^{\prime} .06692-\mathrm{dc} 21$

97-45369 
To the memory of my mother, Mary Clair Imbarrato, and for my father, Philip Allen Imbarrato, and brothers, Allen and Tony 


\section{Contents}

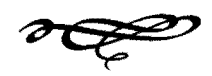

Acknowledgments $\quad \mathrm{xi}$

Introduction xiii

1. From Self-Examination to Autobiography 1

2. Declaring the Self in the Spiritual Sphere: Elizabeth Ashbridge and Jonathan Edwards 14

3. Declaring the Self in the Social Sphere: Dr. Alexander Hamilton and Elizabeth House Trist 40

4. Declaring the Self in the Political Sphere:

Thomas Jefferson and John Adams 86

Conclusion 123

Notes 127

Bibliography 153

Index 167 



\section{Illustrations}

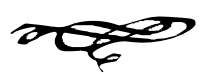

Signatures

Elizabeth Ashbridge $\quad 14$

Jonathan Edwards 14

Dr. Alexander Hamilton 40

Elizabeth House Trist 40

Thomas Jefferson 86

John Adams 86

Maps

Dr. Alexander Hamilton's Journey $\quad 42-43$

Elizabeth House Trist's Journey $\quad 66-67$ 



\section{Acknowledgments}

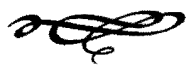

I would like to thank Joyce Harrison and Jennifer Siler of the University of Tennessee Press and Meredith Morris-Babb, formerly at the press, for believing in this project and supporting its publication. I also thank the staff of the press for their assistance and artistry. I am especially grateful to the readers for the press, Emory Elliott and Robert Micklus, who guided me with expertise and wisdom. I have been most fortunate to have had the astute advice and careful attention of this community of editors and scholars.

To the librarians who helped me locate the signatures that appear in this book, I am most appreciative: Sylvia Carlyle from the Religious Society of Friends in Britain; Christina M. Deane and Michael Plunkett of the Special Collections at the Alderman Library at the University of Virginia; Stephen C. Jones from the Beinecke Rare Book and Manuscript Library of Yale University; and Daniel Lewis, Curator of American Historical Manuscripts at the Huntington Library. The staff of Honnold Library at the Claremont Colleges has also been most helpful, and I thank them for their assistance.

I want to thank Wendy Martin for her steady support, keen criticism, and invaluable encouragement. Helena Wall and Constance Jordan read earlier versions of this work and offered provocative, helpful suggestions. A special thank you to James L. Atteberry for introducing me to the conversation of literature and reminding me to listen with care and respect. I also want to thank Annette Kolodny for sharing my fascination with Elizabeth House Trist and generously answering my inquiries. I owe a particular debt of gratitude to Thomas Rochon for his support and his precise, insightful readings. To all, I remain inspired by your scholarly enthusiasm.

And, finally, to my family for their endless support, I dedicate this book.

Susan Clair Imbarrato Claremont, California 



\section{Introduction}

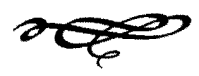

Writing about the self and keeping a record of one's life illuminates the assumption that an individual's life is worth committing to paper. From a postmodern perspective, the individual's voice is assumed important, and anyone who desires to tell his or her story will likely be heard. Recording one's life in a prephotographic world serves as a rare memorial, and so as pioneers race westward, hands furiously scribble the day's events for the sake of capturing the image. In the beginning of the nineteenth century, Transcendentalism intoxicates the individual with self-importance so that such a record is practically obligatory. With democracy clearly embedded in American culture, the autobiographical impulse flourishes in the memoir and diary, which record the possibilities of an American life: the right to learn from one's mistakes and to profit from one's labor, the right to move away from society and philosophize on its dangers, and the right to celebrate success and glamorize acquisition. As this study will demonstrate, the habit of writing about the self is conceived and encouraged as a form of self-examination in which the individual keeps a record of his or her life to enhance spiritual commitment and improve community welfare. Eventually, writing about the self becomes less concerned with appeasing social norms and more interested in setting the individual apart. To track the evolving motives for writing about the self is to watch a growing appreciation for subjectivity in American letters. In so doing, one must begin in a time when the individual self is barely distinct from the larger social community.

In colonial America, people wrote about their lives to teach others how to live a moral life through illustrations of their own struggles and failings, leading eventually to moral triumph. In the case of the spiritual autobiographer, credit was given to God for allowing the pilgrim to overcome deficiencies; for the secular autobiographer, credit was more often given to social influences, parents, and teachers. The following discussion of eighteenth-century colonial and postcolonial American writings examines the changes in the auto- 
biographical voice as it speaks through the transition from a colonial society to the establishment of a New Republic. At the foundation of this study is the question, How does the spiritual act of self-examination culminate in the secular art of self-construction?

\section{Self-Examination in the First-Person Narrative}

Autobiographical writings in seventeenth-century Puritan New England are primarily employed for monitoring spiritual progress and clarifying providential design. The Puritan diarist, guided by doctrinal authority, carefully examines daily events for any reassurance of salvation. The diligent practice of self-examination infuses early American writings with a cautious, constant reminder that while election and salvation may be acts of grace, they may never be taken for granted or too confidently assumed. ${ }^{1}$ Distinct from both prayer and meditation, self-examination is essentially a preparation for both, a type of self-analysis that heightens self-consciousness in spiritual practices. When the early American Puritan looks for outward signs of divine approval to validate election and allay fears of spiritual inadequacy, he or she develops acute powers of self-scrutiny.

Ideally, self-examination strengthens the community of believers immersed in spiritual exercises and devotions as each member's spiritual wellbeing enhances social harmony. This social structure promotes a profound interconnectedness in which individual voices blend to contribute to a communal whole. ${ }^{2}$ Community dependence upon individual support is certainly understandable considering the physical dangers that threatened the earliest colonial settlements. Neither the Bradford nor the Winthrop parties, for example, could have afforded to tolerate gestures of individual autonomy while trying to ward off starvation. In such a formidable environment, only the strongest-willed individuals could have survived. ${ }^{3}$ The Puritan community was thus challenged to subdue the rebellious spirit that initially propelled many to leave established homes and communities in England for the wilds of New England. This maverick energy needed to be controlled and redirected for any sustainable social order to survive. For the Puritans who left the Netherlands and called themselves Separatists, there was yet another challenge. They needed to modify their isolationist tendencies in order to practice greater tolerance for new voices once they settled in New England and thereby prevent what might otherwise be an inevitable splintering. ${ }^{4}$

Protestant reform itself enhances individual perspective by encouraging scriptural study among its members. For the faithful, Scripture is a literal truth, ${ }^{5}$ offering exemplars of behavior which bound the individual by its commands and authority. Although some latitude exists, conflicts arose over who would ultimately determine the interpretation: the minister or the church member. Helena M. Wall observes: "Puritan doctrine itself offered fertile ground for disagreement, of ten less in differences of interpretation than in 
its 'inherent radicalism'" (18). ${ }^{6}$ In some cases, such as in the antinomian controversies, disputes fragmented the community. ${ }^{7}$ Individual perspectives may have been discouraged, but such conflicts can potentially invigorate the community by promoting investigation. ${ }^{8}$ When Scripture itself appears open to interpretation, a similar examination of self can occur. Ultimately, self-examination reinforces one's membership in a community of believers, and it serves as the introspective basis for subjectivity in the first-person narrative.

The tension between individual expression and community control is sustained by an inherent questioning of authority at the core of Protestantism. More specifically, a mistrust of leadership causes Puritanism to question its own authority for fear of replicating the same repression from which it had fled. Larzer Ziff explains that one reaction to the "social deterioration" of the church was to avoid an increase in "external authority" and to work on an "internalizing of authority itself" (Puritanism 14). In bringing the responsibility for the community's welfare to bear upon the individual, New England Puritans aspired to achieve a complicated balance.' Their strength lay in the community's conviction to leave England and sail the Atlantic, and their difficulty was in maintaining consensus without violating individual authority once the passage was completed. Richard Slotkin explains how these aspirations found support on colonial soil, for in "Europe all men were under authority; in America all men dreamed they had the power to become authority" (34). From these radical beginnings the tensions between individual and community required diligent, responsible monitoring.

The wisdom of maintaining and even encouraging these tensions within the Puritan community has been variously interpreted, considered by some as necessary to survival and by others as unduly repressive. Michael Walzer, for one, praises Puritan structures and doctrines for encouraging a "vigorous self-control" and a "bold effort to shape a new personality against the background of social 'unsettledness'" (312). Sacvan Bercovitch holds a harsher view: "[S]elf-examination serves not to liberate but to constrict; selfhood appears as a state to be overcome, obliterated; and identity is asserted through an act of submission to a transcendent absolute" (Puritan Origins 13). Margo Culley offers a more moderate view that, in general, "the individual autobiographical act was ultimately an act of community building" ("What a Piece of Work" 10). Individual benefit is thus dependent upon community benefit. Another possibility is that self-examination builds a new kind of community with more individual authority as constituent elements. Although the individual's subordination by communal structures may be well-founded, this study argues that within that structure selfexamination can potentially cultivate individual authority by bringing the individual closer to self-knowledge.

In drawing these broad comparisons between the seventeenth- and eighteenth-century colonial American self, I am most interested in how the firstperson narrative takes on a stronger sense of its own subjectivity, one that is grounded in its relationship to a larger social unit but not merely derived from 
the demands of community welfare. ${ }^{10}$ I also acknowledge that the eighteenth century is closer in temper to its Puritan communal foundations than to its Romantic progeny, and thusits first-person narratives generally express a greater appreciation for community unity than individual distinction. ${ }^{11}$ Moreover, although individualism is often associated with an autonomy enjoyed primarily by men, this study finds that both genders benefit from daily acts of self-examination by developing a self-awareness that articulates individuality.

While gender differences in individual autonomy of action will be apparent in the studies presented in this book, self-examination especially benefits the female by providing a legitimate private sphere for self-reflection. Traditionally, it was the man's role to keep a record of self-examination as part of the family journal. Anne Bradstreet's poetry illustrates an exception of female authorship by successfully integrating the domestic with the spiritual in poems that speak of home, children, and husband within larger concerns for her salvation. ${ }^{12}$ Bradstreet's poetry thus evokes the first-person within the prescribed boundaries of the Puritan community. It is the motivation to look within that gives her poetry its "personal" voice. Where Bradstreet is embraced for her acts of self-examination, however, Anne Hutchinson is banished for interpreting Scripture without the help of the church fathers. Ivy Schweitzer examines such contradictions and finds that the "hegemonic" Puritan doctrines and social practices subordinate and exclude women from church government (36). ${ }^{13}$ Notwithstanding such inequities, self-examination does allow the female Puritan an opportunity for personal reflection.

Eventually, an increased secular population ${ }^{14}$ will challenge the Puritan's tightly knit community, and female expression will benefit from a general campaign for individual rights. There also will be greater possibilities for female expression in the New Republic than exist either in Britain or on the Continent. Drawing upon this socially sanctioned sphere for self-reflection, the eighteenth-century women in this study evoke self-examination to understand critical events and facilitate necessary changes. In fact, the female authors are generally more willing to expand their socially defined gendered roles than the men, who tend to reinforce theirs. For both genders, the aggrandizement of self-expression will find its ultimate manifestation in the American Transcendentalist movement. The development of a profound respect for individualism is epitomized in Ralph Waldo Emerson's injunction to "Insist on yourself; never imitate." The writings under investigation in the following chapters thus initiate a process that redefines individual expression in the first-person narrative.

\section{From Self-Examination to "Declarations of Independency"}

Expressing one's individual perspective has been either praised or discouraged, depending upon larger structures of authority. ${ }^{15}$ For colonials, who were beholden to the crown and the church, autonomy was discouraged and only 
actions sanctioned by the community were deemed acceptable. Within a social context in which community solidarity is highly valued, first-person narratives of diaries and journals are expected to conform to this standard. ${ }^{16}$ The Puritan would not be encouraged to filter experience through a private, self-interested lens, which would upset community consensus. Instead of delineating differences, the Puritan is encouraged to imagine him or herself as part of a communal mission. ${ }^{7}$ Individual strength is determined by divine will, as William Bradford confirms in Of Plymouth Plantation when he asks, "What could now sustain them but the Spirit of God and His grace?" Bradford reinforces providential design by suggesting that less divinely inspired travelers would not have withstood the pervasive dangers that confronted the Mayflower voyagers. John Winthrop also emphasizes the importance of mutual dependence in his impassioned sermon "A Modell of Christian Charity": "[E]very man might have need of other, and from hence they might be all knitt more nearly together in the Bond of brotherly affeccion" (293). Winthrop goes on to define each member's role in a community of believers devoted to upholding providential design, concluding with a vision that assumes a collective responsibility for self-monitoring: "[F]or wee must Consider that wee shall be as a Citty upon a Hill, the eies of all people are uppon us." As Winthrop figuratively prepares them to go forth "to possesse" this new land, self-examination serves a dual purpose: to inspire religious allegiance and reinforce social order. ${ }^{18}$ In each case, the individual's point of view is clearly subordinated to the community vision. In the following first-person narratives, I will trace the connections between the communal origins of American thought and an emerging sense of the individual voice within an eighteenth-century context that moves away from a monarchical subordination of the individual and that anticipates a democratic celebration of the self.

When the practice of self-examination occurs within a communal, seventeenth-century spiritual context, it reinforces the individual's limitations; this same act within a more democratic, eighteenth-century secular context inspires individual expression. As the habit of self-monitoring carries over into eighteenth-century America, the practice of self-examination expands from an exclusively spiritual context to incorporate more secular concerns. In tracing this connection, the change from a predominantly spiritual context for self-examination to a more secular application is underscored by the eventual separation of church and state in the New Republic. The diarist does not, therefore, suddenly abandon one concern for another but instead builds upon a foundation of introspection. The eighteenth-century diarist turns his or her skills of examination both inward to gauge moral fortitude and outward to assess worldly potential.

Self-reflection in the revolutionary era fosters new perspectives about individual rights that called for a new social order and threatens seemingly invincible social constructs. It is in this climate of social change that on March 31, 1776, Abigail Adams writes her husband, John, from the family home in Braintree: 
I long to hear that you have declared an independancy-and by the way in the new Code of Laws which I suppose it will be necessary for you to make I desire you would Remember the Ladies, and be more generous and favorable to them than your ancestors. Do not put such unlimited power into the hands of the Husbands. Remember all Men would be tyrants if they could. If perticular care and attention is not paid to the Ladies we are determined to foment a Rebelion, and will not hold ourselves bound by any Laws in which we have no voice, or Representation. (Book of Abigail and John 121) ${ }^{19}$

Two weeks later, on April 14, John Adams, in Philadelphia attending the Second Continental Congress, answers with this lively, provocative response:

As to Declarations of Independency, be patient. Read our Privateering Laws, and our Commercial Laws. What signifies a Word.

As to your extraordinary Code of Laws, I cannot but laugh. We have been told that our Struggle has loosened the bands of Government every where. That Children and Apprentices were disobedient - that schools and Colledges were grown turbulent-that Indians slighted their Guardians and Negroes grew insolent to their Masters. But your Letter was the first Intimation that another Tribe more numerous and powerfull than all the rest were grown discontented.-This is rather too coarse a Compliment but you are so saucy, I wont blot it out.

Depend upon it, We know better than to repeal our Masculine systems. Altho they are in full Force, you know they are little more than Theory.... We are the subjects. We have only the Name of Masters, and rather than give up this, which would compleatly subject Us to the Despotism of the Peticoat, I hope General Washington, and all our brave heroes would fight. (Book of Abigail and John 122-23)

The radical notion of breaking free from British rule inspires Abigail Adams to consider the elimination of other oppressions. The opportunity to rewrite traditional notions of government encourages her to imagine new perceptions of female authority despite her husband's reluctance to repeal "Masculine systems." Abigail Adams's "saucy" appeals call for significant social reform. By reminding her husband that tyrannical behavior is the inevitable result of "unlimited power," Abigail Adams targets a key revolutionary concern for representation. Why then, she asks, are boundaries being drawn to exclude women in the call for individual rights? John Adams acknowledges that the "Masculine systems" are little more than "Theory," even as he makes a conservative's plea for her patience. And while Adams and his fellow legislators are "Masters" in name only, he still resists entertaining a more inclusive platform for social reform. The "Despotism of the Peticoat" presents a mock fear greater than colonial subjugation. This exchange illustrates the turbulent conditions in the eighteenth century which allowed for new manifestations of self-expression. 
Declaring an "independency," therefore, is an intentional assertion of individual expression, a bold act that confidently embraces the risks of moving in new directions, which is already possible for many of the men and is becoming increasingly possible for the women. This declarative spirit informs each of the six writings in this study. Within the larger theoretical frame of New Historicism, which incorporates social, economic, and political factors in assessing cultural conditions,$^{20}$ this introductory study of eighteenth-cen tury autobiographical writings focuses upon six different authors who represent three different aspects of this literary form-the spiritual, the social, and the political.

In the spiritual sphere, Jonathan Edwards and Elizabeth Ashbridge practice self-examination to bring them closer to conversion. Ashbridge's Account explains how a Quaker who is encouraged to follow an Inner Light can explore self-reflection without threatening community expectations. In Edwards's Personal Narrative, his examination describes a more intimate relationship between self and God, one that is enhanced by the beauty of nature. Despite the fundamental differences of their doctrines, each narrative allows the individual a strong central presence through which the rigors of conversion are expressed. In the social sphere, self-examination enhances the traveler's powers of observation. Elizabeth House Trist's Travel Diary and Dr. Alexander Hamilton's Itinerarium illustrate this move toward subjectivity as each author travels along the expanding network of roads and leaves a record of his or her journey that reflects a particular, individuated perspective. In the political arena, self-examination gives rise to personal opinion with less concern for public criticism and more interest in freedom of expression. The Thomas Jefferson and John Adams autobiographies offer extensive social and political commentary in the hope of setting the public record straight. Published in the beginning of a new political age, their writings appeal to reason, balance, and order and promote a call for greater individual authority. In each sphere, the connections between self-examination, self-presentation, and self-construction are evident. All are manifest through a more autonomous narrator.

Along spiritual, social, and political lines, each narrator expresses new possibilities for the autobiographical voice. When the narrator moves closer to the center of the text, he or she validates a first-person point of view. The six autobiographical writings in the following chapters mark an assertion of self-expression borne from self-examination which signals the development of subjectivity in eighteenth-century American discourse. 



\section{Chapter I}

\section{From Self-Examination to Autobiography}

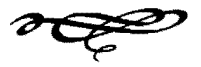

The relationship between self-examination and self-construction in early America must be understood within the context of a communal body politick in which social approval takes precedence over self-promotion. The colonial Puritan assumes an ob ligation to the community, while the postcolonial individual asserts the right to speak independently. For the Romantic, separation from the community of ten enhances self-understanding, and the autobiographical narrative explores solitude for all its illuminations. If the colonial Puritan takes up the first-person to contribute to the community and the Romantic does so to celebrate self-expression, the eighteenth-century autobiographer uses the first-person to explore the domain between conformity and independence. Whether the autobiographical voice reinforces or differentiates, it represents an intersection between language, self, and society wherein the author constructs an identity.

The leap from self-examination to autobiography, therefore, requires the individual to refigure his or her perceived relationship with the community. Before any individual speaks in the first-person, he or she considers the social value of the narrative, its instructive or inspirational qualities. The Puritan mistrusts self-aggrandizement and finds exaggeration suspect; by contrast, the 
Romantic embraces introspection and fosters embellishment. From an Enlightenment point of view, the first-person narrative is an affirmation of experiential knowledge, a celebration of an empirical perspective guided by a zeal for individual rights. If we look forward, then, from a period in which permission to speak in the first-person is highly regulated and compare it to a period in which the same narrative flourishes, skepticism yields to appreciation. This study is located here, within this momentary stay of suspicion and distortion, allowing the autobiographical narrative to declare the self as a work in progress moving from self-examination to self-construction.

\section{Readings of Autobiography}

True to its Romantic implications, the term "autobiography" has been traced to Robert Southey, who in 1809 "coined or translated the word for the Quarterly Review, [so] that 'autobiography' became a familiar designation in England." ${ }^{11}$ A century later, in 1907 Georg Misch offered this etymological explanation of the term "autobiography": "the description (graphia) of an individual life (bios) by the individual himself (auto). ... a a word formed artificially, like the technical terms of science, with the aid of the ancient Greek language ..." (5). Autobiography is thus an inherently self-reflective act in which the author makes certain choices in the retelling of his or her life. By piecing together separate events, the autobiographer weaves them into a coherent narrative to construct a unified textual self. ${ }^{2}$ To evoke the autobiographical voice, the author then takes up a mask through which he or she will speak. Whether the masks are spiritual, social, or political, they have been formed by some degree of self-examination.

Autobiography as an act of self-representation illustrates how the patterns of each life develop into a unique life story. ${ }^{3}$ These patterns may appear to surface organically and follow a chronological order that confirms a logical outcome. The narrative may also be deliberately constructed to capture an idealized self. Appearing objective and inherently rational, this autobiographical voice reinforces authenticity, as if the text announces, "here are the events and here are the results." Yet, if the autobiographer exercises too much selfediting and becomes too concerned with audience approval, the text sacrifices credibility. The autobiography that claims to be a "truthful" representation will also be variously interpreted, as one may doubt the possibility of an absolutely accurate presentation. These concerns are intensified when the style and construction of the narrative becomes more important than its content, in which case the autobiographical narrative is of ten read for its performative quality rather than for its didacticism. In reading autobiography, therefore, assumptions are inevitably made about the author's intentions. ${ }^{4}$

Another underlying problem in reading autobiography is determining the relationship among experience, language, and representation. One choice is to assume that language cannot reflect experience without an element of distortion 
or deception. Once any action occurs, language already exists in the past tense, and language is an inadequate tool for representing reality. The very separation between the act of living and the act of describing a life prevents an accurate retelling. ${ }^{5}$ Unless one decides that language adequately interprets and replays experience, the critic who finds self-knowledge to be oxymoronic will probably assume that all autobiography is fictional, for one can never really know one's self. Patricia Meyer Spacks notes that "people do ma ke themselves up.... To read an autobiography is to encounter a self as an imaginative being" (19). From this view, autobiography moves closer to a fictional narrative, as in Moll Flanders, than to an historical document, as with Mary Rowlandson's Narrative of the Captivity, and authenticity is chimerical. If one writes the autobiography to uncover some truth, the author has then made assumptions that language can convincingly represent reality without distortion. The reader who does not believe that the subject can know him or herself in any objective sense, however, will likely view the text as a fabrication of self. To varying degrees, therefore, writing the autobiography provides the author with knowledge of the self, and reading the autobiography provides the audience with an understanding of how that person's story evolved. One's intentions may or may not coincide with either the outcome or the interpretation, which makes the autobiography a rich source for literary study.

Whether the autobiography is intended to reveal the author's self-knowledge or promote the author's accomplishments, understanding motives and intentions is complicated by the audience's expectations for the truth. The audience listens for sounds of "truth" or of "masking," and the autobiographical voice appears either transparent or opaque. Paul de Man insists that the author and the reader share a conspiratorial role, for autobiography is "a figure of reading or of understanding that occurs, to some degree, in all texts" (70). This relationship leads to the reader's assumption that somewhere hidden within the autobiographical text lies the true self of the writer. ${ }^{6}$ The readeras-detective uncovers the contradictions between meaning and content. The risk in this interpretative approach is that the autobiography will be subjected to the reader's own projections and the "true" story of the narrative will be obscured. The autobiographer's task is to draw conclusions about his or her identity and then portray this past from a present perspective. Philippe Lejeune recognizes this temporal gap and offers two different intentions. The first is to convey "the writer's past, the story of his life," and the second is to engage in "telling the truth about the past; its contract implies the possibility of some kind of verification" ("Genetic" 2-3). Autobiography thus aspires toward the "possibility" of truth.

In trying to determine whether truth exists in the autobiography, Timothy Dow Adams silences one side of this debate with the assertion that "[a]ll autobiographers are unreliable narrators, all humans are liars." He then dismisses the autobiography as not meant to be "historically accurate" and prefers to thin k of it as "metaphorically authentic" (ix). For Adams, autobiography is essentially a 
"story of an attempt to reconcile one's life with one's self" (ix). To accuse all autobiographers of deception solves one problem of interpretation, in that it treats the genre as fiction. ${ }^{8}$ Certainly, autobiography tends toward a dramatic retelling of the author's life making distortion possible. The autobiographer may fall short of accurately representing his of her life, but the text can still serve as a therapeutic form of self-construction by providing the author with some degree of insight. We thus glimpse the author's self-perception in this psychologically encoded text. To some extent text and life mirror each other in that neither may be certain of how it ultimately will be interpreted. Autobiography is thus simply a relative account of a life, relative to the purpose for which it was written and the audience for whom it is intended. The accuracy or truth of this representation may or may not bear upon the reader's appreciation of the autobiography. It can be read for pleasure or instruction.

For the eighteenth-century author, autobiography might be better viewed as a representation of self, one that reflects certain social constructions. ${ }^{9}$ For example, John Locke's recognition that language is not stable and is therefore subject to change challenges the fundamental relationship between ideas and reality. Knowledge gained through sensations and experience favors the uncertain in order to discover the unknown and radically interrupts the Puritan's equation between intention and consequence. While this perception encourages discovery and change, it also increases anxiety. To eradicate such instability, Alexander Pope's claim in An Essay on Man that "One truth is clear, 'Whatever Is is RIGHT'" reinforces a Great Chain paradigm which promises a dependable, static universe (1.294). Empirical investigations, however, subject all relationships between self and society to questioning. As a result, the individual's impact upon the immediate environment is recognized as contingent, within the power of the individual to choose and shape. ${ }^{10}$

The eighteenth-century autobiographer is thus free to rework the traditional form of self-examination and introduce several narrative innovations. Segments or fragments of one's life, for example, might be presented in an episodic manner that when read as a unit tell a coherent story. For the modern reader, narrative fragmentation may not necessarily be a liability, which has allowed a rereading of texts once considered marginal to reach new stature as literary documents. ${ }^{11}$ Historical documents, such as the slave narrative, travel diary, letter, and journal, may be read as literary texts and appreciated as narratives regardless of their sequence or comprehensiveness. To consider autobiography as a literary genre has some benefits, according to Paul de Man, for it elevates it "above the literary status of mere reportage, chronicle, or memoir and gives it a place, albeit a modest one, among the canonical hierarchies of the major literary genres" (66). Where a letter or narrative may only present a section of an individual's life, therefore, this "section" may now be read as a cohesive unit. ${ }^{12}$ Autobiographical narrative can thus represent one particular version of one's life at any particular time. When the part can be appreciated for its own coherence, the "fragmented" text gains credibility. The 
episodic structure of the diary, for instance, has been viewed as a somewhat inferior version of autobiography whose more fluid structure might suggest a clearer sense of self. ${ }^{13}$ One might argue, however, that as diaries are fundamentally episodic, broken off here and there by domestic and community needs, the diarist may not be concerned with continuity or synthesis. Although the autobiography may appear temporally coherent, it too is subject to interruptions and breaks. ${ }^{14}$ In both the diary and the autobiography, therefore, the narrative is affected by some degree of fragmentation and subject to editing. A unified narrative is especially difficult to create if one considers that autobiography is an interior monologue given an external voice, causing the autobiographer to look simultaneously inward and outward as if turning oneself inside out. Anna Burr elaborates: "[O]ne must be prepared to find in self-study a certain looseness as to exterior matters. The eye cannot look both in and out at the same time" (46). Despite the author's potential for distortion, linearity may or may not be a requisite for determining accuracy. Some degree of authorial distance must exist for an accurate representation..$^{15}$ In the eighteenth-century, where traditions are shattered and lives are being redirected, life stories can be reconstructed along new lines of thought and form.

Autobiography consequently lends itself to the rigors of literary interpretation as the reader approaches the text with these various assumptions. The text shows us where the author has been, and we subscribe meaning to these adventures. For the author, the notion of progress seems relative. The spiritual autobiographer presents a life guided by divine will, and progress is measured by one's submission and acceptance. In the travel narrative, progress is marked by an exterior path and guidance is provided by those who can best navigate the route. For the political autobiographer, guidance is ideally a moral force and progress is measured by advancement toward the desired goals of the polity. For the female narrators in this study, control over external circumstances is less certain. Yet their texts are often richer in self-disclosure than the male narratives because they connect the lessons of self-examination most directly with the events of their lives. ${ }^{16}$ The male authors clearly know where they are going, how to arrive at their destinations, and what obstacles to expect. This confidence allows them to narrate their lives with a greater sense of self-promotion than the female authors in this discussion. Where the female is willing to express doubt, the male asserts an opinion. Each autobiographer demonstrates a conscious act of self-editing and provides a map of his or her life unified not only by chronology but by patterns that emerge from constructing the textual self.

Committing one's life to a comprehensible narrative requires choices that lend each autobiographical text its singularity. The instructional autobiography is therefore different from the confessional one. The first relates individual experience in order to teach an audience about social codes and inspire individual performance; the second emphasizes individual reflection and often projects a desire to withdraw from society. ${ }^{17}$ The following eighteenth- 
century narratives share common ground as culturally constructed images of self; each educates an audience, promotes social unity, and practices selfexamination.

\section{Self-Examination and the Puritan Diary}

Within the Puritan's providential framework, the notion of self and its relationship to a first-person narrative is far more direct, if not simplified; it is tied to a belief in causal relationship between interior forces, thoughts and prayers, and exterior forces, actions and rewards. The physical world mirrors the spiritual, and the faithful scrutinize phenomena for reassurance of their standing in the graces of God, with the larger understanding that one's ultimate reward is in heaven rather than on earth. The Puritan employs selfexamination to monitor spiritual progress, and this endeavor is then recorded in the journal or diary. ${ }^{18}$ Self-expression is further defined in a preference for a "plain style," for any act of self-aggrandizement would certainly have been discouraged if not condemned as blasphemous. The implication that "plain" connotes "purity" reinforces the state of election. The Puritan looks both outward and inward for signs of election, and as Karl Weintraub suggests, he or she seeks to decipher "a sign of the works of God within him" (Value 230). The Puritan's diary is essentially a study of cause-effect relationships within a larger context of self-examination. ${ }^{19}$ The diary's inherent subjectivity is tempered by the larger intention of praising God or examining one's spiritual state. It is also not a private document but more of a family ledger used to record births, marriages, deaths, crops, finances, and civic events in addition to keeping a record of the family's spiritual health. ${ }^{20}$ Kenneth B. Murdock explains that the Puritan autobiography "was usually circulated in manuscript among a family and a group of friends, since there were obvious dangers that a man who made public the story of his own life might seem to be sinfully exalting himself" (118). Appropriately, then, John Seelye reminds us that the "first published sermon delivered in Puritan America was entitled The Sin and Dangers of Self-Love" (126). The Puritan's self-imposed modesty stems from a providential world view, whereby one justifies his or her fortunes and misfortunes as acts of divine will. Perry Miller finds that it was impossible for the Puritan "to segregate a man's spiritual life from his communal life" (Errand 142). And where this fear of self-aggrandizement pertains particularly to the Puritan diary, its secular counterparts, the exploration narrative or promotional tract, are, of course, more self-promoting. ${ }^{21}$ Still, the Puritancolonial individual is tightly governed, and the diary reinforces this structure by mediating individual behaviors.

In The Diary of Samuel Sewall, for example, the author engages in personal observations of God's will without drawing undue attention to his own individualistic perspective. A typical entry records the weather, births, marriages, arrivals, departures, legal proceedings, and deaths of his Boston community: 
Nov. 11 [1675]. Morning proper fair, the wether [sic] exceedingly benign, but (to me) metaphoric, dismal, dark and portentous, some prodigie appearing in every corner of the skies ... (1:12). Satterday, June 27th [1685]. It pleaseth God to send Rain on the weary dusty Earth ... (1:68). Wednesday, p. M., July 15 [1685]. Very dark, and great Thunder and Lightening. One HumphryTifinny and Frances Low, daughter of Antony Low, are slain with the Lightening and Thunder.... the Horse also slain, that they rode on.... the sad Bill was put up with [regard] of that Solemn judgment of God ... (1:71). July, 1 [1707]. A Rainbow is seen just before night, which comforts us against our Distresses ... (1:568). March, 4. Lord's Day [1711]. To my apprehension God assists my Son remarkably in prayer and preaching. I hope tis an Answer of my prayer last Midweek. (2:655)

For Sewall, natural phenomena convey divine meaning. Thunder and lightning portend the awful power of Providence; rainbows are cause for reassurance. Nature bears signs of God's "Solemn judgment" or "comforts," and Sewall's acceptance of and delight in these signs suggest that he was, as David D. Hall offers, "aware of portents that betokened either God's anger or his protection of the colonists" (Worlds 221). For the Puritan, God speaks a symbolic language. ${ }^{22}$ Sewall attempts interpretation by noting his own observations and looking for divine signs, which heighten his investigative skills. ${ }^{23} \mathrm{He}$ "reads" nature to understand divine messages, and he comments on society to reinforce community values: ${ }^{24}$

Third-Day, July 11. 1699. I went with Mr. Willard to Pulling-Point to Mr. Dean Winthrop's, (77) annorum. Between one and two, Mr.Willard married Atherton Haugh and Mercy Winthrop: Said, Mr. Atherton Haugh, Mrs. Mercy Winthrop; forbad all unlawful communion with other Women and vice versa. Gave very good Advice and Exhortation; especially most solemnly charged them never to neglect family Prayer.... And after, when saw the Bridegroom and Bride together after the Wedding: I praid God to bless them, and give them such an Offspring wherein the name of Haugh and Winthrop might flourish. (1:412)

The passage shows how family prayer anchors the individual members in a larger context by reminding them of their duty to God and community. Sewall's blessings for "offspring" encourage the couple to perpetuate both their family's name and the community's longevity. No single individual is praised for unique qualities but rather for his or her contributions to a larger genealogy. From such passages, Sewall's diary serves as self-monitor and community regulator of spiritual and social laws.

These interpretive skills work interchangeably within and without the individual. When Sewall focuses his examination outside of himself, his diary describes a social structure that thrived on the oral culture of gossip. On March 29,1695 , Sewall illustrates the rapidity with which information is disseminated: "Went to the Meeting at Mr. Olivers: Major Walley sat next me, and presently 
after the Exercise, ask'd me if I heard the sad News from England, and then told me the Queen was dead, which was the first I heard of it. It seems Capt. Allen arriv'd yesterday at Marblehead, who brought the News, and fill'd the Town with it this day" (1:329). Information takes on a tangibly visual quality with its apparent capacity to fill a town. Language is the mediating factor for experience and, whether written or oral, subject to interpretation and misunderstanding. Clearly, gossip keeps people informed and connected. Sewall values this specific information by placing it within a larger social context, which signifies the daily integration of the ecclesiastical and secular.

Oral culture also articulates the standard against which behavioral norms are established and new social codes emerge. Sewall's depictions of an animated, highly scrutinizing Puritan society suggest what Helena M. Wall calls "a fierce communion," where "community expectations of neighborhood behavior were so great that they of ten proved impossible to meet" (17). Wall's archival study confirms what the sheer volume and scope of Sewall's notations suggest: that individual actions were closely examined under a community microscope; as Wall explains, "Colonial neighbors had assumed not only the right but the duty to supervise one another's lives" (134) ${ }^{25}$ Unity is thus obtained at the expense of more individual expression. Sewall himself is frequently critical of others: "March 2. Monday [1713] .. James Penniman was buried last Lord's-day night. ... He had been such a Drunkard and Idler that I went not to the Funeral, having no heart in it" (2:707). Through Sewall's entries, not only are social expectations and behaviors reinforced, but the diary itself encourages his particular observations and thereby promotes the seeds of subjectivity in the first-person narrative. ${ }^{26}$

Samuel Sewall exercises acute powers of observation arising from his daily practice of scrutiny and examination. He then reads the signs of daily life for divine messages and reinforces the view that natural events serve as mediators of divine intent. Sewall also illustrates the absence of confessional selfexamination and provides a kind of base line upon which the diary will build. When eighteenth-century scientific inquiry causes this model to change, more value is placed on individual perspective and observation itself takes on a sense of mastery. ${ }^{27}$ The shift also forces a reexamination of all premises concerning truth and knowledge.

The individual who is trained to filter sensations and record events through a spiritual lens begins to refocus this inward gaze outward and question external reality. Where scientific classifications and divisions of plants and animals identify genus and distinguish species, the human becomes yet another area of study. A family tree, for instance, reveals certain characteristics that identify a distinct lineage, and the individual family is even further differentiated from the larger community. As scientists begin to formulate answers to cosmological questions, divine explanations are somewhat demystified, and knowledge itself is no longer considered a static entity. Questioning the external world will suggest interior manipulation for the individual who ex- 
plores the possibilities of self-construction. Such investigation promotes an individual's confidence that his or her particular perspective is indeed unique and noteworthy.

The link between the self-examined diarist and the self-concerned autobiographer is made possible through the diary's inherently investigative and contemplative form. The shift from a diary that discourages subjectivity toward a text that values the individual's voice begins within this spiritual and empirical context. David S. Shields, in fact, credits the Reformation for creating "a critical public" whose "independence derived ultimately from the permissions accorded the private conscience" (xi). The Puritan diarist and the eighteenth-century spiritual autobiographer share this inheritance. William Spengemann, in turn, explains that historical autobiography "was invented to demonstrate the consonance of an individual life with an absolute, eternal law already in force and known through some immediate source outside the life that illustrates it" (Forms $60) .{ }^{28}$ The notion of writing as an act of connection to an "eternal law" reassures the author and condones self-expression.

When the author of the first-person narrative no longer fears accusations of self-promotion and connects the self to a larger social structure, the autobiographical text speaks to both an internal and external audience. ${ }^{29}$ The eighteenth-century autobiographical narratives in this study illustrate this balance. The rise of diary keeping in the eighteenth century also suggests an appreciation for individual perspective, which Felicity Nussbaum has attributed to an increasing "privatization of self" that encourages "individuals with secrets to tell, especially women and dissenters" ("Toward" 134). Rita Felski also acknowledges that "the enormous production of first-person narratives during [the eighteenth century] bore witness to an intense interest in questions of personal feeling and the experiences of the ordinary individual" (101). As an important link to the autobiography, the diary contributes to self-construction as both a recipient of confessions and a vehicle for dreams while acting as an empty stage for new perceptions. The author can then rehearse these ideas and, if satisfactory, act them out in public. Where the Puritan diary reinforces social norms that set standards for self-monitoring, the eighteenth-century autobiography encourages personal reflection that distinguishes the author's perspective. This transition from public to private writing parallels a growing autonomy of self. ${ }^{30}$

\section{From Self-Examination to Self-Construction}

Following larger secular influences, the eighteenth-century first-person narrative undergoes a kind of "Copernican shift" which redefines the focus of the text. The seventeenth-century journal or diary places the author at the center of the text with the understanding that the individual is subordinate to the hierarchical powers of divine will and civil law. The eighteenth-century autobiographer who has witnessed cultural and political revolution can more 
easily occupy the center of the text without apology. ${ }^{31}$ The first-person narrative thus builds upon its self-examined impulses to generate new possibilities for taking up the autobiographical voice.

Benjamin Franklin's Autobiography provides perhaps the most flamboyant example of this new positioning of self. For Franklin, self-examination can enhance self-control as illustrated in his "arduous Project of arriving at moral Perfection" (66). He explains: "I enter'd upon the Execution of the Plan for Self-examination, and continu'd it with occasional Intermissions for some time. I was surpris'd to find myself so much fuller of Faults than I had imagined, but I had the Satisfaction of seeing them diminish" (71). ${ }^{32}$ By exposing his faults and attempting their eradication, Franklin transforms the practice of self-examination into a vehicle for self-construction. ${ }^{33}$ In the opening paragraph, in which Franklin views his life as a text subject to revision, he admits to these speculations:

... I should have no Objection to a Repetition of the same Life from its Beginning, only asking the Advantage Authors have in a second Edition to correct some Faults of the first. So would I if I might, besides correcting the Faults, change some sinister Accidents and Events of it for others more favorable, but tho' this were denied, I should still accept the Offer. However, since such a Repetition is not to be expected, the Thing most like living one's Life over again, seems to be a Recollection of that Life; and to make that Recollection as durable as possible, the putting it down in Writing. (1)

The proposition of a second edition leaves Franklin playfully philosophical, and the notion that alteration is possible inspires his autobiographical voice to recreate his story with an intriguing mix of subjective objectivity. Under Franklin's influence, the act of self-examination is transformed and literally revised. Franklin's own life (1706-90) marks the transition from a colonial to a postcolonial America, and it follows that his autobiography reflects the larger social shift from a colonial's servitude to a citizen's independence. Franklin's Autobiography is even more remarkable in that it was written over two decades and still attempts a sense of coherence. ${ }^{34}$

This text serves as a guide for self-examination and invites the reader to witness how Franklin's investigations lead to trials, errors, and success. The text retains its legitimacy by providing tangible evidence of achievement while admitting to doubt and frustration. Franklin refigures the spiritual autobiography into a more secularized text by making his goal individual improvement rather than spiritual affirmation. When Franklin refers to the "errata" of his life, this publishing term underscores that this text represents an editing of his life, and so he enumerates his various mistakes: taking advantage of his brother's imprisonment to assert his freedom and thereby disregarding his indenture; breaking into Vernon's money and thereby not honoring his responsibility as a messenger; not writing to Miss Read for over a year 
and thereby leaving her to marry another man. In each incident, Franklin recognizes that his life is in fluid state of self-examination.

Franklin's self-conscious and theatrical presentation of self distances him from the Puritan diarist worried about election and the afterlife. Instead, he internalizes the authority that permits him to tell the story of his life inspired by fortuitous economic opportunities and social reform. ${ }^{35}$ Franklin's self-editing thus departs from a Winthrop or a Bradford journal, which would certainly have given all editorial credit to God. His humble entry into Philadelphia and his later recasting of himself as a semimythical figure suggest Franklin's keen sense of self-construction:

I was in my working Dress, my best Clothes being to come round by Sea. I was dirty from my Journey; my Pockets were stuff'd out with Shirts and Stockings; I knew no Soul, nor where to look for Lodging. I was fatigu'd with Travelling, Rowing and Want of Rest. I was very hungry.... Then I walk'd up the Street, gazing about, till near the Market House I met a Boy with Bread. . . I bad him give three pennyworth of any sort. He gave me accordingly three great Puffy Rolls. I was surpris'd at the Quantity, but took it, and having no Room in my Pockets, walk'd off, with a Roll under each Arm, and eating the other. (20)

The passage, addressed to his son, William, expresses Franklin's pride in having come so far from so little as he carefully draws the scene by marking every sign of simplicity from his "working Dress" to his modest anonymity and satisfaction with his simple meal. This 1721 scene begins with his own dramatic preface to alert his son about the pending importance of this image: "I have been the more particular in this Description of my Journey, and shall be so of my first Entry into that City, that you may in your Mind compare such unlikely Beginnings with the Figure I have since made there" (20). Eight years later, in 1729, Franklin revisits this city and describes the expanding urban scene where "old Houses [were] inhabited, and many new ones building," and he references the changes with the time when he "first walk' $\mathrm{d}$ about the Streets of Philadelphia, eating [his] Roll" (53). Franklin collapses the initial scene into a kind of shorthand "eating my Roll" to represent the larger success story of the "self-made individual." In so doing, Franklin presents his life as a "work in progress" and promotes a more independent sense of self.

His plan for self-improvement addresses a larger debate over the source of one's virtue: Is virtue a natural trait or a class-determined quality? Is one born with innate virtue, or can it be developed and acquired? Virtue as a cultivated and not inborn trait gives further support to the application of selfexamination as a means of self-improvement or self-construction. When character is conceived as a consciously formed entity, it reflects the individual's confidence in being able to "grow into" oneself even though the exterior may or may not be consonant with the interior. The construction of character is further reinforced by popular courtesy books which provide instruction as to 
proper manners and dress and whose overall message is that character can be developed and acquired. While such instructions may appear to promote affectation to a modern reader, an eighteenth-century sensibility might argue that content can grow into its proposed form. Franklin's program for selfimprovement, for example, first acknowledges his shortcomings and then proceeds to correct them. He practices appearing "good" while eradicating bad habits. Good habits might then overcome bad inclinations as the reality of one's character rises to match its appearance. He acts upon the assumption that faults as well as character can be acquired and corrected, and his plan for "moral perfection" reaffirms this possibility. ${ }^{36}$ This eighteenth-century concern for virtue, moreover, offers a useful comparison to the seventeenth-century Puritan's concern with salvation. But whereas the latter may be beyond the individual's control, one's virtue may have some hope for reform. ${ }^{37}$

Construction of character coincides naturally with the larger debate of gaining independence from England. If an individual can transcend restrictions determined by birth, such as social position, by engaging in self-construction, a colony can overcome political oppression by asserting its own independence. And where Oliver Wendell Holmes considers Emerson's "American Scholar" America's intellectual declaration of independence, Franklin's Autobiography can be seen as a psychological declaration of independence. His deliberate act of self-mastery guides his reader through the streets of Philadelphia searching for his destiny, a simple gesture which holds far more promise for social mobility than it could have on the Continent or in England, where class structures were more codified. When Franklin uses self-examination for his self-editing, he sets the stage for Emerson, in "SelfReliance," to claim that "[n]othing is at last sacred but the integrity of your own mind." In Franklin's time, the first-person narrative seeks an amicable balance between self-expression and self-promotion. ${ }^{38}$

Following the empirical viewpoint wherein all phenomena is subject to investigation, Franklin finds the self a most worthy subject. The Autobiography is a virtual guide in self-construction, allowing the reader to learn from Franklin's mistakes and become inspired by his attempts to correct them. It is fitting that Franklin embodies the image of the "self-made individual"; his text blueprints this process and brings the genre of autobiography closer to the act of self-construction. His Autobiography thus serves as a model for ways of talking about the self in the six narratives chosen for this study and marks the apotheosis of the development of subjectivity in eighteenth-century autobiography.

From the self-examination of the spiritual diary to the self-construction of the secular autobiography, this book charts an increasing subjectivity in firstperson narratives. The autobiographical voice grows articulate as individual authority develops. No exact correlation between philosophical movements and individual action can be reasonably made, for such relationships are not 
easily measured. Instead, I consider these narratives valuable for what they suggest about habits of thoughts and for their strong assertions of self which demonstrate a confidence in first-person observation that distinguishes them from seventeenth-century journals and diaries. This overall development of subjectivity is a central focus of this study. Writing the self is guided by cultural principles; subjectivity makes possible self-construction.

In the Puritan diary the self is a reflection of social norms, an object to be studied and observed. In the eighteenth century, where the first-person narrative reflects new empirical interests, the self is valued more for its own observations, responses, and interpretations. Compared to more modern expectations of how much one should disclose of the inner self in an autobiographical text, the eighteenth-century autobiography may seem superficial. Yet when compared to seventeenth-century first-person narratives, these writings display a growing appreciation for individual subjectivity. Instead of simply making daily entries of outward activities or spiritual matters, the eighteenth-century narrator begins to piece events together and evaluate them in a more subjective weave that charts individual perspective. And, in the nineteenth century, the westward pioneer might keep a journal to fill a void from personal relationships left behind, granting it the role of both confessor and confidant. From the Puritan's diary to the pioneer's journal, the focus of the first-person narrator shifts from a public to a private arena. With the self-as-subject, the Romantics imbue the autobiography with a self-consciously introspective air. The eighteenth-century autobiography, by contrast, displays a refreshing lack of self-indulgence. For this autobiographer, the shift from royal subject to independent citizen reinforces individual authority. Inspired by democratic influences, the first-person narrative is gradually transformed from serving as a vehicle for self-examination to providing a platform for declarations of self. 


\section{Chapter 2}

\section{Declaring the Self in the Spiritual Sphere: Elizabeth Ashbridge and Jonathan Edwards}

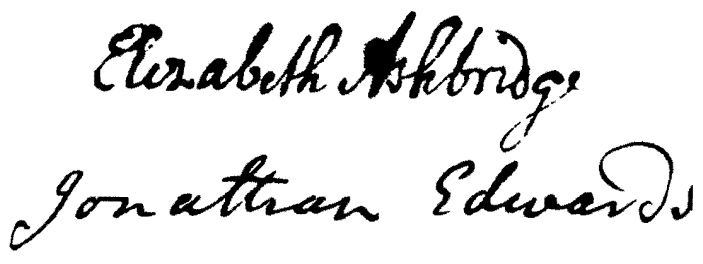

Reconstructing one's life prompts the autobiographer to suggest a certain overall plan or direction to this life. When this retelling is inspired by religious conversion, the author's secular life is recast within a newfound spiritual context to demonstrate how random events are part of a divine plan. The conversion experience initiates a revision of one's life whereby seemingly fragmented episodes suddenly assume a coherent narrative that finds the pilgrim emerging from a state of darkness, or spiritual ignorance, into a state of spiritual enlightenment. And unlike the secular autobiographer, who might claim credit for personal achievement, the spiritual autobiographer emphasizes the superiority of divine will over human willfulness. ${ }^{1}$ Thus even though

Fig. 1. The only known sample of Elizabeth Ashbridge's handwriting and signature appears here from an epistle dated "the 16th day of the 3 month 1752." Society of Friends. London Yearly Meeting. [Epistles received.] Epistle 1752 March 16 to London. From the General Spring Meeting of Ministers and Elders in Philadelphia. Enlargement of the reverse side of the epistle showing some of the signatures. Source: Manuscript collections (Gibson Mss vol. 3/75 [MS VOL 336]). Negative no. 87/ N 80. Reproduced with permission of the Library Committee of the Religious Society of Friends in Britain. Fig. 2. Jonathan Edwards's signature from a letter to Joseph Bellamy, 1747 June 11, Gen MSS 151. Reproduced by permission of Beinecke Rare Book and Manuscript Library, Yale University. 
autobiography is a deliberate construction of self and has even been called a "creation myth written in the first person, ${ }^{2}$ the spiritual autobiographer does not indulge in first-person narrative as a means of self-promotion but, instead, employs this form to reevaluate his or her relationship with Divinity. ${ }^{3}$ The conversion narrative is often dramatic, casting events and characters onto an exaggerated stage that contrasts a life before and after the transformation. In the eighteenth-century spiritual autobiographies of Jonathan Edwards and Elizabeth Sampson Ashbridge, conversion both challenges and inspires their faith. For the Puritan, Jonathan Edwards, the conversion experience affirms his religious commitment as a member of the elect. For the Quaker, Elizabeth Ashbridge, conversion allows her to break through doubt and embrace her true religion. Within this larger study of first-person narratives, the spiritual autobiography serves as the initial link from the practice of seventeenth-century self-examination to the act of eighteenth-century self-construction.

\section{The Implications of Gender in the Spiritual Autobiography: Individual Authority and Perceptions of Divinity}

The eighteenth-century attitude that character is a constructed image enhances subjectivity in the spiritual autobiography. If character can be cultivated and is not merely dictated from birth, so that nurture dominates nature, individual perspective gains credibility in all aspects of inquiry, secular and religious. The rise of evangelicalism complements this perspective by encouraging personal revelations and recognizing the individual church member as an important force in the congregation. The conversion experience has always been both a private and a public affair in that the community validates the individual experience. ${ }^{4}$ The evangelical movement builds on this relationship by eliciting more individualistic expressions of the experience itself. The Edwards and Ashbridge narratives, both written in the 1740s during the renewed religious fervor in colonial America known as the Great Awakening, ${ }^{5}$ demonstrate personal response through a more prominent sense of the individual voice. ${ }^{6}$ Within this context, these narratives challenge earlier texts, such as St. Augustine's, in which "self-analysis is valued not for its own sake but as a means of exposing the fallibility of humanity and affirming the ultimate authority of a divine knowledge beyond the individual's grasp" (Felski 103). By bringing this "ultimate authority" to a personal level, Edwards and Ashbridge contradict this view. It is precisely because of their self-analysis that their spiritual autobiographies explore their personal relationships with Divinity.

Individual analysis is further supported by the Enlightenment's privileging of experiential knowledge, which encourages investigation of all matters, secular and divine. Gordon Wood points out that even God's authority "was not immune to challenge. In an enlightened age God could no longer be absolute and arbitrary" (158). This perspective may be less applicable to 
Edwards's Puritanism than it is to Ashbridge's Quakerism, but in each text, their depictions of Divinity as a stern yet sympathetic figure render God more approachable. Writing about the self ị this investigative age enhances spiritual understanding and encourages subjectivity.

The congregationalist movement empowers the individual's voice by granting each member more say in church matters. The female's voice gains particular attention as she actively participates in the administration of the congregation. Although men generally hold leadership positions, women expand their roles beyond their expected demonstrations of piety. Amanda Porterfield considers the religious arena a means for "attaining status and exercising influence in a culture that prized humility." Following this model, submissiveness was not necessarily a sign of weakness but rather a "highly self-restrained and indirect means of exercising authority" (87). ${ }^{7}$ Self-examination provides the female with a sanctioned privacy, which allows for selfdirected thought and prayer. Spiritual identity thus expands the woman's otherwise limited sphere of authority. Laurel Thatcher Ulrich, for example, notes that within ministerial literature "women became legitimately visible in only three ways: they married, they gave birth, they died. In the written materials, dying is by far the best documented activity" ("Virtuous" 69). Despite this lack of attention, Ulrich notes that "[c]hurch membership was one of the few public distinctions available to women" (Good Wives 216). Nancy Cott elaborates on this argument, claiming that within Puritanism, "religious identity also allowed women to assert themselves, both in private and in public ways. ... to rely on an authority beyond the world of men" (140). ${ }^{8}$ And although this privacy is carefully circumscribed and the boundaries are clearly drawn, as the case against Anne Hutchinson confirms, the practice of self-examination itself can potentially encourage the female seeker. ${ }^{9}$ When compared to a previous generation's social codes, moreover, the Great Awakening encourages each gender's individual response. Women can claim the sphere of personal contemplation through religious practice without drawing criticism for neglecting domestic responsibilities. ${ }^{10}$ Men are free to explore doctrinal variations and establish new denominations. ${ }^{11}$

The woman's spiritual autobiography is of ten located in her domestic world, and thus it integrates personal, familial concerns more fully into the narrative than the male's. From a congregational perspective, the woman's domestic base as spiritual center is not necessarily a hindrance, as it too favors a more localized administration. The eighteenth-century spiritual autobiography, in fact, encourages her to draw upon her domestic identity to empower her spiritual voice. ${ }^{12}$ So where the female is more domestically bound, and therefore less likely to have the luxury of retreat, she refigures the domestic sphere as a source of spiritual guidance and strength.

Although such gender-based differences separate Edwards and Ashbridge in terms of their public authority, their conversion experiences share common ground. In both accounts, they trace a spiritual path subject to perpetual 
self-examination, and they each acknowledge their spiritual transgressions and praise spiritual conversion for keeping them from what Edwards calls "the ways of sin." With these strategies in mind, Elizabeth Ashbridge begins Some Account of the Fore Part of the Life of Elizabeth Ashbridge ... Written by her own Hand many years ago: "My Life being attended with many uncommon Occurences, some of which I through disobedience brought upon myself, and others I believe were for my Good, I therefore thought proper to make some remarks on the Dealings of Divine Goodness to me ... and most earnestly I desire that whosoever reads the following lines, may take warning and shun the Evils that I have thro' the Deceitfulness of Satan been drawn into" (147) ${ }^{13}$ In admitting her own "disobedience" as both self-inflicted and divinely orchestrated, Ashbridge's text can serve a larger didactic purpose. Hope comes for those readers who are similarly strong-willed and who also "earnestly" desire guidance to overcome demonic forces. From this gesture of self-disclosure, Ashbridge's "uncommon" life unfolds.

Edwards's self-examination is conducted within a more traditional, nondomestic structure and takes on its own confessional voice inspired by the enthusiasm of the Great Awakening. In the Personal Narrative, ${ }^{14}$ Edwards's self-reflections express a vulnerability willing to admit transgressions as he retraces his spiritual path: "I had a variety of concerns and exercises about my soul, from my childhood; but I had two more remarkable seasons of awakening, before I met with that change, by which I was brought to those new dispositions, and that new sense of things, that I have since had. The first time was when I was a boy, some years before I went to college, at a time of remarkable awakening in my father's congregation. I was then very much affected for many months, and concerned about the things of religion, and my soul's salvation ..." (81) ${ }^{15}$ Edwards asserts the " $\mathrm{I}$ " within the spiritual realms in an attitude of repentance and exemplifies the narrative as a vehicle for selfunderstanding and a guide to spiritual reflection. Edwards introduces himself as a sensitive, thoughtful child whose spiritual state is a primary concern and uses an earthly, cyclicalimage, "seasons of awakening," to mark the stages of his spiritual development, which suggest a New Testament sense of renewal through faith. ${ }^{16}$ Edwards places his revelations within the context of both his father's congregation and God's graces, which provide familiar, supportive surroundings for self-examination. This privileged social position lends his autobiographical voice an inherent authority. Above all, the Narrative marks his commitment to his spiritual salvation.

Each author thus affirms belief in a higher will and places his or her personal struggles within a larger context of fulfilling God's plan. In different ways, Ashbridge and Edwards are subject to regulation of the spiritual journey. Ashbridge must comply to social expectations as daughter, servant, and wife. As a minister, Edwards is beholden to public approval. For each, private contemplation reinforces community strength, especially in the congregational culture, in which, as Daniel Walker Howe explains, "society was ide- 
ally an organic whole, in which persons treated each other as fellow members of the body of Christ" (87). Given their common ground, Edwards and Ashbridge are each influenced by cultural expectations and each answers to divine law: Ashbridge must appease husband, family and God; Edwards answers to his congregation and to God.

Although their spiritual paths share common goals, their differences are marked primarily by their social positions as dictated by gender and class. Where Edwards is surrounded by encouraging role models, Ashbridge must construct her support system and explore her spiritual landscape alone, for as she narrates, "As I grew up, I took notice there were several different religious societies, wherefore I often went alone and wept; with desires that I might be directed to the right" (148). Contemplation is usually a private act, and seeking a spiritual community on her own signals both her autonomy and her isolation. Ashbridge thus introduces herself as an earnest, solitary seeker. ${ }^{17}$ Upon arrival in colonial America from Ireland, she again seeks direction and finds the search difficult: "I used to Converse with People of all societies as Opportunity offer'd \& like many others had got a Pretty Deal of Head Knowledge, \& Several Societies thought me of their Opinions severally; But I joyned Strictly with none, resolving never to leave Searching till I had found the truth" (155). In her distinction between "Head Knowledge" and "truth," she indicates that she will not be persuaded by dogma alone, a difficult task considering the enthusiasm of the Great Awakening. And in noting her desire for "truth," Ashbridge uses a Quaker term which refers to an inner revelation directed by spirit. By doing so, she foreshadows her Quaker beliefs and marks "truth" as a key to inner knowledge. Ashbridge thus constructs the autobiography to underscore the suspense of her story, wherein a solitary, female seeker who is reticent to join a false society will be guided to the truth.

Another gender-based difference in their narratives derives from their identification with God as the Divine Father. In that Divinity is often perceived as a paternal figure in the Judeo-Christian tradition, the seeker's relationship to this figure is affected by his or her relationship to the father. And even though the male may identify with divine power more easily through the Christ image ${ }^{18}$ each gender to some extent bows to a higher authority as an obedient child complying to the Father's wishes. From the smallest social unit, the family, to the larger spiritual unit, the church, a father rules over a membership, and a father doles out judgment. ${ }^{19}$ Divinity is subsequently imagined and portrayed in various forms ranging from legalistic portraits of a condemning God to a more forgiving, sympathetic figure. As eighteenth-century spiritual autobiographers who express their subservience in individuated voices, Edwards and Ashbridge honor Divinity while refiguring the more fearful aspects. True to the emotionalism of the Great Awakening, their conversions are ultimately inspired by a compassionate God.

Considering how theological images mirror paternal models, the female 
aspirant must readjust her relationship to this image in ways that her male counterpart may not. When she looks toward this image, the female seeker is confronted by expectations of her submission to male authority. For the male aspirant, such subordination is never as absolute, as he can still imagine himself in some form of authority in worldly affairs. Where Edwards assumes the lineage of a male tradition, Ashbridge seeks permission from the male authority figures in her life: her father, master, and husband. ${ }^{20}$ Edwards impressively expands his ministry, but it is Ashbridge who offers a new template for female spiritual authority.

In Ashbridge's initial desire to become closer to God, she longs to be more in his image. At one point, she identifies so closely with the male that she regrets her own femaleness: "In my very Infancy, I had an awful regard for religion \& a great love for religious people, particularly the Ministers, and sometimes wept with Sorrow, that I was not a boy that I might have been one; believing them all Good Men \& so beloved of God" (148). Finding her female status a barrier, Ashbridge imagines that becoming a boy would enhance her spirituality. Eventually, Quakerism will fulfill her spiritual desire by allowing her to transfer her identification from a male-identified spiritual authority to a female one.

Edwards also shares his spiritual anxieties, but they are never drawn within the same sense of alienation; instead, his fears are expressed within the support of his male community. When he speaks of his first "awakening," it occurs in his "father's congregation," and when he grows "concerned about the things of religion," he is able to "spend much time in religious conversation with other boys" (81). His doubts and his joys occur in a more inviting, selfimposed solitude, as when he writes of "sweetly conversing with Christ, and wrapt and swallowed up in God" (84). Within this private sphere, he is inspired, and unlike Ashbridge, he has the added pleasure of sharing his experiences with his father: "I gave an account to my father of some things that had passed in my mind. I was pretty much affected by the discourse we had together ..." (84). Edwards's meditations are thus validated by his community as he anticipates his pending ministry. Within this ongoing process of preparation, his spiritual path is carefully directed, and yet, as a Calvinist who never assumes his own worthiness, his obstacles are more internal than external: "I used to be continually examining myself, and studying and contriving for likely ways and means, how I should live holily, with far greater diligence and earnestness, than ever I pursued any thing in my life ..." (86). Clearly there is more public pressure for Edwards, who must justify his position to God, his congregation, and himself. Given this capacity for self-criticism, his narrative demonstrates how self-examination forges spiritual rebirth. He concludes this statement with an admission that he pursued his examination "with too great a dependence on [his] own strength; which afterwards proved a great damage to [him]" (86). Edwards may be able to model his spiritual life upon male images of Divinity, but he must also avoid the tempta- 
tions of adopting a "proud and self-righteous spirit" (95). The danger of too much self-authority keeps Edwards in line. He seeks an intimate, compassionate relationship with God that will guide and inspire.

Even within these Calvinistic restrictions on individual authority, Edwards can draw comparisons to the Divine Legislator in almost administrative ways that enhances his sense of authority. In one passage, he describes walking along the Hudson River with a Mr. Smith and explains how their conversations "used to turn much on the advancement of Christ's kingdom in the world, and the glorious things that God would accomplish for his church in the latter days" (88-89). Edwards is not, of course, presenting himself as God's equal, yet the comfortable manner in which these conversations take place suggests a contrast to a female Puritan, who might feel inspired but not instrumental in advancing such divine causes. As he watches over his own congregation, Edwards can more easily imagine himself as a student of Christ's. By contrast, the woman simply can not imagine herself directly in Christ's image, a barrier that limits her sense of authority.

For both genders, the image of the patriarch embodies mastery, and in each text the authors are interested in the self-improvement that comes from selfexamination. Although Ashbridge initially judges herself against the pending approval and disapproval of male authority, she will forge a new spiritual self with a distinctively female identity. Where Ashbridge battles, Edwards is supported. Solitude is encouraged in Edwards's life, but Ashbridge must construct her own sanctuary. Edwards grows into his position of authority; Ashbridge recognizes her limitations ${ }^{21}$ These two narratives are not meant to represent all conversion narratives, nor are they presented here to epitomize the male or female account. Instead, the gender issues are raised as another way to understand the complicated act of surrender within a narrative that values individual experience. ${ }^{22}$ For each author, the spiritual autobiography legitimizes subjectivity in the name of self-examination and develops self-awareness.

\section{The Female's Quest: Literary Sources and Spiritual Guides}

In Elizabeth Ashbridge's text, spiritual authority develops from confrontation and crisis, making hers the more flamboyant narrative. Although this style might be closer to the sentimental novel than to the traditional spiritual autobiography, her text breaks new ground in showing us the possibilities for female authority within the spiritual realm where all individuals are subject to divine rule. Although her choices may be limited, Ashbridge asserts some control over her life and inadvertently sets herself upon the spiritual path. Spiritual questing thus provides a sanctioned opportunity to exercise change, and the spiritual autobiography allows her to recast the apparent chaos of her journey into a unified narrative.

Literary outlets for women in early America were generally limited to the 
spiritual realm through the journal or poem. It is provocative, then, to wonder if Ashbridge may have found inspiration in the captivity narrative, a genre of colonial Puritan literature wherein female authorship is acceptable. Similar to the captivity narrative, Ashbridge's account integrates spiritual dilemmas with the physical and emotional demands of an external journey. Consistent with both the spiritual autobiography and the captivity narrative, Ashbridge demonstrates how physical hardship can be transcended by calling for divine intervention. A century earlier, A True History of the Captivity and Restoration of Mrs. Mary Rowlandson (1675) testifies that a woman can survive the rigors of a wilderness captivity primarily because of her strong faith. Although the captivity narrative limited personal discourse to religious concerns, it elicits the female reader's identification with the narrator's ordeal, offering her a potential role model and prompting her to ask, What would I have done in a similar situation?

The captivity narrator adopts a carefully constructed tone that avoids selfpromotion by framing the experience within a spiritual context, one that dramatizes the need for reassurance and affirmation. Even when Rowlandson mourns her child's death, for example, she places her grief within the larger scriptural context. The captivity narrative also shows how self-examination provides strength while also reinforcing social conformity. ${ }^{23}$ Rowlandson's dramatic experiences parallel Ashbridge's story as she must also overcome external obstacles and remain committed to her faith. Ashbridge's transformation from servant to wife to minister proves as dramatic as Rowlandson's release from captivity. And although Ashbridge follows in this tradition of spiritual autobiography, her text represents a significant shift, for her secular life plays a much more prominent part in her narrative. Self-examination allows each author a sense of order and control over her inner struggles, and each narrative reinforces the power of divine will over self-will.

While the seventeenth-century captivity narrative may have inspired Ashbridge in her spiritual conflicts, the eighteenth-century sentimental novel may have provided secular guidance. Novels such as Samuel Richardson's Pamela or Clarissa, for instance, portray young heroines who attempt to break free from oppressive circumstances and challenge male authority. As these heroines' virtues are tested, the audience debates the right to individual choice. Jay Fliegelman finds Clarissa "a martyred heroine who had led a revolutionary cause" and Pamela more virtuous than Mr. B when she "refuses the overtures of her master and fails to be blackmailed into reciprocating with sexual favors" (Prodigals 89, 100) ${ }^{24}$ And while American society was certainly not completely egalitarian, one's choices seemed less determined by class structures than in England. Clarissa, for example, may not have suffered the degree of social condemnation in the more fluid colonial American society than she did in England. For both British and American females, the sentimental novel provides clear messages for the wayward female. For example, Susanna Rowson's Charlotte Temple and Mrs. Foster's The Coquette ask their audi- 
ences to ponder the alternatives to being seduced and abandoned if indeed a young woman should transgress the prescribed social roles of female sexuality. If such rules are transgressed, the woman would be accused of coquetry, whereas a man would garner the more exotic title of "rake," as his promiscuous actions are supposedly more understandable than the mistakes of a Charlotte Temple or an Eliza Wharton.

In this sentimental tradition, therefore, Ashbridge's Account echoes the passions of Clarissa Harlowe, who also disregards her father and confronts a seducer. The Account blends the drama of the novel with the humility of the confession as she relates her story with echoes of an Edenic fall from innocence brought on by her elopement: "From my Infancy till fourteen years of age I was as innocent as most Children, about which time my Sorrows began, and have continued for the most part of my lifeever since; by giving way to foolish passion, in Setting my affections on a young man who Courted me without my Parents' consent; till I consented, and with sorrow of Heart may say, I suffered myself to be carried off in the night" (148). Childlike innocence is corrupted by the "foolish passion" of young love as Ashbridge struggles with the powers of female sexuality that precipitate her banishment. Not unlike her fictional counterparts, Ashbridge follows her romantic urgings and is cast into exile.

The woman generally sees herself more as a consequence of action rather than as an agent in sentimental fiction. Similarly, Ashbridge portrays herself reacting to various events and authorities. To begin, her elopement alienates her father, and upon her husband's early death, she leaves England for Dublin to live with relatives, hoping that her absence will "regain [her] Father's Affection." But the reconciliation is thwarted, as her father "continued Inflexible, \& would not send for [her] again" (148). His disapproval is so potent that Ashbridge chooses to sail for America rather than face his condemnations: "My Father still keeping me at such a distance that I thought myself quite shut out of his Affections, I therefore Concluded since my Absence was so Agreeable, he should have it" (150). Exile from her parental home parallels her spiritual isolation, and her narrative becomes an attempted reconciliation between spiritual and secular forces. To initiate this process, this defiant young woman arrives in New York in "the 7 mo 1732 ... a Stranger in a Strange Land" (151). Instead of this act liberating her, Ashbridge confronts an even more threatening oppression as an indentured servant, an unfortunate compromise which she committed to unknowingly while on board the ship, for as she explains, "I soon agreed with [a Gentlewoman] for my passage \& being ignorant of the Nature of an Indenture soon became bound, tho' in a private manner, (for fear I should be found out) tho' this was repugnant to law" (150). Her choices may be limited, but the role of daughter or wife will soon seem preferable.

Despite her rebellion, Ashbridge survives the perils of servitude by establishing her own spiritual and ethical codes. From her initial state of spiritual 
depravity, Ashbridge questions the legitimacy of external authority, especially her master who "would seem to be a Very Religious Man, taking the Sacrament (so called) \& used to Pray every Night in his family." She then notes that "when his Prayer Book was Lost," he ceased to pray, which appears hypocritical. This man's dependence upon external religious props to validate his faith provokes further criticism: "The Afforesaid Difference was of Such a kind that it made me Sick of his Religion; for tho' I had but little my Self yet I had an Idea what sort of People they should be that were so" (152). By rejecting his religion, she favors a more internalized source of spirituality and begins to define her own religious preferences. Here, she does so in opposition to her master-a remarkable display of independent thought. This overlapping of past and present within the narrative illustrates how Ashbridge constructs the text to demonstrate the complexities of her approaching consciousness by using her current spiritual perspectives to evaluate her past experiences. Criticizing her master's dependence upon his prayer book prefigures her acceptance of a Quaker doctrine that divinity is experienced inwardly and is not subject to external proof. ${ }^{25}$ For now, she is responding intuitively to an inconsistency that undermines the master's authority, and following the sentimental style, the heroine has named her oppressor.

Ashbridge uses her first-person narrative to register her displeasure, but it is clear that she lacks authority to create change. Initially, she can only declare what she dislikes and has yet to define what she wants; at first, she rejects all religion and "was Ready to Conclude that there was no God" (152). From this flirtation with atheism, she begins to speculate that God is "a pure being" who would not bother to "hear the Prayers of Polluted Lips." Ashbridge as "narrator" then intrudes with this explanation: "But he that hath in an abundant manner shown mercy to me (as will be seen in the sequel) did not Long Suffer me to Doubt in this Matter, but in a moment, when my feet were near the Bottomless Pit, Pluckt me Back" (152). Noting her life's events in terms of a "sequel," the text's literary parallels are once again evident. This depiction of God as a more compassionate force allows the possibility of her salvation as she reluctantly takes up the spiritual path.

Along the way, Ashbridge is of ten harshly treated, and the narrative illustrates her vulnerability as both a woman and a seeker. One such incident echoes the master-servant scenario found in several popular novels of the time, such as Pamela. Ashbridge has been outlining the deterioration of her relationship with her master and admits that "[f]or a While at first [she] was Pretty well used," but then "the Scale turned" because of "a Difference" that passed between them. Upon declaring herself "Innocent," Ashbridge then catalogs the abuses of her "Inhuman" master: "He would not suffer me to have Clothes to be Decent in, having to go barefoot in his Service in the Snowey Weather \& the Meanest drudgery, wherein I Suffered the Utmost Hardship that my Body was able to Bear, which, with the afforesaid Troubles, had like to have been my Ruin to all Eternity had not Almighty God in Mercy Inter- 
posed" (152). Although the account never clearly identifies the specific nature of these transgressions, Ashbridge attributes her endurance and strength to divine assistance. This passage not only underscores the moral poverty of her master but also emphasizes Ashbridge's vulnerability. In keeping with the sentimental style, Ashbridge's ordeal informs and instructs her female audience on the dangers of such servitude. ${ }^{26}$ By transcending this experience and recreating it in the spiritual autobiography, Ashbridge reaffirms female strength in a genre that sanctions first-person narrative.

The spiritual autobiography also allows her to express doubts and share tribulations without appearing self-promoting, for as she relates a series of crisis, their resolution will signal that grace is working in her life. In so doing, she satisfies Nussbaum's definition of the conversion experience itself, wherein a "crisis brings transformation, a time when the individual becomes inevitably and incontrovertibly different from what s/he was" ("Heteroclites" 157). Before she can be transformed, Ashbridge must first overcome selfdoubt. At one point, when she finds herself ready to relinquish all hope and contemplates suicide, she hears a voice that warns "there is a Hell beyond the grave." Suddenly aware of the consequences of damnation if divine punishment does exist, Ashbridge transcends her situation by imagining a female guide as an alternative authority figure:

... I had a Dream, \& tho' some make a ridicule of Dreams, yet this seemed a significant one to me \& therefore shall mention it. I thought somebody knocked at the Door, by which when I had opened it there stood a Grave woman, holding in her right hand an oil lamp burning, who with a Solid Countenance fixed her Eyes upon me \& said-“I am sent to tell thee that If thou'l return to the Lord thy God, who hath Created thee, he will have mercy on thee, \& thy Lamp shall not be put out in obscure darkness;" upon which the Light flamed from the Lamp in an extraordinary Manner, \& She left me and I awoke. (153)

Despite a nod to those who would invalidate dreams, Ashbridge overcomes doubts and explores the dream's power. With its Quaker-speaking guide, this vision of a solemn "Grave woman" calling the wayward pilgrim out from obscure darkness and toward a flaming light represents the spiritual quest as a movement away from ignorance and toward enlightenment. In turn, this woman awakens Ashbridge with the directness of a flaming light-a symbol of spiritual enlightenment-and places her on the threshold of a spiritual gateway. Although Ashbridge cannot pass over it, bound as she is by her own struggles, her ability to conjure this image speaks to her desire to break free. Just as the male pilgrim envisions a "city upon a hill" and can imagine himself its legislator, Ashbridge illuminates her path with a lamp from her own subconscious. By allowing this dream-vision a place in the narrative, Ashbridge fills her spiritual autobiography with her own iconography. The 
dream marks a dramatic break in a narrative which has so far depicted Ashbridge steadily slipping into spiritual ruin.

This momentary vision fades, however, in keeping with the format of the spiritual autobiography, which alternates revelation with despair, and Ashbridge continues to test both her spiritual and secular worlds, for as she tells us, "But alas! I did not give up nor Comply with the heavenly Vision, as I think I may Call it" (153). Calling her dream a "heavenly Vision" illustrates how the Quakers "treated their dreams as divinely inspired visions and messages. ${ }^{\prime 27}$ While the dream may reinforce Ashbridge's good fortune, her rejection marks her resistance. It follows then that her opposition almost leads to another crisis, or "Snare" as she calls it. This was a brief consideration of an acting and singing career in New York, which she cannot go through with for fear of "what [her] Father would say" (153). Incapable of either following the dream or dishonoring her father, she decides to remain a servant rather than return home to the father who has now forgiven her: " $[\mathrm{M}] \mathrm{y}$ proud heart would not Consent to return in so mean a Condition; therefore I chose Bondage rather" (153). Again, her decisions identify some of the psychological barriers that Ashbridge must contest before she can begin to assert her own authority and embrace her spiritual path. Ultimately, her narrative introduces possibilities for female authors who will eventually transcend such limitations and write of their own female quests. ${ }^{28}$ Until that time, a woman must negotiate within a power structure that assumes her subordination and resists her independence. Although the spiritual realm provides more chances for female leadership than the social sphere, the female aspirant of the eighteenth century is still beholden to the overriding expectations of social custom.

Amidst the spiritual autobiography's depiction of its author's struggles toward conversion, the narrative episodically charts numerous trails that test the aspirant's faith. For Ashbridge, the spiritual path is strewn with obstacles, and she must construct her own ethical codes as she struggles to overcome her own powerlessness. After confiding to another servant about their master's sexual advances two years earlier, for example, Ashbridge is called in to defend herself against a pending whipping. The master is clearly not interested in hearing Ashbridge's defense: "[He] ordered me to strip; at which my heart was ready to burst; for I could as freely have given up my Life as Suffer such Ignominy" (152). Despite her lowly status, however, Ashbridge defies her master's authority and avoids his punishment. Casting herself as the suffering heroine whose virtue is tested by the morally corrupt master, Ashbridge affirms the higher code: "I then fixed my Eyes on the Barbarous man, \& in a flood of Tears said: 'Sir, if you have no Pity on me, yet for my Father's Sake spare me from this Shame (for before this time he had heard of my Father $\&$ C. several ways) \& if you think I deserve such punishment, do it your Self.' He then took a turn over the Room \& bid the Whipper go about his business, and I came off without a blow ..." (153). In what should have been a mo- 
ment of humiliation, Ashbridge neutralizes her master's power by evoking her father's authority as she casts her fixed eyes upon the "Barbarous man" and makes an emotional plea. Although his barbarity is clearly drawn, she is still at his mercy, much as the heroine of the sentimental novel whose sense of virtue may be superior to her transgressor's. In both situations, the woman is left with little negotiating power. Ashbridge's defiance is thus placed within a broader, moral context, for she could not have confronted him solely on the basis of her own authority. Instead, she evokes a higher force, her father's authority, and challenges this "Barbarous man" to carry out the whipping himself. The confrontation halts his designs, and Ashbridge's narrative provides her female audience with a guide for negotiating such oppression by neutralizing her master's power and protecting her virtue-two admirable achievements for any eighteenth-century heroine.

The parallels between the novel and the spiritual autobiography are further drawn by a new series of events whereby she eventually buys off the rest of her indenture and supports herself "handsomely" by her needle until she remarries, an event noted with certain regret: "I had got released from one cruel Servitude \& then not Contented got into another, and this for Life" (153-54). In equating marriage with servitude and reinforcing her depravity, Ashbridge portrays her life as increasingly oppressive, and after admitting this transgression, as she views it, she follows with this description of her husband, a man named Sullivan: "I married a young man that fell in Love with me for my Dancing, a Poor Motive for a man to Choose a Wife, or a Woman a Husband. But for my Part I fell in Love with nothing I saw in him" (154). While the frankness of her declaration lacks the passionate tone of earlier episodes, it carries a similar tone of desperation. The decision appears made out of an apathetic resignation, a condition in which the spiritually depraved dwell. The section ends with this final admission: "[I]t seems unaccountable that I who had refused several, both in this Country \& Ireland, at Last married a man I had no Value for. . I now saw my Self ruined" (154). This marriage choice only intensifies her depression. Not only is Sullivan without religion and prone to "the worst of Oaths" when drinking, but this union appears to be taking her "to destruction" unless she can "alter [her] Course of Life" (154).Ashbridge's external guides are few, and she has resisted the inner vision. To this point, her attention has been taken up by external affairs, and as she begins to embrace Quakerism, guidance will manifest in all aspects of her life.

\section{The Female's Quest: From Servitude to Surrender}

Spiritual and marital activities are not, however, mutually exclusive, and unlike Edwards's narrative, the secular world intrudes upon Ashbridge's spiritual quest, forcing her to choose between authorities rather than simply reaffirm her belief in God. From this perspective, Ashbridge explains the 
impossibility of setting her "Affections upon the Divine being \& not Love [her] husband," so to make amends, she explains: "I Daily Desired with Tears that my Affections might be in a right manner set upon my husband, and can say in a little time my Love was Sincere to him" (154). Although this marriage appears to be a move toward "destruction," she "resolved to do [her] Duty to God" and prays to become a better wife and aspirant. ${ }^{29}$ Notably, Edwards never appears to direct his prayers in a similar direction. Ashbridge, on the other hand, must establish her credibility within the domestic sphere before her spiritual search can resume. Her spiritual autobiography shows how Ashbridge is led to the Quakers, where she will be encouraged to follow an Inner Light, an apt symbol for the inherent subjectivity of her narrative. Through self-examination, Ashbridge will cultivate this light just as through self-reflection her narrative encourages her subjective voice.

Fortuitously, Quaker doctrine is grounded in William Penn's claim that "Sexes made no difference; since in Souls there is none: and they are the subjects of Friendship" (qtd. in Shea, "Introduction" 123). This premise renders it more responsive toward the needs of a female seeker such as Ashbridge who must reconcile domestic struggles with her spiritual longings. ${ }^{30}$ Indifference toward gender is also reinforced by doctrine that finds that once a person chooses to be "convinced" of the truth, each individual is a potential vehicle for this light. ${ }^{31}$ Daniel Shea explains that "the Quaker who felt himself prompted to speak in meeting did so, not as an individual subject to praise or blame, but as the medium of the Spirit" (Spiritual 12). This assertion that spirit holds no gendered preferences encourages women to become vehicles for spirit, and this emphasis upon truth as a guiding force expands the woman's role. Moreover, as the Quaker spiritual autobiography is only published upon one's death, the text is meant to be explicitly instructive. Ashbridge can thus speak beyond her time and potentially frame a shared female experience as a woman who navigates her domestic and spiritual worlds as she moves from servitude to surrender to ministry.

In her initial encounter with Quakerism, however, self-reliance proves too radical. Ashbridge goes to a Quaker meeting in Boston "not Expecting to find what [she] wanted, but out of Curiosity," and her curiosity is met by her incredulity as she describes her reaction: "[T]here was a Woman friend spoke, at which I was a Little surprised, for tho' I had heard of Women's preaching I had never heard one before. I looked on her with Pity for her Ignorance (as I thought) \& Contempt of her Practise, saying to myself, 'I am sure you are a fool, for if ever I should turn Quaker, which will never be, I would not be a preacher"' (155). Even though Ashbridge is willing to attend Quaker meetings and hear their doctrines, she cannot yet accept the gender-breaking role of this woman preacher. Instead, Ashbridge actually pities this woman, an act which, of course, adds to the suspense and drama of her narrative while marking the range of Ashbridge's personal transformation. When confronted by this woman, Ashbridge berates a potential self-mirror and resists acknowl- 
edging the female preacher's authority. In Ashbridge's inability to imagine female authority, her anger seems infused with fear as this woman threatens Ashbridge's assumptions of social conduct and position. Before she can acknowledge this woman's authority, Ashbridge must relinquish preconceptions of external authority, and, as her narrative will ultimately demonstrate, honor a higher authority.

The Quakers' inclusion of the female minister complicates Ashbridge's relationship to authority. Having rejected the guide of the dream-vision, Ashbridge cannot imagine the actual manifestation of female authority before her. The initial shock of seeing a female preacher is quickly allayed when a man, whom she "could better Bear," takes over. Ashbridge is calmed by this more traditional figure and comments, "He spoke well \& I thought raised sound Doctrine ..." (155). This response echoes her earlier admission that she "wept with sorrow" while wishing she could be a man and thus a minister. Quaker doctrine may allow Ashbridge to fulfill this desire to be a minister, but she must first transcend her resistance. The journal thus complies with the classic conversion structure of resistance followed by realization in which pride is the determining factor that keeps the pilgrim from spiritual enlightenment. The retelling enables her to see the providential design of her life, and the autobiographical narrative provides her with the appropriate ordering device.

Captive to her spiritual ignorance, Ashbridge is not fully convinced that the Quakers are her answer, but her husband's resistance fuels her spiritual quest as she heads off to visit relatives in Pennsylvania. As an instructive text, the spiritual autobiography is meant to illustrate an aspirant's ignorance, which willdramatize the eventual conversion and realization of spiritual truth. Appropriately, then, upon Ashbridge's arrival she has this hostile reaction: "I met with no small Mortification upon hearing that my Relations were Quakers, \& what was worst of all my Aunt a Preacher." Ashbridge is apparently willing to question some social institutions, such as her indictment of marriage, yet she hesitates to expand the boundaries of authority that would, again, allow her to accept a female preacher. Her hostility, however, is immediately tempered by the larger intentions of the narrative to illustrate how "God brings unforeseen things to Pass" (158). The narrative continues to weave its thread of text-as-symbol when Ashbridge inquisitively picks up her Aunt's book and proceeds to read "Saml. Crisp's Two Letters." She then stops after reading two pages because "Tears Issued from [her] Eyes." ${ }^{132}$ Fearing discovery, Ashbridge brings the book outside "into the garden, sat Down, and the piece being Small, read it through before [she] went in" (158-59). Emotionally charged, she continues reading, but "Some Times was forced to Stop to Vent [her] Tears, [her] heart as it were uttering these involuntary Expressions" (159). Ashbridge's reaction marks the intensity of her prejudice toward the Quakers and the power of the text to evoke such response. Even though her Aunt had warned her that "'Cousin that is a Quakers' Book, "' Ashbridge 
defies authority by reading, and yet, ultimately, she realizes, by "going there [she] was brought to [her] Knowledge of his Truth" (158).

Spiritual surrender requires an internalization of spiritual knowledge. In moving toward this state, Ashbridge remains highly sensitive to external representations. This incident, in turn, mirrors the earlier condemnation of her master's dependence upon his prayer book as a religious prop, for now when Ashbridge holds such a "prop," she attests to some force in this Quaker book wherein her burning heart and tearing eyes evoke an image of spiritual passion. Walking "into the garden" offers Ashbridge some relief as she surrounds herself with nature and surrenders more completely to the text and her emotions. Providence has ordained that she relinquish discrimination against the Quakers and begin the self-examining process that will lead to her conversion. This episode also parallels her dream in that here words are made more tangible and Ashbridge reacts to them in her waking life just as powerfully as when she was awakened by the grave woman holding the flaming light. In the dream, the passive Ashbridge can only listen; now, she actively gives voice to her spiritual questing.

Clearly, she is willing to sacrifice anything for the approval of Divinity, but Ashbridge is not entering the same subordinate state that she experienced as servant and wife; instead, as a Quaker, her relationship with Divinity will elevate rather than diminish her self-worth. The book, in turn, substitutes for the traditional male mentor as it allows Ashbridge to fashion an internalized authority that will lead to her spiritual reinvention. Kevin J. Hayes marks this scene as a reaffirmation of the "essentially private nature of devotional reading," which emphasizes the value of the spiritual sphere for contemplation (49). Unlike Edwards, Ashbridge lacks role models who can offer instruction in negotiating her spiritual path, and as she persists in selfquestioning, her doubt increases her isolation. Prior to her revelation in the garden, there were profound inner struggles. Ashbridge glimpses a vision of her own darkness while sitting by a fire on a stormy night surrounded by her husband and others:

... there arose a Thunder Gust, \& with the Noise that struck my Ear, a voice attended, even as the Sound of a mighty Trumpet, piercing thro' me with these words, "O! Eternity, Eternity, the Endless term of Long Eternity:" at which I was Exceedingly Surprized, sitting speechless as in a trance, and in a moment saw my Self in such a state as made me Despair of ever being in a happy one. I seemed to see a Long Roll wrote in Black Characters, at sight whereof I heard a Voice say to me, "this is thy Sins;" I then saw Sin to be Exceedingly Sinful.... (156)

Rapt in this view of two worlds, the awesome power of divine thunder and the distressing power of sin, Ashbridge's perceptions and sense of reality are challenged. This altered state goes unperceived by her company who think 
that her "[i]ndisposition proceeded only from a fright at the Thunder." And yet in this state of separation, she creates a sphere in which she reads the signs of nature, thunder, as a portent to her spiritual struggles. Although such readings are similar to Samuel Sewall's interpretations of natural phenomena, when Ashbridge sees the "Long Roll wrote in Black Characters," she decides that no matter how painful the struggle might become that she will alter this "fate." By contrast, Sewall may not have imagined this same assertion of individual direction. The scene leaves her profoundly changed, and "from that time for several months [she] was in utmost Despair." This disorientation ushers in a new phase of her transformation.

With renewed spiritual strength, Ashbridge continues to fight her domestic battles. Sullivan's displeasure increases, and Ashbridge moves further away from the original image of the dancing wife. Although she realizes how painful her radical change has been on her husband, she cannot alter her path: "My singing now was turned into mourning \& my Dancing into Lamentations: my Nights and Days were one Continual Scene of Sorrows ..." (156). More so than Edwards, Ashbridge dramatizes her situation in hopes of convincing a sympathetic audience that her commitment to spiritual salvation overrides her attempts to save a floundering marriage. The narrative's sentimental tone reinforces her anxiety as she adopts the voice of a struggling heroine. Ashbridge cannot assume the same level of authority as Edwards does in his text. The drama must then explain her self-assertion.

Confidence fluctuates, however, and Sullivan's desire that she fulfill her roles as entertainer and helpmate proves overwhelming. Ashbridge falls into a suicidal depression for the next two months wherein she is "Daily tempted to destroy [herself]." Only her surrender to divine will can alleviate this despair. As she lay awake beside her sleeping husband "bemoaning [her] Miserable Condition," she appeals to God, and finds immediate relief: "-In an Instant my heart was tendered, \& I dissolved in a flow of tears, abhorring my Past Offences, \& admiring the mercy of God" (157). She then looks upon Christ "with an Eye of Faith," and with new sight she writes, "[I] saw fulfilled what I believed when the Priest lent me his Book, (Viz.) that if ever my Prayers would be Acceptable I should be Enabled to pray without form \& so used form no more" (157). By aspiring to "pray without form," she begins to internalize her spiritual relationship. Criticism of external forms suggests Ashbridge's cynicism of a nonbeliever, and as she grows closer to Quaker doctrine, she will accept new forms, albeit more internalized ones. The autobiography is constructed after she has reconciled these external and internal manifestations of spirituality so that "external" forms of her belief are permissible once they are inspired by a valid "inner voice." The narrative's perspective is, of course, one of the convert who attempts to recapture the emotional state of the aspirant, and as with Franklin, Ashbridge's narrative construction of identity can potentially remake the self.

Ashbridge's spiritual struggles must certainly be placed against the larger 
social and religious backdrop of the evangelical excitement of the Great Awakening, for as she restructures her relationship with Divinity, she is encouraged by the emphasis upon more immediate and individual relationships with God. In forging this new bond, Ashbridge experiences a series of spiritual crisis which render her helpless in order to prepare her for the new, postconversion life. By embracing "formlessness," Ashbridge will then be encouraged to cultivate an inner guide which is ultimately more individualistic than either the Catholic or Protestant alternatives, especially for a woman. In her new state she "seemed Like another Creature, and of ten went alone withoutfear, \& tears abundantly flowed from [her] Eyes." Ashbridge relinquishes sterner, unapproachable images of Divinity and portrays a nurturing and merciful figure: "I heard a gracious Voice full of Love, saying, 'I will never Leave thee, nor forsake thee, only obey what I shall make known to thee.' I then entered Covenant saying: 'My soul Doth Magnify thee the God of mercy, if thou'l Vouchsafe thy Grace the rest of my Days shall be Devoted to thee, \& if it be thy Will that I beg my Bread, I'll be content and Submit to thy Providence" (158). With the voice of God perceived as a "voice full of Love," Ashbridge indicates a new confidence in her spiritual musings. Although she is inspired here, Ashbridge's spiritual rebirth is not instantaneous, for immediately after she feels drawn into a covenant with God, she writes of a sleepless night in which she encounters "the old Enemy." After raising doubt, this "Subtile Serpent transformed himself so hiddenly" that Ashbridge reverts to her earlier caution and tells us that she "so resolved to beware of the Deceiver, \& for Some weeks Did not touch any of their Books" (159). Resolving not to "touch any of their Books" implies that she will avoid the impact of their teachings as the temptations of the "Subtile Serpent" force her to construct her own internal sense of authority. Contrary to Edwards, Ashbridge cannot openly claim her spiritual authority. Instead, she allows external authorities-books, father, husbands, ministers-to influence her direction. The process of conversion allows her internal voice to take on external form, much as the spiritual autobiography provides the physical structure for her internal musings.

This spiritual autobiography is further distinguished by the dramatic presence of Ashbridge's husband as antagonist, who considers his wife's foray into Quakerism a sickness that needs immediate attention. Dismissing her faith as an external construction, Sullivan is convinced that geography somehow determines spirituality, and he orchestrates their sudden departure from Pennsylvania to Staten Island. He feels justified in his fight as his once cheerful wife continues to transform into a plain and somber Quaker, and so Ashbridge submissively writes, that the "time of Removal came, \& I must go" (162). Then, after traveling fifteen miles, Sullivan decides they are far enough away from Quaker influence and stops at a tavern where, in an apologetic tone, he explains to those present that his wife is a Quaker and that he sought a place "where there was none" (162). He then attempts to get his wife to dance and thereby reenter "normal" society. It is a tense scene that Ashbridge narrates: 
"He comes to me, takes me by the hand saying, 'come my Dear shake off that Gloom, \& let's have a civil Dance; you would now and then when you was a good Churchwoman, \& that's better than a Stiff Quaker.' I trembling desired to be Excused; but he Insisted on it, and knowing his Temper to be exceedingly Cholerick, durst not say much, yet did not Consent. He then pluk'd me round the Room till Tears affected my Eyes, at sight whereof the Musician Stopt and said, 'I'll play no more, Let your wife alone,' of which I was Glad" (162). Sullivan's reference to a "Stiff Quaker" and his angry manner in which he "pluk' $\mathrm{d}$ " Ashbridge round the room shows his utter frustration and suggests a rape of her will. The musician who "Stopt and said, 'I'll play no more, Let your wife alone,'" counteracts this force and, although Ashbridge is still being saved by a man, she wins this battle by remaining true to her beliefs. Sullivan's desire for conformity contrasts Ashbridge's desires for spiritual truth.

Faced with Sullivan's persistent disapproval, Ashbridge finds herself in danger of aborting her quest altogether and succumbing to an unhappy marriage. When someone offers to "cure her of her Quakerism" by giving both she and Sullivan teaching positions in Freehold, East Jersey, this new development has an unexpected effect by inspiring Ashbridge to assert her will more fully. Consequently, Sullivan becomes even more aggressive and brandishes a pen knife, threatening, "'[I]f you offer to go to Meeting tomorrow, with this knife I'll cripple you, for you shall not be a Quaker"' (166). Despite Sullivan's protestations, however, he gradually acquiesces to his wife's determination: "One day he said, 'I'd go to Meeting, only I am afraid I shall hear you Clack, which I cannot bear." ${ }^{\prime \prime}$ He then remarks, "I'll no Longer hinder thee'" (168). In granting his permission, Sullivan frees Ashbridge to assume a more active role in meetings. Although they stay together, they stand as opposites; Sullivan falls further into spiritual darkness while Ashbridge moves closer toward the light, which allows her to withstand her husband's threats, drinking, and beatings. In a rather perverse way, therefore, Sullivan hastens her spiritual search by providing such an unappealing alternative.

Sullivan's agreement not to "hinder" his wife's ministry is somewhat anticlimactic, for, soon after, Sullivan enlists "as a Common soldier to Cuba anno 1740," and goes off to fight in a war wherein he refuses to take up arms and is arrested. Ashbridge sincerely bemoans his situation and includes an extensive description of his final days, which she concludes with: "They used him with much Cruelty to make him yield but Could not, by means whereof he was So Disabled that the General sent him to the Hospital at Chelsea, where in Nine Months time he Died \& I hope made a Good End, for which I prayed both night \& Day, till I heard of his Death" (170). Refusing to fight, the oncecombative Sullivan seems to have resolved his battle with Quakerism by embracing pacifism. Upon acknowledging his death, Ashbridge writes that she is being prepared "for future Service" and having fulfilled her social duty as wife pursues her spiritual path with renewed intensity. ${ }^{33}$ 
Ashbridge's Account addresses the difficulties of a female spiritual quest complicated by paternal banishment, early widowhood, indentured servitude, and marriage. Embattled by men who try to repress her spirit, she remains steadfast in her quest and takes her place as a devoted follower after having challenged traditional notions of religious authority. The Account, rather traditionally, concludes with a final acknowledgment of God's power: "[M]ay thou O God be Glorifyed and I abased for it is thy own Works that praise thee, and of a Truth to the humble Soul that Makest every bitter thing Sweet.The End.- " (170). The tensions between an external and internal authority have been played out on several levels in Ashbridge's life until she ultimately triumphs as pilgrim and minister. Her narrative testifies to the difficulty of the female's spiritual path amidst social prejudice toward female authority. And in writing her narrative, Ashbridge demonstrates how self-examination encourages this authority.

\section{The Male's Quest: The Burden and Blessing of Spiritual Primogeniture}

The spiritual quest is designed to curtail personal inclinations for the glory of spiritual commitment. Jonathan Edwards must also contend with the added pressures of an inherited spiritual legacy. Within this study of the developing subjectivity of the first-person narrative, Edwards moves us into altogether new territory. For Edwards, the narrative's innovation is not so much in the claiming of a spiritual identity or authority as it is in the expression and quality of this identity. Edwards converses with Divinity in a confidential, sometimes poetic voice about his trials along the spiritual journey.

In contrast to Ashbridge's more earthbound narrative, which includes domestic and everyday affairs, Edwards's autobiography dwells on more abstract and idealized planes, and one feels that he is not quite a mortal human being but, rather, a representative, emblematic figure. When Edwards strolls in his "father's pasture, for contemplation" or walks along the Hudson River, these scenes reaffirm a spiritual primogeniture as Timothy Edwards mentors his son. The young Edwards is clearly supported on his ministerial path. These avenues are unavailable to Ashbridge, and what is expected for Edwards is denied to Ashbridge. The assumption that Edwards will carry on the tradition, however, poses different problems. Ashbridge may lack confidence, but Edwards must make sure that his advantages do not keep him from submitting to God's will. Coming to spiritual surrender from a place of potential authority appears to be just as problematic for Edwards, who writes of "violent inward struggles." And where Ashbridge indicates a greater concern for pleasing others, Edwards asserts himself more autonomously. The aspiring minister conveys a stronger sense that his actions will have some influential effect. ${ }^{34}$

Even though Edwards projects self-confidence, his Narrative catalogs his 
numerous conflicts and doubts. During his final year at Yale, for example, Edwards experiences this affliction: "[I]t pleased God, to seize me with a pleurisy; in which he brought me nigh to the grave, and shook me over the pit of hell" (82). Edwards had been in a "very uneasy" state about his spiritual health, and so as God seizes and shakes him, it forces him to confront his own doubts and once again face his own worthlessness. This foreboding figure stands in contrast with other images of a more forgiving God, suggesting salvation through the redemption of a New Testament God is preferable to the condemnations of an Old Testament figure. Owen Watkins, in turn, identifies a pattern to the spiritual autobiography in which "conviction of sin, followed sometimes sooner, sometimes later, by an experience of forgiveness" (9). Through various episodes, Edwards graphically illustrates these fluctuations.

Edwards's struggles are often internal, and conflict centers around doctrine, for to doubt is to question the very core of his Puritanism. Edwards tells us the worst episode yet when he recounts: "From my childhood up, my mind had been full of objections against the doctrine of God's sovereignty, in choosing whom he would to eternal life, and rejecting whom he pleased; leaving them eternally to perish, and be everlastingly tormented in hell. It used to appear like a horrible doctrine to $\mathrm{me}^{\text {" }}$ (83). To call divine sovereignty "horrible" is to question his own election. By challenging this fundamental belief, Edwards marks an important moment in the evolution of his faith. Before he surrenders to the ultimate will of divine power, he subjects this doctrine to his rational faculties. Edwards then recognizes that both reason and intuition inform his understanding of the doctrine of God's sovereignty. His understanding is ultimately a matter of faith: "But never could give an account, how, or by what means, I was convinced, not in the least imagining at the time, nor a long time after, that there was any extraordinary influence of God's Spirit in it; but only that now I saw further, and my reason apprehended the justice and reasonableness of it" (83). In reconciling his faith and reason, Edwards expresses humility without sacrificing individual expression. Although he questions, Edwards traces the process through which the doctrine eventually appears as "exceedingly pleasant, bright, and sweet," and he concludes with this dictum: "Absolute sovereignty is what I love to ascribe to God. But my first conviction was not so" (83). The assertion made, Edwards's narrative goes on to illustrate both his lingering rebellion and his eventual embrace of this doctrine. ${ }^{35}$

One manifestation of this struggle appears much later, when Edwards is a minister himself who preaches and abides by God's law. Although Edwards promoted and supported the Great Awakening's call to emotionalism, which encouraged individual responses to conversion, he was also subject to its challenges to the church's power structures. For example, in the Northampton Controversy in 1750, Edwards demanded that "all new communicants profess conversion" (Karlson and Crumpaker 13). Rather than comply, members 
questioned the omnipotence of such authority and voted to remove Edwards. True to the very goals that Edwards promoted, the dissolution of his ministry prompted a more direct relationship between the devout and the divine, demoting the minister's role as absolute mediator. Ironically, Edwards was cast out by the rise in individual involvement that he helped create. Although his particular circumstance may have been extreme, Edwards neither denied the power of enthusiasm nor advocated a return to more subdued times. Instead, he offered a moderate expression, one which Michael Gilmore calls "the middle way," that attempted to balance radical factions between the "legalism of the established clergy and the otherworldliness and spiritual pride of the Separate zealots" (Middle 4). Establishing this balance between individual and institutional authority was key for maintaining church stability. Edwards offers an unusual example of maintaining this equilibrium.

\section{The Male's Quest: From Battle to Surrender}

The public sphere may have ultimately been dissatisfying for Edwards, but as the Narrative frequently illustrates, solitude for spiritual contemplation is readily available. By assuming this privilege, Edwards can assert the " $\mathrm{I}$ " more definitively in his spiritual autobiography than the female, for he is less concerned with appeasing external authority or reinforcing servitude. Another manifestation of Edwards's independence is the confidence portrayed in his interactions with nature. As he walks along chanting his prayers, Edwards appears suspended in an almost romantic isolation as he brings the practice of self-examination out onto the colonial landscape. Edwards frequently places himself outside of the community for contemplation, which suggests a new relationship between individual and society. ${ }^{36}$ Benefiting from his ministerial heritage, Edwards draws on his solitude for self-examination and frames the pilgrim's quest as an intimate conversation with God as he strolls through pasture and forest. Spiritual contemplation can clearly take precedence over his domestic concerns in a manner unavailable to his female counterpart. His solitary walks, in turn, fall outside of the Augustinian tradition by not addressing a future recipient of his spiritual legacy. ${ }^{37}$ And where such removals would have been suspect to his seventeenth-century ancestors, they will seem commonplace to his nineteenth-century progeny. Edwards shows us where the personal narrative is going, for it will become an arena for philosophical and spiritual self-reflection as manifest in the Transcendentalists of the next century.

Edwards's romantic sense of his natural environment is the most distinguishing difference between the Ashbridge and the Edwards texts. In contrast to earlier, Puritan attitudes that nature was a force to be controlled or avoided, nature is of ten seen as a sympathetic presence in his narrative. When Jonathan Edwards takes his meditative walks through the woods, he replaces fearful images of nature as a foreboding wilderness with his "vision, or fixed ideas 
and imaginations, of being alone in the mountains, or some solitary wilderness, far from all mankind, sweetly conversing with Christ, and wrapt and swallowed up in God" (84). The witch-infested forests of Cotton Mather have become a contemplative landscape, and a fiery God has taken on a more compassionate nature. Although Ashbridge's text rarely ventures into Edwardslike pastures, she too uses the woods to vent her sorrows: "I used to Walk much alone in the Wood, where no Eye saw nor Ear heard, \& there Lament my miserable Condition, \& have often gone from Morning till Night and have not broke my Fast" (161). In each case, the woods are valued for their restorative powers, marking a departure from earlier visions of the "desolate and howling wilderness." This comforting image further suggests an increasing familiarity with the colonial landscape, which encourages a larger projection of the self onto this natural stage.

Nature and contemplation allow Edwards to fulfill his desire to be "far from all mankind." After reading from the "book of Canticles," Edwards writes of an "inward sweetness, that would carry me away, in my contemplations" (84). In his own willingness to be carried away, Edwards invites his congregation to experience being "wrapt and swallowed up in God" (84). ${ }^{38}$ Finding himself moved by his father's discourse, the young Jonathan Edwards walks "abroad alone, in a solitary place in [his] father's pasture, for contemplation." He then has this revelation: "[L]ooking upon the sky and clouds, there came into my mind, a sweet sense of the glorious majesty and grace of God, as I know not how to express.-I seemed to see them both in a sweet conjunction; majesty and meekness joined together: it was a sweet, and gentle, and holy mystery; and also a majestic meekness; an awful sweetness; a high, and great, and holy gentleness" (84-85). The sensual quality with its sweet and gentle images finds Edwards cradled in nature. His prose here certainly warrants Emory Elliott's description of Edwards as "an artist of language" ("New England Puritan" 301). In his pairing of polemical images, Edwards exaggerates the "sweet conjunction" of sensual elements that carry an "awful sweetness" which can either uplift or humble him. The alternate rhythm of these images suggests the regenerative, sexual potential of nature in which opposite energies move toward consummation. Edwards thus celebrates God's power by allowing himself to be immersed in the contemplative powers of nature.

It has always seemed curious that Edwards could author both the Personal Narrative and the prototypical fire and brimstone sermon, "Sinners in the Hands of An Angry God" (1741), curious because equally strong images of nature are used to create entirely different effects. The benevolent images of God and nature in the Personal Narrative are replaced by fear and damnation in "Sinners," which he delivered as a visiting minister in Enfield. Natural forces are associated with horrific images, such as the "lake of burning brimstone," as Edwards warns his congregation: "There are black clouds of God's wrath now hanging directly over your heads, full of the dreadful storm, 
and big with thunder; and were it not for the restraining hand of God, it would immediately burst forth upon you. The sovereign pleasure of God, for the present, stays his rough wind; otherwise it would come with fury, and your destruction would come like a whirlwind, and you would be like the chaff of the summer threshing floor" (158). This passage emphasizes the darker forces in a relentless catalog of the potential dread awaiting the unfaithful. God is filled with fury as the howling wilderness and Edenic garden collide, and Edwards reinforces traditional Calvinist images of a wrathful God and a fearful, submissive congregation as he urges public confessions of faith. In some ways, the contrast between these two works foreshadows the ranges of Romanticism, with its dark and light manifestations.

Where "Sinners" diminishes the individual's power, the Narrative encourages the individual's search for spiritual knowledge. Edwards muses upon his soul in a romantic style as he testifies that his "sense of divine things gradually increased, and became more and more lively and had more of that inward sweetness." In fact, Edwards's entire sensory field is transformed and the "appearance of every thing was altered." The interaction suggests that as Edwards is filled with God's beauty, everything around him becomes beautiful: "[T] here seemed to be, as it were, a calm, sweet, cast, or appearance of divine glory, in almost every thing. God's excellency, his wisdom, his purity and love, seemed to appear in every thing; in the sun, moon and stars; in the clouds and blue sky; in the grass, flowers, trees; in the water and all nature; which used greatly to fix my mind" (85). Edwards internalizes this power. His spiritual vision then illuminates and animates the physical world. For Edwards, conversion is an intensification of his innate spiritual sensibility. Edwards honors God's presence and feels profoundly connected to the whole of creation in this moment of surrender.

From these passages, the Narrative most fully anticipates Romantic associations between nature, contemplation, and Divinity. Ultimately, these associations will give the individual more confidence as nature supports spiritual growth and encourages self-reflection. Nature reveals a "glorious majesty" to Edwards, and he feels closer to God's graces. Majesty couples with meekness, and Edwards is inspired by an external world that nurtures his spiritual questing.

His predecessors would have considered Edwards's haunts a forbidden wilderness, and yet he feels uplifted rather than frightened. Edwards subsequently reinterprets nature. For, unlike Sewall who marks thunder and lightning as images of God's displeasure, Edwards claims that "I felt God, if I may so speak, at the first appearance of a thunderstorm ..." (85). God's power inspires Edwards to share in the glory and become uplifted. Delighting in this display, Edwards then explains how he "used to take the opportunity, at such times, to fix [himself] in order to view the clouds, and see the lightnings play, and hear the majestic and awful voice of God's thunder. ..." While enraptured by this view, Edwards would "sing, or chant forth [his] meditations; or, 
to speak [his] thoughts in soliloquies, with a singing voice" (85). This reaction complements God's power, and as Paul David Johnson sees it, "[Edwards's] singing re-creates the expansiveness of divine immensity within him and, in repetition, creates infinity" (279). Edwards is inspired by the forces of nature, and, unlike Sewall, he is not diminished by this power; instead, nature elevates and empowers him. In his willingness to embrace nature, Edwards alters his temporal relationship with his surroundings. His lyrical descriptions of forest and sky focus more upon the present moment. By slowing down the time frame and isolating the moment, Edwards marks time in a more personal way, exclusive of a larger social context. This gesture enables him to have more control over the moment, a quality that can potentially enhance his projection of self into the narrative.

Edwards's pose of the contemplative pilgrim surrounded by nature portrays an interactive relationship between the seeker, Divinity, and nature. His harmonious imagery mirrors his spiritual world and expands into his physical sphere, a privilege that Ashbridge the minister might have also enjoyed. Edwards brings the aspirant out on to the landscape and asserts the self in new ways through a most traditional form. Metaphorically, conversion is an affirmation of subjectivity; it is the individual's most personal articulation of spirituality.

The spiritual autobiographies of Elizabeth Ashbridge and Jonathan Edwards are written in a spiritually revolutionary time when authority is questioned and gender roles are challenged. Reaching toward synthesis of some kind, the gender roles represented in these narratives illustrate an attempt to integrate opposite poles. Edwards reveals a softer, contemplative voice, while Ashbridge speaks with conviction, declaring her spiritual quest valid and important. Daring to explore these realms, the consequences are often complicated. Edwards suffers a fall from church power, and Ashbridge must deal with an abusive husband. For each, the individual's responsibility is to balance faith in external authority, God, with trust in internal authority, an inner voice. Where Ashbridge is rescued, "Pluckt me Back," Edwards is potentially abandoned, "shook me over the pit of hell." In each case, these encounters cause them to renew their quests. Edwards strengthens his commitment: "My concern now wrought more, by inward struggles, and conflicts, and selfreflections. I made seeking my salvation, the main business of my life" (82); Ashbridge withstands her master and husband and embraces Divinity in preparation for the ministry: "which I did with all my whole heart \& hope ever shall while I have a being" (168). They present a more intimate relationship between aspirant and Divinity, which encourages individual emotional responses to spiritual matters.

This respect for the individual voice allows them to write about their spiritual paths with greater subjectivity. Edwards and Ashbridge acknowledge both personal and social authority within the religious sphere. The Transcenden- 
tal movement of the nineteenth century will build upon these individual responses to Divinity and further articulate the relationship between nature and spiritual contemplation. This trend toward a greater respect for the individual's voice in the spiritual realm begins with the eighteenth-century spiritual autobiography. Even though the spiritual path remains demanding, Edwards and Ashbridge have more choice to act as individuals. For the male, Edwards inspires a closer association with nature and portrays a more contemplative, solitary figure. For the female, Ashbridge entertains new arenas altogether as she asserts her spiritual direction at the risk of displeasing male authority. The spiritual autobiography sanctions the first-person narrative as a legitimate vehicle for self-construction borne from self-examination. 


\section{ChAPTER 3}

\section{Declaring the Self in the Social Sphere: Dr. Alexander Hamilton and Elizabeth House Trist}

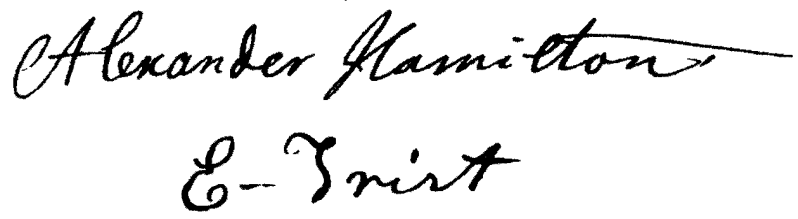

Unlike the captivity narrative's emblematic renderings of a spiritual journey or the spiritual autobiography's focus on conversion, the travel narrative tells of a physical journey whose ultimate meaning is determined by reaching a destination rather than by overcoming a spiritual test. Bridging earlier colonial American literature, in the form of the promotional tract and the diary, and later American fiction, in the form of the romance and the adventure, the travel narrative validates individual perspective and encourages individual investigation as the narrator moves closer to the center of the text and claims a new sense of authority. The travel narrative also responds to a growing population that has assumed ownership of its new lands and has made such an indelible mark on the landscape that the question is no longer, Why are we here? but, How can we improve and reshape what is here? Dr. Alexander Hamilton and Elizabeth House Trist journey along the roads and rivers of

Fig. 3. Dr. Alexander Hamilton's signature from his dedication to the Itinerarium, 1744, MS 922. (Reproduced by permission of The Huntington Library, San Marino, California.) Fig.4. Elizabeth House Trist's signature from a letter to Thomas Jefferson, from New Orleans, November 26, 1804. Trist is visiting her son, Hore Browse Trist, and his family. (Thomas Jefferson Papers; reproduced by permission from the Special Collections Department, Manuscript Division, University of Virginia Library.) 
eighteenth-century America and leave their own distinctive records of investigation. Hamilton's Itinerarium takes place in prerevolutionary America, 1744, and Trist's Travel Diary in postrevolutionary America, 1783-84, an interval that allows their narratives to frame a growing mobility of the individual in early America and the New Republic.

Although bonded by a common need to travel, their journeys were undertaken for quite different reasons: Hamilton's for health and Trist's for relocation. Hamilton was suffering from consumption (tuberculosis) and was trying to escape the hot Maryland summer. ${ }^{1}$ Trist was hoping to be reunited with her husband, Nicholas Trist, who had gone ahead to establish a settlement along the Mississippi River in the Louisiana Territory. Hamilton's more leisurely purpose focuses much of its 250 pages on social life in the expanding cites and towns of colonial America. Trist's sense of mission lends her narrative a more anxious tone. Hamilton embarks on a four-month journey through the northern colonies on May 30, 1744, from Annapolis, Maryland, continues north to Portsmouth, New Hampshire, and eventually returns to Annapolis on September 27, a venture covering 1,624 miles. It was, as Hamilton explains, "a very circumflex course, but as the journey was intended only for health and recreation, I was indifferent whether I took the nearest or the farthest route, having likewise a desire to see that part of the country" $(178){ }^{2}$ Elizabeth House Trist departs Philadelphia on December 21, 1783, with hopes of reaching Natchez by late spring or early summer. Trist's journal begins on December 23,1783, ${ }^{3}$ with a notation of her "6 O Clock P.M." arrival in Lancaster and breaks off at midsentence on July 1, 1784, just three days shy of Natchez. Hamilton returns home, recopies his journal, titling it the Itinerarium, and resumes his medical practice. The premature ending of Trist's Travel Diary is punctuated with the revelation that her husband had died in February while she wintered in Pittsburgh. Hamilton travels relatively easily through the established northern colonies, whereas Trist ventures into more unexplored territory. Hamilton and Trist each express desire for a more developed and, to their minds, a more "civilized" America: Trist imagines home and community, and Hamilton fancies genteel standards of social behavior and character.

Even though the Itinerarium's unique publication history deprived it of a contemporary audience ${ }^{4}$ and the Travel Diary was never intended for a public audience, each text anticipates one critic's criterion for the genre of eighteenth-century travel narrative by teaching "Americans the meaning of their unique historical situation. ${ }^{5}$ Through their extensive descriptions and social commentary of eighteenth-century life, they also satisfy the travel narrative's intention to instruct and entertain. Robert Micklus confirms that the travel narrative "naturally appealed to an age that stressed sociability as a key-if not the key-to happiness." ${ }^{16}$ In keeping with these intentions, the travel narrative encourages individual perception as its author projects his or her social vision out onto the landscape, village, or town. 


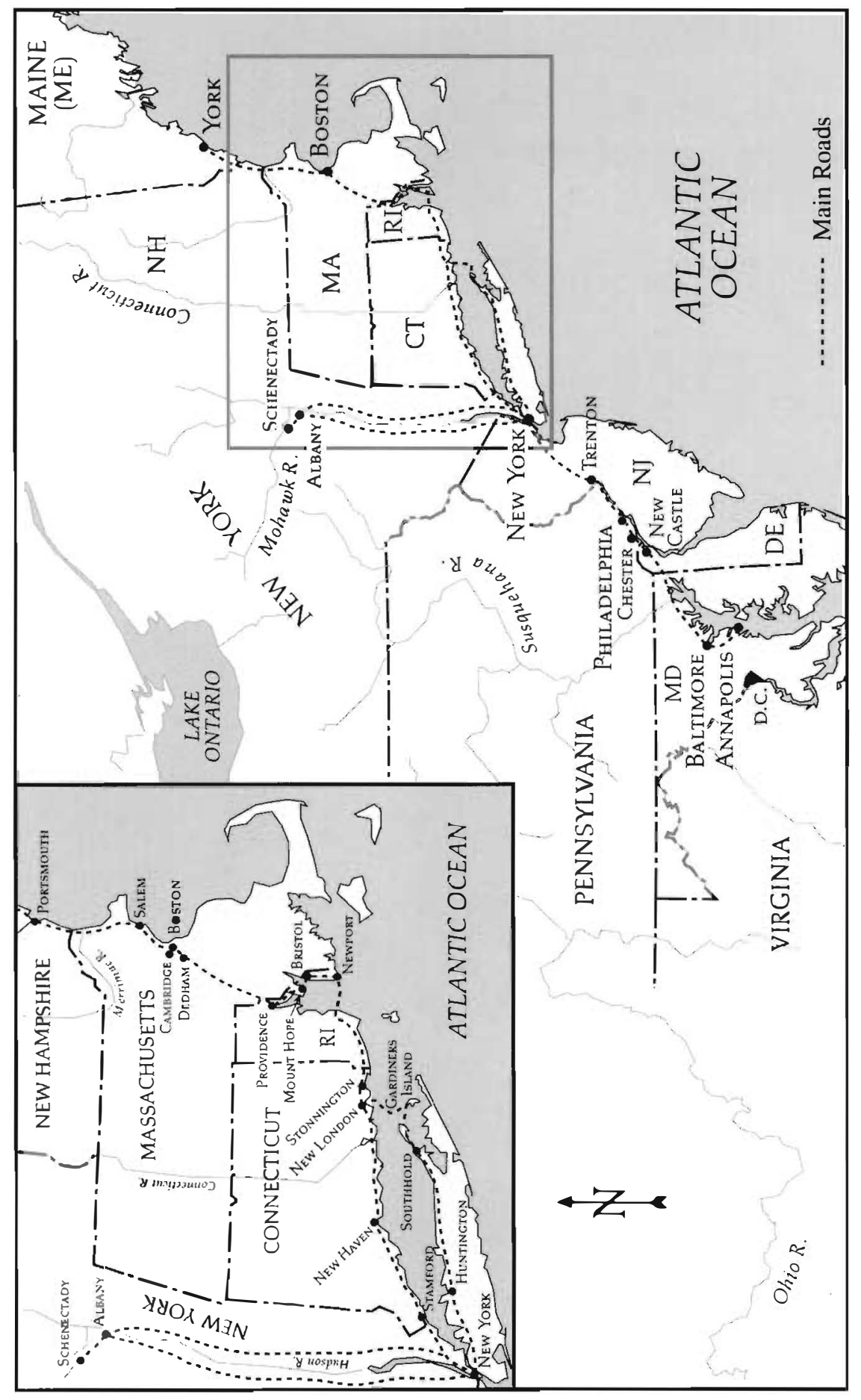




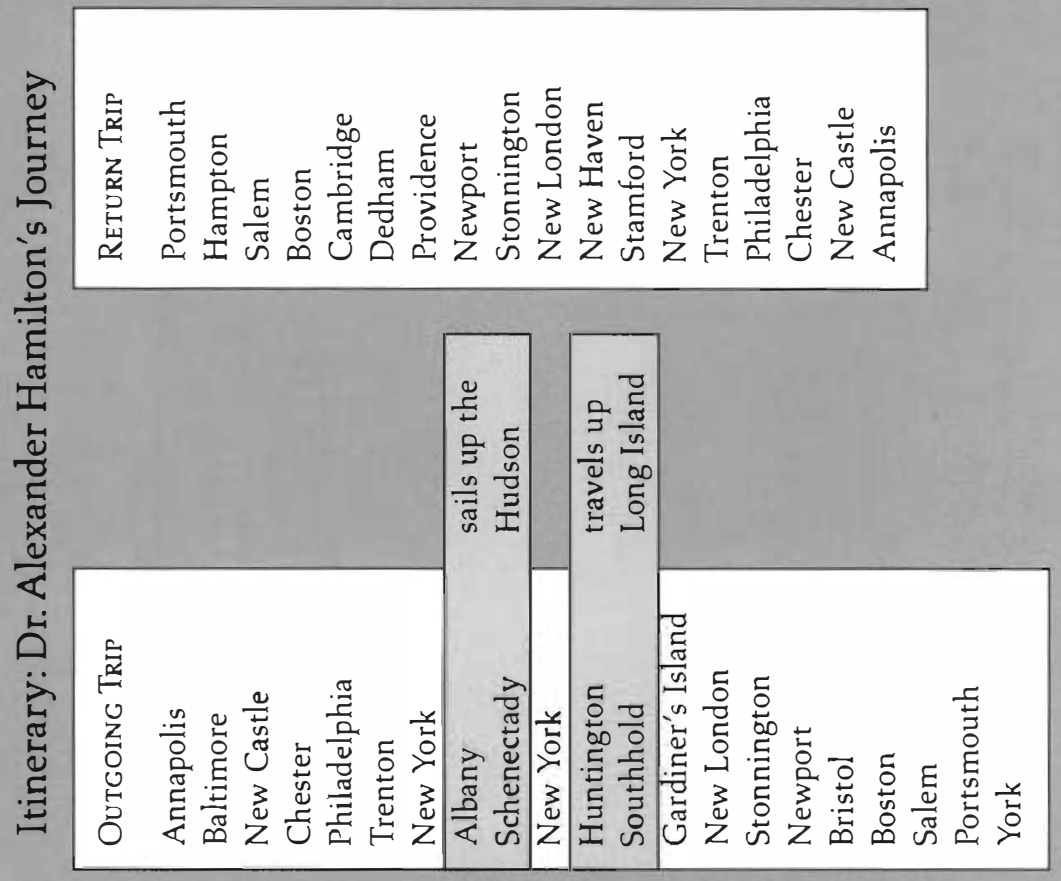

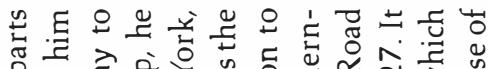
品

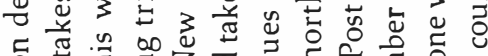

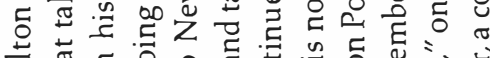

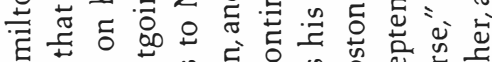
茫

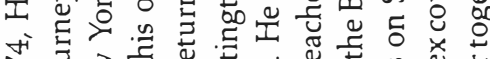

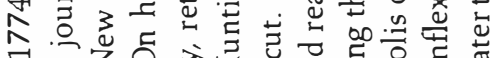

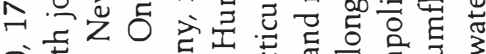
ণ 入

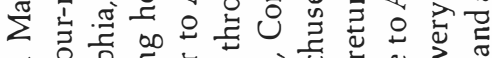

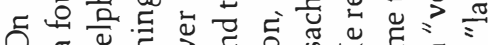

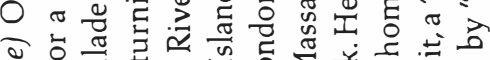

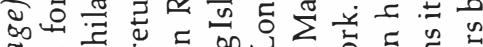

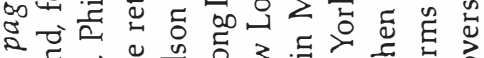

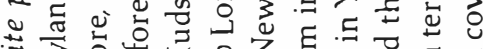

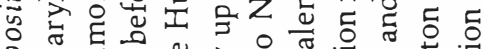

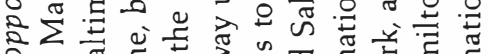

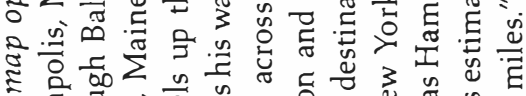

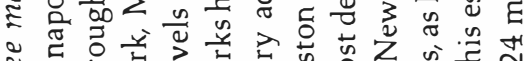

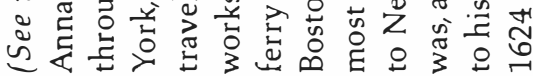


From this standpoint, the purpose of the first-person narrative shifts from a spiritual exercise in self-examination to a secular record of individual perspective. This subjectivity contributes to an autonomy that Myra Jehlen argues "provides a basis for community that comes from within, rather than as an external and limiting obligation" (15). The travel narrative also lends its author more authority by allowing the narrator to become the leading character, director, and producer of the journal's recorded events. This genre has, consequently, been considered "primarily responsible for advancing the authority and value of individual experience in literature." ${ }^{\prime 7}$ The Hamilton and Trist journals demonstrate this promotion of subjectivity.

Eighteenth-century travel literature distinguishes itself from the earlier promotional tract, whose Edenic imagery glorifies and exaggerates the plenitude of the New World, by grounding its observations in empirical details. Common to both writings is the author's projections of how the land will change and the settlements expand. For Elizabeth House Trist, the travel narrative allows her to evaluate the frontier for its potential to sustain community. For Dr. Alexander Hamilton, the narrative allows him to catalog colonial life and mark changes in social interactions and muse upon their implications.

As first-person narratives, Hamilton's Itinerarium and Trist's Travel Diary are invested with a strong sense of individual purpose. They each tell a story which is interesting because someone specific is telling it. Motivated by their intentions to explore and observe, these authors express an adventuresome spirit that anticipates both the romance and the Transcendental journey. With its own subjective emphasis, the eighteenth-century travel narrative distinguishes itself from the Puritan colonial diary and provides a foundation for the secular autobiography.

\section{The Traveler's View: Hamilton's Perspective}

Dr. Alexander Hamilton travels down rural roads and through colonial towns noting their character and speculating on potentials. Not driven by pressing concerns for reunion, Hamilton's leisurely journey allows for more reflection on the beauty and diversity of the colonial landscape. His entries often contain detailed descriptions of the local architecture, manners, and customs. As a physician, Hamilton sees his world through an empirical lens that gathers and records data and information and draws conclusions on such areas as health, diet, physical activities, intellectual pursuits, crops, and weather. His commentary is of ten witty and sarcastic, and his conversation is frequently comical and evasive. Fashioning himself as an independent agent, Hamilton maintains a public guise of nonchalance even though in private he is quite opinionated on subjects as diverse as taverns, inns, coffeehouses, food, women, clothes, healing arts, religious sectarianism, and commerce. These opinions enliven the Itinerarium with its unusual mixture of caricature and self-por- 
trait. In Hamilton's hands, the travel narrative also courts the style of the adventurous novel whose hero crosses the landscape with an outsider's perspective and encounters the unusual ways of its people.

Hamilton's actual quest may be far less dramatic than a Don Quixote's, but he still registers the expanding colonial scene with flair. He turns his eye upon all matters of social discourse, and as a traditional Scottish Presbyterian, Hamilton of ten uses the narrative as a forum for his observations of the enthusiasm lately generated by the Great Awakening. Although Hamilton is uniformly critical of this evangelical movement, he reserves his harshest criticisms for the religious "fanaticks." He is particularly incensed by the New Lights, followers of Rev. George Whitefield, the English evangelist and Methodist leader who was instrumental in inspiring the Great Awakening. In the entry for the Susquehanna Ferry, on June 1, for example, he writes about one of these enthusiasts, a "Scots-Irishman by name Thomas Quiet": "This fellow, I observed, had a particularly down hanging look which made me suspect he was one of our New Light biggots. I guessed right, for he introduced a discourse concerning Whitefield...." After this man delivers his message, Hamilton refutes his doctrines, which "put Mr. Quiet in a passion. He told me flatly that I was damnd without redemption." Hamilton has the last word by suggesting that the man change his name "with all speed, for it was very impropper that such an angry, turbulent mortall as he should be called by the name of Thomas Quiet" (182). Hamilton's dry tone here and pun on "quiet" suggest the influence of a Restoration comedy, for one might suspect the convenience of this man's name for Hamilton's particular illustration. Hamilton is quick to both identify Mr. Quiet as an enthusiast and criticize him for displays of passion. Hamilton prefers decorum. He is a reserved Presbyterian surrounded by the frenzy of a spiritual revolution-a curious mix.

Although intended to stand as discouraging critical judgment, Hamilton's harsh commentary of the Great Awakening inadvertently serves as a testament to religious diversity and the opportunity for individual choice in 1744 . Despite his disapproval, Hamilton is inundated with evidence of this spiritual movement. In the June 1 entry, for example, Hamilton writes about crossing Bohemia Ferry and notes that the landlord of the ferry house gave him "a short account of the spirit of enthusiasm that had lately possessed theinhabitants of the forrests there and informed [him] that it had been a common practice for companys of 20 or 30 hair-brained fanaticks to ride thro' the woods singing of psalms" (183). One can only speculate whether the landlord or Hamilton labeled these people "hairbrained fanaticks." Although Hamilton's remarks about each town's denominations take on a fascinated, sometimes irritated tone, his empirical tendencies do indeed provide an articulate record.

For all of its fanaticism, the spiritual climate is remarkably diverse. Colonial America appears as a land of religious choice and growing tolerance. On his first pass through Philadelphia on June 8, for example, Hamilton dines at 
a tavern with "a very mixed company of different nations and religions" and describes this tableau:

There were Scots, English, Dutch, Germans, and Irish; there were Roman Catholicks, Church men, Presbyterians, Quakers, Newlightmen, Methodists, Seventh day men, Moravians, Anabaptists, and one Jew. The whole company consisted of 25 planted round an oblong table in a great hall well stoked with flys. The company divided into comittees in conversation; the prevailing topick was politicks and conjectures of a French war. A knott of Quakers there talked only about selling flower [sic] and the low price it bore. The[y] touched a little upon religion, and high words arose among some of the sectaries, but their blood was not hot enough to quarrell, or, to speak in the canting phraze, their zeal wanted fervency. (191)

Hamilton presents an ethnically diverse group united more by politics and conversation than separated by religious or regional differences, and he seems to momentarily drop his elitist airs to en joy the spectacle of these twentyfive men "planted" around a large table. Hamilton notes these religious differences almost scientifically, as if cataloging and arranging a set of species. Even in his comments about the Quakers, whom he also considers part of the "fanaticks," he seems to flatter them by remarking that their business discussion takes on an almost reverential quality. Hamilton's commentary captures an animated colonial America engaged in the rigors of trading and the frenzied building of new towns, identifying an American spirit that will manifest twenty years hence in a fight for independence. This colonial pluralism not only counters the more hierarchical social structures of England and Europe, but it leaves a vivid impression of social change. Hamilton also finds this proliferation confusing, despite the industriousness. In Boston on August 16 , he remarks that there are "are above 25 churches .... [and] the people here have lately been, and indeed are now, in a great confusion and much infested with en thusiasm from the preaching of some fanaticks and New Light teachers, but now this humour begins to lessen" (284). This "infestation" remains troublesome, and Hamilton approves the waning of its "humour."

Even when Hamilton seems to accept this spiritually charged environment, he asserts his intellectual preferences for passion grounded in reason, as a proper student of the Scottish school. For example, on August 27 while on the Connecticut River, he records an especially distasteful display of enthusiasm:

After dinner there came in a rabble of clowns who fell to disputing upon points of divinity as learnedly as if they had been professed theologues. 'Tis strange to see how this humour prevails, even among the lower class of the people here. They will talk so pointedly about justification, sanctification, adoption, regeneration, repentance, free grace, reprobation, original sin, and a thousand other such pritty, chimerical knick knacks as if they had done nothing but studied 
divinity all their life time and perused all the lumber of the scholastic divines, and yet the fellows look as much, or rather more, like clowns than the very riffraff of our Maryland planters. To talk in this dialect in our parts would be like Greek, Hebrew, or Arabick. (297-98)

Hamilton is appalled that these "clowns" have taken on topics previously reserved for the formally educated. Spiritual authority comes from study, not from public conversion and loud debate. Hamilton is reluctant to entertain such access. This egalitarianism simply affronts his aristocratic roots. His assessments are often humorous but rarely kind, remarking on the "quacks," "barbers," and "greasy-thumbed physics" he encounters. Micklus, in fact, finds the Itinerarium a "running comic commentary on the major and minor irritants to a colonial gentleman" (Comic Genius 96). Through these gentlemanly preferences, Hamilton attempts to maintain the status of a gentrified class that holds itself above the laboring class, however secular or religious it may be.

Taking on the role of narrator, Hamilton would rather comment upon such scenes than participate in them, for when directly addressed, Hamilton can be rather evasive and contrary, suggesting both his individualism and his aloofness. In an entry on June 12 from Philadelphia, for example, Hamilton records his response to inquiries "about the state of religion in Maryland" by noting that " $[\mathrm{m}] \mathrm{y}$ common reply to such questions was that I studied their constitutions more than their consciences, so knew something of the first, but nothing of the latter" (197). The admission holds no regrets. Religion is simply not a central point of reference in Hamilton's affairs, and he often resents its importance. In New London on August 27, for instance, Hamilton responds to inquires about his home-town ministers in Annapolis: "I told him that the ministers minded hogsheads of tobacco more than points of doctrine, either orthodox or heterodox, and that the people were very prone to a certain religion called self interest" (296-97). Pointing out some apparent hypocrisy, Hamilton suggests that commerce is taking precedence over religion.

In some cases, religious behavior seems to have become somewhat superficial, and Hamilton struggles with betraying his gentlemanly ways by not complying with religious practices. On June 15, he visits Narrows Ferry and records a dining scene with his landlady and her two daughters, who begin by "put[ing] on solemn, devout faces, hanging down their heads and holding up their hands for half a minute," gestures which may seem surprisingly brief but remind Hamilton of his own poor manners, for he had "gracelessly fallen too, without remembering that duty according to a wicked custom [he] had contracted, sat staring att them, with [his] mouth choak-full." After noting this slip, Hamilton relates the following comical scene with an eye for his place within a new social custom:

They took such a deal of chawing that we were long att dinner, and the dish began to cool before we had eat enough. The landlady called for the bedpan. I could 
not guess what she intended to do with it unless it was to warm her bed to go to sleep after dinner, but I found that it was used by way of a chaffing dish to warm our dish of clams. I stared att the novelty for some time, and reaching over for a mug of beer that stood on the opposite side of the table, my bag sleeve catched hold of the handle of the bed pan and unfortunatly overset the clams, at which the landlady was a little ruffled and muttered a scrape of Dutch.... (205)

Excusing his "graceless" behavior by falling prey to some sort of "wicked custom," Hamilton is more embarrassed about his manners than overtly concerned with his failing religious duty. Hamilton as outsider is curious, but aloof as he records these "native" customs. His religious duty is again faltering, when on Sunday, June 10, while in Philadelphia, Hamilton includes this confession: "I intended to have gone to church, or meeting, to edify by the Word but was diverted from my good purpose by some polite company I fell into who were all utter strangers to churches and meetings" (194). To Hamilton, attending a church service might just as easily be forfeited for the pleasures of a coffeehouse or a stroll down main street. Given that the tavern is more attractive than the church for engaging in social discourse, his preference suggests the church is no longer the sole gathering point for colonial life and that a more predominantly secular society has emerged.

Whether commenting upon matters spiritual or secular, Hamilton's authoritative voice often reinforces his self-proclaimed position as arbitrator of taste and behavior. When he passes through Philadelphia in early June, for example, he describes a man who "began to rail bitterly against [the freemasons], as an impudent, assuming, and vain caball" (190). Hamilton judiciously adds, "Tho I am no free mason myself, I could not agree with this gentleman, for I abhorr all tyrrannicall and arbitrary notions" (190). Hamilton is not a man of extremes, and he rejects the irrational, instead gauging progress in terms of gentrification. After his homeward-bound visit to Newport on August 22, he notes: "I found the people in Newport very civil and courteous in their way. . . For rural scenes and pritty, frank girls, I found it the most agreeable place I had been in thro' all my peregrinations. I am sorry to say that the people in their dealings one with another, and even with strangers, in matters of truck or bargain have as bad a character for chicane and disingenuity as any of our American colonys" (292-93). The rumors that Newport residents are disingenuous are thus offset by Hamilton's direct observation of courteous people and pretty country girls. Still, they fall short in their dishonest business practices. The qualification "in their way" assumes that these people do not quite measure up to Hamilton's standards.

From his self-constructed image as gentleman rationalist, Hamilton positions himself as one who stands outside the cultural parade. Although this position may lend him some sense of authority, by his own hand Hamilton appears to be yet another character in this panoramic sweep of colonial Ameri- 
can life. He continues to cast himself into episodic adventures that fancy his wit and humor, and he gathers strength in his pose as the "objective" observer who would rather educate others than reveal himself. While dining in a tavern in Philadelphia, for instance, he recalls: "A gentleman that sat next me proposed a number of questions concerning Maryland, understanding I had come from thence. In my replys I was reserved, pretending to know little of the matter as being a person whose business did not lye in the way of history and politicks" (191). These comical self-depictions, in turn, reinforce the ties that the travel narrative has to American fiction. Hamilton himself becomes a type - the fashionably dressed gentleman traveling with his servant. $\mathrm{He}$ is both character and subject, and by frequently describing his own blustering, Hamilton becomes one of the many characters in his saga.

Through Hamilton's eyes, colonial life is thus articulated with a heightened sense of provocative characters whose antics provide him with an opportunity for criticism. Humorous and often irreverent, his sketches are studies in caricature. On July 14, in the section "Stonnington," he writes of "one Captain Noise, a dealer in cattle, whose name and character seemed pritty well to agree, for he talked very loud, and joaked and laughed heartily att nothing" (249). Perhaps Hamilton finds this man a captain of noise, for his boisterous, jovial manner seems unprovoked, a quality which might have appeared odd to the urbane Hamilton.

In another instance, on August 16, Hamilton visits Boston and notes the ramblings of "[o]ne Mr. Clackenbridge (very propperly so named upon account of the volubility of his tongue)," whose illogical manner Hamilton finds particularly annoying: "This was a little dapper fellow full of the opinion of his own learning. He pretended to argue against all the company, but like a confused logician, he could not hold an argument long but wandered from one topic to another, leading us all into confusion and loud talking" (283). The performance of this "dapper fellow" catches Hamilton's attention with his pretense to argue and his inability to sustain an argument. Hamilton continues with this scrutinizing and elaborates on his reactions after he has been listening to Clackenbridge. Here he critiques both the speaker and the listener:

My head being quite turned this night with this confused dispute and the thoughts of my journey to morrow, I got into a strange fit of absence, for having occasion to go out of the company two or three times to talk with Mr. Withered [owner of Cambridge club, Withered's], I heedlessly every time went into a room where there was a strange company as I returned and twice sat down in the midst of them, nor did I discover I was in the wrong box till I found them all staring att me. For the first slip I was obliged to form the best apology I could, but att the second hitt I was so confused and saw them so inclinable to laugh that I ran out at the door precipitatly without saying any thing and betook me to the right company. I went to my lodging att 12 o'clock. (283-84) 
Hamilton with tongue-in-cheek fears reprisal of laughter for his "strange fit," fully aware that his privileged position places him beyond the reproach of the "unpolished and rude" country people. Clackenbridge seems to have shortcircuited Hamilton, suggesting the infrequency of such encounters. Such odd behavior almost justifies Hamilton's criticisms, for associating with the illogical affects Hamilton quite oddly. From such portraits, we see Hamilton's genteel preferences, for Clackenbridge's wandering rhetoric and Captain Noise's unprovoked laughter are notable enough to find a place in his travel diary as curious specimens of human behavior.

Sometimes, Hamilton seems caught up in the human parade and expresses his genuine curiosity. On his homeward pass through New Castle on September 20, he encounters someone who appears to be "half man, half woman." He describes this person in some detail and then concludes: "I would have given something to have seen this creature turned topsy turvy, to have known whether or not it was an hermaphrodite, having of ten heard of such animals but never having seen any to my knowledge; but I thought it most prudent to pass by peaceably, asking no questions lest it should prove the devil in disguise" (323). Hamilton's civility seems to get the best of him as he deliberates whether to appease his curiosity, leaving yet another example of his articulate gaze. The doctor and the social scientist thus collide in Hamilton's observations.

Social commentary turns sarcastic once again on August 1 as Hamilton rides toward Portsmouth and meets a "very inquisitive" man. Hamilton explains that the stranger wanted to know: "where I was going, whence I came, and who I was. His questions were all stated in the rustick civil stile" (268). "I have noted down this dialogue," Hamilton concludes, "as a specimen of many of the same tenour I had in my journey when I met with these inquisitive rusticks" (269). This aristocratic slight allows Hamilton to mark his social distance and signals that this mixing of classes is fairly new and, to Hamilton, unwelcome. Richard Brown notes that "casual cross-class information sharing was not part of Sewall's Boston" (25), a period between 1676 and $1729 .{ }^{8}$ Hamilton's reluctance to embrace such "cross-class" interaction is punctuated by his preferences for the gentlemen's clubs and various coffeehouses that he frequents along his journey. ${ }^{9} \mathrm{He}$ would rather duplicate the life of the Scottish intelligentsia of his homeland than join in with the "rustick" population.

Hamilton's criticisms and caricatures find their most creative outlet when he recreates his moments in the various public houses of colonial America. In Philadelphia, Hamilton makes this visit on June 11: "In the evening I drank tea with Mrs. Cume and went to the coffee house. Att $7 a^{\prime}$ clock I went to the Governour's Club.... Severall toasts were drank, among which were some celebrated ones of the female sex" (195). We thus glimpse the drinking habits of these gathering spots, as virtually every tavern scene includes lively conversation punctuated by frequent toasts. During his extended stay in New 
York during July, in fact, he comments on the character of the people who "att the first appearance of a stranger are seemingly civil and courteous, but this civility and complaisance soon relaxes if he be not either highly recommended or a good toaper." ${ }^{\text {"10 }}$ Drinking is Hamilton's social elixir of choice: "To drink stoutly with the Hungarian Club, who are all bumper men, is the readiest way for a stranger to recommend himself, and a sett among them are very fond of making a stranger drunk" (241). Although alcohol provides a convenient bond, Hamilton also shows signs of weariness. After visiting the "two coffee-houses in this city," he admits, "I was tired of nothing here but their excessive drinking, for in this place you may have the best of company and conversation as well as att Philadelphia" (242). In Boston from July 18 to 27, Hamilton often stops by "Withered's, a tavern att the Change" where he catches up on news and gossip (256). On June 3, in Newtown, he enjoys refreshment with another traveler: "Att night I was treated by Captain Binning of Boston with a bowl of lemmon punch. He gave me letters for his relations att Boston. Whiele we put about the bowl, a deal of comicall discourse pass'd in which the landlord, a man of particular talent att telling comic storys, bore the chief part" (184). In many of these passages, Hamilton appears as the congenial aristocratic gentleman willing to mix with and, even enjoy, the various classes and ethnic groups that congregate at these inns. These are centers of social life where one can meet strangers, gather news, or exchange a joke. As David S. Shields sees it, these venues "enabled persons to bridge distinctions" based upon rank or profession (xx). Hamilton's tableaux demonstrate this potential and bring us into the tavern and the coffeehouse where he engages in the social commerce of early America.

Hamilton's self-portrait as social critic generally precludes a confessional tone. Upon his return visit to New York on September 4, however, Hamilton shares a meal with his friend, Todd, and notes: "We drank two remarkable toasts which I never before heard mentioned: the first was to our dear selves, and the tenour of the other was my own health. I told them that if such rediculous toasts should be heard of out of doors, we should procure the name of the Selfish Club" (309). Hamilton's monitoring of such personal notations signals a self-consciousness that briefly allows the mask of confidence to drop, and he realizes that his own subjectivity can render the meaning of each scene.

With its extensive details of social and industrial life, the Itinerarium also provides a dynamic report of an expanding commercial world. In many ways, Hamilton's narrative is a catalog of colonial treasures as he notes almost every settlement, town, and city that he passes through-expanding on the larger centers such as, Albany, Boston, New York, Philadelphia, and Salem. On Tuesday, June 5, for example, Hamilton passes through the town of Chester in the early evening and finds it "a pritty, neat, and large village, built chiefly of brick, pleasantly situated upon a small river... Over this river is a wooden bridge built with large rafters and plank in form of an arch. The State House is a pritty enough building" (188). Chester appears solidly constructed, 
sensibly planned, and properly integrated into its surroundings. Hamilton gives us an equally panoramic view of rural colonial America when, in an entry for "Blue Mountains" on June 24, he remarks upon seeing the Catskills how the "[l]arge open fields, and thickets of woods, alternatly mixed, entertains the eye with variety of landskips" (220). Whether town or country, Hamilton's physician's eye faithfully records the scene.

Hamilton also identifies commerce as a common denominator connecting these towns. Although tobacco remains a primary commercial crop for the colonies, Hamilton notes some diversification in Philadelphia, where the "staple of this province is bread, flower [sic], and pork. They make no tobacco but a little for their own use." He then tells of the "plain and levell" condition of the country and finds it "fruitfull in grain and fruits, pretty well watered, and abounding in woods backward." He predicts that this country is "upon the growing hand, more than any of the provinces of America" (19798). Similar agricultural observations are made on June 14 while on his way to "Princetown": ${ }^{11}$ there are "many large fields of wheat, barley, and hemp, which is a great staple and commodity now in this province...." He also marks a productive future based upon seeing "a great many pleasant fertile meadows and pastures" (200). In Albany on June 25, Hamilton notes "very good crops of wheat and pease" and remarks that these are "the first fields of pease" that he has seen since leaving England (221). On August 16, he describes the extensive shipping industry in Boston, where "[t]here were now above 100 ships in the habour besides a great number of small craft," and he adds that the "people of this province chiefly follow farming and merchandise. Their staples are shipping, lumber, and fish" (284). From such details, Hamilton charts the growth and industry of colonial America.

Hamilton of ten locates the unity of the colonies themselves within their own market interests rather than in their cohering allegiance to the crown that sponsors them. Private interest, however, can hinder rather than enhance their strength. For example, as the colonies become more interdependent and connected by ideas, they remain disconnected by separate currencies, a situation Hamilton finds burdensome, as he notes upon visiting Boston: "They have a variety of paper currencys in the provinces; viz., that of New Hampshire, the Massachusetts, Rhode Island, and Connecticut, all of different value, divided and sub-divided into old and new tenors so that it is a science to know the nature and value of their moneys, and what will cost a stranger some study and application" (285). Hamilton's complaints are well-founded, for the large amounts of cash that he would have had to carry for such a journey would have been quite burdensome and made him more vulnerable to robbers. To circumvent such misfortune and inconvenience, Hamilton presents letters of credit and introduction to prominent gentlemen along his journey whose verifications allow him to travel more freely and which provide both financial and social passports. Notably, the separating factor between the colonies appears to be cash while the connecting factor is credit which speaks to the 
need for a common currency that would both unify and simplify intercolonial travel and commerce. Hamilton's journal thus illustrates that as extensive travel routes make smaller towns more accessible and individual borders become blurred, colonial interaction is enhanced. For Hamilton, this mobility enhances his self-awareness. As he elicits reactions from "outsiders," Hamilton experiments with self-construction. If he can appear differently to his acquaintances in Annapolis than he does to the strangers he meets in Boston, then this contrast reflects some degree of his own subjective perspective. In 1744 town and village help define a person's character along with ethnicity, and as the country expands, this local identity will compete with a national consciousness of identity.

As Hamilton views his surroundings for both aesthetic properties and commercial potentials, he of ten compares colonial towns with styles of European architecture. While returning to the town of Chester on September 19, Hamilton makes these predictions, observations, and comparisons: "In its present situation it is much like one of our country market towns in England. When you are in it the majority of the buildings appear low and mean, the streets unpaved, and therefor [sic] full of rubbish and mire. It makes but an indifferent appearance att a distance, there being no turrets or steeples to set it of $[\mathrm{f}]$ to advantage, but I believe that in a few years hence it will be a great and a flourishing place and the chief city in North America" (321). The architecture is familiar and yet promises to transcend its current boundaries. We also learn of sanitary problems through his criticism, which suggests he has seen more efficient systems. On June 6, he notes the local architecture of Philadelphia, lending careful detail while asserting aristocratic tastes: "Att my entering the city, I observed the regularity of the streets, but att the same time the majority of the houses mean and low and much decayed, the streets in generall not paved, very dirty and obstructed with rubbish and lumber, but their frequent building excuses that. The State House, Assembly House, the great church in Second Street, and Whitefield's church are good buildings" (189-90). Hamilton's displeasure with Philadelphia is tempered here by his assessment of the "good buildings," and his observations tell of tremendous growth since the chartering of Pennsylvania itself in 1681, sixty-three years before his visit and suggests a city geared toward further expansion. ${ }^{12}$ From such comments, Hamilton anticipates the transformation of colonial America.

The travel narrative as historical document not only provides such valuable details but also demonstrates the inherent subjectivity of a social historian, especially one whose agenda reinforces class distinctions. For example, Hamilton draws comparisons between the people of Chester: "The people are much more polite, generally speaking, than I apprehended them to be from the common account of travellers.... Drinking here is not att all in vogue, and in the place there is pritty good company and conversation to be had. It is a degree politer than New York tho in its fabrick not so urban, but Boston excels both for politeness and urbanity tho only a town" (321-22). In 
Hamilton's preference here for the urbane, he evaluates Chester against a more sophisticated, or at least more complicated, style. Hamilton's association between the size of the town and its measure of politeness does seem a bit obvious, but implicit in Hamilton's preference for "politeness and urbanity" is not only an unquestioned assumption of future growth and expansion but also a privileging of continental design.

When the narrative turns to nature, Hamilton is not as interested as Trist will be in transforming the landscape or cultivating the garden. Instead, nature is key to empirical observation, and Hamilton records several scientific discussions, as in Newport on Thursday, August 23, where on an afternoon visit with a Dr. Moffat and Dr. Brett he has "a deal of learned discourse about microscopicall experiments, and the order, elegance, and uniformity of $\mathrm{Na}$ ture in the texture of all bodies, both animate and inanimate" (292). Here Hamilton offers the balanced, contained nature of the Enlightenment. Hamilton also devotes passages to natural beauty and geological composition, as when he travels through a village in Rhode Island called Tower Hill (or South Kingstown) accompanied by two Boston merchants, Benjamin Parker and Henry Laughton, on Sunday, July 15: "We viewed the sea from a high rock where we could see the spray beating with violence over the tops of the rocks upon the coast and below us, of three or four miles' extent, a pleasant green meadow, thro' the middle of which ran a pritty winding river. Most of the country round is open, hilly, and rocky, and upon the rocks there is a great deal of spar, or substance like white marble, but in very small pieces" (25051). Standing above the sea, Hamilton is protected from any immediate danger which allows him to appreciate the power of nature rather than imposing a desire to contain it. ${ }^{13}$ Hamilton declines to associate divine power with the natural forces before him; instead, nature is a power in its own right. Anticipating a Romantic depiction of nature, Hamilton inter jects a quality of "violence" in his description of the waves beating against the rocks which suggests their deliberate, almost malevolent willfulness.

At other times, nature appears bucolic and inviting. In late August, for example, he passes through Branford and finds it "a pleasant, delightfull part of the country, being a medley of fine green plains, and little rockey and woody hills, caped over as it were with bushes" (299). In yet another mood, nature is portrayed in a dreamlike fashion, providing a melancholy backdrop to his unhurried travels. After visiting Cook's Island, Hamilton records a somewhat Gothic scene: "This wild and solitary place, where nothing presents but huge precipices and inaccessible steeps where foot of man never was, infused in my mind a kind of melancholy and filled my imagination with odd thoughts, which att the same time had something pleasant in them" (216-17). Hamilton dwells in a sublime moment here by creating a relationship with nature that is both thrilling and potentially annihilating as he sails down the Hudson River inspired by nature's power. His delight upon seeing the "huge precipices and inaccessible steeps" towering above him as he is safely ensconced 
on a boat demonstrates nature's potential for either destruction or creation, oppression or transcendence. Hamilton confirms Thomas Weiskel's assessment that in the eighteenth-century sublime, empirical and emotional responses to nature can transport the self into transcendent states as "a sense of the numinous was diffused through all the grander aspects of nature" (14). Hamilton is inspired by nature as long as it does not cause physical discomfort or inconvenience. These passages expand Hamilton's index of colonial life and offer new models of interaction and a new sense of familiarity and comfort with the colonial landscape.

Given his literary interests, Hamilton may have been influenced by associations of nature with states of awe and decay, as he idealizes nature's imposing force. On July 4, for example, Hamilton describes Buttermilk Island located between Albany and York: "This appeared a very wild, romantick place surrounded with huge rocks, dreadfull precipices, and scraggy broken trees" (233). On July 14, in Rhode Island, Hamilton makes a more direct literary allusion; he records that after "travelling thro 12 miles more of stonny, rough road, we passed by an old fashioned wooden house att the end of a lane, darkened and shaded over with a thick grove of tall trees." To this already poetic image, Hamilton adds, "This appeared to me very romantick and brought into my mind some romantick descriptions of rural scenes in Spencer's Fairy Queen [sic]" (249). Here Hamilton equates nature with a rustic simplicity that charms and soothes him as nature's restorative effects are appreciated.

When Hamilton is not jotting down scenes of natural beauty or architectural wonders, his narrative is a study in pre-fiction. He embellishes his entries and represents himself and others in exaggerated circumstances. Influenced by his literary milieu, Hamilton occasionally mimics the Restoration comedy and the sentimental novel with his animated sketches of human character. Invested in language, Hamilton uses words as the medium through which he defines his physical world. The travel narrative obligingly provides this artist with a canvas upon which he constructs himself and his adventures. $\mathrm{He}$ is also a literary man whose readings along the journey include Cervantes, Fielding, Homer, Montaigne, Rollin, Shakespeare, and Spenser, a collection that suggests both a contemplative and adventurous mind. In fact, J. A. Leo Lemay considers literature Hamilton's "avocation" and credits him with "extensive" knowledge (222). Lemay also finds that the numerous colonial clubs contribute to Hamilton's literary interests. For instance, Hamilton visits the Hungarian Club in New York on June 16 and records, "[o]ur conversation ended this night with a piece of criticism upon a poem in the newspaper" (Itinerarium 209). And as Hamilton's previously noted commentary on "Mr. Thomas Quiet" might suggest, the literary world intrudes upon his rendering of the real world, which lends a semifictional tone to some of his more colorful portraits.

This fictional element is also apparent in Hamilton's characterizations of "rustick" characters. In a humorously authoritative tone, he writes from 
Philadelphia on June 6: "I observed Severall comicall, grotesque phizzes ${ }^{14}$ in the inn wher[e] I put up which would have afforded variety of hints for a painter of Hogarth's turn. They talked there upon all subjects-politicks, religion, and trade-some tollerably well, but most of them ignorantly.... I was shaved by a little, finicall, hump backd old barber who kept dancing round me and talking all the time of the operation and yet did his job lightly and to a hair. He abounded in compliments and was a very civil fellow in his way" (Itinerarium 190). The Hogarthian reference here places Hamilton's characterizations against the British style with its fascination for the odd and the peculiar. Amidst his witty repartee and apparently detached perspective, Hamilton displays his keen interest in humanity and delights in what amuses his fellow colonials. The numerous portraits of strong-minded individuals with passionate views about public issues further enliven his animated view of eighteenth-century American life. These satirical sketches, in turn, mirror those appearing in the contemporary British gazettes, the Tattler and Spectator, and suggest the talent that will later manifest upon Hamilton's return to Maryland, when he establishes the Tuesday Club. ${ }^{15}$ Hamilton embraces his individual mobility while also marking his preferences for class distinctions as he travels through colonial America. His portraits of cultural diversity imply a greater potential for class and cultural interaction than in either England or Europe, largely because of the less rigidly formed social structures in colonial America. In Hamilton's homage to Hogarth, he suggests a colonial scene which is evolving away from its British origins. Above all, his sketches display an author in control of his subjects, an artist in control of his pallet, a first-person narrative enthralled in its subjectivity.

Hamilton turns the brush upon himself, depicting himself as an object of curiosity in the passing pageantry of colonial diversity. On Wednesday, June 13, his arrival in Trenton, New Jersey, arouses curiosity, and his servant, Dromo, is questioned: "I was treated att my entry into the town with a dish of staring and gaping from the shop doors and windows, and I observed two or three people laying hold of Dromo's stirrups, enquiring, I suppose, who I was, and whence I came" (Itinerarium 199). In noting this natural curiosity, Hamilton reinforces how the extensive gossip networks operate throughout the colonies where information is gathered almost instantaneously upon the arrival of any visitor, a situation which supports Richard Brown's assertion that "[s]uch a phenomenon of information moving freely, without the exercise of personal discretion and out of context, was a new phenomenon with important ramifications for the redistribution of cultural and political power" (41). Hamilton tests this paradigm while traveling to Perth Amboy on June 15 where he meets two men: "First of all (as it is naturall) we enquired concerning news. I gave him an account of such scraps of news as I had picked up att Philadelphia," and "[a]fter discussing news" their conversation turned toward their horses and mutual professions (203-4). Hamilton's reference here to sharing "scraps of news" recalls Frank Shuffelton's note that in the 
New Republic "rich networks of epistolary exchange that passed on gossip, political news, and intellectual speculation" alleviated "a sense of personal isolation and social vacancy, of living distant from a society of like-minded men and women" ("Different Voices" 289). Hamilton's numerous entries noting lively conversations where gossip is freely exchanged support this evaluation.

Similarly, Hamilton's narrative reconfirms a study of Boston between 1676 and 1729 wherein Richard Brown finds that "face-to-face diffusion was the dominant mode" of mass communication in which "personal information networks seldom relied much on printing" (34). ${ }^{16}$ Moving from town to town gathering and passing on information, Hamilton himself becomes part of a network which is becoming increasingly democratic in both its sources and its consumers. Hamilton is then reflected and defined by the curiosity of the townspeople he encounters, leaving him to respond and, if he so pleases, alter his persona. These choices reinforce the narrative's capacity for subjectivity whereby Hamilton copies down his impressions, recreates scenes, and interprets the performances of both himself and his fellow colonials. To enhance these portraits, Hamilton of ten conceals his identity for fear of attracting even more attention. As if he is taking on the role of an omniscient narrator in a novel, Hamilton attempts to portray himself as an unseen observer. This stance would have been unforgivably narcissistic in a prior era. On June 16, for example, while strolling one afternoon along "severall of the principall streets" in New York, he describes how he was "guarding against staring about [himself] as much as possible for fear of being remarked for a stranger, gaping and staring being the true criterion or proof of rustick strangers in all places" (Itinerarium 208). Although Hamilton claims to spot the signs of "rustick strangers," he seems to be immune to similar accusations. He would rather gossip than be gossiped about. Hamilton thus affects an unassuming pose, one that Albert Bushnell Hart praises in his 1907 introduction to the Itinerarium: "[Hamilton] modestly refrains from discussion of his own family or condition and mentions his first name only in the dedication to his friend Razolini" (xi). Hart's admiration for Hamilton's restraint applies to travel literature genre in general, which derives its authority by providing facts and objective observations in order to fulfill its instructive intention. Including personal history would counter this intention.

Quite pleasantly, however, Hamilton often uses his "objectivity" to make highly subjective comments that lend his narrative a very specific perspective. For example, Hamilton meets "an old fellow named Smith" while stopping in Brookhaven and records this scene:

He showed us severall antick tricks such as jumping half a foot high upon his bum without touching the floor with any other part of his body. Then he turned and did the same upon his belly. Then he stood upright upon his head. He told us he was 75 years of age and swore damn his old shoes if any man in America 
could do the like. He asked me whence I came and whither I went. I answered him I came from Calliphurnia and was going to Lanthern Land. He swore damn his old shoes again if he had not been a sailor all his life long and yet never had heard of such places. (Itinerarium 244-45)

The passage not only demonstrates Hamilton's art for caricature but also signals his prevailing displeasure with the lowerclasses. J. A. Leo Lemay describes this behavior as a trend toward an "increasing democratization of manners in America," which "was an affront to an aristocratic gentleman" (Men of Letters 221). Still, Hamilton is slow to embrace this crossing of cultures and promotes, instead, a more elitist attitude toward the "rustics." As Micklus kindly puts it, "Hamilton was an Old World gentleman living in a crude and pushy New World, and he did not like the directions in which he was being pushed" (Comic Genius 110). The travel narrative allows Hamilton to elaborate on his frustrations. We are certainly given Hamilton's colonial America in this text, a subjective view with frequent examples of cross-cultural exchanges that provide a diverse portrait of colonial life. This subjectivity moves the travel narrative closer to fiction.

The Itinerarium again illustrates cultural diversity in another of Hamilton's exchanges with "inquisitive rusticks." This time he is on his way to Portsmouth, where on August 1 he records this dialogue:

"Pray sir, if I may be so bold, where are you going?" "Prithee, friend," says I, "where are you going?" "Why, I go along the road here a little way." "So do I, friend," replied I. "But may I presume, sir, whence do you come?" "And from whence do you come, friend?" says I. "Pardon me, from John Singleton's farm," replied he, "with a bag of oats." "And I come from Maryland," said I, "with a portmanteau and baggage." "Maryland!" said my companion, "where the devil is that there place? I have never heard of it. But pray, sir, may I be so free as to ask your name?" "And may I be so free as to ask yours, friend?" said I. "Mine is Jerry Jacobs, att your service," replied he. I told him that mine was Bombast Huynhym van Helmount, att his service. "A strange name indeed; belike your a Dutchman, sir, - a captain of a ship, belike." "No, friend," says I, "I am a High German alchymist." "Bless us! You don't say so; that's a trade I never heard of; what may you deal in, sir?" "I sell air," said I. "Air," said he, "damn it, a strange commodity. I'd thank you for some wholesom air to cure my fevers which have held me these two months." (268-69)

This encounter suggests that the notion of a leisured traveler, such as Hamilton, is somewhat uncommon in a society in which one travels primarily for trade. We also discover the significant information gap, or perhaps simply a lack of geographical knowledge, that would permit such a confusion over Maryland's location. And as names divulge ethnic origin, "Bombast Huynhym van Helmount" seems to suggest a Dutch lineage, and yet one 
wonders if Hamilton meant a Swiftian allusion to the horse-ruled country of the Houyhnhnms? Perhaps as a "High German" Hamilton can evoke an even greater level of eccentricity, a certain requirement for an "alchymist" who deals in air that apparently has medicinal powers.

Hamilton's imaginative self-fabrication reinforces the possibilities of selfinvention in a land where strangers are subjects of curiosity and, in this case, welcomed with great innocence. These "rustics" appear bothersome and boring to a man of his sensibilities, a reaction that reinforces his elitist attitudes and makes him "somewhat of a severe critic of his countrymen" (Hart xvii). Hamilton's privileged position allows him the luxury of travel for pleasure. Travel as entertainment offers him a chance to observe behaviors and render them comical or appropriate. The travel narrative legitimizes such observations by providing a venue for one to record such impressions, thus judging them important enough to be preserved.

Comparisons are of ten based upon Hamilton's appreciation for an educated class. For example, while in New York on September 10, Hamilton writes, in French and including a translation, to his Jamaican friend Monsieur de La Moinnerie. After acknowledging that he is "in perfect health" since leaving Boston," Hamilton notes, "I have known different climates and different faces since I last saw you. ... I have seen some men whom you might call fools, other men of ingenuity, but I have not yet met any learned men" (Itinerarium 315). Although Hamilton does not elaborate on what constitutes a "learned" man, one suspects it has as much to do with social standing as with formal education. Hamilton again passes judgment on his fellow colonials in a July 2 entry from Oversleigh, just after leaving Schenectady, in which he offers a lengthy critique of the Dutch: "But notwithstanding all this nicety and cleanliness in their houses, they are in their persons slovenly and dirty. They live here very frugally and plain, for the chief merit among them seems to be riches, which they spare no pains or trouble to acquire, but are a civil and hospitable people in their way but, att best, rustick and unpolished" (229-30). This backhanded compliment suggests that external appearance can be separated from moral character, and one wonders if Hamilton might just be a bit envious of the Dutch for their material prosperity. Perhaps the potential for upward mobility offends his gentrified ways. As part of a larger social masquerade, Hamilton codifies colonial culture as if to leave a map for the uninitiated. Certainly, Hamilton's own aristocratic manner makes him a vulnerable source of someone else's characterizations.

Even though Hamilton seems willing at times to accept the growing ethnic diversity of colonial America, his tolerance is eclipsed by his dislike for the Indians that he encounters along his way. After attending an English chapel in Boston, for example, Hamilton records this remark: "There sat some Indians in a pew near me who stank so that they almost made me turn up my dinner. They made a profound reverence to the parson when he finished; the men bowed, and the squas [sic] curtsied" (258). On his way to Albany on 
June 25, Hamilton describes how his party "went ashore to borrow another [canoe] to carry [their] baggage." Once there, he makes these observations: "We found the poor people there in great terror of the Indians; they being apprehensive that they would begin their old trade of scalping" (221). Hamilton can show sympathy toward the "poor people," but he still portrays the Indians as irrational and rash, suggesting that the colonials, not the $\mathrm{Na}$ tive Americans, are under siege.

Micklus notes Hamilton's particularly derogatory remarks toward Indians and finds that in Hamilton's mind, "the only noble savage was a cultivated one" (Comic Genius 99n.). Thus, when Hamilton does present a cooperative scene between the colonials and local tribes, it carries conditional praise, as on June 28, while exploring the town of Schenectady located on the "Mohook River": "It is a trading village, the people carrying on a traffick with the Indians - their chief commoditys wampum, knives, needles, and other such pedlary ware" (Itinerarium 224). He especially favors the Indians who have adopted "civilized" manners, such as the "Indian King named George," whom he visits on July 14 while traveling outside of Providence. Hamilton is impressed by the "twenty or thirty 1000 acres of very fine levell land round this house" and the "good stock of horses and other cattle." The closing passage reveals the true standard of his approval: "This King lives after the English mode. His subjects have lost their own government policy and laws and are servants or vassals to the English here. His queen goes in a high modish dress in her silks, hoops, stays, and dresses like an English woman. He educates his children to the belles lettres and is himself a very complaisant mannerly man. We pay'd him a visit, and he treated us with a glass of good wine" (249). By applauding King George for his apparent cultural assimilation, Hamilton is able to praise his behavior and express confidence that the "Indian problem" is diminishing. Considering that the travel narrative is Hamilton's own universe of ideas and references that gather symbolic meaning, his observations reveal distinctive patterns. The last passage then provides a contrast for a more impoverished portrait drawn from an encounter on Friday, August 31, on his way to York Island while breakfasting in Kingsbridge: "I saw about 10 Indians fishing for oysters in the gutt before the door. The wretches waded about stark naked and threw the oysters, as they picked them up with their hands, into baskets that hung upon their left shoulder. They are a lazy, indolent generation and would rather starve than work att any time, but being unacquainted with our luxury, nature in them has few demands, which are easily satisfied" (305). The poverty here is thus explained by the Indian's "nature," which stands in contrast to Hamilton's cultural preference for "luxury." He seems unable to imagine that they might not desire "silks, hoops, and stays." Although Hamilton sets himself apart from most everyone he meets, he more emphatically relegates the natives to the position of outsider. On July 17, he marks a waning of Native American strength when he visits Mount Hope and identifies it as "formerly the strong hold or ref- 
uge of an Indian king named Philip who held the place a long time against the first settlers and used to be very troublesome by making excursions" (253).${ }^{17}$ Hamilton suggests here that the "troublesome" threat of the native peoples has virtually disappeared even though in reality their numbers are still strong. Contrasting Hamilton's portraits of culturally diverse gatherings at colonial inns and coffeehouses, he clearly denies the Native Americans a place around the table.

Political discussions are another source for Hamilton's portraits. Talk abounded of the "dreaded" and "expected French war" $(181,187)$ or King George's War (1744-48), which was part of a larger series of territorial conflicts between France and England over land in Europe, Canada, and the western territories. General discussion of daily events was pervasive and not solely limited to elite circles. Hamilton notes in Philadelphia on September 15 that his "barber came to shave [him] and gave [him] a harangue of politicks and news" (319). During his first time through New York, Hamilton has tea at a "gentlewoman's house" where he meets "an old lady" whose "discourse ran upon news and politicks" (209). On his homeward journey, on September 20, Hamilton leaves this note from Newcastle regarding he and his friend, Gillpin: "[We] talked over politicks and news relating to Maryland while we were in bed before we went to sleep, and our discourse was interlaced with hideous yawnings, like two tired and weary travellers, till att last the nodding diety [sic] took hold of us in the middle of half uttered words and broken sentences" (323). Even the weary traveler shares information in Hamilton's colonial world, wherever he is - the market, tea room, barber shop, bedroom. Despite Hamilton's protestations of class mixing, gossiping was clearly pervasive and vital to the thriving network of information in colonial America. Hamilton's narrative marks a reorganization of information wherein boundaries are more fluid and possibilities more apparent. In recording these scenes with his spirited pen, Hamilton moves further away from the Puritan diary by expanding the scope of the first-person narrative to include the secular diversity and animation that surrounds him.

In addition to marking general patterns of social behavior, Hamilton also notes encounters between men and women that are particular to the growing colonial population. As Hamilton comments upon gender roles and expectations, he often holds the same prejudices toward women as he does for all others who do not meet his standards for class and decorum. He makes no secret of his ever observant, gazing eye that registers both his attraction for and, at times, disdain of "the fair sex." On one level, such entries reflect his status as a curious thirty-one-year-old bachelor. His unflattering remarks may also mask his insecurity about his health. In either case, Hamilton's travel narrative serves yet another function, this time as a personal diary. The association between health and bachelorhood is underscored in a letter written six months prior to the journey and dated November 6, 1743, when Hamilton refers to his health while explaining his unmarried state: "I shall only say I 
am not well in health, and for that reason chiefly continue still a Batchellor. I have more fatique [sic] and trouble than I care for, I find it a very hard matter to live well and grow rich" (qtd. in Lemay, Men of Letters 217). Despite the restrictions imposed upon him from his consumptive condition, Hamilton articulates his observations with keen discernment.

In the journal's first entry, for example, dated Wednesday, May 30, Hamilton notes a dinner guest whose "wife had no share in the conversation; he is blessed indeed with a silent woman." He then explains that this phenomena is due to a hearing defect which prevents her from understanding "what is spoke, and therefor not knowing how to make pertinent replys, she chuses to hold her tongue." With this odd definition of choice, Hamilton ends with a note to himself: "It is well I have thus accounted for it; else such a character in the sex would appear quite out of nature" (Itinerarium 178). Women are thus more appreciated for their silence than their intelligent contributions to conversation. Hamilton also appreciates attractive women, as on June 15, when he observes a woman waiting with her husband to board the York Ferry, describing her as "a beauty, having a fine complexion and good features, black eyes and hair, and an elegant shape. She had an amorous look, and her eyes, methought, spoke a language which is universally understood" (Itinerarium 206). This flattering portrait continues as Hamilton pays little regard for the content of her words: "While she sat there her tongue never lay still, and tho' her discourse was of no great importance, yet methought her voice had musick in it, and I was fool enough to be highly pleased to see her smiles att every little impertinence she uttered" (206). The woman shares a story about a sickly neighbor whom she fears will die because, "last night she had dreamt of nothing but white horses and washing of linnen." The symbolic imagery escapes Hamilton's interest, for as he confesses: "I heard this stuff with as much pleasure as if Demosthenes or Cicero had been exerting their best talents, but mean time was not so stupid but I knew that it was the fine face and eyes and not the discourse that charmed me" (206). Thus Hamilton catalogs women as he does the rest of his surroundings, with an eye for imposing his own standards and asserting his point of view. Not only does Hamilton enjoy occupying his role as narrator, but he seems quite comfortable in placing himself in the center as arbitrator of female behavior.

His observations of women of ten deem them as ornaments which decorate the colonial social scene, a view that may provide him with a convenient mask through which he can direct his comments while hiding behind the role of social commentator. Many of his observations include comparative statements, such as this comment on June 16, from New York: "The women of fashion here appear more in publick than in Philadelphia and dress much gayer." And he concedes that "the presence of a pritty lady, as I hinted before, makes even triffling agreeable" (208). In Newport, Rhode Island, on July 16 , he notes that the "town is as remarkable for pritty women as Albany is for ugly ones, many of whom one may see sitting in the shops in passing along 
the street" (252). In yet another instance, while on the return trip through Boston, Hamilton remarks that "this place abounds with pritty women who appear rather more abroad than they do att York and dress elegantly. They are, for the most part, free and affable as well as pritty. I saw not one prude while I was here" (285). He thus en joys the company of attractive women who are nicely dressed and who are neither too vocal nor too prudish. These passages also show that women apparently do have time to sit in shops and walk along the streets and that they are not all at home. Possibly, these are women in business or women of a more leisured class, the counterparts to the men that Hamilton sees in the clubs and inns.

The travel narrative allows Hamilton to shift roles from narrator to actor, providing him a chance to layer his subjective portrayal of colonial life. He not only presents a situation but also offers his reactions to it. In an entry for New York on June 17, for example, Hamilton declines a Mr. Jeffreys's suggestion that "to walk out after dusk upon this platform was a good way for a stranger to fit himself with a courtezan, for that place was the general rendezvous of the fair sex of that profession after sun set. He told me there was a good choice of pritty lasses among them, both Dutch and English. However, I was not so abandoned as to go among them but went and supped with the Club att Todd's" (210). Hamilton is reticent to engage in an illicit relationship, despite his sometimes derogatory comments about women. This passage leaves it unclear whether Hamilton was simply not in the mood that particular night, or if he ever visited "the fair sex of that profession" at all. In yet another way Hamilton records local "commerce," here with the "courtezan" as a potential commodity.

He may have refrained from soliciting a prostitute, but Hamilton is not above playing the role of the bon vivant. In Albany on June 26, Hamilton tells of having to politely kiss women while being introduced into "about 20 or 30 houses." He complies with this custom but then compares the scene to "a pennance, for the generality of the women here, both old and young, are remarkably ugly" (222). Hamilton as character shows that he can adapt to local custom, and Hamilton as narrator can impose his critical eye as to the benefits of his actions. These passages thus incorporate many of Hamilton's literary skills. He chronicles daily life, and he sketches the scene adding his criticisms and embellishments.

Although Hamilton's wit might sof ten the cruder nature of some remarks, he can be quite acerbic. In his discussion of the innkeeper, Madam Lay, on August 27, in Seabrook, Hamilton tries to ascertain the meaning of her name, and although he initially claims that "I find they are not quite so scrupulous about bestowing titles here as in Maryland," he finally decides: "I cannot tell for what, for she is the homeliest piece both as to mien, make, and dress that ever I saw, being a little round shouldered woman, pale faced and wrinkly, clothed in coarsest home spun cloth; but it is needless to dispute her right to the title since we know many upon whom it is bestowed who have as little 
right as she" (298). In light of his incredulity, Hamilton is telling us something about his sexual milieu and that apparently "Madam Lay" is a fairly common fixture in his colonial world. Moreover, Hamilton is not simply recording his social environment as Samuel Sewall might have recorded the weather, but he has elevated his subjectivity to the central point of the text through his judgments and speculations about others for his own amusement.

For all his dismissive remarks, Hamilton does occasionally enjoy a pleasant moment while in the company of "the ladies," as on August 22, in Whitehall, when he and his friend Dr. Keith "made an appointment for a promenade." He tells of a two-hour walk with three couples and notes that "[w]e enjoyed all the pleasures of gallantry without transgressing the rules of modesty or good manners." He even concedes: "I, with reluctance, bid the ladies farewell, expressing some regrett that, being a stranger in their town and obliged soon to leave it, I should perhaps never have the happy opportunity of their agreeable company again" (292). Hamilton softens his harsher criticisms with his genteel attitudes, for when there are suitable women, he is willing to play the gentleman. One wonders, however, if Hamilton's high standards are but a thin disguise for his insecurity about the "fair sex," as he seems to find them so generally unsatisfactory.

While Hamilton maintains the role of the eighteenth-century gentleman, he also seems fascinated by the role of the rake, as suggested by Dr. Keith. In Newport on July 16, Hamilton describes Keith as one who "passed for a man of great gallantry here, being frequently visited by the young ladies in town who are generally very airy and frolicksome." Dr. Keith then proceeds to display for Hamilton some "evidence" of his apparent gallantry: "He showed me a drawer full of the trophys of the fair, which he called his cabinet of curiositys. They consisted of tore fans, fragments of gloves, whims, snuff boxes, girdles, apron strings, laced shoes and shoe heels, pin cussions, hussifs, and a deal of other such trumpery" (253). Although Hamilton goes on in detail about the contents of this box, we are left to wonder what his interior responses are to this curious array of "trophys," for Hamilton simply concludes this passage by noting, "I lay this night att Dr. Moffet's [sic] lodging." The sense of anticlimax in Hamilton's account might further suggest that the reason for such a notation is largely voyeuristic - on either Hamilton's or Dr. Keith's part. In either case, these objects serve as metonymies for the supposed affairs that surrounded their acquisitions. The appearance supersedes the reality, and Hamilton's literary record embellishes the vision by leaving it to stand on its own, almost as if he wishes to revisit it and gather new impressions each time.

To read such passages against the context of the novel, sentimental novel, or the Restoration comedy is not so unlikely once we read of the literary world that Hamilton inhabits. When Hamilton attends a book auction a week later while in Boston, on July 24, he remarks that the "books that sold best at this auction while I was there, were Pamela, Antipamela, The Fortunate Maid, Ovid's Art of Love and The Marrows of Moderen Divinity" (Itinerarium 260). 
With the possible exception of the last title, Hamilton's contemporaries appear as interested in romance and the "fair sex" as the flirtatious Hamilton himself. But unlike the rakish character of the eighteenth-century novel, Hamilton expresses his ideas about women in the privacy of his journal while projecting an indifferent exterior. Hamilton does appreciate women who are lively, and his detailed portraits betray any indifference. While lodged in Boston near Beacon Hill on July 18, for example, he favorably describes his landlady, Mrs. Guneau, as "a French woman" who had "much of the humour of that nation, a deal of talk, and a deal of action," and yet he seems disappointed by the daughter, "a passable handsom girl, nothing of the French spirit in her but rather too grave and sedate" $(255,257)$. In praising the mother's spiritedness, Hamilton disregards the girl for her seriousness. When he returns to Boston in August, Hamilton again has tea with Mrs. Guneau, who tells him about a Church of England clergyman who, as Hamilton records, "lost his living for being too sweet upon his landlady's daughter, a great belly being the consequence." Hamilton then reflects, "I pitied him only for his imprudence and want of policy. As for the crime, considdered in a certain light it is but a peccadillo, and he might have escaped unobserved had he had the same cunning as some others of his brethern who doubtless are as deep in the dirt as he is in the mire... he was an excellent preacher; but the wisest men have been led into silly scrapes by the attractions of that vain sex ..." (272-73). The "certain light" of class distinction allows Hamilton to forgive this "peccadillo" and disregard the woman's circumstances altogether. Hamilton pities this man and does not appear shocked by this story, perhaps a common one. As these passages suggest, there appears no middle ground in Hamilton's polemical images of women. They are either unpleasant and vain or "airy and frolicsome."

Using his clinical, observational powers, Hamilton's assessments of a woman's nature include descriptions of her manner and dress. In Boston on August 9, he describes a daughter of a "countrywoman" as "a pritty buxom girl in a gay tawdry deshabille, having on a robe de chambre of cherry coloured silk laced with silver round the sleeves and skirts and neither hoop nor stays." Hamilton thus demonstrates his familiarity with women's clothing, and now having gathered the "evidence," he draws his conclusion: "By this girl's physiognomy, I judged she was one of that illustrious class of the sex commonly called coquettes" (276). Although Hamilton fails to record any conversation here, his judgments are based solely upon the girl's appearance. A woman is, therefore, not to appear too flirtatious nor too grave, if she is to capture Hamilton's eye.

Occasionally, Hamilton does meet an acceptable woman, although he rarely acts upon his attraction. At the conclusion of his letter of September 10 to Monsieur de La Moinnerie, Hamilton tells his friend that he need not "fear the winter in Boston, for the sex there is so full of charm and friendly warmth." Hamilton then concedes, "[B]ut I shall speak no more of it, leaving 


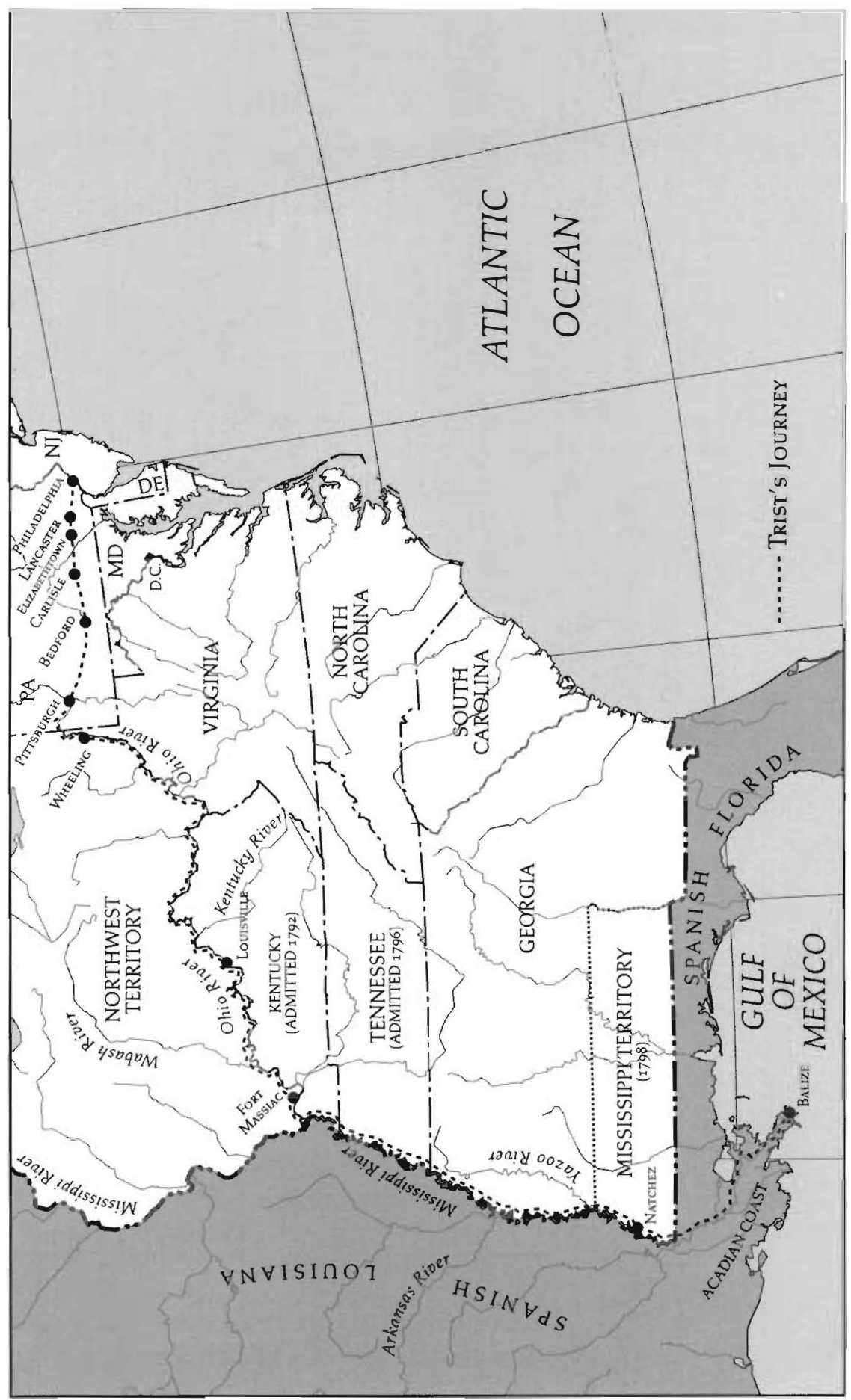




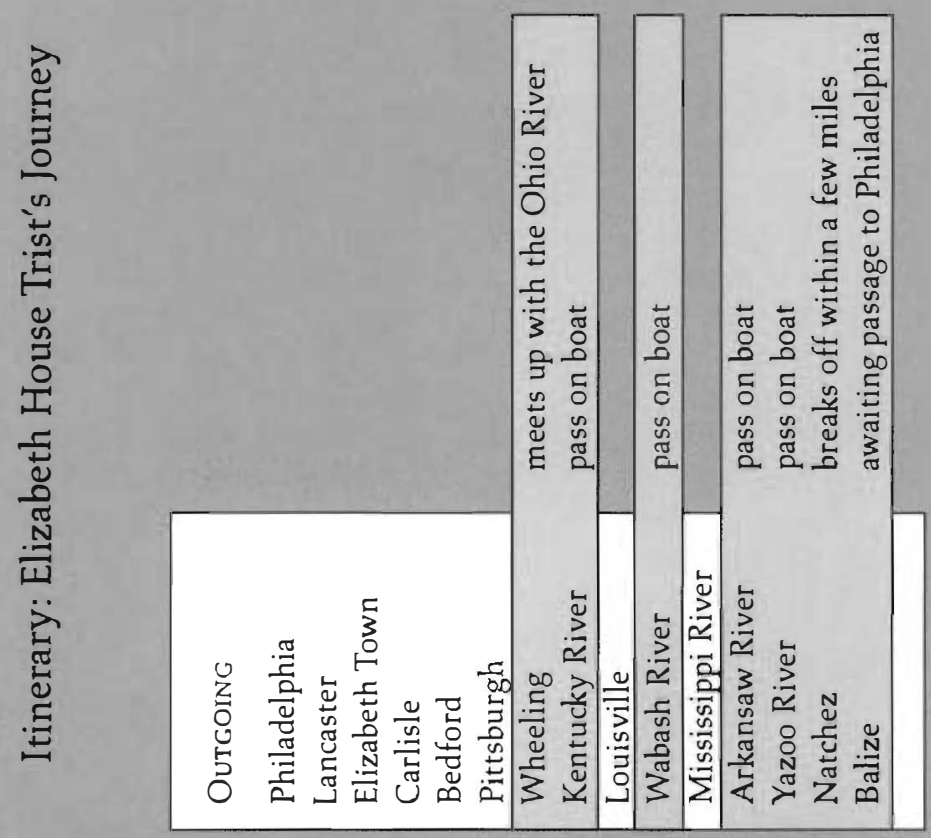

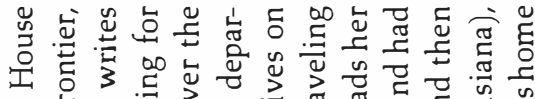

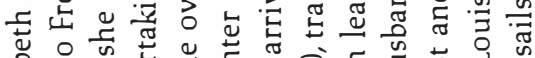

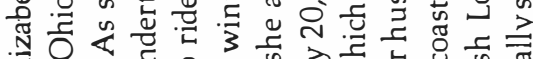
山ैं

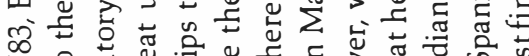

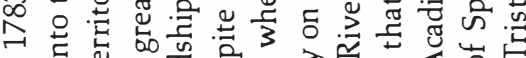
든 入

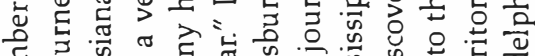

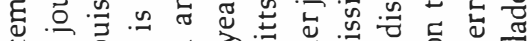

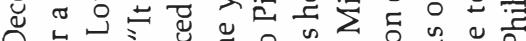
口

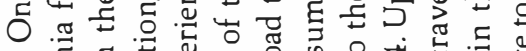

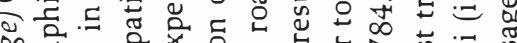
$\infty \frac{0}{\mathbb{N}}$ 웡

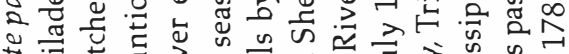

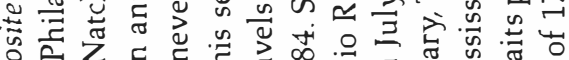

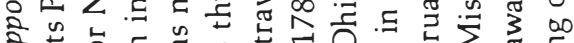

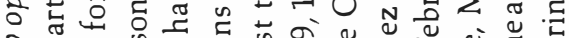
वे क्षे

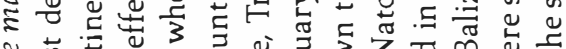
จ

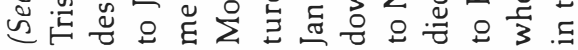


it to those who are their beholders and who are more warmer blood than I am, the cares of captivating them" (315). This admission of his lesser passion may either reflect his state of health or provide some explanation for his relentless criticism of women, for it is possible that Hamilton does not imagine himself capable of captivating such charming women. On Saturday, August 11, he records this response after breakfasting on chocolate at the house of Monsieur Bodineau, which was "well furnished with women of all sorts and sizes. There were old and young, tall and short, fat and lean, ugly and pritty dames to be seen here." Hamilton then singles out one "girl" who is described as having "small stature, no beauty, but there was life and sense in her conversation; her witt was mixed with judgement and sollidity; her thoughts were quick, lively, and well expressed. She was, in fine, a proper mixture of the French mercury and English phlegm" (279). Hamilton may express minimal interest in captivating these women, but he never ceases his observations. This flattering portrait offers a pleasant contrast to his usual condescension, for even though this woman is not particularly beautiful, Hamilton praises her intelligent, lively manner. On August 21, while traveling through Whitehall, Hamilton again seems genuinely pleased when he notes that the innkeeper's daughter was not only "a handsom girl" but "was the most unaffected and best behaved country girl ever I met with. Her modesty had nothing of the prude in it nor had her frolicksome freeness any dash of impudence" (290-91). Simplicity attracts him. Perhaps women have taken on a certain coquettish sophistication that proves either too complicated for this Scot or he is revealing his preference for the modest yet accessible country girl who appears to be out of place in the growing cities of colonial America.

Hamilton does seem to have found a few "properly balanced" women during his 1,624 mile journey. ${ }^{18}$ Among its other attributes, the Itinerarium offers a frank view of colonial America from the perspective of a willing bachelor who is bold in judgments and prudent in actions. A substantial part of the Itinerarium is composed of Hamilton's references to women, and the passages included in this section both articulate his viewpoint and suggest the literary influences of the eighteenth-century novel. For although Hamilton's actions hardly resemble those of Robert Lovelace, he does seem to admire the literary escapades of Tom Jones, and where Hamilton seems to value beauty over intelligence and independence, his preferences suggest a striking fit with Trist's persona, a woman with both wit and a pleasing manner.

Hamilton may think that he is simply taking notes, but in his hands, the travel narrative becomes a centerpiece for personal discourse with a distinctly authoritative point of view. With his objective physician's eye and author's speculative vision, Hamilton views these developments in the spirit of growth and expansion. For Hamilton, the spectacle of colonial life is mostly a secular pageant, one which provides him with rich material for his witty assessments. The nature of Hamilton's examination allows him to imagine society within his own preferences. In this way, the first-person narrative legitimizes indi- 
vidual perspective and judgment; it is the claim of authority stemming from his own critical intellect that stands out in Hamilton's text.

\section{The Traveler's View: Trist's Perspective}

Trist shares Hamilton's penetrating vision while advancing her own speculations on the future of the frontier. Inspired by thoughts of reunion and relocation, Trist expresses anxious hope as she ventures westward. Trist-theexplorer takes inventory of these new lands, and Trist-the-homesteader notes crop production, weather conditions, and entertainment. Through the complex texture of her voice, Trist provides a literary opening of the frontier which registers its potential and envisions a new life for herself, her husband, and their son. This willingness to imagine change is mirrored in her own life, which bridges colonial and postcolonial America. ${ }^{19}$

Prior to her journey, Trist's life was centered in a thriving Philadelphia scene. During the revolutionary period, Trist's mother, Mary House, ran a Philadelphia boardinghouse, located on the corner of Fifth and Market Streets, which had become the gathering place for prominent members of the Virginia delegation. It was here, in 1775, during the meeting of the Second Continental Congress, that Elizabeth worked for her mother and became acquainted with Thomas Jefferson, James Monroe, and James Madison, who were occasional boarders at the establishment between 1775 and $1791 .{ }^{20}$ It was also during this time that Elizabeth House met Nicholas Trist, when he was a British officer stationed in Philadelphia during the war. ${ }^{21}$ They married in 1774, and shortly after the birth of their child, Hore Browse Trist, in 1775, Nicholas Trist set off to find a settlement near Natchez where the new family could establish a home. War had made it too dangerous for Elizabeth Trist and her son to join her husband immediately, so they stayed behind. With the signing of peace treaties in 1783, it appeared safe enough for Elizabeth Trist to travel, and so in late December 1783, she departs Philadelphia, without her son and accompanied by a small party, to begin an arduous westward journey to the frontier settlement of Natchez. ${ }^{22}$

Given Trist's motivation to reach this destination, her narrative is concerned with the material and the pragmatic. She writes with an eye for removing impediments in her journey's progress and for creating a more comfortable social and physical environment. On December 25, 1783, she records: "The weather's moderated a little but very ruff roades" (Travel Diary 201). On December 31, however, the snow is so deep that she rides with "Snow up to the Horses bellies" (204). Her vision broadens on January 9, 1784, as she looks out upon the landscape while standing on Grants Hill overlooking the town of Pittsburgh and remarks: "if the country which is mountanous was cleard, it wou'd be beyond description beautifull. ... and, was there good Society, I shou'd be contented to end my days in the Western country" (213). Following Crevecoeur, Trist agrees that civilizing forces will enhance the fron- 
tier, and so she measures its value according to its ability to provide "good Society" and to cultivate good crops: "The land is exceedingly rich and abounds with an abundance of maple trees, from which they make quantitys of sugar. ... There are several wild vegetables that I wou'd give the preference to those that are cultivated: Wild Asparagus, Indian Hemp, shepherd sprouts, lambs quarters, \&cc-besides great abundance of Ginsang, Gentian and many other aromatick." She also takes inventory of mineral sources, as here when she describes Cole Hill: "At one side it has been open'd to supply the inhabitants with fuel. It is equeal [sic] in quallity to the $\mathrm{N}^{\prime}$ castle or any other I ever saw" (212). Trist appears optimistic. The land not only bears food but also promises to yield necessary commodities for sustaining a community.

Like Hamilton before her, Trist is quick to impose her own standards. Trist's allegiances to her home run deep, even when discussing fruit: "About 10 came to a very pretty glade full of fine ripe plumbs. There are great quantitys of them growing in this country, but I dont think they are as large as those that grow in Pennsylvania" (228). Such comparisons lend subjectivity to her travel narrative, which supports judgmental tendencies by encouraging comparative assessments. Trist has left the comparatively cosmopolitan atmosphere of Philadelphia for this cumbersome trip down the Ohio and Mississippi Rivers, and she continues to hold city life as the standard by which she measures the frontier world. Finding it wanting, she is anxious for change, yet she is not flamboyant in her descriptions. The realistic, straightforward record of her journey, in fact, contrasts an explorer's bravado that might exaggerate or idealize his or her findings. When she does speculate about the future, her projections are critically formed and based upon quantified observation as she envisions the possibility of increasing town and community in the frontier of the New Republic.

Following Trist's desire to transform the surrounding landscape into a home, she writes with the confidence of a developer who views trees and mountains as mutable objects destined for removal and renovation. The spirit of the place is subsequently measured by its social potential, and Trist's reactions depend upon the prevailing circumstances. When travel is steady and conditions are pleasant, her entries offer favorable reports. When either factor is troublesome, Trist's record takes on a more anxious and, sometimes, condescending tone. In either condition, the frontier is not glamorized.

These characteristics are especially true regarding her notes on housekeeping and entertainment. Trist remarks on January 3: "Our entertainment was as good as if in a city" (Travel Diary 207) ${ }^{23}$ Her comments range from being "Hospitably entertaind" at Captain Simpson's House on December 26, 1783 (203), to passing a "bitter night" in a "miserable dirty place" on January 8, 1784, while staying on Mr. Eliott's farm (210). Preferring cleanliness and privacy, Trist seems to resist the realities of pioneer life and being subjected to necessity. At times she is condescending, such as on January 1 , 
while spending a night in a private house that only "consisted of two rooms," where "the private room was occupied by the Colonel, his lady and children." Trist and her traveling companion, Polly, are made to spend the night in a common room, "which serv'd as kitchen, cellar, and Hall, [and] had two dirty beds." Unaccustomed to such conditions, Trist sleeps fully clothed in order, as she explains, "to keep my self from the dirt off the bed cloaths. Neither cou'd I sleep for the crying of the children and the novelty of my situation" (205). Everyday concerns are central to Trist's response to the frontier.

People and nature are subject to Trist's criticism. Entries concerning river travel often reflect a traveler at odds with her physical environment: "[May 28] my mind was not at ease: the water of the river was every day decreasing, and I was under great anxiety least we should be detained till the Autumn" (220) ... [June 5]: "The river is low which will lengthen our voyage very much. We go but 30 mile in a day ..." (220). Her dissatisfaction with accommodations is thus matched by her discomfort with the physical environment. Her sense that these factors rather than her attitude are capable of alteration tells us that, for Trist, the first-person is more than just a point of view; it is a statement of being.

Certainly, she is neither Jonathan Edwards, whose soul trembles and thrills at the sound of God's thunder, nor Samuel Sewall, who wonders if the rainbow is not indeed a sign of God's pleasure. For the most part, nature appears as a purely physical phenomenon, and gone are Sewall's images of natural marvels and Edwards's references to supernatural powers associated with thunder and lightning. On January 6, 1784, she records weather conditions with more concern for travel than divinity: "Was waked in the Morning by a pretty severe Thunder Storm and a very great fall of rain, which had melted all the Snow and obliged us to proceed on our journey-tho the rain still continued-for fear the creeks riseing shou'd detain us for several days ..." (207). When she writes about a June thunderstorm, Trist does note its power: "The trees crack'd about us, and it thunder'd, lightned and rain'd as if heaven and earth were coming together" (224); "This a Passionate sort of climate, quickly raised but soon blows over" (228). The storm excites her, yet she never praises nature as a spiritual or romantic force. On May 20, 1784, for example, she notes: "Three days rain has swell'd the rivers, and we have the flattering appearance of a speedy voyage" (214). On June 18, she finds her "patience is allmost exausted. What with the Musquitos and head winds," which lead her to admit that she is "allmost sick" (227). Trist perhaps deserves our sympathy when she notes on June 6,1784, "After a disagreeable night tormented with Gnats and Musquitos, we left our moorings at the dawn of day" (221). Instead of portraying nature in a mystical fashion, therefore, Trist's relationship with her environment is primarily a pragmatic one.

In Trist's record of the changing natural environment, she also illustrates the impact of travel and expansion. Such entries mark the rapidity with which settlements are appearing and wildlife is disappearing. In the twenty years 
since the French and Indian War (1754-63), she observes that "[ $t$ ]his country, the last war, was the frontier" (203). On May 26, she files this report of environmental impact when her party cannot find game after an hour's search, suggesting an intrusive influx of traders and travelers: "[O]ur hunters return'd without any game, which was a disappointment as we expected to have had some fresh meat for dinner. There are such numbers of boats continually going down the river that all the game have left the shore" (217). Gone are the images of the earlier promotional tracts of the seventeenth century with exaggerated visions of limitless game. Instead, Trist's record suggests a veritable expressway of travel where humans are becoming the more plentiful species. Trist's immediate concern here is with food, yet she also discloses an inevitable result of human impact.

On June 15, Trist again notes the lack of game on what was supposed to be "the best hunting ground any where on the river." This section concludes with this report: "As our provisions are allmost ex'austed, tis agreed to lay by for this day in hopes of killg some deer. The men returnd without even having fired a gun" (226). Confirming her earlier observation, the company remains without fresh meat. Discouraged but not defeated, the crew is apparently unclear about what they are hunting for, as Trist notes on June 7, "our people went on shore to hunt and kill'd a tame cow which they mistook for a Buffaloe. However, it turned out very good Beef" (221). Assuming that this is indeed buffalo country, this "mistake" further suggests that either the wildlife have sought refuge out of harm's way or that the Buffalo are endangered even at this early date. Other possibilities here are that either these hunters are a bit dim-witted in their initial mistaken identity of a cow for a buffalo or that Trist is covering up for their poaching. From such incidents, Trist and her crew project a commodified view upon the landscape and the wildlife as potential products. The river is not a site for glorified adventure, but rather the means to her domestic ends. For this 1784 traveler, there is still more land that is wild than developed, and she sees tremendous opportunity for this undeveloped landscape.

Trist's narrative emphasizes human imperative over appreciation for nature or environmental preservation, and the journal's observation mode sanctions such opinionated discussion. When travel appears obstructed, therefore, Trist is displeased with nature, as in early January: "For my part, I felt oppress'd with so much wood towering above me in every direction and such a continuance of it. A little opening now and then, but a very confined Prospect: nothing but the Heavens above and the earth beneath, and a pretty spring bubbling every here and there out of the side of a Hill" (213-14). This oppression is peculiar. Is she feeling overwhelmed by her journey? The openings provide her some relief, but the prevailing mood is troubling. Trist is not interested in experiencing the sublime in nature, as Hamilton does when he describes the beautiful terror of the ocean. Instead, Trist feels "oppress'd," which suggests that she may not have been sufficiently distanced from the 
terror of this potentially sublime landscape. Edmund Burke's 1757 Philosophical Inquiry into the Origin of Our Ideas of the Sublime and the Beautiful, which falls in between the Hamilton and Trist narratives, identifies sublime sources as producing the "strongest emotion which the mind is capable of feeling" (58). Burke also explains that without careful modulation of these sources, "they are incapable of giving any delight, and are simply terrible; but at certain distances, and with certain modifications, they may be, and they are delightful, as we every day experience" (59-60). Trist's reactions confirm these stipulations just as they signal the shifting attitudes toward nature. For Trist, the individual determines the value of the landscape. Nature is praised for how it can support human life rather than as a spiritual force.

Instead, Trist sees unyielding nature as an impediment to her journey's objective. Consequently, the entire river is subject to her revisions: "I have various Ideas about this river:- [I] some times conceit-I am got to the fag end of the world; or rather that it is the last of Gods creation and the Seventh day came before it was quite finnish'd. At other times, I fancy there has been some great revolution in nature, and this great body of water has forced a passage were [sic] it was not intended and tore up all before it" (Travel Diary 227). Violent images of revolution and destruction imply that she has entered unsanctioned territory. Trist depicts nature as disturbing with mosquitoes biting, rivers raging, and desolate landscape all around. Rather than conceiving her surroundings as the handiwork of God's creation, Trist dismisses them as unfinished. Yet her admission that "there has been some great revolution in nature" suggests some admiration for the sheer physical power of nature.

These mixed responses may also reveal a deeper ambivalence about being out on this grand river. She has not seen her husband for many years and has traveled under harsh conditions leaving her friends and family behind, circumstances which might certainly have contributed to her alternating fear and awe. Trist's mood might suggest what Annette Kolodny marks as the "essence of the pastoral paradox: man might, indeed, win mastery over the landscape, but only at the cost of emotional and psychological separation from it" (Lay 28). In one particular episode, Trist illustrates this complicated response to nature, wanting at once to admire it and also to contain and destroy it. A "fine Majestick looking bird" has been flying around her boat until: "One of our people kill'd one and brought it on board the boat." Trist records its measurements as "ten feet from the tip end of one wing to the other" and notes that "the bill resembles white leather and expands in an extraordinary manner." Her commentary then betrays her curious excitement: "I saw 14 quarts of water put into its mouth, and it wou'd have held more. I can not comprehand what use they make of this amaizing pouch, unless to scoop up the little fish. They are very harmless and so tame that they swim allmost in reach of our oars" (Travel Diary 229). Her admiration is oddly mixed here with the admission that one of these "majestick" birds was killed simply for the opportunity for closer observation, as there is no mention of eating it. The 
subsequent measuring and manipulation of the bird further removes it as an integral part of nature and marks it instead as a curiosity. These calculations of wing span and bill capacity suggest a disturbing alienation from nature. Kolodny finds Trist's "fascination" here indicative of the "waste and despoliation that marked even the earliest years of frontier settlement" ("Introduction" 193). Trist's attitude serves as an unfortunate premonition of greater environmental neglect to come. For, as Trist and her crew lack reverence for the land and the wildlife, they appreciate them for what they are capable of yielding for future homesteaders.

Trist's insecurity toward the journey itself may be the cause. When the trip progresses as planned, her initial fears give way to a greater confidence with frontier travel. Consider the contrast between her early and later entries. The diary begins with Trist struggling with winter travel:

Upon the Summit of the Mountain, my saddle turn'd. It was with great difficulty I cou'd stick upon the Horse. ... We suffered another inconvenience for want of a breast plate to our saddles, for some places that we had to ascend where [sic] allmost perpendicular, and our saddles slip'd so that we cou'd scarcely keep our selves on by holding the main ... (205). Indeed, this days journey has been as dangerous as any we have gone through. The small runs as well as creeks were all most impassible. The Horses were frequently near swimming ... the roads very bad. My Horse cou'd scarcely keep his feet. He fell with me once, but I was so lucky as to keep my saddle. (208)

Even though she finds herself holding on for life in the wilds of this new landscape, Trist rises to the challenge. It is only later, after spending several months in Pittsburgh waiting for the weather to improve and the rivers to melt, that she grows depressed and her passages become gloomier. But with spring and the promise of renewed travel, Trist displays an increasing enthusiasm for adventure. Not only are her comparisons with the city less frequent, but she regrets having to endure the limitations imposed upon her as a female. Trist maintains her primary concern with reaching her destination safely, but as travel becomes easier, her appreciation broadens. In a springtime entry, Trist even celebrates the beauties of nature: "I am allmost in extacy at the Magnificence of the display of nature. The trees are deck'd all in their gay attire, and the earth in its richest verdure. So much for blooming May" (215-16).

This enthusiasm encourages one to speculate that if the journey itself had ended differently, she may have more fully enjoyed the beauty surrounding her. With the diary unfinished and the hoped for reunion with her husband unrealized, Trist offers only a hint of her capacity to embrace the wilderness. ${ }^{24}$ She was at least willing to experience the dangers of traveling through this largely uncharted territory. Several times Trist expresses a greater desire to explore her surroundings, but she is largely discouraged. For example, she complains about not being able to see fossil remains: "The difficulty attend- 
ing my getting there, for want of a guide and other obstacles, obliges me to give up all thoughts of satisf ying my curiossity" (217). Being protected from danger of ten leaves Trist with a feeling of missing out, as on June 13: "Mr. Bevird and two of the men went on shore in hopes to get a hunter. I was eager to accompany them. I wish'd to see the fort because it bore the name of my friend, but I was dissuaided from making the attempt as it was not certain what Indians might be there" (225). Trist is excited by the possibility of seeing Fort Jefferson, but she has little cultural support for adventuring out on her own. Nonetheless, her Travel Diary marks a transition in the perception of the female traveler in American letters, as she is both courageous and confident. Trist's journal, in turn, charts the shifting of the self as observer in a landscape that finds the self, and neither divinity nor nature, at the center.

Just as she cannot entertain ideas of solitary communion with nature, cultural premises prevent Trist from appreciating her encounters with the Native Americans. Her general attitude is that the Native Americans, not her party, are the intruders, and she is more anxious and curious than sincerely interested. On May 23, she explains: "We pass'd an Indian camp in the night. We cou'd hear them yell, but it was too dark for us to see them" (216). Native Americans are nonetheless a formidable presence. When she meets former members of the Delaware tribe and their chief, James Dickison, she describes him as a "sensible fierce looking fellow, but his character is very bad. They say he has plundered several boats and murdered many people that have been going down this river" (222). Trist seems caught in the dramatic lore of this man which heightens the novelistic tone of her narrative. Despite her preconceptions, she writes, "My curiossity led me to visit them, as they had all the appearance of friendship.... As it is good to have friends at court, I carried the Squaw some bread; and as her Infant was exposed to the sun, I gave her my Hankerchief to shade it, for which she seem'd very thankfull" (222). Her reference here to "friends at court" might imply some recognition that Trist herself is indeed the intruder here, an implication, however, that Trist neither acknowledges nor reinforces throughout the text. Another possibility is that Trist is being deliberately ironic; in which case, she echoes Hamilton's derogatory attitude.

Trist's discomfort recalls a connection that Leland Person makes in his discussion of miscegenation in frontier fiction. He notes that because women were generally excluded from "men's nature-culture," female novelists, such as Lydia Child and Catherine Maria Sedgwick, present alternatives to the male frontier fantasy (684). One response is the frightened heroine, another the strong-willed homesteader. Trist falls somewhere in between these types as she struggles with social expectations of a female's response to the wilderness. Although she is appalled by the crude living conditions, Trist's semireverent approach to Chief Dickison might suggest some potential for admiration, however repressed. From her orientation, she only sees poverty where simplicity exists. Lacking understanding or compassion, Trist believes the trans- 
planted Americans to be the rightful inhabitants. Trist illustrates an attitude that Cecelia Tichi identifies as "geography as destiny," a claim which will become integral in the arguments for the Louisiana Purchase and which now apply to Trist, who seems convinced of her right to these lands (85). Trist registers this attitude on May 23: "There was a very pretty fort at this place, till about 4 years ago. It was destroy'd by the savages.... We have not yet seen any Indians, but tis thought dangerous to go on shore as they have been seen lurking about this part of the river" (Travel Diary 216.) In her depictions of the native peoples as "savages" who "lurk" about the river, she depends upon the safety of the boat to shield her from the shore. While her fears may have been justified by the still unstable treaties established between the natives and the new government, her attitudes prevent unbiased reports of the Native Americans.

In general, Trist reacts more negatively than Hamilton to the wild forces of nature and is, consequently, somewhat overwhelmed and unable to act. Hamilton takes notice of a "wild and solitary" nature, bringing him to the verge of transcendence. Where Trist imagines a future town surrounded by nature, Hamilton finds the town perched above nature just as charming if not the more inspiring. In this respect, Trist may represent the more "feminine" desire for a garden within the wilderness illustrating Kolodny's assertions that "women claimed the frontiers as a potential sanctuary for an idealized domesticity" (Land Before xiii). From this perspective, Trist appears willing to alter her environment to realize her fantasies, whereas Hamilton of ten appreciates the beauty before him in its natural state. Trist confronts a much "cruder" landscape and appears the more aggressive pioneer as she envisions and imagines the frontier as home, while Hamilton, who travels along more established roads, seems more interested in embellishing what already exists. The female adventurer is thus more directly involved with her surroundings.

Despite frustrations and dangers, Trist is confident that she can overcome any obstacle. The forests and rivers are simply temporary barriers to her goal. There is no clear sense of yielding to nature but rather a desire to transform it. ${ }^{25} \mathrm{~A}$ once forbidden wilderness may soon become a potential homestead, a cultivated garden, a plowed field, or a "pastoral dream of harmony," as Leo Marx describes it, by striking a balance between "decadence and wilderness, too much and too little civilization" ("Pastoralism" 38). Although she might appreciate the transformation, Trist is not seeking such a balance at this point. Instead, Trist casts herself as a landlady speculating on her future properties. One hundred eighty years after Jamestown, Trist looks upon the landscape not with a visitor's innocence but with an owner's imagination as she confidently assumes the pose of a potential resident. ${ }^{26} \mathrm{Willing}$ to express her fears, Trist's narrative displays a vulnerability that Hamilton's lacks, and yet her conviction appears stronger than his. In fact, Trist's briefer narrative tells the more courageous story as the assumption of ownership inspires her to imagine "improvements" and assert her faith in change. 


\section{Audience and Intention: The Trist-Jefferson Correspondence}

Perhaps her proprietor's eye is somewhat influenced by having Thomas Jefferson as an interested audience, for he was anxious to hear of potential natural resources in this new territory. As previously noted, Trist and Jefferson became acquainted in Philadelphia when he was a frequent boarder at her mother's popular boardinghouse. Whether Jefferson is anticipating his own explorations or expressing ongoing interests evidenced in his book Notes on The State of Virginia (1784), ${ }^{27}$ he seems to encourage Trist's journey. Although, as Kolodny notes, it is not certain if Jefferson "directly asked his friend to gather information for him" ("Introduction" 186-87). Whether a direct or implied request, Trist does record her impressions, and, to some extent, opens his eyes to the frontier. We do know that Jefferson was generally supportive of Trist's adventure; he writes from Annapolis on December 11, 1783, "I think you will be a distinguished creditor if you pursue your wild Mississippi scheme" (Boyd 6:383). Although Jefferson had written in an earlier letter to suggest that she postpone her journey for more favorable conditions ${ }^{28}$ he includes this kind wish in the December 11 letter: "I hope the day is near when Mr. Trist's return will make amends for the crosses and disappointments you complain of, and render the current of life as smooth and placid as you can wish" (Boyd 6:383). In the spring of 1784, when Trist and her small company have had to wait out the winter while the rivers thaw and the roads clear, she responds to Jefferson on April 8 in a long, detailed letter from Pittsburgh wherein she recounts her journey through the Ohio Valley: "I have seen many delightfull prospects from the Hills that surround the Town and yesterday I cross'd the river to the Indian side, as its call'd, to see them making sugar which is all the[y] use except Hunting. They seem to have the most delightfull soil I ever saw" (Boyd 7:87). Trist draws attention to the soil's potential and the landscape's beauty in a manner that would have appealed to both Jefferson's inquiries and her own homesteading interests.

These letters also mark the beginnings of a thirty-two-year correspondence between Trist and Jefferson, who wrote to each other from 1783 to 1815. From the eighteen surviving letters ${ }^{29}$ their correspondence appears wide ranging: they discuss family ${ }^{30}$ and friends, politics, and the frontier. They gossip and they complain, and through their correspondence, we glimpse an opening of the frontier, which for Jefferson represents expansion and for Trist promises a new home.

Comparing the letters to Jefferson with parallel passages from her Travel Diary uncovers differences in tone and emphasis. A travel narrative generally tends to be more episodic while a letter might be more reflective or philosophical. Although the male voice dominates the public document of the New Republic, the female voice speaks through the more private venues of the letter and the diary. These letters also chart Trist's attitudes toward the jour- 
ney, expressing a similar initial hesitancy that gives way to a growing enthusiasm. Before she leaves Philadelphia, she explains her concerns to Jefferson on December 8, 1783: "It is a very great undertaking for me who has never experienced any hardships to ride over the Mountains this season of the year. I expect to suffer a little but this I am.certain [sic] the fatigues of the Body can not be worse than that of the mind which I have experienced in the extreem" (Boyd 6:376). The physical hardships may distract her, but her mission of reunion will overshadow the dangers of travel. As noted earlier, Jefferson had written to Trist on December 22, 1783, with reservations about her winter departure. By the time the letter catches up with her in Pittsburgh, Trist has a more realistic understanding of her undertaking. In her April 8, 1784, response, Trist explains that although she is "not naturally gloomy minded," her present situation renders her incapable of "tranquillity":

... there is a something which I can not express that hangs about me to embitter the sweets of my life. But why shou'd I trouble my friends with my complainings. I can only plead in excuse that it [is] the greatest consolation I have and I am convinced your goodness will not suffer you to ridicule female nature. Tho an imbecility of mind is not altogether confined to our sex I must acknowledge they have less firmness than yours. If I cou'd possess a little of your Philosophy my happiness wou'd be within my reach, my mind wou'd be exalted above those trifles that at present is the sourse of my disquiets. Dash-I am done, I will change the subject. (Boyd 7:86)

The prolonged stay in Pittsburgh leaves Trist feeling displaced without her familiar domestic world, and so she seeks stability through a new perspective. While she thanks Jefferson for not ridiculing her female nature and then recognizes that "imbecility of mind" is not gender specific, Trist cannot transcend the troublesome everyday trifles of travel. Jefferson not only appears to be an empathetic audience, but Trist imagines that his philosophy can potentially exalt her by imbuing her with a larger sense of her journey, one that would allow her to tolerate the "disquiets" of the present.

The Pittsburgh letters offer an important opportunity for reflection. Four months into her journey, initial exuberance is now tempered, and Trist recognizes the strengths and limitations of her situation. In the following passage from an April 13 letter, she checks her perceptions against Jefferson's: "Whatever observations I am capabl [sic] of making I shall not fail to communicate to you but when ever I see any thing out of the common way if they are beautifull prospects my sensations are very singular I believe for I can hardly suppress the tears starting from my eyes and I am lost in wonder but a Philosophical mind like yours can gather information from all you see, account for many that appear misterious to vulgar minds and make observations as will benefit Mandkind in general" (Boyd 7:97). Apparently, observations that have a larger social value are superior to more emotional responses to the environment, as she contrasts his "philo- 
sophical mind" with her "vulgar" one. Trist thus displays a subjectivity by contrasting and evaluating two different possible viewpoints-recognizing the validity of each. Trist may not credit herself with a "philosophical eye," but she does demonstrate a discerning perspective: [January 9, 1784] "The land is fertile and capable of raising all kinds of grain. The timber is very large, and the shrubbery pretty much the same as is produced in the bottoms" (Travel Diary 212-13). Trist's domestic concerns blend here with a more empirical perspective regarding the local flora and crop yields. Although she finds her own powers wanting in this letter, many journal entries show a more definitive state of mind with explicit critiques of her lodgings and traveling conditions. Perhaps writing to Jefferson evokes a more confessional voice, for in her journal Trist appears less equivocal.

Trist's and Jefferson's friendship introduces questions about Trist's intended audience in the Travel Diary. Andrew Burstein notes that Trist was Jefferson's "sensitive, good-hearted Philadelphia friend." Jefferson often wrote to women (Trist, Abigail Adams, and Maria Cosway, among others) to share his "fanciful notions," and Burstein conjectures that they might best "understand outpourings of emotion" (65-66). Trist was one of many friends that Jefferson held dear, and the tenor of their correspondence suggests a mutual concern for each other's welfare. So when Trist includes worries over her modesty or expresses her fears, she may be either simply giving her friend a well-rounded report or trying to elicit Jefferson's protective response. By expressing such concerns, Trist's gentlewomanly persona stands as a complement to Hamilton's gentlemanly pose. In trying to ascertain her audience in the Travel Diary, one finds that Trist appears to be addressing an outside audience, such as here on May 20,1784: "In preparing for bed, I unfortunately fell from my birth [sic] backwards; bruisd my head and shoulder and otherwise hurt myself sufficient to make me a little more carefull in future. However, I got a pretty good nights rest ..." (214). Whereas in other passages, the tone and content suggest a private audience: "[June 15, 1784] ... Every one thinks their troubles the greatest, but I have seen so many poor creatures since I left home who's situation has been so wretched, that I shall begin to consider my self as a favord child of fortune" (226). Trist does engage an outside point of view by such comparisons and references, and her Travel Diary seems to acknowledge Jefferson, or at least Jeffersonian concerns. In either case, the travel narrative is a semipublic document, which assumes that even a small circle of family and friends might read it. ${ }^{31}$ More important, Trist expands its scope by integrating personal reflections with observations about her external environment.

In her Travel Diary, Trist's more public and more objective voice is most evident in her dutiful rendering of times, places, and events, as on December 27, 1783: "After breakfast we left Capt. Simpson and cross'd a very pretty creek call'd Yellow Breeches... The town much larger than I expected to see at such a distance from navigation.... I was surprised on entering the town 
to see such fine buildings" (203). Toward the end of her journey, she speculates on mineral reservoirs when she writes: "At dawn of day we left the shore and soon came in sight of the Iron bank; a great quantity of ore may be picked up on the surface of the earth. It is 16 miles from the Ohio, a fine high situation. And I am told there is to be a town laid out here very soon" (225). In her more private concerns, where her audience is less clearly defined, Trist grows confidential, such as in this entry on December 25: "Were obliged to Sleep in the same room with Mr. Fowler and another man. Not being accustom'd to such inconveniences, I slept but little" (201). Again, if Jefferson were her primary audience, her modesty might suggest that he plays the role of the confidant. Her discomfort is echoed on January 3, when her genteel standards are challenged when staying in a one-room log house that has neither floor nor windows:

I made it a rule to get up before day light that I might not see anybody nor they [see] me dress. It is customary for the Men and Women to sleep in the same room that some of the Women look upon a Woman as affected that makes any objection to it. One told me that I talk'd to upon the subject that she thought a Woman must be very incecure [sic] in her self that was afraid to sleep in the room with a strange man. For her part, she saw nothing indelicate in the matter, and no man wou'd take a liberty with a woman unless he saw a disposition in her to encourage him. (206-7)

Caught between conflicting moral codes, Trist self-consciously acknowledges the woman's criticisms about her "incecurities," which not only challenge Trist's proprieties but also casts her as a passive victim whose self-consciousness is perceived as a lack of confidence. Trist is clearly uncomfortable and unwilling to forgo her own standards and imposes her personal code despite the simplicity of the conditions. Whether or not she is writing to Jefferson specifically here, these passages show her deep discomfort with having to compromise her values in order to get a good night's sleep. In the frontier, privacy is a luxury, and Trist resists being subjected to necessity. Trist not only goes against the expectations of her community but also reveals an even deeper displeasure of her surroundings. Consistently, she would rather impose her standards than adapt to new ones. Even in such negative assertions, however, the narrative provides Trist with a clearer sense of her preferences and encourages her subjectivity, with all its own logic.

In her epistolary relationship with Jefferson, audience and content are refigured if only slightly, for Trist shares intimacies which would have been considered acceptable and in keeping with conventional expressions of friendship. If one speculates that Trist also intended for Jefferson to read her journal, it seems that she is consistently willing to reveal an internal voice to her audience and thus expresses fears and aspirations, judgments and insecurities. But more than just sharing details about her living quarters or the land- 
scape, Trist seems, at times, to use Jefferson as a reference point for how to view her experience, as she writes from Pittsburgh on April 13: "Cou'd I possibly be so happy as to have your company, my jaunt down the River might be enviable but in the present situation of affairs I dont expect much satisfaction till I arrive at my place of destination" (Boyd 7:97). The journey itself is not enough to assure Trist's contentment, for community offers the larger context for happiness. By comparing the letter to the journal, the former seems to take on the latter's role as the vehicle for self-examination as it conveys more of the confessional voice.

Her months of anticipation are unfortunately concluded in an anticlimax that befits any novel. Days before her journey is to end, she discovers that her husband had died in February while she was in Pittsburgh. And where the Travel Diary breaks off, the continued correspondence to Jefferson from the frontier conveys a profound sense of loss. On December 25, 1784, a year after she had departed so hopefully, Trist writes to Jefferson from the Acadian coast in Mississippi describing her situation and comparing it to one of his earlier letters: ${ }^{32}$

I have been severely afflicted, and my situation peculiarly unfortunate. I received the cruel stab when I least expected it. My mind was prepared for happiness, my tedious journey allmost compleated, two days more I was certain wou'd reunite me with my Dear Mr. Trist, when I received the dreadfull account of his being no more. Tho in a strange country I experienced great kindness but I wanted the consolation of my friends, and that has been denied me.... For however strong the mind may be fortified, few are proof against the shock attending such a seperation. (Boyd 7:583)

Although Trist feels abandoned and isolated, she tries to reconcile herself to this "cruel stab," as the strength of her convictions are challenged by physical and emotional hardships. Jefferson's earlier sufferings now act as a mirror for Trist's own pain as she responds both rationally and emotionally to her husband's death. She affirms that place without the companionship of family or friends is most desolate even as she writes about recovery. In her admission to a "non-reasoned" imbalance and gratitude for God's grace in restoring her, Trist's vulnerabilities are clearly expressed. Her life has been dramatically altered, and this willingness to openly assess it suggests a movement toward healing and growth and a new manifestation of her internal voice.

From this unfortunate turn, her writings redefine place as more than a physical location where her dreams for community prosperity and family happiness might manifest. Instead, the land becomes inconsequential as her mood grows melancholic. On March 12, 1785, Trist writes to Jefferson, who is now in Paris, that she has "experienced too much pain and anxiety allready in this country and every hour presents something that reminds me of my 
misfortune" (Boyd 8:24). The frontier has become desolate, for she has not the spirit nor the inclination toward communion with nature alone. Clearly unhappy about living in what she considers isolation, Trist's lack of an external audience heightens her need for an internal one, or, in Jefferson's case, a confidant. As the letter continues, it underscores the importance of familiar social contacts. The overwhelming message of this letter is that place without community is "most miserable," and she tells Jefferson: "I have no other expectation of happiness but the company and conversation of my friends. Here I am shut out from all intercourse with them. I was so long deprived of the pleasure of hearing from them that I began to think My Self the most miserable of all human beings, forgot by them all at a time when my wounded mind required the aid of friendship to sooth and allay its painful perturbation. As gloomy Ideas are ever attendant on the wretched my real troubles were constantly augmenting, by antisipating other Calamities" (Boyd 8:2425). Unlike the adventurous tone of the Travel Diary, this letter's sorrow reveals a "wounded mind" and offers a parallel to the physical dangers of her trip, for Trist now suffers psychological traumas. By refusing to succumb completely to her self-pity, she displays the strength that frontier life requires. ${ }^{33}$ Trist enlists subjectivity in its most therapeutic mode.

In these final letters to Jefferson from the frontier, the land is saturated with grief. Trist cannot dislodge her painful associations and must, therefore, leave. Only her friends can "sooth and allay" her pain; the landscape, it seems, cannot heal her. For Trist, the land is simply less alive. There is virtually no physical description of her surroundings in these letters from Mississippi. Instead, they focus on her psychological state and her desire to return to what is familiar and nurturing. Without her friends, Trist fears that she will become overwhelmed by her sorrows; her friends are an emotional anchor. And yet, remembering her intentions to inform Jefferson of the land's potential, Trist concludes this March 12, 1785, letter with these assessments:

I can not give you a very flattering discription of this country. It has been a bubble from the beginning. The poor can live in it, but there are few rich and I fancy tis the policy of the spanish government to keep people poor. The climate is not disagreeable. I have seen full as good land in my country as any on this river but I must conclude for I have not time to enter into a regular detail. You can easily find out that I am not partial to It, but no country wou'd be agreeable to me under the same circumstances that I have labourd under. (Boyd 8:26)

The land remains external to Trist, for she has neither the spirit nor the inclination toward communion with nature alone. She is not simply out for adventure and cannot set the journey outside of any context that does not include community. Instead, her connections to the country are contingent upon her emotional state, which at present renders it bleak and lonely. Aware 
of this emotional coloring, Trist withholds harsher judgment and acknowledges that she is incapable of appreciating the surrounding beauty.

The journey may have started with a specific destination and intention in mind, but as the letters illustrate, Trist has had to alter her perspective and her understanding about this trip several times. At this point, she appears adrift from all that centers and defines her, while still waiting passage from Balize, Mississippi, to Philadelphia. Her boat has unfortunately been stranded for sixteen days awaiting favorable winds. To keep her hopes up and to distract her from the delays, she maintains her correspondence. On May 4, 1785, she suddenly discovers that a nearby ship is headed for France, and so she promptly runs to her cabin and dashes off a letter to Jefferson, a letter that will hopefully arrive in Paris within the next six months. ${ }^{34}$ The letter written under these circumstances becomes part journal and part unanswered conversation as it marks time either in abstract terms by addressing large philosophical issues or in specific images that provide the correspondent with a glimpse of the writer's life. As if to apologize for any abruptness in her tone, Trist explains: "So favorable an oppertunity induces me to take up my pen to address a few lines to you, notwithstanding my situation is not the most agreeable for such an undertaking. I am evelop'd [sic] with noise and confusion." One can almost hear the commotion and imagine Trist in cramped quarters putting pen to paper as she elaborates on the difficulties of finding proper transport between the Acadian coast and her Philadelphia home since Spain now controls the territory from which she is attempting passage. Despite this animation, feelings of frustration dominate the following passage: "I have no fault to find with the country or climate or inhabitants under any other government, tho it has been the source of much sorrow to me. But a Paradise wou'd not tempt me to be seperated any longer from My dear Mother and child, since I am deprived of what cou'd only make me amends for the loss of their society" (Boyd 8:136). The lure of the frontier has vanished for now, as Trist defines its value in terms of relationship. No longer interested in merely passing on information, Trist's final letters from the frontier reveal a mature voice, enriched through having ventured and lost. And as she attempts to bolster her spirits and fill the void left by absent friends and family, she is clearly in new territory, for Trist has little precedent to draw from as a genteel woman out on the frontier. It is through her writings, therefore, that we glimpse the frontier with the reluctance of a transplanted easterner rather than the bold bragging of an explorer.

Recorded in both journal and letters, Trist offers one female's experience of frontier life. The record itself is Trist's vehicle to exercise new habits of mind. For like Hamilton, she assumes the role of a critical observer, one who is certain of her own elevated standards. As Elizabeth House Trist looks down from her saddle and out from her boat, she casts an inquisitive, critical eye and imagines the future. She neither idealizes nor romanticizes the land's beauty; 
instead, she gathers data and quantifies the frontier, leaving information about wildlife, rivers, mineral deposits, crops, towns, and inns. Unlike the promotional tracts of the seventeenth century and the Transcendental essays of the nineteenth, Trist espouses an eighteenth-century preference for improving upon nature by taming and reorganizing it. In searching for the garden, Trist does not exaggerate or mythologize the wilderness. Along with Jefferson's initial support, Trist combines the empiricism of travel literature with the dramatic narrative of the novel and offers us a literary opening of the frontier that entertains the possibilities of future growth while cataloging the immediate, everyday realities of frontier travel.

By the time of these narratives, the prospect of land ownership had been enticing migration to the New World for almost two hundred years. American identity became closely connected to both work and land: Crevecoeur sings the praises of the American farmer, Franklin champions industrious behavior, Jefferson infuses agrarian life with sacredness, and Bartram catalogs the pleasures of the gentleman hunter. The grand vision, however, of ten neglects the daily reality of traveling along country roads or transporting oneself to the undeveloped expansiveness of the frontier. For this view, Dr. Alexander Hamilton and Elizabeth House Trist have provided a more individuated lens through which we can imagine this new world. In contrast to the spiritual autobiographer, these travelers are more interested in the comforts of the next inn or the safety of the next camp than in the transformations of their spiritual state. Their texts depart from the spiritual diary by giving us a record of a physical journey distinguished by its external observations and its promotion of individual perception. The travel narrative is the genre of an expanding subjectivity that builds an awareness of difference, an awareness that is greatly heightened by the sweeping momentum of Anglo-American mobility. Travel perpetuates expansion, and the travel narrative marks its advance.

For both Hamilton and Trist, nature, social manners, Native Americans, class, and gender are all seen as fit subjects for both description and commentary. The assertions of their standards and tastes make their narratives a forum for subjective declarations. Trist and Hamilton, for example, assume that Anglo rights and ownership supersede Native Americans' rights. Although James Fenimore Cooper may have set his novels in this time period, Trist and Hamilton do not possess Natty Bumppo's appreciation of Native Americans' ways. ${ }^{35}$ Instead, their attitudes represent their times, foreshadowing the further displacement of native peoples from their ancestral homes. They also espouse prevailing eighteenth-century desires for order and control over nature and praise individual perspective for its ability to measure and quantify natural surroundings. Their narratives thus offer a barometer in which attitudes reinforce and prefigure social movement.

Hamilton and Trist anticipate real and fictional manifestations of travel where the landscape will be dramatically altered by westward migration and 
wagon trains. In Hamilton's Itinerarium with its fictionlike text and caricatures and Trist's Travel Diary with its criticisms and analysis, the travel narrative serves as a prototype for American fiction as experiences such as theirs will later be fictionalized and romanticized by nineteenth-century novelists such as James Fenimore Cooper and Catherine Maria Sedgwick. ${ }^{36}$ In sharing the common thread of the episodic travel narrative, Hamilton proves the more creative embellisher of his travels; Trist suggests future subject matter for portraying the pioneer's life. These narratives signal the increase of subjectivity in first-person narratives. As narrators of their own stories, they organize their experiences and assume some degree of control over how the material is presented. Marking the journey is justification enough for writing, and through the Itinerarium and the Travel Diary, Hamilton and Trist construct themselves as travelers through the first-person narrative. 


\section{Chapter 4}

\section{Declaring the Self in the Political Sphere: Thomas Jefferson and John Adams}

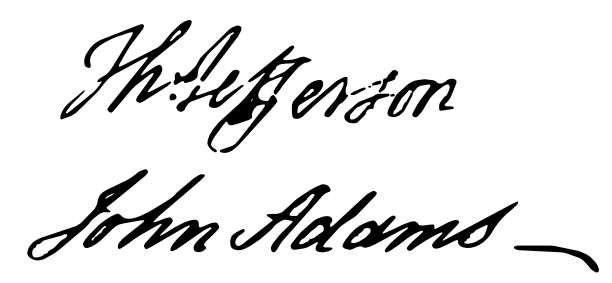

For the politician, the autobiography charts a different sort of journey, one less concerned with conversion or lodgings and one more interested in civil service and national policy. Akin to the formal memoir, with its record of military triumphs and professional accomplishments, the political autobiography broadens the memoir by including family history, early sources of inspiration, and social philosophies. With the spiritual autobiography as its forerunner, the political autobiography serves as a secular model for the aspiring social leader as it describes the evolution of its author's social and political vision. Thomas Jefferson and John Adams take on the task of autobiography primarily to oblige their families and to satisfy tradition. Although they share a common concern to set the public record straight, each author claims to be writing for his own remembrances rather than explicitly for an outside au-

Fig. 5. Thomas Jefferson's signature from a letter to Elizabeth House Trist, Poplar Forest, June 1, 1815. Poplar Forest, near Lynchburg, was Jefferson's rural retreat. (Thomas Jefferson Papers; reproduced by permission from the Special Collections Department, Manuscript Division, University of Virginia Library.) Fig. 6. John Adams's signature appears here from a letter to Charles Gravier, from Passy, France, February 16, 1779. Part 3 of his autobiography covers this period. (Reproduced by permission of The Huntington Library, San Marino, California.) 
dience. For this reason, their texts reveal the least intimate voice of the various forms of autobiography examined in this study, while they also offer the most sophisticated examples of crafting the public self.

In the Jefferson and Adams autobiographies, we find individuals who are so closely identified with their public images that the private self blends into the public self to create a rather opaque portrait. In truth, neither Jefferson nor Adams could have afforded to mark differences between a private and a public self that might show discrepancies between convictions and actions and thereby suggest a dishonest character. Following an eighteenth-century dictum that one's opinion about political issues could always change if persuaded and that one's character could only weaken given the power of political office, it was important to project a confident, forthright exterior. Rather than simply provide a chronology of events and let these events define his or her life, therefore, the political autobiographer orchestrates this act of self-representation. To some extent, of course, all autobiographers alter reality and to various degrees move the text closer to the fictional realms of storytelling, or what Betty Louise Bell calls a "fictive construct" (181). The political autobiographer guards against excessive fabrication by letting the public record serve as the setting for his or her account. External events thus appear in the text as more than convenient reference points to register an aspirant's conversion or a traveler's progress. Instead, they help define the author through his or her reactions to such events. For both Jefferson and Adams, for example, the American Revolution and the constituting of a new government figure prominently in their narratives. Borne from what Bernard Bailyn calls "the most creative period in the history of American political thought" (21), the Jefferson and Adams autobiographies demonstrate how the first-person narrative need not be self-revelatory but may, instead, exemplify the art of public performance and self-censure. ${ }^{1}$

Ultimately, these narratives offer insight into Jefferson's and Adams's readings of basic cultural values. From the selectivity of information they include, their efforts to interpret events in a particular light, even their apocryphal stories, each component represents choices made by the author which are revelatory of their cultural perspectives. With Franklin's Autobiography as a symbolic guide for presenting the "self" as a public figure, the John Adams and Thomas Jefferson autobiographies are self-promoting without being aggrandizing, self-assured without being indulgent.

\section{The Autobiographical Voice of the Enlightened Public Statesman}

As founders, Jefferson and Adams display a strong obligation to leave a record justifying the accomplishments of their remarkable times. As enlightened statesmen, they embrace the revolutionary and the experimental. Jefferson writes a hundred-page text that covers his life from 1743 to 1790 and illustrates an impassioned man with an unwavering faith in the ideals of the New 
Republic. On January 6, 1821, Jefferson begins his Autobiography with a modest statement that establishes his tone and purpose: "At the age of 77, I begin to make some memoranda and state some recollections of dates \& facts concerning myself, for my own more ready reference \& for the information of my family" (Writings 3 ). ${ }^{2}$ For Jefferson, writing about his extraordinary life is simplified to the modest task of noting "some memoranda."

Jefferson then proceeds to create an autobiographical persona that explains the personal in terms of the public. He begins with the conventional gesture of tracing his family lineage:

The tradition in my father's family was that their ancestor came to this country from Wales, and from near the mountain of Snowdon, the highest in Gr. Br. I noted once a case from Wales in the law reports where a person of our name was either pl. or def. ${ }^{3}$ and one of the same name was Secretary to the Virginia company. These are the only instances in which I have met with the name in that country. I have found it in our early records, but the first particular information I have of any ancestor was my grandfather who lived at the place in Chesterfield called Ozborne's and ownd. the lands afterwards the glebe of the parish. (Writings 3 )

Jefferson's ancestry is thus located among the earliest migrations sponsored by the Virginia Company, as just one of many immigration stories. Writing as a democratic leader, Jefferson might have been relieved that his roots are so unremarkable, and despite the relative comfort of his boyhood home at Shadwell, there is no sign here of aristocratic titles. In his understated voice Jefferson simply offers the facts of his origins, for the actions of his life will speak more forcefully than any privileging of stature. Jefferson transforms the self-examination impulse by moving out from the shadows of Puritan constraint and speaking in the first-person with authority derived from secular accomplishment rather than spiritual reflection.

In many ways Jefferson's autobiography contradicts our expectations for disclosure, and if we examine it for a confessional voice we will most likely be disappointed. Jay Fliegelman understands the frustrations of the "modern sensibility" that finds Jefferson's autobiography "irritatingly unrevealing," for Jefferson "locates his essential self in the area of civic accomplishments rather than in private life and private emotions" (Declaring 121). ${ }^{4}$ Merrill D. Peterson considers Jefferson in this way: "Few men took into account that Jefferson's private self, as expressed in his letters, might not coincide with his public self." ${ }^{\prime \prime}$ These observations place Jefferson in a particular political age wherein, as Andrew Burstein remarks, Jefferson is "highly sensitive to the complexity of living in a society preoccupied with public reputation" (53). This sense that one's public identity can be considered separately from one's private self represents a different set of expectations from today's audience that not only demands to know about the private lives of public officials but also 
views individualism in a far more autonomous manner. ${ }^{6}$ Jefferson and Adams also know that personal disclosure will be publicly scrutinized, so to avoid any undue vulnerability they appropriately establish a clear distinction between the personal and the public.

John Adams approaches writing the autobiography with caution and ambivalence, for it will force him to revisit a rather stormy public life. Although Adams begins his autobiography in 1802, he keeps the project a secret, apparently not even telling his family. When his son, John Quincy, writes two years later on November 19,1804, urging his father to record "an account of the principle incidents" of his life, John Adams responds that he is reticent to recall his "Mortifications, Disappointments or Resentments" (Adams Papers, Series I, vol. 1:lxix). Even after this plea and similar ones from his friends, Dr. Benjamin Rush and F. A. Van der Kemp, Adams never acknowledges that he is writing his autobiography (Butterfield, "Introduction," Adams Papers, $1: \mathrm{lxx})$. One of the strongest sources of motivation for his denial comes from Mercy Otis Warren, whose three-volume History of the Rise, Progress and Termination of the American Revolution. Interspersed with Biographical, Political and Moral Observations appears in 1805 and, to Adams's mind, includes such serious errors and misrepresentations that he irately refutes her ideas in ten lengthy letters (1:lxx). Frank Shuffelton finds that Warren's comments render Adams "dangerously marginalized," for they are an "aggressive and above all unfair judgment that threatens his sense of self" ("Different Voices" 294). Adams is especially disturbed by the potential for being misrepresented yet again, which motivates him to resume writing his autobiography throughout 1807 , until it suddenly breaks off in a section about the Peace Negotiations of 1780 .

From its conflicted beginnings, John Adams's autobiography grows into a 450-page diverse text with recopied diary entries and diarylike notations, correspondence, political analysis, and travel narratives. Adams's work was not formally titled Autobiography but consists of three separate headings: part 1, "John Adams," covers the period from the 1630s to mid-October 1776 and is dated from October 5, 1802; part 2, "Travels, and Negotiations," covers the period from November 1777 to July 1778 and is dated from December 1, 1806; part 3, "Peace," covers the period from September 29, 1779, to March 21, 1780, and although L. H. Butterfield explains that it "bears no date of composition," there is a reference to 1807 as the current year (1:xliv). ${ }^{7}$ At the age of sixtyseven, Adams opens his Autobiography in a tone that is both philosophical and defensive:

As the Lives of Phylosophers, Statesmen or Historians written by them selves have generally been suspected of Vanity, and therefore few People have been able to read them without disgust; there is no reason to expect that any Sketches I may leave of my own Times would be received by the Public with any favour, or read by individuals with much interest.... My Excuse is, that having been 
the Object of much Misrepresentation, some of my Posterity may probably wish to see in my own hand Writing a proof of the falsehood of that Mass of odious Abuse of my Character, with which News Papers, private Letters and public Pamphlets and Histories have been disgraced for thirty Years. (Adams Papers, Series I, vol. 3:253-54) ${ }^{8}$

A reluctant narrator, Adams acknowledges the tradition of autobiography and adds his particular need to correct any "misrepresentations" of his life story for the sake of family honor. For Adams autobiography represents a chance to exert control over a public image, and he makes no pretense toward selfrevelation. Adams does not want his record left to the interpretation of those who may abuse him, and yet he begrudges the obligation to even write one: "It is not for the Public but for my Children that I commit these memoirs to writing." As with Jefferson, it is permissible for Adams to set the record straight within the family, but these memoirs are clearly not intended for the general public. Adapting this guise allows each author to assert his viewpoint in the strongest accepted fashion. Adams affirms this intention as he offers his family's lineage:" "The Customs of Biography require that something should be said of my origin. Early in the Settlement of the Colony of Massachusetts, a Gentleman from England arriving in America with Eight Sons, settled near Mount Wollaston and not far from the ancient Stone Building erected for the double Purpose of PublicWorship and Fortification against the Indians" (3:254). Again, we are given the unremarkable beginnings of an exceptional man in an understated manner.

Adams's voice is neither intimate nor confessional as he narrates the different phases of his life. He begins part 1, "John Adams," by cataloging sequences matter-of-factly after introducing them with this disclaimer: "I shall not consume much paper in relating the Anecdotes of my Youth" (3:257). He then describes his early education: "To this School I went, where I was kindly treated, and I began to study in Earnest" (3:258); his romantic nature: "I was of an amorous disposition and very early from ten or eleven Years of Age, was very fond of the Society of females" (3:260); and his developing philosophy: "Happiness is lost forever if Innocence is lost, at least untill a Repentance is undergone so severe as to be an overballance to all the gratifications of Licentiousness. Repentance itself cannot restore the Happiness of Innocence, at least in this Life" (3:261). Although Adams's text is of ten serious, even didactic, he does make this wry comment: "I believe no Lawyer in America ever did so much Business as I did afterwards in the seventeen Years that I passed in the Practice at the Bar, for so little profit" (3:272). Adams's work ethic is admirable, and yet his complaint suggests that the economic rewards are not in keeping with individual recognition.

Having dispensed with his early life, Adams then uses the autobiography to promote his individual experience. As a lawyer might, the facts of his life are rationally presented in a logical series of causes and effects, a style which 
provides a distinct contrast to his dramatic and of ten explosive public personality. Adams appears especially guarded and protected, a reflection of what John Ferling calls "a very private person" (173) ${ }^{10}$ In fact Adams seems to discuss his life with the same detached but interested tone as he discusses literary works with his friends in the clubs and coffeehouses.

Aside from sharing their mutual burden of public life, each autobiographer speaks in a different tone, suggesting varied purposes: Jefferson's to guide and inspire; Adams's to warn and remind. Jefferson is generally more optimistic than Adams about the American people's capacity for change and renewal. From Henry Steele Commager's view, "Adams was sure that Americans would repeat all the follies and errors of the past; Jefferson was confident that they might triumph over the past" (147). Bernard Bailyn notes writing styles and finds that Jefferson has "an extraordinary gift for supple and elegant if abstract expression," whereas Adams has "a basically sensuous apprehension of experience which he expresse[s] in brilliantly idiomatic and figurative prose-but in diary notations and in letters" (16). Peterson assesses differences in letter-writing styles as a "contrast between humor and gravity." Adams's style is characterized as being "rollicking," "garrulous," and "bold," and Jefferson's style is "serious," "spare of diction," and "studied and reserved" (Thomas Jefferson 954). While Jefferson may have been more discreet and Adams more demonstrative, their writings illustrate the caution of the public statesman who tries to cast his own figure in the most positive light.

From another perspective, Philip Greven finds that degrees of self-disclosure in first-person narratives such as the diary reflect class distinctions between the evangelicals, the moderates, and the genteel. On one end, the evangelical diaries are usually "concerned exclusively with the inward self," and any record of one's actions are included if they reveal any "significance about the state of sin or grace within" (299). By contrast, Greven finds that genteel diaries are "concerned with the self in action, the outward experiences of daily life rather than the inner response to the events themselves." Adams and Jefferson are essentially genteel and, to some degree, "moderates," for they resist "personal insight or selfreflection, purposefully avoiding the confrontations with the self that were the daily experiences of evangelicals" (299). ${ }^{11}$ Appropriately, the moderate view suits the politician's need for majority appeal.

Through their writings, Jefferson and Adams also help define the role of an enlightened, democratic leader who views power itself as a potentially corruptible force. As architects of the New Republic, Jefferson and Adams vowed to prevent a resurgence of tyranny, and as founders they exercised concerted efforts in creating political institutions whose authority is carefully monitored. ${ }^{12}$ Jefferson and Adams help create a new political figure whose selfassurance is regulated by both self-examination and a system of checks and balances to temper blind ambition. In doing so, they address a key danger associated with authority identified by Fredric Bogel as "one of self-authori- 
zation, of an authority founded on nothing external to the self and its constructions" (191). Their image of leadership does not, therefore, entertain selfserving attitudes; instead, personal sacrifice and a cautious attitude toward power are evident in both Jefferson's and Adams's texts. To ensure that America would neither emulate the British system nor simply perpetuate the colonial one, personal devotion for the public good was encouraged and promoted. Public and private interests must serve one end: the country. ${ }^{13}$ They are, in sum, leaders who place public service first and personal needs second ${ }^{14}$

The ideal is often hard to uphold, as Adams conveys in a letter to Mercy Otis Warren, during more congenial times, on April 16, 1776, where he discusses the republic in terms of personal sacrifice. Emphasizing the service aspects of public life, Adams tries to reconcile the difficulties of being stationed abroad with his desires to be at home. This discussion leads him to this profile of a public servant: "There must be a positive Passion for the public good, the public Interest, Honour, Power, and Glory, established in the Minds of the People, or there can be no Republican Government, nor any real Liberty. And this public Passion must be Superiour to all private Passions. Men must be ready, they must pride themselves, and be happy to sacrifice their private Pleasures, Passions, and Interests, nay their private Friendships and dearest Connections, when they Stand in Competition with the Rights of society" (Adams Papers, Series III, vol. 4:124). Personal agendas must thus be tempered and public performance regulated. Adams defines the relationship between the governed and the governors founded upon mutual respect for serving "the public good." This interdependence requires reciprocal commitment and sacrifice, which further eradicates distinctions between the public and private.

To illustrate this understanding of public service and their identification with the public event, Adams and Jefferson include their versions of the Continental Congress, the Declaration of Independence, and the American and French Revolutions. Restating the record allows each author to control how he would like these events-and the parts they played in them-to be remembered. Adams and Jefferson not only document the development of American democratic government through these passages but also show the evolution of the self in American thought, keen to present correctly their versions of the story.

This task is particularly difficult regarding the American Revolution, since all notes about its planning had been destroyed. Adams addresses this matter in a letter to Jefferson and Thomas McKean ${ }^{15}$ on July 30, 1815, from Quincy, Massachusetts: "Who shall write the history of the American Revolution? Who can write it? Who will ever be able to write it? The most essential documents, the debates and deliberations in Congress from 1774 to 1783 were all in secret, and are now lost forever" (Adams-Jefferson Letters 2:451). On August 10, 1815, from Monticello, Jefferson responds to Adams: "On the subject of the history of the American Revolution, you ask Who shall write 
it? Who can write it? And who ever will be able to write it? Nobody; except merely it's [sic] external facts. All it's councils, designs and discussions, having been conducted by Congress with closed doors, and no member, as far as I know, having even made notes of them, these, which are the life and soul of history must for ever be unknown" (2:452). Jefferson then asks Adams: "Do you know that there exists in MS. the ablest work of this kind ever yet executed, of the debates of the Constitutional convention Of Philadelphia in 1788 [i.e., 1787]? The whole of everything said and done there was taken down by Mr. Madison, with a labor and exactness beyond comprehension" (2:453). In response on August 24, 1815, Adams deems these notes "consistent with [Madison's] indefatigable Character" and adds, "I shall never see them; but I hope Posterity will" (Adams-Jefferson Letters 2:455). This exchange suggests that the spirit of these deliberations may never be properly reconstructed, and if attempted, they must be written by those who bore witness.

This lack of documentation illustrates the larger dilemma of faithfully reconstructing the past whereby one must survey the choices and make decisions about which events to include, how to narrate them, and what message to convey. When considering these choices regarding the Revolution, Adams and Jefferson demonstrate the power of subjectivity to affect their ultimate message. Adams confronts this problem and offers an interesting alternative to Jefferson on August 24, 1815, from Quincy: "As to the history of the Revolution, my Ideas may be peculiar, perhaps singular. What do We Mean by the Revolution? The War? That was no part of the Revolution. It was only an Effect and Consequence of it. The Revolution was in the Minds of the People, and this was effected, from 1760 to 1775, in the course of fifteen Years before a drop of blood was drawn at Lexington" (2:455). By resisting the obvious, Adams shifts the focus from simply reconstructing the logistics of the battles themselves to recapturing the ground swell of passionate commitment to the cause itself. For him the Revolution is a psychological power that grew for fifteen years, during which patriots internalized its meaning almost as a sacred doctrine. The Declaration, in turn, represents the natural culmination of weeks, months, and years of debate that reflect the "Minds of the People." Given this psychological scope,Adams doubts whether the true impact of these times will be understood or valued upon recollection. For both Adams and Jefferson, the Revolution is as much a symbolic as it is an actual event that profoundly shapes their personal and political lives. For the larger community, gaining independence from Great Britain promotes individual freedom and encourages the very subjectivity that autobiography promotes.

In a similar fashion, each autobiographer includes the preparation of the Declaration as a key moment in their lives. Elizabeth M. Renker agrees that Adams and Jefferson considered their roles as signers of the Declaration of Independence as their "most enduring" roles. ${ }^{16}$ For example, Jefferson writes on Friday, June 7, 1776, "That the question was not whether, by a declaration of independence, we should make ourselves what we are not; but whether we 
should declare a fact which already exists" (Writings 15). From Jefferson's perspective, the self-evident nature of the Declaration gains momentum because it is so essentially correct, a natural consequence of events rather than an isolated, flamboyant act. Emphasizing his own identification with the Declaration, Jefferson devotes a lengthy section in his Autobiography to this document by first enumerating its premises and then presenting parallel versions of the Declaration to illustrate the political nature of the revisions. Jefferson prefaces this parallel structure with this note, "As the sentiments of men are known not only by what they receive, but what they reject also, I will state the form of the declaration as originally reported" (Writings 18). Jefferson's observation that inclusion infers exclusion is a premise that equally applies to autobiographical writing and to the construction of the self within it. Jefferson's comparison states for the historical record his initial intentions, which in many cases advocate an even greater sense of pluralism.

In the original draft Jefferson is also more specific, at times incendiary, in his complaints. For example, he includes this indictment against the king of England: "He has waged cruel war against human nature itself, violating it's most sacred rights of life and liberty in the persons of a distant people who never offended him, captivating \& carrying them into slavery in another hemisphere, or to incur miserable death in their transportation thither" (Writings 22). By setting the slave trade in this larger historical context, Jefferson associates its evils with the abuses of King George III, who has clearly mistreated the entire colonial population. In another passage that was omitted from the final draft, Jefferson connects slavery with antiquated, tyrannous notions of government, as he explains how this "clause too, reprobating the enslaving the inhabitants of Africa, was struck out in complaisance to South Carolina and Georgia, who had never attempted to restrain the importation of slaves, and who on the contrary still wished to continue it." He then chastises the other colonies for not defying the slave trade and criticizes both parties as self-interested: "Our northern brethren also I believe felt a little tender under those censures; for tho' their people have very few slaves themselves yet they had been pretty considerable carriers of them to others" (18). Although these general arguments fail to address the more profound moral and ethical implications of the slave issue, they do draw attention to the economic justifications for perpetuating slavery. Jefferson includes these omissions to reconstruct his document in the same way that the autobiography itself allows him to reconstruct his life's story. By giving his readers parallel versions of the Declaration, Jefferson suggests that the text has some responsibility to honestly illustrate the author's life. At best, autobiography demonstrates a similar faith in subjectivity.

Again, Jefferson uses his autobiography to clarify his intentions when he describes the debates over the Articles of Confederation. Jefferson notes the chauvinism of those legislatures who mask the debates with rational discourse while refusing to support a nation truly committed to democratic equality. 
He then returns to the slave issue and includes an argument by Samuel Chase, who "observed that negroes are property, and as such cannot be distinguished from the lands or personalities held in those States where there are few slaves" (Writings 25). The morality of holding slaves is ignored while the slave continues to be objectified. The issue is further debated and finally determined by economic concerns to maintain agreement between the north and the south. In a different section of the Autobiography, one addressing Virginia's history, Jefferson notes: "I have found no mention of negroes in the colony until about 1650 . The first brought here as slaves were by a Dutch ship," and to punctuate the duration of this trade, he adds, "this subject was not acted upon until the year 78. when I brought in a bill to prevent their further importation" (33-34). Although the slave trade went unchecked from 1650-1778, Jefferson acknowledges that at the very least his efforts "stopped the increase of the evil by importation, leaving to future efforts its final eradication" (34). Slavery as a moral evil is still not addressed, but the importation of slaves is halted. And while Jefferson can not imagine an integrated society, he does imagine a peaceful deportation of slaves to Africa and the eventual replacement of a white labor force: "Nor is it less certain that the two races, equally free, cannot live in the same government. Nature, habit, opinion has drawn indelible lines of distinction between them. It is still in our power to direct the process of emancipation and deportation peaceably and in such slow degree as that the evil will wear off insensibly, and their place be, pari passu ${ }^{17}$ filled up by free white laborers" (44). Including these passages allows Jefferson to clarify his participation in these debates. While he refrains from expressing his own justifications for slavery, the text does document his efforts to cease the trade. Essentially, the autobiographical text provides Jefferson an unchallenged forum, at least until his words appear in print. By inserting his version into the public record, Jefferson gives us one final word: "Nothing is more certainly written in the book of fate than that these people are to be free" (44). Looking beyond the moment, he transcends the divisive special interests that prevent the dissolution of slavery and calls on his readers to reassess these issues, using his text as a forum for national conscience.

Adams also uses his Autobiography for the purpose of revisioning the past. He corrects a false report, for example, about one of his speeches during the Second Continental Congress in a notation for Monday, July 1, 1776: "It has been said by some of our Historians, that I began by an Invocation to the God of Eloquence. This is a Misrepresentation. Nothing so puerile as this fell from me. I began saying that this was the first time of my Life that I had ever wished for the Talents and Eloquence of the ancient Orators of Greece and Rome, for I was very sure that none of them had ever before him a question of more Importance to his Country and to the World" (Adams Papers, Series I, vol. 3:396-97). Adams resists the dramatic rendering that has him asking for divine assistance and explains instead his desire for ancient skills of an eloquent orator. His version counters the apparent misunderstandings and reframes the 
context of the event itself. The autobiographical narrative thus provides a valuable service.

Jefferson and Adams may not desire to disclose private thoughts, but as they open up the texts of their lives they invite, as with any other literary work, criticism. ${ }^{18}$ At times author and text clash in a disagreeable manner, and life and authorship appear too closely paired. For example, in February of 1786, when Jefferson is in France, Adams writes to him "pressingly to join him in London immediately, as he thought he discovered there some symptoms of better disposition towards us." When Jefferson arrives in London to help negotiate trade agreements, however, he finds that the British have fused 'Jefferson-the-man with Jefferson-the-author of the Declaration, as he explains in his Autobiography: "On my presentation as usual to the King and Queen at their leveés, it was impossible for anything to be more ungracious than their notice of Mr. Adams \& myself. I saw at once that the ulcerations of mind in that mulish being left nothing to be expected on the subject of my attendance; and on the first conference with the Marquis of Caermarthen, his Minister of foreign affairs, the distance and disinclination which he betrayed in his conversation, the vagueness \& evasions of his answers to us, confirmed me in the belief of their aversion to have anything to do with us" (Writings 5758). Jefferson seems genuinely disturbed by these rude displays from the British royalty and finds their political grudge somewhat demeaning. He is especially incensed by being treated to "vagueness and evasions." The incident is helpful in illustrating the politician's problem of managing the distance between the author and the text.Jay Fliegelman finds that these attacks "identified authorship with originality" and unduly focused upon "the articulation of one's individual personality rather than one's social nature" (Declaring 165). Robert A. Ferguson considers this identification problematic, for "[a]s the Declaration itself becomes an icon of national culture, so its individual creator becomes a separate source of interest. ${ }^{119}$ By including this passage, Jefferson tries to distance himself from this identification while acknowledging that he is a formidable statesman who deserves proper treatment and respect.

In Jefferson's estimation, he should not be held personally responsible for Britain's losses, for he views the penning itself as simply part of his job: "The committee for drawing the declaration of Independence desired me to do it. It was accordingly done, and being approved by them, I reported it to the House on Friday the 28th of June when it was read and ordered to lie on the table" (Writings 17). The nonchalant tone of this passage from Jefferson's Autobiography is supported by Garry Wills's observation that Jefferson, who was away from Congress "from December of 1775 to May 13 of 1776," only arrives "[b]y accident ... in time to write the Declaration that commemorated the radicals' victory" (Inventing 32). As a sign of either Jefferson's great humility or his compulsive note taking, on the day that the Declaration passes his diary shows "an entry on the purchase of a thermometer and seven pairs of women's gloves, the amount he gave to charity, and four readings of the 
temperature" (Inventing 119). Jefferson charts his part in the revolutionary cause quite methodically, and by including his version of these incidents in his Autobiography, Jefferson can enjoy, to some extent, the last word.

Similarly, Adams briefly notes on July [4], 1776: "Resolved that Dr. Franklin, Mr. J. Adams and Mr. Jefferson be a Committee to prepare a device for a Seal for the United States of America" (Adams Papers, Series I, vol. 3:398). Adams makes other laconic entries when writing about the second Continental Congress three months earlier; the entire entry for April 3, 1776, simply reads, "[G]reat Things were done. The Naval System made great Progress." For the next day, April 4, he writes, "We did great Things again" (3:377). At these dramatic moments, one might expect more personal, introspective reactions, but Adams and Jefferson appear too preoccupied to elaborate. By contrast to a diary, the autobiography allows them this elaboration. Recollections in maturity place these events within their appropriately significant contexts.

Jefferson's discussion about the Declaration in his Autobiography, furthermore, endorses change as an enduring quality of democracy. The document itself begins with a proclamation for change: "When in the course of human events it becomes necessary for one people to dissolve the political bands which have connected them with another ... they should declare the causes which impel them to the separation" (Writings 19). The image of a "course of human events" provides a natural metaphor for the journey, path, or stream of life, so that to consciously obstruct or alter this course would provoke an enlightened audience to fight and "dissolve" such unreasonable bands. Upon acknowledging the fundamental belief in human action, the Declaration continues with assertions of "self evident" truths and instructs its audience that "they are endowed by their creator with inalienable rights; that among these are life, liberty, \& the pursuit of happiness: that to secure these rights, governments are instituted among men, deriving their just powers from the consent of the governed; that whenever any form of government becomes destructive of these ends, it is the right of the people to alter or to abolish it, \& to institute new government" (19). From this radical revisioning, governments are thus instituted among men rather than upon or over them. To go against this Declaration's argument would, indeed, be irrational. In declaring certain truths as self-evident Jefferson not only reflects his studied admiration for Bacon, Locke, and Newton, ${ }^{20}$ but the document appeals to the highest rational nature of its audience as it calls for a new social contract. ${ }^{21}$ Then, to reaffirm the balance and reasonableness of its time, the Declaration continues with this qualification: "Prudence indeed will dictate that governments long established should not be changed for light \& transient causes" (19). Change is thus grounded in rational argument rather than emotional inclination; it follows that the autobiography would chart personal change in a similar manner. As Jefferson writes about this document forty-four years later, he seems aware that it has set the standard for democratic rights in the modern world. 
Ideally, the democratic leader should inspire unity and also advocate change. For Jefferson, periodic change is stimulating, as he confides to Abigail Adams in a letter from Paris on February 22, 1787: "I like a little rebellion now and then. It is like a storm in the Atmosphere" (Adams-Jefferson Letters 1:173). Almost three decades later, Jefferson writes to Samuel Kercheval from Monticello on July 12, 1816, to discuss revisions of the Virginia Constitution and returns to this topic:

I am certainly not an advocate for frequent and untried changes in laws and constitutions. I think moderate imperfections had better be borne with; because, when once known, we accommodate ourselves to them, and find practical means of correcting their ill effects. But I know also, that laws and institutions must go hand in hand with the progress of the human mind. As that becomes more developed, more enlightened, as new discoveries are made, new truths disclosed, and manners and opinions change with the change of circumstances, institutions must advance also, and keep pace with the times. (Writings 1401)

Change should not be whimsical or unduly frequent, nor should it be resisted. Jefferson respects the process of change and marks a profound relationship between institutions and human progress. For as the people grow increasingly enlightened, government is obliged to advance and "keep pace with the times." Jefferson's model government values renewal and individual responsibility in a mutual spirit of self-examination wherein "new discoveries" and "new truths" represent a natural, logical progression.

The letter continues with a discussion of natural cycles of social progress wherein Jefferson determines that a new generation occurs "in about nineteen years" and explains to Kercheval the necessity of honoring the inevitable changes that each generation will bring to the government. Jefferson evokes an eighteenth-century sense of a natural revolution ${ }^{22}$ as in planetary motion as he writes:

Each generation is as independent of the one preceding, as that was of all which had gone before. It has then, like them, a right to choose for itself the form of government it believes most promotive of its own happiness ... it is for the peace and good of mankind, that a solemn opportunity of doing this every nineteen or twenty years, should be provided by the constitution; so that it may be handed on, with periodical repairs, from generation to generation, to the end of time, if anything human can so long endure.... This corporeal globe, and everything upon it, belong to its present corporeal inhabitants, during their generation. They alone have a right to direct what is the concern of themselves alone, and to declare the law of that direction.... (Writings 1402)

Certainly, Jefferson could not have imagined the logistical difficulties of enforcing this periodic reform. His respect for the new vision of each genera- 
tion promotes a model of government that views individual rights as essential to the health and success of the republic as a whole. Jefferson's concern with civil rights establishes an ideological basis for the emerging politicalsocial self, a concern that of ten places him in a defensive position. Harold Hellenbrand finds that Jefferson was "[a]lways suspicious of government's tendency to usurp people's prerogatives" (13). To avoid this possibility, laws and institutions must abide by this central respect for individual freedoms, as Jefferson advocates a proper balance between institutions and citizens to afford these rights.

This fundamental belief in social change lends power to individual transformation. As the governments and institutions of the eighteenth century are radically revisioned, the individual is elevated. From this new perspective, the individual speaks with a stronger sense of importance. Jefferson facilitates this revolution when he advocates abolishing primogeniture laws-land rights which secure inheritance for the first born male. Jefferson insists upon eradicating these laws in order to discourage the perpetuation of a landed gentry in America. ${ }^{23}$ Determined to establish greater land equality, Jefferson explains a plan for his home colony, Virginia: "I proposed to abolish the law of primogeniture, and to make real estate descendible in parcenary to the next of kin, as personal property is by the statute of distribution" (Writings 38). Abolishing primogeniture laws would erode the landed aristocracy by dividing estates and increasing the number of people who might own land through inheritance by making small parcels available. More symbolically, Jefferson wanted to redefine land ownership in terms of individual effort rather than family privilege; Jefferson believes strongly in this access: "The repeal of the laws of entail would prevent the accumulation and perpetuation of wealth in select families, and preserve the soil of the country from being daily more \& more absorbed in Mortmain. The abolition of primogeniture, and equal partition of inheritances removed the feudal and unnatural distinctions which made one member of every family rich, and all the rest poor, substituting equal partition, the best of all Agrarian laws" (44). Jefferson is committed to breaking this feudal structure by providing a more widely distributed access to land, with its attendant opportunity for prosperity. ${ }^{24}$ Compared with a landed economy where there is little possibility for change and certainly less possibility for upward mobility, the American socioeconomic structure promises the individual greater economic growth. Jefferson's inclusion of this discussion in the Autobiography shows how closely he connects political actions to his self-portrait. Once again, the autobiography as a political forum allows Jefferson to assert his position without the immediacy of debate and thereby exert some control over the presentation of his views.

Throughout Jefferson's and Adams's texts, they forge an image of a political figure who will not be as distant nor removed as the British or European monarchy. Instead, they define a democratic leader who will command respect while remaining close to the public. In June 1775 during the Second 
Continental Congress, Adams debates whether to establish one national government or a "Confederacy of States." By comparing "Ancient and modern Confederacies," he finds: "We had a People of more Intelligence, Curiosity and Enterprize, who must be all consulted." This new profile demands a new understanding, "for the People were the Source of all Authority and Original of all Power." Adams then admits that "[t]hese were new, strange and terrible Doctrines, to the greatest Part of the Members..." (Adams Papers, Series I, vol. 3:352). Amid these revolutionary perceptions of an intelligent, curious, and self-governing people, Adams raises questions about how their leader should act. Would he dress distinctively? What kind of protocol and address would be appropriate for these new leaders? How were they to convey honor without imposing the privileges of distinction? Careful not to duplicate the oppressive monarchy from which they had fought so hard to break away, Adams, Jefferson and the other leaders fashioned themselves with an intuitive sense of what actions befit a democratic leader. Perceived as far more paternal than a King George III or a Louis the XVI, the democratic leader would command respect and yet remain accessible. From these discussions, we glimpse a process of self-construction as Adams and Jefferson provide an ideological backdrop from which the political-social self might emerge. Opposed to a more officious or circumscribed understanding of public office, Adams and Jefferson take seriously their roles as citizens and elected leaders beholden to the public good. Ideally, they are in service to the people-a revolutionary concept.

Upon the success of the American Revolution, the possibility of democracy rallies other groups under monarchical rule to rise up, as with the French. While serving as ambassador to France in the spring of 1789, Jefferson plays yet another part on the political stage, this time as "Democracy personified." He devotes a lengthy section in his autobiography to his eyewitness reports of the French revolt, which starts by acknowledging the American Revolution as a catalyst for the French, for it "awakened the thinking part of the French nation in general from the sleep of despotism in which they were sunk. The officers too who had been to America, were mostly young men, less shackled by habit and prejudice, and more ready to assent to the suggestions of common sense, and feeling of common rights, than others. They came back with new ideas \& impressions" (Writings 62-63). ${ }^{25}$ In granting the power of change to "mostly young men," Jefferson suggests comparisons to the founders of his own country who were willing to address old questions with new insights.

These passages are Jefferson's most fluid, as he becomes part author and part character in the unfolding drama and finds himself at the center of the political scene by holding midnight meetings with Lafayette and traveling "daily from Paris to Versailles" to attend their "debates" (Writings 83). He explains the reason for his presence: "I was much acquainted with the leading patriots of the assembly. Being from a country which had successfully 
passed thro' a similar reformation, they were disposed to my acquaintance, and had some confidence in me" (85). His concern is great, for a radical change in French politics suggests great reforms in all of Europe, as he notes: "I considered a successful reformation of government in France, as ensuring a general reformation thro Europe, and the resurrection, to a new life, of their people, now ground to dust by the abuses of the governing powers" (85). The downtrodden French strike a sympathetic chord in this American citizen. And while he is proud of his influence and unique perspective, Jefferson also brings a voice of moderation to this cause: "I urged most strenuously an immediate compromise; to secure what government was now ready to yield, and trust to future occasions for what still might be wanting" (85). Thus in the first year of the constituted American democratic government, Jefferson renders his own country's reformation "successful," and in documenting a new upheaval, he enjoys his status as a revolutionary spokesman.

As with his insertion of the slave trade debates, Jefferson can not only retell history but inter ject his perspective: the slave traders are inhumane; the British lack reason; the French are impassioned. To illustrate this last point, Jefferson enthusiastically reproduces the tumultuous beginnings of the French Revolution by describing his vantage point: " $[\mathrm{H}]$ appening to be in my carriage on a visit, I passed thro' the lane they had formed, without interruption. But the moment after I had passed, the people attacked the cavalry with stones," which he explains is "the signal for universal insurrection" (Writings 89). Although it is unclear if Jefferson escapes injury because he has been recognized and, therefore, identified as a friend to the people, he does suggest that he is operating under a certain grace. These scenes are not necessarily distorted, but as captured through Jefferson's lens, the rebellion is certainly justified. If he had wanted to objectify the scene, Jefferson might have placed himself outside of the city altogether and written in the past tense. Instead, the autobiography gives him permission to set himself into the scene and cast the drama from his own angle.

Jefferson continues his narrative of the French Revolution with a profound sense of historical importance whereby the people challenge centuries of aristocratic rule. Rebellion flows through the streets with the crowd armed with farming tools and conventional weaponry causing Jefferson to forecast the demise of the king and express his contempt for the French royalty. He is particularly disgusted with the excesses of Marie Antoinette and concludes: "I have ever believed that had there been no queen, there would have been no revolution" (Writings 92). Jefferson then offers this solution to the monarchy's woes: "I should have shut up the Queen in a Convent, putting harm out of her power, and placed the king in his station, investing him with limited powers, which I verily believe, he would have honestly exercised, according to the measure of his understanding" (93). This condemnation of royal debauchery and exploitation allows Jefferson to promote his democratic, but not fully republican, sensibilities. 
Following this image of the debauched queen, Jefferson dramatizes the revolution as a battle of the morally good people against the morally corrupt leaders. His part as "Democracy" allows Jefferson to identify the flaws and imagine the necessary corrections. In this way his perceptions parallel the writing process as he uses the autobiography to edit and frame his vision. Somewhat defensively, Jefferson adds the following explanation for why he included coverage of the French Revolution "disproportioned to the general scale of [his] narrative": "I have thought it justified by the interest which the whole world must take in this revolution" (Writings 97). He claims to be serving a higher calling in his documentation of these events, but Jefferson's tone betrays his excitement. Still, he justifies his extensive coverage of the French Revolution: "I have been more minute in relating the early transactions of this regeneration because I was in circumstances peculiarly favorable for a knowledge of the truth. Possessing the confidence and intimacy of the leading patriots" (97). Retelling history thus requires trust and proximity to the truth, a similar relationship exists between the autobiographer and the text.

Unfortunately, John Adams's Autobiography breaks off at midsentence sometime in 1807 , just after he has introduced a few lines of a letter dated March 21, 1780, which prevents him from including the French Revolution among his recollections. When he does report on an equally dramatic period, the occupation of Boston during the Revolutionary War, he is similarly impassioned. Adams too dramatizes events in a theatrical manner by placing Boston at center stage; he writes to Abigail from Hartford on May 2, 1775, about a "Cause which interests the whole Globe" and describes Boston as a city under siege: "the present dreadfull Calamity of that beloved Town is intended to bind the Colonies together in more indissoluble Bands, and to animate their Exertions, at this great Crisis in the Affairs of Mankind" (Adams Papers, Series III, vol. 1:192). Adams not only expresses his anticolonial sentiments but elevates these events as symbolic of mankind's oppression and condemns all actions preventing independence as criminal. Adams shares Jefferson's identification with the political event as he too blends the personal concern with the public campaign.

From these brief examples, Adams and Jefferson communicate a distinct sense that such events as the American Revolution, the occupation of Boston, and the drafting of the Declaration reflect history in the making and include them as indelible parts of their own life stories. Viewed through their subjective lenses, these events become enmeshed in their first-person narratives as Adams and Jefferson reconstruct the world according to their own, particular visions as enlightened public statesmen.

\section{Vehicles of Disclosure: The Letter and the Autobiography}

Where the political autobiography offers a highly stylized form of self-construction, we are more likely to discover the mask lowered in the letter or the 
diary, although even then it will never be completely set aside. In that letters lend themselves easily to embellishment, one does not necessarily expect a letter to be a full accounting of the truth as much as an interpretation of events. Quite naturally, then, the letter gives rise to the epistolary novel, which lends authenticity to the fictional dramas of its characters by allowing the reader to entertain several perspectives of a singular event. The epistolary form is thus an appropriate medium for marking private concerns and offering personal, subjective interpretations. For Adams and Jefferson, who carried on a forty-nine-year correspondence with each other, the letter provides a forum for candid philosophical and political discussions. ${ }^{26}$ They began writing letters a few years after their first meeting in 1775, during the Second Continental Congress, of ten ruminating over their duties and commenting upon the intrigues of their times.

The letter provides a confidential arena, for example, when they discuss an unpleasant incident in which a note of Jefferson's is inadvertently published in an edition of Thomas Paine's 1791 pamphlet, Rights of Man, written as a defense of the French Revolution. The subsequent controversy becomes even more complex when John Quincy Adams, under the pseudonym "Publicola," publishes an attack on both Paine and Jefferson. The style of the attack itself led many to believe that the Publicola author was John Adams rather than his son, John Quincy, which causes all of their names to be "thrown on the publicstage as public antagonists" (Jefferson, Adams-Jefferson Letters 1:246).

It was well known that Adams was not fond of Thomas Paine. Adams may have agreed with the overall arguments for independence in Common Sense, but he found the supporting arguments from the Old Testament "ridiculous." As he elaborates in his Autobiography: "I dreaded the Effect so popular a pamphlet might have, among the People, and determined to do all in my Power to counter Act the Effect of it" (Adams Papers, Series I, vol. 3:331). When John Quincy Adams then publishes a counterpamphlet, Paine "hurried away to [John Adams's] lodgings" to confront the issues, whereupon Adams tells Paine that his "plan was so democratical, without any restraint or even Attempt at any Equilibrium or Counterpoise, that it must produce confusion and every Evil Work" (3:333). Although the confrontation appears to have ended congenially enough, Adams writes in 1805, fifteen years after the Publicola incident and almost thirty years after Common Sense appeared, "I perceived in him a conceit of himself, and a daring Impudence, which have been developed more and more to this day" (3:333). Much earlier, on April 28, 1776, Adams writes to Abigail about Paine: "Th is is one of the many irregular, and extravagant Characters of the Age. I never heard one single person speak well of any Thing about him but his Abilities, which are generally allowed to be good" (Book of Abigail and John 125-26). Such sentiments only fueled the misunderstandings and assumptions that John Adams was indeed Publicola.

In an exchange of letters in the summer of 1791, Adams and Jefferson attempt to clarify this complicated affair. On July 17, 1791, from Philadelphia, 
Jefferson begins by expressing his difficulty in writing about this matter: "I have a dozen times taken up my pen to write to you and as often laid it down again, suspended between opposing considerations. I determine however to write from a conviction that truth, between candid minds, can never do harm" (Adams-Jefferson Letters 1:245-46). He tells Adams that the actual note itself was so insignificant that he "did not even keep a copy of it." When one considers Jefferson's diligent practice of copying letters, not copying this particular note underlines its unimportance for him. ${ }^{27}$ Upon returning the Rights of Man pamphlet to its owner, Mr. Beckley, Jefferson explains to Adams that "to take off a little of the dryness of the note, I added that I was glad it was to be reprinted here and that something was to be publicly said against the political heresies which had sprung up among us etc." (Adams-Jefferson Letters 1:246). When the pamphlet appears with Jefferson's note at its head as a supposed endorsement, Jefferson explains that he was "thunderstruck with seeing it" and "hoped however it would not attract notice." After returning from a month-long journey, Jefferson's hopes are unfulfilled when he finds the "Publicola" response which attacked "not only the author and principles of the pamphlet, but [Jefferson] as it's sponsor, by name."

In Jefferson's determination to resolve this incident, he makes the distinction between their public and private relationship: "That you and I differ in our ideas of the best form of government is well known to us both: but we have differed as friends should do, respecting the purity of each other's motives, and confining our difference of opinion to private conversation" (1:246). Jefferson is thus aware of their different personae and wants Adams to know his concern about the preservation of distinction between the private and the public. Attempting to counter any damage, Jefferson offers this apology to Adams: "And I can declare with truth in the presence of the almighty that nothing was further from my intention or expectation than to have had either my own or your name brought before the public on this occasion" (1:246). Upon receiving Jefferson's letter, Adams seems conciliatory and responds with a sharp reprimand to the irresponsible printer "who committed this breach of your confidence" (1:247). ${ }^{28}$ Adams then reassures Jefferson that he "neither wrote nor corrected Publicola" (1:248) and affirms that he holds their friendship "very dear to [his] heart" (1:250).

In addition to portraying their mutual passion for accuracy and truth, this exchange shows their caution about communications and their desire to prevent potential misreadings, a caution which is then played out in the autobiographies. This incident also exemplifies the pressures of the public figure to account for his or her actions and words. From these letters, we observe the American politician combating misrepresentation, a continuing battle to this day. This risk of being misunderstood or misquoted prompts Jefferson to conclude this discussion with the claim that he has never submitted anything to the newspapers using a pseudonym, and he tells Adams, "I believe I never shall." 
Precisely because the letter can potentially allow the author to drop the mask of an idealized self, it is particularly vulnerable to being exposed. The Revolution intensifies the dangers of being misrepresented and teaches these leaders to be naturally guarded. In his Autobiography, Adams indicates this caution in a letter from Passy, France, on July 13, 1778, written by himself, Ben jamin Franklin, and Arthur Lee ${ }^{29}$ to a Mr. Francis Coffyn at Dunkirk which addresses this concern for accuracy: "We would wish You to observe one Rule, which is, not to write any News to America that is not well authenticated, because there are so many Misrepresentations floating about in the World, that if these should be written as they occur, to a distant Country, they would tend to confound and mislead the People" (Adams Papers, Series I, vol. 4:15960 ). They also understand that their personal correspondence is subject to publication, which as Adams explains might mislead the people.

At one especially frustrating moment, when his life proves too much in the public eye,Adams writes to his wife from Passy on December 2, 1778, and explains why he cannot be as candid as she would like: "It is impossible for me to write as I did in America. What should I write? It is not safe to write any Thing, that one is not willing should go into all Newspapers of the World.-I know not by whom to write. I never know what Conveyance is safe" (Book of Abigail and John 230). Jefferson, who is serving as ambassador to France, makes a similar apology to his friend Maria Cosway on November 29, 1786: "My letters which pass thro' the post office either of this country or of England being all opened, I send thro' that channel only such as are very indifferent in their nature." After offering her this explanation, he explains that the letters that he writes to her are not of this "character," and so he is "obliged then to wait for private conveiances" (Boyd 10:555) ${ }^{30}$ Jefferson then adds this postscript: "No private conveiance occurring I must trust this thro' the post-office, disguising my seal and superscription." The Revolution has trained them to be cautious, and given that the letter can potentially express greater candor, its security is particularly important to the author. If the letter which is meant to capture and express the writer's intimate voice is not free to do so, then the autobiography is certainly not the alternative medium, at least not for the politician.

Considering that the letter and the autobiography are each genres of selfrepresentation, it makes sense that Adams includes letters in his Autobiography to provide a more comprehensive self-portrait. Jefferson and Adams each employ these different mediums of communication for their various needs. For their public voice, the essay, pamphlet, speech, and declaration promote a certain, constructed persona. When writing to express personal thoughts, Adams and Jefferson use the letter and diary. When writing to assert control of their life's records, the autobiography offers them a sense of closure. As they each cast events and tell stories from their own subjective perspectives, their autobiographies serve as their public letters to the world. 


\section{Autobiography as a Creative Act: Sketches and Dramatizations}

The art of self-construction can also be seen in the gazettes and broadsides of the eighteenth-century, wherein authors assume the pose of anonymity. Popularized by the Tattler and the Spectator, anonymity gives the author permission to criticize government policy without suffering immediate ramifications. This pose ideally places more importance upon the words rather than the personality of the author, and, in some cases, anonymity is assumed for theatrical purposes. Franklin's Poor Richard persona, for example, bespeaks of an Everyman image that enhances audience identification with its sensible advice. In both cases, political or theatrical, the anonymous pose allows the author to experiment with character and self-construction. The supposed disinterestedness of anonymity, moreover, is partly mask and partly ploy, for it is less politically threatening to profess radical ideas under the guise of anonymity than to risk public scorn or legal ramifications. While anonymity does not necessarily imply superior wisdom, it does inspire revolutionary voices to be even bolder, as Common Sense and The Federalist Papers attest. The political autobiography modifies the anonymous voice by combining fact with subjectivity, whereupon we are given the author's individuated views. Even though Jefferson and Adams may occasionally affect the pose of a disinterested narrator, their autobiographies dramatize their lives and their nation's history.

In the Autobiography, Jefferson discusses the founding of the College of William and Mary, for instance, and breaks in with this comment: "I shall recur again to this subject towards the close of my story, if I should have life and resolution enough to reach that term; for I am already tired of talking about myself" (Writings 43). In calling his autobiography a "story," Jefferson suggests that there is more than a hint of subjectivity in his text. Jefferson is barely midway through the Autobiography at this point when he drops the mask to reveal his reluctance. Although he desires to refrain from self-disclosure, he also knows that his version of his life has more chance to avoid inaccuracies and misunderstandings than an unadorned public record. Jefferson is not necessarily being self-effacing or comical here, but he does approach his task with certain reservations. It would seem that he would rather put his ideas into action rather than on paper, which is perhaps why his most lively narrative involves the French Revolution. Generally speaking, Jefferson is rather suspicious of fictionlike embellishments, so for the more creative representations, we must look to the more flamboyant personality.

When Adams is not recopying diary entries or introducing correspondence into his autobiography, he frequently includes elaborate characterizations depicting contemporary life. At times, Adams even seems to enjoy sketching his life. For instance, in part 2, "Travels, and Negotiations," Adams notes at- 
tending the theater in France on April 27, 1778, and finds himself sitting in a box near Voltaire. Adams later records these vivid images: "The Audience between the several Acts, called Out, Voltaire! Voltaire! Voltaire! and clapped and applauded him during all the intervals. The Aged Poet on Occasion of some extraordinary Applause arose and bowed respectfully to the Spectators." Adams recounts this simple moment with a strong sense that he is recording an historical event wherein he captures Voltaire as a character in a play all his own. Adams continues with an ideal notion of how an elder statesman might be treated by an adoring public: "Although he was very far advanced in Age, had the Paleness of death and deep lines and Wrinkles in his face, he had at some times an eager piercing Stare, and at others a sparkling vivacity in his Eyes. They were still the Poets Eyes with a fine frenzy rolling. And there was yet much vigour in his Countenance" (Adams Papers, Series I, vol. 4:7778). Adams captures the moment with photographic precision and draws a realistic, compassionate portrait of this aging, still powerful, man. As his subject commands him, Adams responds thoughtfully and with finer descriptions than other sections in his text.

Adams portrays another figure, Benjamin Franklin, in a generally respectful, sometimes critical light as he pays homage to Franklin's celebrity. A particularly charming image of these two men appears in part 1 in an entry dated September 9, 1776, that describes Adams and Franklin on route to meet with Lord Howe regarding wartime resolutions and to attempt negotiations. Amid this weighty mission, they are forced to share a bed one night as Adams explains:

The Taverns were so full We could with difficulty obtain Entertainment. At Brunswick, but one bed could be procured for Dr. Franklin and me, in a Chamber little larger than the bed, without a Chimney and with only one small Window. The Window was open, and I, who was an invalid and afraid of the Air in the night <blowing upon me>, shut it close. Oh! says Franklin dont shut the Window. We shall be suffocated. I answered I was afraid of the Evening Air. Dr. Franklin replied, the Air within this Chamber will soon be, and indeed is now worse than that without Doors: come! open the Window and come to bed, and I will convince you: I believe you are not acquainted with my Theory of Colds. Opening the Window and leaping into Bed, I said I had read his Letters to Dr. Cooper in which he had advanced, that Nobody ever got cold by going into a cold Church, or any other cold Air: but the Theory was so little consistent with my experience, that I thought it a Paradox: However I had so much curiosity to hear his reasons, that I would run the risque of a cold. The Doctor then began an harrangue, upon Air and cold and Respiration and Perspiration, with which I was so much amused that I soon fell asleep, and left him and his Philosophy together: but I believe they were equally sound and insensible, within a few minutes after me, for the last Words I heard were pronounced as if he was more than half asleep.... (Adams Papers, Series I, vol. 3:418) 
Not only is the scene itself comical, but Adams creatively integrates action into his narrative along with personal asides and character dialogue. A lively portrait results in which Franklin gabs on into the night while the open window lets in cold, fresh air. Adams takes on the role of narrator in any good eighteenth-century novel which mixes the everyday, getting to sleep, with the philosophical, theories on fresh air, as these two travelers share a bed one night in a crowded tavern. ${ }^{31}$ Adams plays the role of the bemused listener, satirizing the incident with punned insults, as when he leaves Franklin and "his Philosophy together . . . equally sound and insensible." From this Fieldingesque passage, Adams reflects his milieu in fine literary fashion and proves himself as witty as Dr. Hamilton, if not cleverer.

This amusing sketch of Adams and Franklin stands in contrast to later images, especially those in part 2 that record their joint appointment as American commissioners in France two years later. Upon arrival in Paris, Adams, his son John Quincy, and a Dr. Nicholas Noel, "a french Gentleman, Surgeon of the Ship" who also served as Adams's occasional interpreter (Adams Papers, Series I, vol. 4:7), take a coach to Passy to visit Franklin. Adams notes this trip of April 9, 1778, and describes his relationship with Franklin in glowing terms: "[We visited] Dr. Franklin with whom I had served the best part of two Years in Congress in great Harmony and Civility, and there had grown up between Us that kind of Friendship, which is commonly felt between two members of the same public Assembly" (4:41). This bond exists, as Adams tells us, because of a daily interaction in both Public and Private affairs, and he concludes that in such friendships two members "always agreed in their Opinions and Sentiments of public affairs." Two weeks later, on April 21, 1778, Adams records a far less flattering portrait: "Dr. Franklin one of my Colleagues is so generally known that I shall not attempt a Sketch of his Character at present. That He was a great Genius, a great Wit, a great Humourist and a great Satyrist, and a great Politician is certain. That he was a great Phylosopher, a great Moralist and a great Statesman is more questionable" (4:69). Again, Adams shows himself as the subtle critic as he penetrates Franklin's mask just enough to keep the image alive while also inter jecting his own opinions.

Adams seems comfortable revealing gaps between Franklin's public and private self, and yet he rarely discloses any of his own faults in these passages. Instead, he plays the role of public conscience from which he judges Franklin's behavior. On April 27, Adams complains that Franklin's extensive use of the carriage prevents him from enjoying the theater: "But as Dr. Franklin had almost daily Occasion for the Carriage and I was determined the public should not be put to the Expence of another for me, I could not go so often as I wished" (4:78). One month later, on May 27, he seems even more frustrated: "The Life of Dr. Franklin was a Scene of continual discipation" (4:118). A serious man, Adams is eager to present his own life as that of an earnest and forthright public servant while he hints at Franklin's flaws and suggests a contrast. Adams draws Franklin as a character who might have appeared in an eigh- 
teenth-century novel or play. The Autobiography allows him to cast such characters in roles according to his own self-determined plan. One of the prime characters, is the author himself, John Adams, who plays the parts of author and director as he retells the stories of his life.

\section{The Democratic Leader and Refiguring the Domestic Sphere}

Examining the eighteenth-century autobiographical form for signs of selfconstruction amid these revolutionary times uncovers a new sense of individual authority. Breaking away from the parent country inspires a reexamination of familial and social structures, as fundamental cultural assumptions are challenged and reassessed. Gordon Wood observes the pervasive impact of the American Revolution on American society and finds that "social relationships-the way people were connected one to another-were changed and decisively so" (6). Helena M. Wall analyzes the subsequent refiguring of the parent-child relationship and observes that "as the relationship between parents and children tightened, the relationship between family and community loosened" (131). ${ }^{32}$ Just as political leadership is being reconstructed, profound changes also occur in the parent-child relationship.

The restructuring of both individual and political authority finds support in both Locke's sensationalist theories and Rousseau's naturalist philosophies. The refutation of innate ideas and the privileging of natural models of behavior each promotes experiential knowledge by placing more value upon the present. Parental lesson and example can thus take precedence over predetermined or past influences, and the parent assumes a more significant role in the child's education. To the extent that the New Republic itself provides a "blank slate" of opportunity, the family structure can entertain new relationships, whereby individual experience will not necessarily be in conflict with family unity. ${ }^{33}$ Fliegelman concurs that "because the mind will inevitably be formed by experience, it is essential that it be properly formed before it is corrupted by exposure to the wrong set of influences and impressions" (Prodigals 15). With the parent as a model of authority, the child intuits the process of self-construction. In addition to their political preoccupations, Jefferson and Adams were each involved in raising their children, especially with regards to education. Greven notes that, as "moderates" Adams and Jefferson would have been "concerned with the process of growth and development in their children from infancy to adulthood" (170). Considering their impact as political leaders, a brief discussion of their parenting styles supplements our sense of Jefferson and Adams as socially interested individuals.

Jefferson was especially sensitive to his responsibilities as parent, for his wife, Martha, had died four months after giving birth to their daughter, Lucy Elizabeth ${ }^{34}$ leaving him with three daughters to raise. Perhaps to compensate for his lengthy absences from home or the early death of his own father, Jefferson's strong paternal qualities manifest in structuring educational pro- 
grams for his own children and in the founding of the University of Virginia. On November 28, 1783, for example, Jefferson writes from Annapolis to his daughter, Martha, nicknamed "Patsy," who is staying in Philadelphia under the care of Mrs. Hopkinson and includes this educational plan:

from 8 . to 10 o'clock practise music.

from 10. to 1. dance one day and draw another

from 1. to 2. draw on the day you dance, and write a letter the next day

from 3. to 4. read French.

from 4. to 5. exercise yourself in music.

from 5. till bedtime read English, write \&c. (Family 19) $)^{35}$

While this curriculum is heavier on social skills than on the sciences and classics, Jefferson does seem have a moral agenda in mind. He continues by advising her to keep a regular correspondence with family and friends, Mrs. Trist among them, and to " $[\mathrm{t}]$ ake care that you never spell a word wrong. Always before you write a word consider how it is spelt, and if you do not remember it, turn to a dictionary. It produces great praise to a lady to spell well." This fatherly advice to his eleven-year-old daughter suggests expectations of great promise. There is also a hint of Jefferson's anxieties about Pasty's abilities and perhaps his absences from her, as he concludes this letter: "I have placed my happiness on seeing you good and accomplished, and no distress which this world can now bring on me could equal that of your disappointing my hopes. If you love me then, strive to be good under every situation and to all living creatures, and to acquire those accomplishments which I have put in your power, and which will go far towards ensuring you the warmest love of your affectionate father ...P. S. Keep my letters and read them at times that you may always have present in your mind those things which will endear you to me" (Boyd 6:360). Although he suggests that she has some role in achieving her own success, Jefferson notes that he has placed these potentials in her power so that to fall short is to risk his affections. One month later, on December 22, 1783, he writes with concern for Martha's social skills and proper appearance: "I do not wish you to be gaily clothed at this time of life, but what you wear should be fine of its kind. But above all things and at all times let your clothes be clean, whole, and properly put on." This advice takes on a more general tone when he adds that "[n]othing is so disgusting to our sex as a want of cleanliness and delicacy in yours" (Life and Writings 366). From such instructions, Martha's education is subject to a program that emphasizes both discipline and appearance.

Jefferson's devotion is again evident, on April 17, 1791, where he elicits Trist's advice regarding the proper clothes for his daughter, Martha, who prepares to attend the funeral of Thomas Walker Gilmer, who "had been studying medicine at Edinburgh and died soon after returning," and was the eldest son of Jefferson's friend, Dr. George Gilmer (Boyd 20:237): "Mrs. Trist has 
been so kind a s to have your calash made, but either by mistake of the maker, or of myself, it is not lined with green. I have therefore desired a green lining to be got, which you can put in yourself if you prefer it. Mrs. Trist has observed that there is a kind of veil lately introduced here, and much approved. It fastens over the brim of the hat and then draws round the neck as close or open as you please. I desire a couple to be made to go with the calash and other things" (Boyd 20:236). Jefferson's paternal concerns are evident with his insistence for accuracy and concern about the proper outcome. ${ }^{36}$

When Jefferson's parental concerns extend to his nephew, Peter Carr, he shifts his focus to a more formal, classical education. Writing from Paris on August 10,1787, Jefferson advises Peter to study Spanish over Italian as Spanish is "more useful," and he worries that Peter might confuse Italian, French, and Spanish. As Jefferson explains: "Being all of them degenerated dialects of the Latin, they are apt to mix in conversation. I have never seen a person speaking the three languages who did not mix them" (Writings 901). Jefferson also suggests that Peter study Religion, but not Moral Philosophy, for " $[\mathrm{h}] \mathrm{e}$ who made us would have been a pitiful bungler if he had made the rules of our moral conduct a matter of science" (901). This letter concludes with a passage on the value of travel wherein Jefferson remarks, "This makes men wiser, but less happy" (904). Less the father-figure and more the architect of universities, Jefferson writes to Carr years later on September 7, 1814, with his elaborate plans for the educational program that will become the foundation for the University of Virginia. The system is broadly divided into three departments: "I. Language; II Mathematics; III Philosophy" (1349). In these letters, Jefferson's parental role extends to Carr as mentor and moral advisor. Although Jefferson records little of his daily parenting duties or activities in his Autobiography, these letters suggest his desire to promote an educated governing class, a goal that inspires Jefferson as both parent and legislator.

The rising popularity of fiction, and the sentimental novel in particular, also draw Jefferson's attention, for he was suspicious of its powers of fabrication. In a letter from Monticello, March 14, 1818, Jefferson responds to Nathaniel Burwell's request for suggestions regarding the "female education" of his daughters: "A great obstacle to good education is the inordinate passion prevalent for novels, and the time lost in that reading which should be instructively employed. When this poison infects the mind, it destroys its tone and revolts it against wholesome reading. Reason and fact, plain and unadorned, are rejected. Nothing can engage attention unless dressed in all the figments of fancy, and nothing so bedecked comes amiss. The result is a bloated imagination, sickly judgment, and disgust towards all the real businesses of life" (Writings 1411). In a clear dismissal of the novel as a fanciful work that counters the development of reason, Jefferson rejects this blending of the real and the fabrication. Instead, only those novels which are "useful vehicles of a sound morality" can be valued. His list includes works by "Miss Edgeworth, and some of those of Madame Genlis.... Pope, Dryden, Thompson, Shakespeare, 
and of the French, Molière, Racine, the Corneilles," which "may be read with pleasure and improvement" (1412). Curiously, Jefferson neglects to include his favorite author, Laurence Sterne, whose novel, Tristram Shandy, explores the very issue of self-authorized individuality. When Jefferson does discuss Sterne in a letter from Paris, dated August 10, 1787, to his nephew, Peter Carr, he focuses on Sterne's moral value: "[R]ead good books because they will encourage as well as direct your feelings. The writings of Sterne particularly form the best course of morality that ever was written" (Writings 902). Paralleling his interests in experiential knowledge and education, Tristram Shandy is also concerned with childhood impressions that form the developing mind. Jefferson approves of Sterne's lessons. For the most part, however, Jefferson remains cautious about the novel's potential to distort and misguide. The same principles apply to the autobiography, as it too is subject to manipulation. Whether one reads the novel or the autobiography for moral guidance or fanciful inspiration, the author's original intentions will be subject to interpretation. Jefferson at least lets us know where he stands, and we are led to believe that reading a text for anything less than guidance and instruction is an inexcusable waste of precious rationality and, of course, time.

Following Jefferson's displeasure, fiction met with even more resistance from the rationalist ideologies of the Scottish Common Sense School that privileged a reality founded upon scientific, rational principles. Whereas such empirical influences might inspire the political arena, Emory Elliott argues that these teachings restricted "the symbolic imagination of those trained in the eighteenth-century American colleges" (Revolutionary 52). Elliott also finds that such attitudes essentially delayed the American writer from ushering in the Romantic era. Cathy Davidson agrees that these teachings negatively influenced American pedagogy by promoting "an implicit suspicion of the undisciplined imagination" which is reminiscent of earlier Puritan standards where "literature must serve clear social needs" (49). This debate over the value and worth of fiction itself carries over into the questions raised in the introduction of this study regarding the truthfulness of autobiography itself. Whereas fiction is expected to be a distortion of fact, the autobiography can be just as ambiguous. The first-person narrative may or may not be an objective, truthful retelling of events and motives. Just like the epistolary novel, it can approximate truth, which enhances and complicates the story. The desire for a true representation thus becomes less important than an interesting presentation. For these reasons, the rise of the novel and the advent of the autobiography coincide with a larger eighteenth-century interest in self-construction. And regardless of Jefferson's protestations, the greater influence of fiction upon the public consciousness could not be ignored. John Adams writes to William Cunningham on March 15, 1804, for example, and uses fictional characters to dramatize his political argument: "Democracy is Lovelace and the people are Clarissa. The artful villain will pursue the innocent lovely girl to her ruin and death. ${ }^{\prime \prime 7}$ Thus politics and art collide in this 
revolutionary period with a spirit brash enough to entertain ideas of democracy that give rise to greater individual authority.

Parallel to Jefferson's letters to his daughter, Martha, John Adams writes to his nieces in January 1761, encouraging them to consider six areas of female conduct. He includes the letter in his Diary and explains what they should know and how they should act in the following areas: "Delicacy of your own Persons and Houses," "Dress," "Elegance," "Behavior in mixed Companies," "Observations of Mankind," and "Conversation with the World." Adams advises them to be modest and moderate, and he concludes with an interesting commentary on arranged marriages and reminds them that "no Man that is free and can think, will rush blindfold, into the Arms of such Ladies, who, tho it is possible they may prove Angells of Light, may yet more probably turn out Haggs of Hell. You must therefore associate yourselves in some good Degree, and under certain Guards and Restraints, even privately with young fellows. And, tho Discretion must be used, and Caution, yet on [considering] the whole of the Arguments on each side, I cannot wholly disapprove of Bundling" (Adams Papers, Series I, vol. 1:196). From this last remark, Adams emphasizes the importance of compatibility, physical and emotional, for a successful marriage. In the spirit of enlightened discussion, Adams advises these women in areas of conduct and grants them certain rights to make intelligent choices.

In Adam's Autobiography, his parenting concerns are not as extensively articulated, but when he and his ten-year-old son, John Quincy, travel together to France, Adams does write of safety concerns. Although part 2 opens with Adams's desire to return to his "practice of the Bar" in November 1777, plans soon change. He is appointed along with Franklin and Lee as "Plenipotentiaries to the King of France" (Adams Papers, Series I, vol. 4:3), and in February 1778, Adams and John Quincy sail for France. Although this section primarily contains reports of weather and the ship's progress, he does mention his son's good behavior despite the "Chases and Tempests" and "Turbulent Weather," causing Adams to express his regret "to expose him as well as [him]self" (4:14-15). In part 3, Adams describes his second journey to France in 1779 to negotiate "Peace and Commerce with Great Britain" (4:177), and this time he brings both sons, John Quincy and Charles. There is some sense that John Quincy, in particular, is being groomed as a diplomat. In a letter written in Philadelphia on September 29, 1779, from François Barbe-Marbois, a French diplomat who had accompanied Adams on his first voyage to France, he requests that Adams brings John Quincy with him again, for he "will learn of you the means of being, one day, usefull to his Country; and your Precepts and your Sentiments will teach him to cherrish my Nation ..." (4:174). In other sections, Adams expresses concern for his sons' education and general well-being. Unfortunately, this final part is largely composed of their journey through Spain to France, and when they arrive in Paris on February 15, 1780, the remaining section is made up of letters to Congress and French 
officials, making it more of a travel narrative and epistolary record and leaving little room for personal ruminations. These passages may not be as didactic as Jefferson's letters to his young charges, but Adams appears equally invested with his parental role.

The Adams household itself was often immersed in its own upheaval, brought on in part by John Adams's frequent, extended absences. The chaos inspires some degree of domesticinnovation. For example, Abigail Adams not only manages the household but also takes on the role of political advisor, as in a letter to her husband from Boston during wartime on July 5, 1780. Abigail Adams includes both the horrors and the nobility of war and is quick to criticize the lack of a full government commitment. She also tempers a complete faith in Providence with the recognition that war itself is essentially a sorrowful event: "Our present situation is very disagreeable, it is Alarming, but perhaps not more so than you have heretofore been witness to; who ever takes a retrospective view of the war in which we are engaged, will find that Providence has so intermixed our successes, and our defeats, that on the one hand we have not been left to despond, nor on the other, to be unduely elated" (Book of Abigail and John 262). Abigail Adams is a capable war correspondent with a clear grasp of the context of each battle. The letter continues with Abigail's criticism of how the troops have been managed: "Government now see to their sorrow their deplorable mistake in not inlisting their Army during the war. Thousands of Lives might have been saved and a million of treasure. We now only patch and patch, find a temporary relief at an immence expence and by this false step give our Enemies advantages they could never have obtained if we had possessed a Regular Army" (Book of Abigail and John 263). The force of this correspondence tells us that John is a worthy recipient as she speaks in an unguarded voice and asserts the first-person with a patriot's zeal. Abigail Adams's political analysis reveals a passionate intensity whose ethical sensibilities question the value of war itself. On October 8, 1780, in a letter to John, who is in Europe, she criticizes the failure to defend Charlestown: "All hopes that I had entertained of a vigorous campaign, have been obstructed by a superior British naval force, and the daily Rumours of a reinforcement from France, rise and vanish with the day" (Book of Abigail and John 273). Abigail Adams not only challenges traditional images by questioning military strategy but also anticipates the "New Woman," who will empower the domestic sphere as a political platform. ${ }^{38}$

From their correspondence, we see a refiguring of the domestic roles as Abigail Adams takes on her own authority. On August 22, 1777, for example, she writes to her husband from Boston and provides this keen social commentary: "There has been a most shamefull neglect some where. This continent has paid thousands to officers and Men who have been loitering about playing foot-Ball and nine pins, and doing their own private business whilst they ought to have been defending our forts and we are now suffering for the neglect" (Book of Abigail and John 190). Adams is quick to evaluate and criti- 
cize wasteful behaviors, as she holds these soldiers in contempt for their lack of social service and their zeal for self-indulgence.

In the August 22, 1777, letter from Boston, for example, she makes this observation about Howe's movements: "As to How I wish we could know what he means that we might be able to guard against him," and concludes with the hope that he will never "venture" in her direction (Book of Abigail and John 190). These insights are clearly appreciated, for in her husband's September 17, 1777, reply from Philadelphia, he thanks Abigail for the "very great satisfaction ... to know from day to day the Movements of How, and his Bantitti" (192). He takes her reports seriously and perhaps counts on them to validate other information. Adams thus empowers her domestic sphere, by serving as a virtual war correspondent and skillfully manages to thrive as the head of the household while her husband is in England and France. In doing so, she contradicts gender stereotypes that, in general, "women write about the sphere of domesticity and the plot of love" (Smith 17). The female model is thus recast in the image of the self-reliant, assertive Abigail Adams.

The direct relationship between ideology and action is hard to gauge, but in these intensified times of social and intellectual questioning, Locke's call to refute innate ideas serves as a direct challenge to the past and sanctioned authority. On the individual level, the possibility of self-authorization inspires family life toward its own democratic revolution. Gordon Wood finds that "the disintegration of the traditional eighteenth-century monarchical society of paternal and dependent relationships prepared the way for the emergence of the liberal, democratic, capitalistic world of the early nineteenth century" (95). From these samples of domestic life, Jefferson and Adams represent dynamic changes as they embrace experiential knowledge and anticipate social reformation. Inspired by investigation and revolution, these patriots refigure authority and reshape family structures to reflect a greater respect for the individual voice. Their explicit parenting also reveals an activist mode of the formation of subjectivity. Realms which had been designated for divine authority are now explored within the family through the parent's new found responsibility in the age of Jefferson and Adams.

\section{Parallel Disclosures: The Letter and the Autobiography}

In a different social realm altogether, the romantic sphere, the Adams and Jefferson autobiographies are, understandably, least forthcoming. Affections are reserved for family and friends and are at best understated. For John and Abigail Adams, the letter serves as the more intimate arena for personal affections. In many of their letters, they take on pen names as "Diana and Lysander," and in others, Abigail signs herself as "Portia," the "virtuous Roman matron of history and learned woman jurist in The Merchant of Venice" (Butterfield, "Introduction," Book 4). In a typically affectionate closing, Abigail Adams expresses the poignancy of war times and the seriousness of their 
extended separation: "Good Night Friend of my Heart, companion of my youth-Husband and Lover-Angels watch thy Repose" (Book of Abigail and John 193). Their extensive correspondence documents a passionate courtship and enduring marriage. Jefferson, as the widow, however, provides a different opportunity for comparing his formal self and his private ruminations. His extensive correspondence with both male and female acquaintances contains numerous expressions of gratitude and appreciation for their friendships. And where the Autobiography gives us the formal portrait, the letter gives us the miniature.

Jefferson shields his private feelings in the public arena so well that in his private affairs he appears conflicted. The most notable example is in his fondness for Maria Cosway, painter and wife of the artist Richard Cosway, whom he met while in France as the American minister. Their friendship causes Jefferson to struggle with his affections as illustrated in the well-known "Head and Heart" letter, a twelve-page, four-thousand-word dialogue between his reason and his emotion, in which Jefferson's pain is poignantly expressed. The letter was written in Paris on October 12, 1786, upon the departure of the Cosways for England. Jefferson had suffered an accident a month earlier while walking along the Seine, where he tried to jump over a fence. Where Fawn Brodie places Maria Cosway at the scene, Andrew Burstein advances the more cautious view that the accident occurred "quite possibly in Mrs. Cosway's company" as Jefferson "vaulted a fence along the Seine and dislocated his right wrist" (78). The injury not only prevented him from ever playing the violin again, but forced Jefferson to write "slowly and awkwardly" with his left hand while he recovered.

Writing his Autobiography thirty-five years later, Jefferson only briefly alludes to the incident from a journal entry on May 24, 1787: "A dislocated wrist, unsuccessfully set, occasioned advice from my Surgeon to try the mineral waters of Aix in Provence as a corroborant. I left Paris for that place therefore on the 28th. of Feb. and proceeded up the Seine ..." (Writings 65). This section then continues with an extended account of his tour. In epistolary format, Jefferson reports this accident in various matter-of-fact tones. Writing from Paris to James Madison on December 16, 1786, Jefferson reports: "After a very long silence, I am at length able to write to you. An unlucky dislocation of my right wrist has disabled me from using my pen for three months. I now begin to use it a little, but with great pain; so that this letter must be taken up at such intervals as the state of my hand will permit, and will probably be the work of some days" (Boyd 10:602). The condition lingers as Jefferson refers to it again in a letter to Madison on January 30, 1787: "I can make not the least use of it, except for the single article of writing, though it is going on five months since the accident happened. I have great anxieties, lest I should never recover any considerable use of it" (Writings 885-86). Similarly, Jefferson writes to Elizabeth House Trist on December 15, 1786 , to explain his letter-writing absence: "The true cause of the delay has 
been an unlucky dislocation of my wrist which has disabled me from writing three months. I only begin to write now, but with pain" (Boyd 10:600). ${ }^{39}$ Thus while excluding any reference to Maria Cosway as his companion during this incident, Jefferson explains either why he has not been writing, why he was writing with his left hand, or in some cases why he was having an assistant write for him. Apparently, even his daughter, Martha, understood the accident to have occurred in the presence of a man: "He frequently walked as far as seven miles in the country. Returning from one of those rambles, he was joined by some friend, and being earnestly engaged in conversation he fell and fractured his wrist ... when, informing his companion of the accident, he left him to send for the surgeon" (qtd. in Brodie 208). Although Jefferson clearly conveys the significance of the accident as it has affected him physically, he refrains from exposing his emotional wounds. As director of his own drama, Jefferson exercises his prerogative to stage this incident from dual perspectives. Consequently, one voice renders the incident as just another event, while another voice reveals the underlying conflicts. The following letter thus explores Jefferson's psychological motivations in a manner that his other correspondence and his Autobiography cannot allow.

Alone with his thoughts and aided by a warm fire, Jefferson recounts Maria Cosway's departure from the Pavilion de St. Denis and recalls handing her into the carriage as "the last sad office." He lingers to see "the wheels get actually into motion," and then walks "more dead than alive" to meet his own carriage. From its first lines, Jefferson sets the dramatic stage and then describes his present state as "solitary \& sad," wherein he tells her that "the following dialogue took place between my Head \& my Heart." As befits his rational persona, Jefferson's Head has the first word, "Well, friend, you seem to be in a pretty trim," to which the Heart replies and the dialogue begins:

Heart. I am indeed the most wretched of all earthly beings. Overwhelmed with grief, every fibre of my frame distended beyond its natural powers to bear, I would willingly meet whatever catastrophe should leave me no more to feel or to fear.

Head. These are the eternal consequences of your warmth \& precipitation. This is one of the scrapes into which you are ever leading us. You confess your follies indeed; but still you hug \& cherish them; \& no reformation can be hoped, where there is no repentance. (Writings 867)

Casting himself as the passive, downhearted lover, Jefferson has allowed himself to be "carried home," where he promptly undergoes this internal crossexamination. The Head sees the event in terms of an inevitable cause and effect and has little hope for Jefferson's reformation. The Heart represents the subjective voice and expresses Jefferson's pain through physical and emotional sufferings. This dramatic dialogue between reason and emotion, rational and irrational parallels the distinctive aspects of Jefferson's public and private 
selves and allows him to analyze his feelings and, thereby, deliberately engage in self-construction of a dualistic kind.

Not only is Jefferson restricted by his public role to act on his private wishes, but this letter also represents the enlightened thinker's dilemma of insisting that rationality be the governing force in all matters--emotional and otherwise. Bound by this code, his response must do battle with his public persona, a response that is, at times, one of self-parody. The Heart grows defensive when the Head blames it for touring the city with Mrs. Cosway in the first place and states its case: "I never trouble myself with domes nor arches." The Heart, in fact, finds such interests a great source of boredom as it tells the Head: "But you, forsooth, who are eternally getting us to sleep with your diagrams \& crotchets, must go \& examine this wonderful piece of architecture" (868). The Head's defense lies in its criticism that if the Heart had been more rational that this "scrape" could have been avoided, and regards the Heart's motives "to prevent a separation" from its "new acquaintances" as particularly duplicitous: "Head. Lying messengers were to be despatched into everyquarter of the city, with apologies for your breach of engagement" (868).

Again the Heart is chastised for its irrational behavior. Where the Head plans the activities and preoccupations that reveal the man in public, the Heart only leads him into trouble. True, Jefferson is not usually associated with such whimsy as sending false messages to explain his absence, but this "irresponsibility" is the result of his Heart's wish for him to be with Maria Cosway rather than fulfill his official duties. In contrast, the Head's nighttime study induces sleep, a dubious virtue. Regardless of what behavior Jefferson should be following, his Heart seems to have the edge here even though the Head and Heart seem, ultimately, to complement one another as the dialogue continues. The Head aids the Heart's memory to which the Heart offers: "Retrace all those scenes to me, my good companion, \& I will forgive the unkindness with which you were chiding me." But memory is the Head's least attractive attributes, for it only seems to lead the Heart further into melancholy and irrational thoughts: "Head. Thou art the most incorrigible of all the beings that ever sinned! . . . you kindle at the recollection, you retrace the whole series with a fondness, which shews you want nothing but the opportunity to act it over again" (869). While the Heart indulges in the repetition of memory which sustains the emotions associated with them, the Head bristles at such actions. Striving for detachment, the Head remains untouched by such messy emotions and attempts to provoke the Heart's higher ethical standards, which would most likely prevent Jefferson from becoming involved with a married woman, for the Head had of ten told the Heart that "you were imprudently engaging your affections under circumstances that must have cost you a great deal of pain" (869). Unaffected by these accusations of sinful behavior, the Heart lives for the emotional moment and prefers to indulge in memory rather than to anticipate consequences. It would be difficult for Jefferson, as a leader, to allow either of these forces to reign 
supreme. In seeking a balance between sense and sentiment, Jefferson's Head and Heart should ideally work together.

As the letter continues, Jefferson focuses upon the pain of the night before the Cosways departed, when the Heart was already anticipating its agony. The Head asks that the Heart "mend your manners" as it expresses just how unpleasant being under its domain can be: "All night you tossed us from one side of the bed to the other. No sleep, no rest. The poor crippled wrist too, never left one moment in the same position, now up, now down, now here, now there; was it to be wondered at if it's pains returned?" (872). The judicious Head makes a plea for order and equipoise in the hope that the Heart will "learn to look forward before you take a step which may interest our peace" (872). Calling on Jefferson to reinstate caution, the Head reminds him of the implications of causality. The Head's accusation here that "you tossed us" indicates that the Heart has a "mind". of its own and that these two polarities operate within Jefferson in almost separate spheres.

The Head advises Jefferson to weigh all actions and consider the advantages of all acquaintances. Upon its rational scale, the Head measures such entities and then evaluates their benefit. Jefferson seems to be satirizing the social strata in which he must operate both in France and America. In trying to maneuver through this social code, Jefferson may feel the loss of his own emotional needs and considerations. The Heart also appreciates randomness for its sense of the unknown which enhances spontaneity and gives rise to emotional responses. ${ }^{40}$ Apparently, there is little room in the political arena for the kind of spontaneity that the Heart proposes. The Head, moreover, considers the long-term consequence of any action more important than the benefits of any short-term romantic encounter. Struggling with these perspectives; Jefferson negotiates a balance between his Head and his Heart.

Fearing the clouding of its judgment, the Head will not dwell in these emotional realms and continues to warn the Heart of the dire consequences of such an existence: "Head. ... Do not bite at the bait of pleasure till you know there is no hook beneath it. The art of life is the art of avoiding pain: \& he is the best pilot who steers clearest of the rocks \& shoals with which he is beset. Pleasure is always before us; but misfortune is always at our side: while running after that, this arrests us. The most effectual means of being secure against pain is to retire within ourselves, \& to suffice for our own happiness" (872). Pleasure is a corruptible force and can never be fully enjoyed because misfortune follows close behind. This call for repression, furthermore, assumes life is an art, a deliberate construction in which avoidance of pain is preferable to embracing of pleasure. Upon asserting this argument against the dangers of emotion, the Head revels in its praise for "the inestimable value of intellectual pleasures" to lead them both into more "serene \& sublime" realms. With the Head's praise for the sublime, its case is almost convincing until it adds this proclamation: "Friendship is but another name for an alliance with the follies \& the misfortunes of others. Our own share 
of miseries is sufficient: why enter then as volunteers into those of another?" (872-73). Even the dourest preacher might object to such a rejection of social charity, as the Head expresses disdain for the untalented who dwell among the "bustle and tumult of society." Indeed, what irony this elitism expresses, both because of the pending French Revolution and because Jefferson himself embodies democracy. Taking the Head's intellectual reverie to its heights, society would certainly suffer a distinct break between those of finer and grosser sensibilities. This noncharitable view of humanity not only would have offended the more sentimental Goldsmithians of the day but also scorns emerging Romantic sensibilities that demonstrate empathy toward the underprivileged. Jefferson's Enlightenment sentiments are thus epitomized in the absolute rationality of the Head, who asserts that reason should prevail over emotion.

The Heart then responds, first to the Head's condemnation of friendship with its own natural imagery: "But friendship is precious, not only in the shade but in the sunshine of life; \& thanks to a benevolent arrangement of things, the greater part of life is sunshine" (873). Countering the Head's persuasive speech on the virtues of intellectual pursuits that would provide the self-control it apparently lacks, the Heart offers its own definition of the sublime: "And what more sublime delight than to mingle tears with one whom the hand of heaven hath smitten!" The Heart then pleads with the Head to embrace humanitarian sentiments by appealing to its sense of duty and social responsibility:

Heart. ... Let the gloomy monk, sequestered from the world, seek unsocial pleasures in the bottom of his cell! Let the sublimated philosopher grasp visionary happiness while pursuing phantoms dressed in the garb of truth! Their supreme wisdom is supreme folly; \& they mistake for happiness the mere absence of pain. Had they ever felt the solid pleasure of one generous spasm of the heart, they would exchange for it all the frigid speculations of their lives, which you have been vaunting in such elevated terms. Believe me then my friend, that this is a miserable arithmetic which could estimate friendship at nothing, or at less than nothing. (873-74)

Ridiculing the Head's earlier assessment of friendship in measurable terms, the Heart admonishes such judgment and praises, instead, the power of emotions. Uninterested in seclusion and elite posturing, the Heart also prefers the open sunlight of life to the darkness of the monk's cell and likewise denounces the "sublimated philosopher" whose analytical mind limits the ability to respond emotionally to "the solid pleasure of one generous spasm of the heart." The Heart advocates an awakening of Jefferson's emotions despite the restrictions placed upon his relationship with Maria Cosway. Through romantic images wherein nature reflects human emotion, it is Maria Cosway who causes the earth to glow with the reflection of her beauty. 
Unfortunately for his Heart, Jefferson's public image calls for such emotions to be as sequestered as those of the monk and as sublimated as those of the philosopher. The Heart then displays its own reasoned understandings as it explains to the Head: "When nature assigned us the same habitation, she gave us over it a divided empire. To you she allotted the field of science; to me that of morals ... in denying to you the feelings of sympathy, of benevolence, of gratitude, of justice, of love, of friendship, she has excluded you from their controul" (874). Thus the Heart asserts its power, and before the letter returns to its more traditional format, the Heart delivers a stinging condemnation of a world in which only the Head's dominion might prevail: "Heart. ... If our country, when pressed with wrongs at the point of the bayonet, had been governed by it's heads instead of by it's hearts, where should we have been now? ... we supplied enthusiasm against wealth and numbers; we put our existence to the hazard, when the hazard seemed against us, and we saved our country. ... I do forever then disclaim your interference in my province" (875). Banishing his Head from his Heart's "province," Jefferson expresses his relationship to American politics in these passionate terms. Accordingly, the Revolution was won because the Heart triumphed over rational discourse which would have discouraged the revolt in the first place. In a closing passage, the Heart has the last word and makes one final criticism of the Head's priorities: "Notwithstanding your endeavors too to damp my hopes, I comfort myself with expectations of their promised return. Hope is sweeter than despair, \& they were too good to mean to deceive me" (876). Praising his friends, the Cosways, Jefferson's Heart asserts its triumph over his Head and claims to be fully aware of the consequences of his actions. For the Heart, friendship and love are worth their price.

The letter's analytical discourse incorporates predominant Enlightenment sensibilities and anticipates Romantic sentiment. Jefferson casts this dialogue between seemingly irreconcilable opposites that are allocated to different provinces to perform different tasks. The associations are also gendered as the Heart reigns over the female-identified emotional realm while the Head manages the male-identified rational arena. The notion that these realms exist in polarity allows Jefferson to put on the mask of theatrical projection without fully assuming either role, suggesting that these forces remain more embattled than harmonious. The twelve-page epistle ends with mentions of the weather, greetings to Mr. Cosway, and final supplications to Mrs. Cosway. Jefferson then goes on with the business of his life. The letter's self-indulgent dialogue offers the epitome of the conscious construction of the self; one might even consider it a deconstruction. Regardless of his inability to act fully upon these heartfelt impulses, this letter parallels the deliberateness of his self-presentation in the Autobiography itself, in which there is no excessively emotional voice but, rather, the voice of balance and order. The official record thus favors a voice which is careful to advance an image of a rational, contemplative leader. 
The autobiographies of Thomas Jefferson and John Adams demonstrate the power of first-person narrative to craft self-presentation. Jefferson and Adams know that their lives are public property, and so they sculpt the written word to their advantage. Similar to Franklin's enumeration of his erratum, the autobiography also offers Jefferson and Adams a second chance to correct any inaccuracies which have entered the public record. As the confessional meets the political, the autobiographical voice can restate intentions, justify decisions, and resurrect visions. For when the political figure engages in self-examination, he or she remembers original intentions and idealistic goals. Momentarily, the politician speaks without the immediate challenge of debate while he or she lays out the progression of a political life.

In the Jefferson and Adams texts, first-person narrative as a deliberate vehicle for self-construction finds its strongest expression of the two other forms examined in this study. For unlike both the spiritual autobiography and the travel narrative, the political autobiography combines philosophical and secular points of view as the author narrates a life illustrated through the literary techniques of storytelling, the social act of parenting, and the political role of president and leader. Adams and Jefferson blend these components with the understanding that their lives may offer insight or guidance, and, in this respect, their intentions more closely parallel those of the didactic spiritual autobiography and the instructive travel narrative. Yet unlike its forerunners, the political autobiography has the potential for more immediate and widespread consumption. In this respect, the political autobiography anticipates the celebrity autobiography of today, which is read for information, inspiration, or pleasure with the assumption that the reader will learn something private and personal, providing insight or a sense of finding out the "inside" story. But as with Jefferson and Adams, the illusion of intimacy is well rehearsed, for the public figure can hardly afford to display the vulnerability of the spiritual autobiographer, nor assume the candid opinions of the travel narrator. Instead, the political autobiographer writes as a public figure who will be publicly scrutinized.

In tracing the development of the subjective narrative, the political autobiography draws on more varied material from the author's life in constructing the self. For Jefferson and Adams, autobiography is not necessarily a confession or a sign of personal disclosure, nor is it merely a recitation of places and events; it is instead a carefully crafted vehicle for tracing self-construction in the first-person narrative. 


\section{Conclusion}

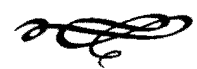

To take up pen and commit one's life story to paper involves an act of selfexamination and self-construction. In this autobiographical act, the degree of self-disclosure distinguishes the type of autobiography. Spiritual autobiography reveals an individual's weakness in order to affirm the transformation of conversion. The travel narrative illustrates an individual's curiosity and affirms the knowledge gained by observation. Political autobiography reinforces an individual's judgments and affirms the power of conviction. The eighteenth-century narratives in this study mark these differences and signal a transformation in the first-person narrative. Common to these genres is the impulse to know the self and to examine the consequences of this knowledge. From the colonial community to the New Republic, the desire to reinvent cultural paradigms based upon democratic principles manifests in all aspects of American life: spiritual, social, political. To read these narratives in relation to these changing paradigms is to study an increasing subjectivity and to witness a growing appreciation for the individual's voice.

Eighteenth-century autobiographical writings also mark the period as more than just a post-Puritan or pre-Romantic interlude. Instead, these writings express the inspired curiosity of the eighteenth century. Desiring to know about the next town, the new arrival, the latest technology, the recent tract, the native flora and fauna, these writers celebrate this land with a sense of belonging and ownership. Aware of the opportunities associated with independence, there is a release of energies in these writings and an assertion of the authorial right to refigure one's life through the first-person narrative. As Jefferson's Head-Heart epistle suggests, the outcome of such dialogue matters. Ashbridge and Edwards strive toward spiritual investigation; Hamilton and Trist encourage travel and exploration; Jefferson and Adams inspire social conscience as they protect individual reputation.

From their voices, we begin to see that the Republic was not built by a set of engineers but emerged from personal declarations of self. Invigorated by 


\section{Conclusion}

their choices in a social-political climate that reveres the individual in proper respect to the Republic, these authors attempt to negotiate a balance between self-interest and community interest, a concern that contradicts more recent expressions of self-interest for the mere sake of self-gain. Self-interest devoid of social context seems a strange aberration of the original impulses that were tied to promoting social good. By contrast, these writings express a revolutionary spirit that is neither cynical nor despairing, and their shared conviction about the bond between self and community inspires the individual.

This study thus suggests a point of departure for examining the eighteenth century not simply as a period of little fiction but as a period of intense communication. These writers are part of a bustling colonial period, one that began in the midst of spiritual awakenings and ended as a young, independent democracy. They show us a new world, one in which articulating the self through self-examination leads to self-construction. From Hamilton to Adams, the first-person narrative encourages subjectivity through observation and evaluation. From Ashbridge to Trist, writing about the self leads to new expressions of female authority. From Edwards to Jefferson, autobiographical writing is based upon contemplative self-examination. Engaged in the process of self-knowing and immersed in the creation of a new social order, Ashbridge, Edwards, Hamilton, Trist, Adams, and Jefferson project their voices out onto the landscape, the garden, the congregation, the assembly, and the meeting hall with a confidence borne of self-examination and culminating in self-construction.

The diversity of their motives is mirrored in the variety of their origins. Edwards, Trist, Jefferson, and Adams are all descendants of a people who, whether spiritually or economically motivated, relocated for the sake of improving their lot. Ashbridge and Hamilton are newly arrived immigrants who share a desire to investigate their surroundings. Edwards and Ashbridge build upon a legacy of spiritual mission and witness a growing tolerance for religious expression. Their narratives illuminate the spiritual quest with distinctive, personal voices. Trist and Hamilton expand upon the exploration narrative as they too value the possibilities of free enterprise and are inspired by the expanding possibilities for mobility. Adams and Jefferson recall voices from both the Plymouth Plantation and the Massachusetts Bay Colony by demonstrating a new passion for reformation. Their autobiographies articulate the distinctive persona of a democratic leader, a new invention altogether. These authors have inherited a respect for self-examination that encourages them to evaluate themselves and to appreciate their perspectives. In their writings, subjectivity is valued and diversity is celebrated.

The declarations of self in these autobiographical narratives are powerful. Elizabeth Ashbridge states this intention: "I desire that whosoever reads the following lines, may take warning and shun the Evils That I have thro' the Deceitfulness of Satan been drawn into" (147). Jonathan Edwards makes this resolution: "I made seeking my salvation, the main business of my life" (82). 
Dr. Alexander Hamilton makes this proclamation: "Tho I am no free mason myself, I could not agree with this gentleman, for I abhor all tyrannical and arbitrary notions" (190). Elizabeth House Trist views her surroundings: "Upon the whole, I like the situation of Pittsburg mightily and, was there good Society, I shou'd be contented to end my days in the Western country" (213). John Adams writes: "I dreaded the danger of disunion and divisions among Us, and much more among the People"; "I was determined to take a Step, which should compell them and all the other Members of Congress, to declare themselves for or against something. I am determined this morning to make a direct Motion that Congress should adopt the Army before Boston and appoint Colonel Washington Commander of it" (Adams Papers, Series I, vol. 3:314, 322). Thomas Jefferson asserts: "I proposed to abolish the law of primogeniture"; "I have been more minute in relating the early transactions of this regeneration because I was in circumstances peculiarly favorable for a knowledge of the truth" (Writings 38, 97). Through these declarations, the first-person voice rings strong.

This self-declared authority flourishes in the autobiographical writings of these eighteenth-century authors. The era of revolution was one that empowered individual expression. Would Elizabeth Ashbridge have ventured away from her unforgiving father and limited social prospects if this new place, America, had not captured her imagination? Would Jonathan Edwards have been willing to walk in his father's garden and call out his lamentations as unselfconsciously as he does if he were not living in an atmosphere that reverenced personal revelation? Would Elizabeth Trist have traveled into unknown territories with the same enthusiasm? How could Dr. Hamilton have enjoyed the freedoms of travel without the aid of the expanding network of colonial roads, or the liberty for commentary upon fellow citizens without the hurly-burly of a growing democracy? Would Thomas Jefferson and John Adams have been able to persuade a colony of once-loyal subjects to break free from their subordinate stature unless the people themselves were charged with the spirit of change? Indeed, Jefferson and Adams themselves are inspired by the grandeur of possibility wrought by their revolution. These narratives have been energized by exploration and expansion. Boundaries have been tested and redrawn, which has allowed the individual to imagine new possibilities of self-expression.

The pairings of these authors have also prompted comparisons based on class and gender. The bravery of Ashbridge and Trist, notable by any standard, is nevertheless restricted by a culture that grants greater freedoms to men. Ashbridge must overcome the protestations of virtually every male authority in her life in order to pursue her spiritual goal. But unlike women in most periods of history, she does so. By contrast, Edwards enjoys support and encouragement from his family. Trist journeys through unfamiliar territory on horseback and overcomes her fears. Hamilton travels leisurely about New England as a privileged gentleman who can enjoy a calmer landscape and 
the acceptance of a largely male network of clubs and coffeehouses. Although Ashbridge and Trist may experience more restrictions, their narratives legitimize the domestic as a source of powerful female vision. All of these authors are privileged by their race and class, which allows them the mobility and social access they enjoy. Their complaints, however justified, cannot compare to the inequities experienced by the black and Native American peoples who share these lands. While an appreciation for these writings can be easily overshadowed by the fact that there were many others whose rights were not addressed, their greater value lies in their hopefulness and optimism for the potential of individual expression.

In a very different society, where the dream of widely shared individual rights is more nearly realized, we share a common ground with these writings. We are still engaged in self-examinations that lead to new possibilities of self-construction. From these eighteenth-century beginnings, we see that autobiography is a collection of subjective impressions and interpretations where self-examination inspires the self-knowledge that makes self-construction possible. The impulse to know the self pervades the six unique first-person narratives included in this study. Through their various constructions, they share the conviction that the individual's story is worth telling, and as we read, we hear their "Declarations of Independency." 


\section{Notes}

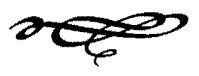

\section{Introduction}

1. In an elaborate discussion on John Calvin and election, Larzer Ziff makes this observation: "Whereas it is true that he who is saved will behave graciously, it is not true that seemingly gracious behavior is a sound sign of salvation. Rather, the soul must be searched for such signs, and the search is ultimately verbal." See Puritanism in America: New Culture in a New World (New York: Viking, 1973), 28.

2. Richard Slotkin identifies this Puritan view as "the individual experience as community experience in microcosm." See Regeneration Through Violence: The Mythology of the American Frontier, 1600-1860 (Middletown, Conn.: Wesleyan Univ. Press, 1973), 39.

3. Michael Zuckerman describes the scenario in this way: "[E]ven as people pursued social solidarity, they persisted in the dream of freedom that had first lured them. Even as they ached for order, they yearned for autonomy." See "Identity in British America: Unease in Eden," in Colonial Identity in the Atlantic World, 1500-1800, ed. Nicholas Canny and Anthony Pagden (Princeton: Princeton Univ. Press, 1987), 138.

4. Stephen Foster elaborates on the Puritan tendency to set "the committed apart from the body of their countrymen." See The Long Argument: English Puritanism and the Shaping of New England Culture, 1570-1700 (Chapel Hill: Univ. of North Carolina Press, 1991), 18.

5. Philip F. Gura explains the settling of New England as the "fulfillment of biblical prophecy, a land in which the life of the spirit informed all behavior and so would mark the spot of the New Jerusalem." See A Glimpse of Sion's Glory: Puritan Radicalism in New England, 1620-1660 (Middletown, Conn.: Wesleyan Univ. Press, 1984), 13.

6. Helena M. Wall is possibly referring here to Gura's chapter, "Puritan Ideology: Inherent Radicalism," in Gura, Glimpse of Sion's Glory, 155-84.

7. Patricia Caldwell notes that in the 1650s in England "many of the worst fears of the moderates were coming true: Ranters, Antinomians, Quakers, and 
sectaries of all sorts seemed to be putting man in the room of God and doing so by appealing to dreams, visions, voices, and personal revelations. 'Extraordinary' experience began to be seen as an insidious means to uphold the authority of the self over both civil and ecclesiastical restraints and even over the objective revelation of the Bible-a particularly dangerous and subversive delusion." See The Puritan Conversion Narrative: The Beginnings of American Expression (Cambridge: Cambridge Univ. Press, 1983), 16-17.

8. When spiritual practices invite individuals to refigure their relationships to the church, there is also a potential for social change. In the epilogue of Glimpse of Sion's Glory, Gura remarks that "no one has yet detailed the connections between this radicalism [of the Great Awakening] - particularly the American patriots' powerful antiauthoritarianism and their millennial aspirations - and the tradition of seventeenth-century American radicalism" (327). While this study does not imagine to answer this challenge, it attempts to elaborate on these connections.

9. Emory Elliott documents such a change: "In the funeral sermons of the early eighteenth century there is also evidence of a shift of interest away from the communal group and toward the individual." See "The Development of the Puritan Funeral Sermon and Elegy: 1660-1750," Early American Literature 15 (1980): 157. He also provides this valuable perspective: "Discussions of Puritan literature must acknowledge that no single monolithic interpretation of Puritan history exists and that every statement one makes about the subject involves a choice among several competing, but not necessarily contradictory, interpretations." See "New England Puritan Literature," in The Cambridge History of American Literature, vol. 1, 1590-1820, ed. Sacvan Bercovitch (New York: Cambridge Univ. Press, 1994), 184.

10. For a discussion on the efforts of Puritan theology to "externalize and systematize this subjective mood," see Perry Miller, The New England Mind: The Seventeenth Century (Cambridge: Harvard Univ. Press, 1954), 5.

11. Barry Alan Shain reminds us that "individualism would be one of the least useful ways of describing [eighteenth-century] America." See The Myth of American Individualism: The Protestant Origins of American Political Thought (Princeton: Princeton Univ. Press, 1994), 84. Kathleen M. Swaim, in turn, notes that the Puritans "would have worried about rather than approved even such minimal clues to identity as we have discovered." See "'Come and Hear': Women's Puritan Evidences," American Women's Autobiography: Fea(s)ts of Memory, ed. Margo Culley (Madison: Univ. of Wisconsin Press, 1992), 45.

12. In her study, Wendy Martin explores this aspect of Anne Bradstreet's poetry in greater detail, especially in chapter 5, "Were earthly comforts permanent.'" See An American Triptych: Anne Bradstreet, Emily Dickinson, Adrienne Rich (Chapel Hill: Univ. of North Carolina Press, 1984), 67-76. 
13. Certainly, such subordination was expected of women, slaves, Native Americans, and children. For in truth these same voices are still underrepresented, as it has only been recently-in the past twenty-five years-that significant changes and additions have been made to the literary canon itself. For an articulate gender study of Puritanism, see Ivy Schweitzer, The Work of Self-Representation: Lyric Poetry in Colonial New England (Chapel Hill: Univ. of North Carolina Press, 1991).

14. According to an extensive study by Virginia DeJohn Anderson, "[b]etween 1630 and 1640, over 13,000 men, women, and children boarded the crowded ships that would carry them to Massachusetts's shores." See New England's Generation: The Great Migration and the Formation of Society and Culture in the Seventeenth Century (Cambridge: Cambridge Univ. Press, 1991), 15. Philip Gura estimates that between 1630 and 1660 approximately twenty thousand colonists settled in New England (Glimpse of Sion's Glory 4). And according to Gordon Wood, between 1764 and 1766, "125,000 entered the American colonies from the home islands." Wood specifically cites New York's population as jumping from 80,000 to over 168,000 between 1761 and 1771 . From 1760 to 1776 , Wood claims, there were 264 new towns established in northern New England. See The Radicalism of the American Revolution (New York: Knopf, 1992), 125-27.

15. According to Sacvan Bercovitch, "The tradition of humanist personal literature, extending from the fourteenth through the seventeenth centuries ... is concerned exclusively with the autonomous secular self." The author thus "assumes that what he has done will interest others because it is authentically his, the product of his own personality in all its rich uniqueness. The model of identity he offers posits that no two selves are alike." See The Puritan Origins of the American Self (New Haven: Yale Univ. Press, 1975), 11-12.

16. Michael Walzer finds that "Puritan ministers wrote and preached with an intense awareness of an audience," which suggests one way in which this literature avoids self-indulgence and maintains standards of conformity. See The Revolution of the Saints: A Study in the Origins of Radical Politics (Cambridge: Harvard Univ. Press, 1965), 144.

17. In Emory Elliott's discussion of personal narratives, he explains this dynamic as the "spiritual journey of a single soul became a community drama that served as a paradigm for the plight of the congregation just as the wellbeing of the congregation was reflected in each member." See "New England Puritan," 205.

18. The social and spiritual covenants were inextricably connected. And as Michael Walzer reminds us, a good Puritan leader took his role seriously and considered it "derived from the conception of the official as an instrument of God." See Revolution of the Saints, 262.

19. Quotations from Abigail Adams and John Adams, The Book of Abigail and John:Selected Letters of the Adams Family, 1762-1784, ed. L. H. Butterfield, 
by the President and Fellows of Harvard College (Cambridge:Harvard Univ. Press, 1975) have been reprinted by permission of Harvard Univ. Press.

20. Frank Lentricchia regards " $t$ the central commitment of historicists, old and new, is to the self as product of forces over which we exercise no control-the self as effect, not origin. ..." See "Foucault's Legacy: A New Historicism?" in The New Historicism, ed. H. Aram Vesser (New York: Routledge, 1989), 241.

\section{Chapter 1. From Self-Examination to Autobiography}

1. See Elizabeth W. Bruss, Autobiographical Acts: The Changing Situation of a Literary Genre (Baltimore: Johns Hopkins Univ. Press, 1976), 7. Robert Sayre concurs: "The coinage was put into circulation by Robert Southey in The Quarterly Review only in 1809." See The Examined Self: Benjamin Franklin, Henry Adams, Henry James (Princeton: Princeton Univ. Press, 1964), 4.

2. Barry N. Olshen's term "autobiographical persona" is especially helpful in discussing how self-examination and the confessional begin to merge. See "Subject, Persona, and Self in the Theory of Autobiography," a/b: Auto/Biography Studies 10 (1995): 5-16.

3. Paul John Eakin notes that "the unconscious has its own associative version of the self's history." See "Narrative and Chronology as Structures of Reference and the New Model Autobiographer." In Studies in Autobiography, ed. James Olney (New York: Oxford Univ. Press, 1988), 34. Sidonie Smith elaborates by noting that "autobiography becomes both the process and the product of assigning meaning to a series of experiences, after they have taken place, by means of emphasis, juxtaposition, commentary, omission." See A Poetics of Women's Autobiography: Marginality and the Fictions of Self Representation (Indianapolis: Indiana Univ. Press, 1987), 45.

4. Similarly, Constance Jordan finds that "[a]llowing for cultural determinants also dispels the illusion that the act of reading is a discovery of what is, objectively, in the text. For what seems to be in the text is actually a meaning that the reader-who is also, in a sense, a text-selectively determines by a whole set of interpretive decisions." See the introduction to PMLA 106 (1991): 1037.

5. Shari Benstock describes the act of " $[\mathrm{w}]$ riting the self" $f^{\prime \prime}$ as a "process of simultaneous sealing and splitting that can only trace fissures of discontinuity" (29). Moreover, she mistrusts the autobiography which attempts "to seal up and cover over gaps in memory, dislocations in time and space, insecurities, hesitations, and blind spots," and cites Augustine, Rousseau, Jefferson, and Henry Adams as examples of such writers as they "do not admit internal cracks and disjunctions, rifts and ruptures" (20). In turn, Benstock questions the intention of the autobiography itself: "[W]hat 
begins on the presumption of self-knowledge ends in the creation of a fiction that covers over the premises of its construction" (11). See "Authorizing the Autobiographical," in The Private Self: Theory and Practice of Women's Autobiographical Writings, ed. Shari Benstock (Chapel Hill: Univ. of North Carolina Press, 1988).

6. Regarding eighteenth-century literature and philosophy, Stephen Cox notes: "Nothing is more common ... than the search for the 'true self,' a self that is often rather conveniently regarded both as an individual's 'real' identity and as the principle from which he can derive the greatest moral significance." See "The Stranger Within Thee": Concepts of the Self in Late-Eighteenth-Century Literature (Pittsburgh: Pittsburgh Univ. Press, 1980), 7.

7. Lejeune advises those who are interested in gaining a more objective portrait to investigate the pre-texts which will allow the reader to "study in vivo the psychological mechanisms of memory, and the way the building of a self-image evolves through time, and according to the destination of the text." See "The Genetic Study of Autobiographical Texts," Biography 14 (1991): 3.

8. Patricia Meyer Spacks elaborates on the relationship between factual and fictional elements in autobiography: "[T] he writer obviously selects among his memories and shapes them to his purposes. Events in autobiography, then, do not create character in the same way as events in fiction. Yet one may feel that the central character of an autobiography has created a self, then written the book to validate the creation. The writing itself may constitute the creation." See Imagining a Self: Autobiography and Novel in Eighteenth-Century England (Cambridge: Harvard Univ. Press, 1976), 16.

9. Albert Stone considers autobiography as an "artifact reflecting a particular vision of past, present, and future"; for, "[w] hether intended or taken as imaginative creation or historical reconstruction, an autobiography is part and parcel of cultural history." See "Modern American Autobiography: Texts and Transactions," in Fictions in Autobiography: Studies in the Art of Self-Invention, ed. John Paul Eakin (Princeton: Princeton Univ. Press, 1985), 96, 100.

10. Following this argument, the desire for personal freedom can naturally inspire larger movements toward political independence. Gordon Wood turns to Revolutionary War leadership and notes: “With the Lockean premises they had about how knowledge was acquired, everything suddenly seemed possible. The revolutionary leaders were faced with the awesome task of creating their own world." See Radicalism of the American Revolution, 191.

11. Sidonie Smith elaborates on how poststructural restructuring of time affects the canon, for it not only challenges "the notion of referentiality" but also undermines "comfortable assumptions about an informing ' $\mathrm{I} \mathrm{I}^{\prime \prime}$ For Smith, the autobiographical text ultimately becomes "a narrative artifice, privileging a presence, or identity, that does not exist outside lan- 
guage." See "The Impact of Critical Theory on the Study of Autobiography: Marginality, Gender, and Autobiographical Practice," a/b: Auto/Biography Studies 3 (1987): 5. Felicity Nussbaum considers the postmodern theoretical context "auspicious," as it provides ideas about the self as "constructs rather than eternal truths." See "Toward Conceptualizing Diary," in Studies in Autobiography, ed. James Olney, 128.

12. Robert F. Sayre marks these distinctions among the diary, journal, letter, and autobiography in terms of function and format: "[I]n an autobiography the whole life, or at least a considerable segment, is seen in long perspective; in a diary the temporal depth is shallow. The autobiographer, like the biographer and the novelist, ideally composes a complete and unified work. I say 'ideally' because he very often does not" (Examined Self 4). Paul de Man notes the "[i]mpossibility of closure and of totalization" for the autobiography. See The Rhetoric of Romanticism (New York: Columbia Univ. Press, 1984), 71.

13. Rita Felski cites the argument that a "lack of control by women over the direction of their lives, resulting from their confinement to the private sphere, is responsible for the predominance of the episodic journal structure rather than the synthesizing narrative in women's autobiographies." See Beyond Feminist Aesthetics: Feminist Literature and Social Change (Cambridge: Harvard Univ. Press, 1989), 87.

14. From yet another view, Georg Misch praises the fluid qualities of autobiographical writing as "one of the innovations brought by cultural advance, and yet it springs from the most natural source, the joy in selfcommunication and in enlisting the sympathetic understanding of others; or the need for self-assertion." Misch thus places the autobiography between romantic idealism of the self and the Gilded Age's optimism for the future. See A History of Autobiography in Antiquity, vol. 1, Berlin 1907 (Cambridge: Harvard Univ. Press, 1951), 4.

15. G. Thomas Couser offers valuable guidelines when he explains the "correspondence theory" of language in which autobiography "claims to tell some truth about a real person." Here autobiography as an "index of the self" appears to be "authoritative because it is hopelessly self-revelatory." See "Authority," a/b: Auto/Biography Studies 10 (1995): 39-40.

16. In regard to the female autobiographer, Sidonie Smith finds that she "constructs a narrative that promises both to capture the specificities of personal experience and to cast her self-interpretation in a timeless, idealized mold for posterity." See Poetics of Women's Autobiography, 45.

17. In the confession mode, the individual's life is important for what it reveals about the spiritual process and the seeker, as in Augustine's confession. Michel Foucault finds: "Confession frees, but power reduces one to silence; truth does not belong to the order of power, but shares an original affinity with freedom..." See The History of Sexuality, vol. 1, An Introduction, trans. Robert Hurley (1976; reprint, New York: Vintage 
Books, 1990), 60. From this view, as the confessional mode places the self at the center of the text itself, the individual becomes conscious that a new identity is possible, and a certain authority of self can develop.

18. In his discussion of self-examination within the Catholic doctrines of St. Bernard and St. Bonaventure, Louis L. Martz explains, "[S]elf-scrutiny forms the first degree of Truth, because it leads away from curiosity and moves toward humility". (118). The Puritan concept of election is, moreover, less fluid than the Catholic concept of confession in that for the Puritan, God's presence cannot be willed but has, instead, been predetermined. As Martz concludes his discussion, he offers the highest potential for self-examination: " $[\mathrm{T}]$ he process of self-scrutiny does not end in self-contempt, but moves beyond this to a recovery of self-esteem; self-contempt is only a half-knowledge: full self-knowledge demands a recognition of the incalculable value of the Image which lies beyond and beneath all deformity." See The Poetry of Meditation: A Study in English Religious Literature of the Seventeenth Century (New Haven: Yale Univ. Press, 1954), 152.

19. In the introduction to Esther Edwards Burr's journal, the editors, Carol F. Karlson and Laurie Crumpaker, write, "Among other mechanisms, the private diary provided Puritans with a vehicle for intense, and constant, self-appraisal." See The Journal of Esther Edwards Burr 1754-1757 (New Haven: Yale Univ. Press, 1984), 19.

20. Philippe Lejeune adds that the diary serves as the family record book, which was "centered on the heritage and the business of the family ... [and] linked more to economic and ideological activity of maintenance." See "Autobiography and Social History in the Nineteenth Century," in On Autobiography, ed. Paul John Eakin (Minneapolis: University of Minnesota Press, 1989), 168.

21. For example, in Thomas Morton's "Second Book" of New English Canaan, he claims, "The more I looked, the more I liked it." And in John Smith's Description of New England, he appeals to the self-interest of his audience with phrases such as "If a man works but three days in seven, he may get more than he can spend, unless he will be excessive."

22. In Anne Bradstreet's poem "Contemplations," for example, the spiritual and the natural worlds blend in an explanation of temporal change: "Thy presence makes it day, thy absence night, / Quarternal Seasons caused by thy might: / Hail Creature, full of sweetness, beauty, and delight" (41-43).

23. This tradition continues, as Barbara E. Lacey's remarks on the autobiography of Hannah Heaton (1721-1794): "In addition to Indians, she also made notes of fires, comets, eclipses, thunderstorms, and drought, as well as deaths from drowning, suicide, and public execution. Like the dreams, these occurrences were reminders of ever-present dangers that indicated the constant need for God's preserving care." See "The World of Hannah Heaton:The Autobiography of an Eighteenth-Century Connecticut Farm Woman," William \& Mary Quarterly 45 (1988): 287. 
24. Sewall also enjoyed a certain privilege as both a social figure and businessman. Richard Brown calls Sewall "one of Boston's richest merchants." See Knowledge Is Power: The Diffusion of Information in Early America, 1700-1865 (New York: Oxford Univ. Press, 1989), 18. Sewall also served on the Massachusetts Bay Council (1684-86) and was appointed to the Superior Court of Judicature (1692-1728).

25. Helena M. Wall also notes: "In the second half of the eighteenth century that assumption breaks down; it is replaced by a new caution about interfering in personal matters and a new regard for privacy." See Fierce Communion (Cambridge: Harvard Univ. Press, 1990), 134. Similarly, Wendy Martin speaks of Emily Dickinson's milieu: "As in most small towns, gossip was the staple of social life, and much of the conversation was concerned with narrow, moralistic judgments..." See American Triptych, 126.

26. This subjectivity is reinforced by the diary's format, which provides a semiprivate forum for its author, and as David Minter notes, "the Puritan diary characteristically focuses, as does Samuel Sewall's, on personal events treated informally." See The Interpreted Design as a Structural Principle in American Prose (New Haven:Yale Univ. Press, 1969), 70.

27. Cecelia Tichi elaborates on how the purpose of individual observation changes. For example, "Samuel Sewall had watched the darkening Northeastern sky and called the weather 'metaphoric,' since he knew it to be rich with divine meaning." Tichi then draws this comparison: "Roughly one hundred years later, imaginations like Sewall's concentrated, not on divination of cloud masses, but on planning how to manipulate and govern weather themselves." See New World, New Earth: Environmental Reform in American Literature from the Puritans through Whitman (New Haven: Yale Univ. Press, 1979), 73-74. Michael Walzer makes this additional connection between such cosmological changes and Puritan ideology: "In England, Puritanism was their effort to capture control of the changing world and their own lives-hence the insistent concern of the saints with order, method, and discipline." See Revolution of the Saints, 310.

28. Kathleen M. Swaim elaborates: "American autobiography is precisely coeval with Puritan colonization because early New England churches required candidates for membership to recite their spiritual histories before the congregations they hoped to join." See "Come and Hear," 32.

29. Along these lines, Robert Sayre defines autobiography as "an examination of the self as both a sovereign integrity and a member of society. In fact, the self is at times both these things, and autobiography is an endless stream of demonstrations of their inseparability." See Examined Self, 6.

30. Regarding the rise of autobiography in nineteenth-century France, Philippe Lejeune speculates that the urge for "autobiography appears at the point where that traditional civilization cracks," which implies that autobiography is itself a revolutionary force. See On Autobiography, 164.

31. Mikhail Bakhtin marks a similar moment in Roman history "when the 
public unity of the individual began to disintegrate [and] Taccitus, Plutarch and various rhetoricians specifically pose the question: is it permissible to write an appraisal of one's own self?" See The Dialogic Imagination (Austin: University of Texas Press, 1981), 132-33. In turn, Sidonie Smith credits the Renaissance with promoting "a new discourse and a new man" and traces this humanistic trend to the autobiography, which "promotes a conception of the human being that valorizes individual integrity and separateness and devalues personal and communal interdependency." See Poetics of Women's Autobiography, 39.

32. John Seelye finds Franklin's Autobiography a "secularization of a favorite Puritan genre, spiritual autobiography." See Prophetic Waters: The River in Early American Literature (New York: Oxford Univ. Press), 222.

33. Although Franklin clearly illustrates this process, I have decided not to focus this study extensively upon his Autobiography but to elaborate instead on lesser known works to illustrate my argument. William Breitenbach expresses a similar decision upon acknowledging the rich store of past and present Franklin scholarship. See "Religious Affections and Religious Affectations: Antinomianism and Hypocrisy in the Writings of Edwards and Franklin," in Benjamin Franklin, Jonathan Edwards, and the Representation of American Culture, ed. Barbara B. Oberg and Harry S. Stout (New York: Oxford Univ. Press, 1993), 13-26.

34. Franklin began the work in 1771, at the age of sixty-five, and left the manuscript incomplete upon his death at the age of eighty-four, in 1790.

35. Ada Van Gastel finds that Franklin's literary persona represents a sharp distinction from the historical Franklin, and she attributes Franklin's sense of control to his ability to sublimate his "instinctual forces." Basing her argument upon Freud's principle of sublimation, Van Gastel finds that Franklin's persona is "all in favor of acquiring more control over one's life; he himself is self-reliant from the moment he leaves his hometown, Boston, to the moment he embarks for England to represent the colonial interests at the end of the Autobiography." See "Franklin and Freud: Love in the Autobiography," Early American Literature 25 (1990): 170.

36 . Sidonie Smith, moreover, sees Franklin as "both the conservator of provided identities and the active agent, the self-fashioner who adjusts to new interpretive possibilities." See "Performativity, Autobiographical Practice, Resistance," a/b: Auto/Biography Studies 10 (1995): 22.

37. Virtue is of ten tested by oppressive authority figures who lack magnanimity. For example, in one of Franklin's struggles to establish a separate identity from his family, he explains how as a seventeen-year-old boy, in 1721, he sets sail from Boston to New York "near 300 miles from home" in order to escape the abuses of his brother, James. In considering such questions in relationship to the Franklin text, it may not be a simple coincidence that he is responsible for bringing Samuel Richardson's Pamela to an American audience, as this heroine's struggles against Mr. B recall 
Franklin's own struggles against authorities, such as his brother and Governor Keith. Henry Fielding's Joseph Andrews addresses these issues from a male protagonist's point of view.

38. A more significant difference between Franklin and Emerson lies in their sense of social contract. Franklin encourages individual voices to support patriotic goals that then enhance the community and nation. Emerson's call for self-reliance stands further outside of social structures; Thoreau practically abandons them.

\section{Chapter 2. Declaring the Self in the Spiritual Sphere}

1. Owen C. Watkins confirms that spiritual autobiographies were not written because the writers thought their lives were "'exemplary ones.'... They hoped through the record of their own experience to offer experimental proof of some of the eternal truths of Christianity." See The Puritan Experience: Studies in Spiritual Autobiography (New York: Schocken, 1972), 1.

2. See Daniel Shea, Spiritual Autobiography in Early America (Princeton: Princeton Univ. Press, 1988), xvii.

3. Charles Lloyd Cohen explains that conversion "begins with the soul's initial conviction of sin, an event that usually took place before an individual reached twenty-five." See God's Caress: The Psychology of Puritan Religious Experience (New York: Oxford Univ. Press, 1986), 202.

4. Patricia Caldwell notes that in the Cambridge Platform of 1648, the conversion narrative was "'personall' because it represented the speaker's own inner experience [and] 'publick' because it was required of all who would become church members in full communion ... and had to be delivered before and voted upon by an entire membership." See Puritan Conversion Narrative, 46.

5. Alfred Owen Aldridge marks differences in dates for the Great Awakening from New England to Georgia as either 1739-44 or 1734-49. See "Enlightenment and Awakening in Edwards and Franklin," in Benjamin Franklin, Jonathan Edwards, and the Representation of American Culture, ed. Barbara B. Oberg and Harry S. Stout (New York: Oxford Univ. Press, 1993), 27.

6. Susan Juster finds that evangelicals "stressed the primacy of personal, experiential religion in which the relationship of man to God was central." See "In a Different Voice': Male and Female Narratives of Religious Conversion in Post-Revolutionary America," American Quarterly 41 (1989): 37.

7. Although displays of female piety are of ten assumed to reflect a passive female subordination, Ann Taves finds that "it meant determining what response (whether active or passive) God would have the believer make to the affliction." Taves also explains the conversion experience itself as "the process whereby the 'natural' self was brought into a proper, that is, a subordinate and dependent, relationship with God," which then she marks as a "paradoxical relationship between explicit self-denial and im- 
plicit self-assertion or individualism." See "Self and God in the Early Published Memoirs of New England Women," in American Women's Autobiography: Fea(s)ts of Memory, ed. Margo Culley (Madison: Univ. of Wisconsin Press, 1992) 61, 59.

8. Cott finds that this private sphere of faith "allowed women a sort of holy selfishness, or self-absorption, the result of self-examination intrinsic to the Calvinist tradition." See The Bonds of Womanhood: "Woman's Sphere" in New England, 1780-1835 (New Haven:Yale Univ. Press, 1977), 140.

9. Amanda Porterfield's extensive discussion of Hutchinson's ordeal confirms that "Hutchinson's acceptance of the conventions of her town was the means by which she attained religious authority. She relied on the convention of female submissiveness to God to obtain social authority, and defended herself before the General Court for holding religious meetings outside of church with the argument that those meetings were designed only for women and never presumed to encroach on male authority." See Female Piety in Puritan New England: The Emergence of Religious Humanism (New York: Oxford Univ. Press, 1992), 101.

10. Although women's authority is primarily recognized through her domestic roles, Daniel Shea finds that the domestic role is not necessarily an oppressive one, especially in the case of the Ashbridge narrative, wherein he finds a "committed refusal to accept any voice as her own which she has not encountered as central to her own interiority." See the introduction to Some Account of the Fore Part of the Life of Elizabeth Ashbridge, by Elizabeth Ashbridge, in Andrews, Journeys in New Worlds, 121.

11. Certainly her male counterparts, George Fox, Jonathan Edwards, or John Woolman, struggle against potential political and religious persecution, but they are not expected to justify their absence from the domestic sphere.

12. In Mary G. Mason's discussion of Anne Bradstreet's poetry, she notes how Bradstreet integrated the domestic and the spiritual by observing "a unique harmonizing of the divine, the secular, and the personal, a unifying of a public and a private consciousness." See "The Other Voice: Autobiographies of Women Writers," in Autobiography: Essays Theoretical and Critical, ed. James Olney (Princeton: Princeton Univ. Press, 1980), 211.

13. All quotations from Ashbridge are from Some Account of the Fore Part of the Life of Elizabeth Ashbridge, ed. with introduction by Daniel B. Shea, in Andrews, Journeys in New Worlds, 117-80. Used by permission. This text is, in turn, based upon 1774 manuscript copies from the Woodbrooke Quaker Study Center, Birmingham, England, BN 1172.

14. According to David Levin, the Personal Narrative was "written within a year or two after the winter of 1739 , apparently in hope of guiding people who were trying to distinguish the signs of grace in a new outpouring of the divine spirit...." See The Puritan in the Enlightenment: Franklin and Edwards (New York: Rand McNally, 1963), 3.

15. All quotations from Edwards's Personal Narrative, and other works are 
from Jonathan Edwards: Basic Writings, ed. Ola Elizabeth Winslow (New York: Meridian, 1966), 81-96.

16. David Levin reminds us, "Edwards believes that his new insight and judgment are caused by grace, the new sense that not only sustains his conviction of God's sovereignty and justice but converts it into 'a delightful conviction." "See "Reason, Rhythm, and Style," in Oberg and Stout, Benjamin Franklin, 177-78.

17. Felicity Nussbaum notes that women's autobiographical writing "testifies to the absence of the female 'self' from theological and philosophical formulations of identity in the period.... For the Prodigal Son, it is separation from family and the fall into sin that enables him to achieve independence, as well as return to the father's fold. In contrast, the female autobiographers in their writing, subvert the idea of permanent regret or change which follows the fall." See Nussbaum, "Heteroclites: The Gender of Character in the Scandalous Memoirs," in Nussbaum and Brown, New Eighteenth Century, 157.

18. In the introduction to Esther Edwards Burr's journal, Carol F. Karlson and Laurie Crumpaker mark similar gender issues regarding conversion and observe that "for men to question their vocations in life was to question God, but for women to question theirs was to question the authority of both God and men." See Journal of Esther Edwards Burr, 10.

19. Philip Greven finds: "Evangelical family government was authoritarian and rigorously repressive. Parental authority was absolute, and exercised without check or control by anyone else within the household. Obedience and submission were the only acceptable responses for children." See The Protestant Temperament: Patterns of Child-Rearing, Religious Experience, and the Self in Early America (New York: Knopf, 1977), 32.

20. Ashbridge was married three times. She eloped, as Emory Elliott notes, when she was fourteen with "a poor stocking-weaver" ("New England Puritan" 291). This marriage lasts but a brief five months, ending upon her husband's death. Her second husband, Sullivan, whose story is included in her spiritual autobiography, dies in Cuba while protesting his part in the military. She met her third husband, Aaron Ashbridge, while in the Quaker ministry. For a more detailed biography, see Daniel Shea's Introduction, 119-41.

21. Lois J. Fowler and David H. Fowler confirm that for women as autobiographers, "the selves they put forward are inevitably shaped ... by their need to conform to-or rebel against—a society largely defined by the values of a sex that is not their own," and that "[m]en do not face that challenge." See Revelations of Self:American Women in Autobiography (Albany: SUNY Press, 1990), xxiii.

22. Virginia Brereton compares male and female narratives and finds that "women's narratives reveal more struggle, more painful self-examination, more intensity, more agonizing about 'sins' that a later age would con- 
sider harmless...." She then observes that men's conversions are "more matter-of-fact," and that "men were often reluctant even to begin the process, but once on their way they often seemed to accomplish it with less fuss." See From Sin to Salvation: Stories of Women's Conversions, 1800 to the Present (Bloomington: Indiana Univ. Press, 1991), 38.

23. Richard Slotkin points out that the captivity narratives were the "root of a growing American mythology in which self-transcendence through acculturation and acculturation through acts of violence were the basic themes." See Regeneration Through Violence, 102. The captivity narrative also serves as an inspiration for historical fiction, as in Catharine Maria Sedgwick's novel Hope Leslie, written in 1827 and set in the seventeenth century, which challenges notions of female authority in both her white and Native American female characters.

24. In addition, Helena M. Wall sees these novels as a larger eighteenth-century challenge to authority in that they "justified filial disobedience in response to parental tyranny. The political echoes were unmistakable: John Adams himself said, 'The people are Clarissa."' See Fierce Communion, 133.

25. See Jerry Frost, The Quaker Family in Colonial America: A Portrait of the Society of Friends (New York: St. Martin's Press, 1973), 25.

26. The difficulty of the female's path toward individuation is confirmed by Felicity Nussbaum when she remarks that for eighteenth-century woman, "'character' or selfhood was guaranteed only if the ' $\mathrm{I}$ ' could recreate itself in the images created by man and God." See "Heteroclites," 157.

27. That is, according to Jack D. Marietta, who qualifies this belief by explaining that although "Friends did not tolerate any form of occult divination or prophecy, they labored over the Christian interpretation of their own dreams and visions." See The Reformation of American Quakerism, 17481783 (Philadelphia: Univ. of Pennsylvania Press, 1984), 94. Daniel Shea also notes that as the dream is retold, the narration "establishes a meeting ground of the personal and impersonal" which reinforces the notion of the Quaker as a vehicle for spirit and not the author of the revelation itself. See Spiritual Autobiography, 14.

Patricia Caldwell, in turn, offers the contrast from the Puritan's perspective that "dreams are not traditionally part of the ordo salutis and that a deep suspicion of 'revelations and dreames' is firmly established in $\mathrm{Pu}$ ritan psychological theory." This is an important reminder, for it provides further contrast between the Quakers and the Puritans. See Puritan Conversion Narrative, 16.

28. Margaret Fuller comes to mind as a pioneer in gyno-centered spirituality when she proclaims, "I believe that, at present, women are the best helpers of one another. Let them think; let them act; till they know what they need." See Woman in the Nineteenth Century (1855; reprint, New York: Norton, 1971), 172.

29. In Barbara E. Lacey's discussion of Hannah Heaton's journal, Heaton's mar- 
riage to an unconverted husband poses similar problems: "[Hannah] wanted their relationship to be based on equality. She referred to 'userped authority' on an occasion when Theophilus kept her from attending a religious meeting. Further, he threw her diary into the mud, hid her spectacles so she could not spend time in pious reading, and expressed suspicions about her fidelity when she spent long hours away from home with the Separates.... She has spent a lifetime asserting her spiritual independence, yet also hoped for close companionship with her husband-goals whose irreconcilability was painful for her." See Lacey, "World of Hannah Heaton," 294-95.

30. For an extended discussion of Quaker gender relations, see David Hackett Fischer, Albion's Seed: Four British Folkways in America (New York: Oxford Univ. Press, 1989), 490-98.

31. Spiritual rebirth is thus applied equally to women and men, so that, as Jack Marietta notes, "Judeo-Christian disabilities upon women, supported by Scripture, were annulled by revelations tendered to all by the Inner Light." See Reformation of American Quakerism, 29. According to this understanding, women were not solely destined to suffering.

32. For an insightful discussion of women's devotional reading and Ashbridge's encounter with the Samuel Crisp letters, see Kevin J. Hayes, $A$ Colonial Woman's Bookshelf (Knoxville: Univ. of Tennessee Press, 1996), 45-50.

33. Phebe Davidson finds that Ashbridge's stopping here makes "good storytelling sense" and gives her a "narrative design that makes her ultimate triumph over the bad marriage the mundane balance for her spiritual salvation." See Religious Impulse in Selected Autobiographies of American Women (c. 1630-1893): Uses of the Spirit (Lewiston, N.Y.: Edwin Mellen, 1993), 60.

34. Regarding this stance, Richard Hofstadter comments: "Edwards preached with growing confidence and assertion, reinterpreting the older theology in the light of ideas taken from Locke and Newton." See America at 1750: A Social Portrait (New York: Knopf, 1971), 237.

35. David Levin comments that although Edwards is part of the evangelical movement, his Calvinism suggests a return to an earlier Puritan era, which causes him to reject "the idea of a self-determining will as absurd and selfcontradictory." See Puritan in the Enlightenment, 34. Perry Miller supports this opinion through contrast: "[Edwards] was not Thomas Jefferson: he did not preach democracy, and he had no interest whatsoever in any social revolution." See Errand into the Wilderness (Cambridge: Harvard Univ. Press, 1956), 162.

36. For Richard Slotkin this relationship "attempted to make a philosophic reconciliation between Lockean sensationalism and Calvinist orthodoxy, and his recollection of his own conversion experience emphasized the operation of the frontier landscape on his mind, couching Lockean theory 
in imagery appropriate to an American experience." See Regeneration Through Violence, 201. Bruce Kuklick reinforces that "[f]or Edwards the self is not an entity, something that stands behind appearances as their cause. Rather, the self is a construct-the structure of the series of an individual's momentary engagements with the world." See "The Two Cultures in Eighteenth-Century America," in Oberg and Stout, Benjamin Franklin, 106.

37. Daniel Shea concurs that the Narrative's "most striking characteristic is its apparent solitariness. It is not addressed to posterity in general or to Jonathan Edwards, Jr., in particular, and it is silent as to its purposes and the occasion of its composition." See Spiritual Autobiography, 182-83.

38. Karlsen and Crumpaker describe the profound influence of the revivals that Esther Edwards Burr's father led in New England: "[Esther] developed what was to be a lifelong conviction that the only true religion was indeed heartfelt, nothing short of a total and joyous submission to the will of God" (9). Hofstadter adds that for Edwards, "there could be no true religion without a profound stirring of the affections." See America at 1750, 239.

\section{Chapter 3. Declaring the Self in the Social Sphere}

1. Robert Micklus points out that Hamilton had written to his mother in April 1740 complaining of illness, and that Hamilton appears to have suffered from consumption for over fifteen years. See The Comic Genius of Dr. Alexander Hamilton (Knoxville: Univ. of Tennessee Press, 1990), 38-39.

2. All quotations from this text with their original spellings are taken from The Itinerarium of Dr. Alexander Hamilton, in Colonial American Travel Narratives, ed. Wendy Martin (New York: Penguin, 1994), 173-327.

3. All quotations from this text with their original spellings are taken from The Travel Diary of Elizabeth House Trist: Philadelphia to Natchez,178384, expertly edited and introduced by Annette Kolodny, who is responsible for recovering and preparing the original Trist manuscript for publication in Andrews, Journeys in New Worlds, 181-232. Used by permission. This text, in turn, is based upon the original 1783-84 manuscript of Trist's travel diary, which is part of the Trist-Burke Randolph Collection (MS 10, 487) from the Special Collections Department of the University of Virginia Library, Manuscripts Division. As Kolodny explains, this text is the "earliest extant diary by a white woman on the Ohio-Mississippi river frontier" (197). The first entry, however, is for December 23, 1783 , as the "first two pages of the diary are missing; the third page is badly torn along the right margin, and several lines along the bottom are missing" (201).

4. Shortly after Hamilton returned from his journey, he copied his travel diary and presented it as a gift to his friend, Onorio Razolini, who re- 
turned with it to Italy, where it remained in obscurity until the beginning of the twentieth century, when an American collector, William K. Bixby, bought the journal. Albert Bushnell Hart then transcribed and edited the original manuscript, and in 1907 Bixby published 487 copies for private distribution among friends under the elaborate title Hamilton's Itinerarium: Being a Narrative of a Journey from Annapolis, Maryland through Delaware, Pennsylvania, New York, New Jersey, Connecticut, Rhode Island, Massachusetts and New Hampshire, from May to September, 1744. In 1948, Carl Bridenbaugh edited the journal with extensive historical and biographical notes for its second, more public publication. The Itinerarium is housed at the Huntington Library in San Marino, California. See Colonial American Travel Narratives, xxxii.

5. For an excellent overview of the travel narrative, see William Spengemann, The Adventurous Muse: The Poetics of American Fiction, 1789-1900 (New Haven: Yale Univ. Press, 1977), 38-39.

6. See Micklus, Comic Genius, 78.

7. See Spengemann, Adventurous Muse, 198.

8. Brown further notes that Boston society was particularly transformed from being a "bastion of Puritanism" in 1676 to a "more open and cosmopolitan" town by 1730, where "[c]lubs and coffeehouses flourished among Boston merchants and officials who looked less and less to the sermons and lectures of the clergy for guidance, and more and more to each other and to England." See Knowledge Is Power, 16-17.

9. According to Robert Micklus, Hamilton's enthusiasm for clubs derives from his university years in Scotland, where the clubs "served to maintain a sense of national identity and social cohesion and, at the same time, to promote an awareness of the social and intellectual changes taking place at home and throughout Europe. ... Members typically met to discuss Scottish history as well as contemporary issues and developments-and, of course, to eat, drink, and simply enjoy each other's company." See Comic Genius, 24.

10. A "toaper" is a drunkard. A cup or glass filled to the brim, particularly in anticipation of drinking a toast, is called a "bumper."

11. Of "Princetown" itself, Hamilton only writes a brief paragraph and calls it "a small village," and he remarks on being "saluted with How' s't ni tap by an Indian traveller," which is the friendly Indian salutation "nehotep." See Colonial American Travel Narratives, 347.

12. In the century of migration since Plymouth Plantation, general colonial population grew from 27,950 in 1640 to $1,207,000$ in 1750 and eventually reached $5,308,483$ by 1800 .

13. In a further departure from prevailing eighteenth-century standards of natural beauty, Elizabeth McKinsey, speaking of nineteenth-century American tourism, notes that travelers who were predisposed to see nature in religious terms were drawing upon a Protestant legacy "inclined to find signs of God's power and blessing in natural features and forces." 
Thus Hamilton anticipates this "new" aesthetic. See McKinsey, "American Wanderlust," American Quarterly 43 (Dec. 1991): 682.

14. "Phizzes" means "physiognomies," as in one's face or expression.

15. For an important and thorough discussion of the Tuesday Club, see Micklus, Comic Genius. In his study of Hamilton's History of the Tuesday Club, Micklus calls this work "a comic novel. Written between the publication dates of the two great comic novels of the eighteenth centuryFielding's Tom Jones (which Hamilton read and admired) and Sterne's Tristram Shandy (which was published after Hamilton's death)-The History of the Tuesday Club in many ways resembles both" (142).

16. Brown adds that while this verbal network had been initially confined to an elite circle privy to news sources, the expansion of American newspapers, taverns, and clubs played a "more significant role in facilitating the diversity that was growing within the elite and beyond it." See Knowledge Is Power, 41.

17. King Philip was the Wampanoag leader, Metacomet, who was shot in 1676 by an Indian ally of the colonists.

18. As a footnote to his inquisitive search, on May 28, 1747, two and a half years after his return, "Hamilton married Margaret Dulany, daughter of Daniel Dulany the Elder, and thus became a member of one of the richest and most powerful Maryland families." See J. A. Leo Lemay, Men of Letters in Colonial Maryland (Knoxville: Univ. of Tennessee Press, 1972), 232.

19. There is a hint of this unlikely convergence in her own beginnings. Her parents, Samuel and Mary House, had been "disowned" by their Quaker community in Philadelphia on August 25, 1751, for "marrying contrary to discipline." Their act does suggest that the Houses themselves were of independent minds. Elizabeth House, their first child, was born in Philadelphia sometime between this decisive meeting and the end of 1751 . See William Wade Hinshaw, Encyclopedia of American Quaker Genealogy (Ann Arbor: Edwards Brothers, 1938), 2:555. The marriage ceremony itself may have been performed in a non-Quaker church. The minutes of the Friends Meeting for Philadelphia on this date tell us that Samuel and Mary "neglected meetings of worship" and showed "no signs of repenting." There is no indication of any objection on their part; no appeals were filed. Why Samuel House, a descendent of a Samuel House who emigrated from Eastwell, Kent, England to Scituate, Massachusetts, in 1634, would deliberately choose to sever his formal connections with the Quakers is unclear. Similarly, Mary House's reasons are unknown.

20. Jefferson reinforces this longstanding relationship in several letters to Madison. One example is on January 31, 1783, when Jefferson closes his letter to Madison from Baltimore with this reference: "Be pleased to present me very affectionately to the ladies and gentlemen whose pleasing society I lately had at Mrs. House's" (Boyd 6:226). On August 31, 1783, Jefferson writes from Monticello to Madison: "Be so good as to present 
my compliments to Mrs. House and Mrs. Trist and to ask whether the pleasure of lodging in their house may be counted among the circumstances which will render Philadelphia agreeable to me in case of the return of Congress thither" (Boyd 6:336). Quotations from Jefferson's correspondence, unless otherwise noted, are taken from Thomas Jefferson, The Papers of Thomas Jefferson, ed. Julian P. Boyd, et al. 26 vols. to date (Princeton: Princeton Univ. Press, 1950-).

21. Robert U. Drexler explains that "[Nicholas Trist] had been a British officer from Devon who was stationed in Philadelphia at the time of the American Revolution. Later, Jefferson was among those who encouraged him to remain in the United States and he became a naturalized American citizen with Jefferson's assistance." See Guilty of Making Peace: A Biography of Nicholas P. Trist (Lanham, Md.: Univ. Press of America, 1991), 16.

22. Trist's biography is explained in greater detail in Kolodny's introduction, 183-85.

23. Significantly, Philadelphia, founded in 1682, has become a point of comparison in its relatively short history, which speaks of the growth of American cities. It is also at this time the second largest city after Boston and ahead of New York.

24. Annette Kolodny notes that "Trist was to travel often throughout the rest of her life-though nothing would match the adventure or the perils of her journey to Natchez in 1783-84." See "Introduction," in Journeys in New Worlds, 196.

25. This desire to transform the frontier, moreover, evokes Annette Kolodny's examination of a woman's perspective of the frontier, and her desire for "locating a home and a familial human community within a cultivated garden. ... In the women's fantasies, at least, the garden implied home and community, not privatized erotic mastery." See The Land Before Her: Fantasy and Experience of the American Frontiers, 1630-1860 (Chapel Hill: Univ. Press North Carolina Press, 1984), xiii.

26. As Trist's descriptions envision a more "civilized" landscape, they also anticipate Frederick Jackson Turner's 1893 treatise, "The Significance of the Frontier in American History," in which he describes the frontier as "the outer edge of the wave-the meeting point between savagery and civilization" and discusses the importance of "free lands" to the American individual consciousness. Yet for both Trist and Turner, the land can only be conceived in terms of freedom by assuming that the land itself can be purchased and, therefore, owned. This primary assumption clashes with a fundamental view of Native Americans that as land cannot indeed be owned, it cannot be considered free. Instead, Trist promotes a belief in the individual's right to alter his or her world regardless of indigenous people's rights.

27. Their shared experienced is confirmed by Thomas Jefferson, who writes on June 24, 1798, from Philadelphia to a Mr. Philip Nolan about the state 
of the wild horse in America. He has heard that there are "large herds of horses in a wild state, in the country west of the Mississippi," and he fears that their freedom will soon be diminished. He goes on to note that "the condition of America is rapidly advancing to the same." Having drawn the parallel, Jefferson requests Mr. Nolan's assistance and adds: "You will render to natural history, a very acceptable service, therefore, if you will enable our Philosophical society to add so interesting a chapter to the history of this animal." Writings, ed. Merrill D. Peterson (New York: Library of America, 1984), 1051. As a naturalist in a period of rapid expansion, Jefferson expresses concern over the vanishing frontier and the specific threat to the wild horse's future. Although Jefferson practically concedes the pending disappearance of this animal, he has the foresight to solicit some observations and data. Prior to both Lewis and Clark and the Louisiana Purchase, Jefferson's letter raises concerns for the pending environmental impact that westward expansion will create.

28. While that letter has, unfortunately, never been recovered, Trist refers to it in a letter to Jefferson from Pittsburgh written en route on April 8, 1784: "I had the pleasing satisfaction to receive a letter of yours dated 22nd of Dec. which was the day after I set out on my journey. Had I received it in time I do not think it wou'd have prevented my undertaking the journey tho no ones advise wou'd have had greater weight ..." (Boyd 7:86).

29. According to The Papers of Thomas Jefferson and the Special Collections of the Alderman Library at the University Press Virginia, there are approximately twenty-two letters written between Trist and Jefferson; five of these letters are indicated in Jefferson's records but have not been found. Of the surviving letters, Jefferson wrote nine and Trist wrote eight. There are fourteen other letters that concern Trist-Jefferson relations and include letters to or from John Madison, Martha (Patsy) Jefferson, John Trumbull, and others.

30. Trist and Jefferson frequently consult each other about their children. On November 28, 1783, less than a month before Trist leaves for her journey, Jefferson writes to Patsy from Annapolis with this advice: "As long as Mrs. Trist remains in Philadelphia cultivate her affections. She has been a valuable friend to you and her good sense and good heart make her valued by all who know her and by nobody on earth more than by me" (Boyd 6:360). When Nicholas Trist dies, they consult each other as single parents, for neither Trist nor Jefferson remarry. So that when Jefferson is in France, Trist asks for his assistance in securing an inheritance for her son, Browse, whose British relatives have not been forthcoming with his fair share of his father's estate. Jefferson became quite involved in helping Trist establish Browse's line of inheritance.

In his letter to a Mrs. Champernoune on February 23, 1787, Jefferson conveys all that he knows of Browse's situation and praises Elizabeth Trist as "a most excellent mother, judicious and prudent, and devoting her whole 
existence to the care of her son.... [B]ut as he makes further progress these expences will increase, and she is not rich. I fear the possibility therefore that his education may suffer. He is a beautiful boy, of mild dispositions, and fine genius, and as far as can be judged at his age, we may rely that he will do honour to his family, be the station, to which he may be called in that, ever so honorable" (Boyd 11:178).

31. Margo Culley notes, "It is only relatively recently (roughly in the last one hundred years) that the content of the diary has been a record of private thoughts and feelings to be kept hidden from other's eyes"; instead, "diaries were semi-public documents intended to be read by an audience." See "'I Look at Me': Self as Subject in the Diaries of American Women," Women's Studies Quarterly 3-4 (1989): 15.

32. In Trist's December 25, 1784, letter to Jefferson, she refers to a previous letter from Jefferson about his wife's death:

Often do I think of a passage you wrote as a postscript in Patsys letter wherein you compared my then situation to heaven in comparison to those who was cut off from all hope of ever seeing the object of their affections. I was at that time sensible of justness of your observation and forgot my own troubles in commiserating the pang your heart must have felt when you suggested that thought to me by way of consolation. I did sincerely Sympathize with you and since I have experienced the like calamity I have thought of your sufferings when I was allmost sinking under my own. (Boyd 7:583)

33. Trist will sometimes dismiss her physical surroundings as inadequate when they lack the presence of her friends and loved ones. Trist writes to Jefferson on April 8,1784, that "the suffering of the Body is a great relief to the mind" and concludes on this apprehensive note: "This will be the last time I shall trouble you with a perusal of my scrall while in this part of the World. If I escape with life you shall hear from me by another route" (Boyd 7:87). Despite her misgivings, Trist writes two weeks later thanking Jefferson for "his kind favor by Capt. Lynn," a reference that has yet to be linked to its source.

34. Letter delays also affect the way that information is shared and, in some cases, withheld. For instance, while Elizabeth Trist continues on her southward journey anticipating a joyful reunion, her friends and relatives back in Philadelphia have already discovered the unfortunate truth about her husband's death. On May 25, 1784, Jefferson writes to Madison and marks the tragedy of this lapse: "Poor Mrs. Trist is in a situation which gives us much pain. Her husband is dead, and she without knowing it is proceeding down the Ohio and Mississippi in hopes of joining him. There is a possibility only that letters sent from hence may overtake her at the Falls of Ohio and recall her to this place" (Boyd 8:136). 
35. In James Fenimore Cooper's The Prairie, for example, the Trapper is the self-effacing frontiersman with an impassioned connection to the land, its resources, and its native peoples.

36. Richard Slotkin identifies the development of fictional history as a "gradually increasing tendency to substitute imagination for experience, to offer a fictionalized, sensationalized account as a true narrative." See Regeneration Through Violence, 224.

\section{Chapter 4. Declaring the Self in the Political Sphere}

1. Jay Fliegelman notes that by the middle of the eighteenth century, public speaking, in turn, became "an occasion for the public revelation of a private self. Such a private self would then be judged by private rather than public virtues: prudence, temperance, self-control, honesty, and most problematically, sincerity." See Declaring Independence: Jefferson, Natural Language, E the Culture of Performance (Stanford: Stanford Univ. Press, 1993), 24.

2. All quotations from the Autobiography are from Jefferson, Writings, 3101. Used by permission. The source of this text is Paul Leicester Ford's edition, 1892-99.

3. That is, "either plaintiff of defendant." See The Life and Writings of Thomas Jefferson, ed.Adrienne Koch and William Peden (New York: Random, 1944), 3.

4. Merrill D. Peterson observes that despite the "vast corpus of papers, private and public, his personality remains elusive... Jefferson is perhaps the least self-revealing and the hardest to sound the depths of being. It is a mortifying confession but he remains for me, finally, an impenetrable man." See Thomas Jefferson and the New Nation: A Biography (New York: Oxford Univ. Press, 1970), viii.

Dumas Malone views Jefferson in this manner: "It has seemed to me that the only way to catch the real likeness of the man is to watch his picture grow until it assumes its essential outline, and then to watch it change, as time and circumstance employ a fine pencil. He loses none of his fascination but he does lose much of his elusiveness when one follows him through life the way he himself went through it, that is, chronologically." See Jefferson the Virginian (Boston: Little Brown, 1948), xi.

5. See Douglas L. Wilson, "Thomas Jefferson and the Character Issue," Atlantic Monthly, Nov. 1992, 65.

6. Barry Shain reminds us that in contrast to our understanding of "individual autonomy," to the eighteenth-century mind it "would have been seen as a form of sinful degeneration." See Myth of American Individualism, 50. As a further reminder to place our understanding of individualism, Fliegelman finds that " $[\mathrm{w}]$ hat most post-Freudian readers cannot 
accept. ... is that Jefferson's self-presentation is not merely a strategy of concealment. Rather, it represents a particular moral and social conception of identity." See Declaring Independence, 122.

7. For further discussion on the composition of Adams's narrative, see Elizabeth M. Renker, "'Declaration-Men' and the Rhetoric of Self-Presentation," Early American Literature 24 (1989): 132n.

8. All quotations from the Autobiography are from The Adams Papers, Series I:Diaries; Diary and Autobiography of John Adams, ed. L. H. Butterfield. By the President and Fellows of Harvard College (Cambridge: Harvard Univ. Press, 1961). Reprinted by permission of Harvard Univ. Press.

9. Gordon Wood comments on the shared fascination of the founding fathers "with the power of lineage," and notes that "[t]o his dying day John Adams was haunted by the veneration for family that existed in New England. Jefferson, too, always felt the power of genealogy." See Radicalism of the American Revolution, 182.

10. John Ferling writes that Adams "often displayed unattractive qualities, including calculation, excessive ambition, rage, jealousy, and vanity." See John Adams: A Life (Knoxville: Univ. of Tennessee Press, 1992), 4. Peter Shaw makes this comment about Adams's ambition: "Still, much as he sought the universal admiration that he felt he deserved, he never could put himself out to be popular. The truth was that from the beginning he courted not popularity but unpopularity as a mark of distinction. Outside of his own family there were only a few men whose approbation he could bear." See The Character of John Adams (Chapel Hill: Univ. of North Carolina Press, 1976), 15.

11. See Greven, Protestant Temperament.

12. It was a lingering concern, for three decades after the American Revolution, Jefferson writes to Elizabeth House Trist on June 10, 1814, that "tyranny prevails," after he hears news that "Bonaparte has the two emperors and two kings in his possession, and consequently the whole continent of Europe at his nod... . such then is our present crises, that we know not what to hope or fear, and only standing to our helm, must abide, with folded arms, the abuse of the storm." See Thomas Jefferson, Poplar Forest, to Elizabeth House Trist, 10 June 1814, ALS [Microfilm], \#5213-d in Special Collections, Univ. of Virginia Library, Charlottesville, Virginia.

13. In Gordon Wood's evaluation, the form of government called republicanism "put an enormous burden on individuals. They were expected to suppress their private wants and interests and develop disinterestedness-the term the eighteenth century most of ten used as a synonym for civic virtue: it better conveyed the increasing threats from interest that virtue now faced." See Radicalism of the American Revolution, 104-5.

14. Shain finds that "[p] ublic and private needs were of ten seen as potentially competitive demands, with a definite hierarchy of value that placed cor- 
porate needs ahead of subjective individual ones." See Myth of American Individualism, 28.

15. A revolutionary statesman.

16. Elizabeth M. Renker also discusses Adams's competitive feelings about this authorship. See "'Declaration-Men,"' 120-34.

17. That is, "on an equal basis."

18. Robert Ferguson encourages "studying the writings of the Founding Fathers as literature," for as "men of letters. No generation has looked more carefully to the written word for identity." See "We Hold These Truths': Strategies of Control in the Literature of the Founders," Reconstructing American Literary History, ed. Sacvan Bercovitch (Cambridge: Harvard Univ. Press, 1986), 1-2.

19. See Robert A. Ferguson, "The American Enlightenment," in The Cambridge History of American Literature 1:365.

20. According to Henry Steele Commager, Jefferson embraces scientific ideas with "his inexhaustible ingenuity, his sleepless curiosity, his countless experiments, his boldness and vision, his instinct for the practical and the useful, and for the beautiful too." See The Empire of Reason: How Europe Imagined and America Realized the Enlightenment (Garden City: Doubleday, 1977), 105.

21. In terms of Jefferson's milieu, Jay Fliegelman finds that there was "the belief that in an ideal world all relationships would be contractual. In such a relationship all obligations and expectations are made explicit before the voluntary consent of the relevant parties." See Prodigals and Pilgrims: The American Revolution against Patriarchal Authority (New York: Cambridge Univ. Press, 1982), 123.

22. Garry Wills thus explains that for Jefferson, the notion of "revolution" was still associated with the notion of heavenly change, a natural occurrence, and that " $\mathrm{r}$ ] evolution was such a respectable term in eighteenth-century English that Edmund Burke tried to save it from French capture. ... revolution becoming the more drastic word for rejection of authority." See Inventing America: Jefferson's Declaration of Independence (New York: Doubleday, 1978), 52.

23. To clarify the difference between landed families in England and America, Gordon Wood states that "four hundred great families owned a fifth of all the land in England. By contrast, most American farmers owned their own land ... the radical importance of this landownership in an Englishspeaking world dominated by rent-paying tenants and leaseholders cannot be exaggerated: even before the Revolution it gave Americans a sense of their egalitarian exceptionalism." See Radicalism of the American Revolution, 123.

24. Henry Steele Commager finds that Jefferson "took the lead in abolishing those remnants of feudalism - primogeniture and entail—and his program 
of Disestablishment carried with it the ultimate forfeiture of the glebe lands of the Church. His proposal to grant fifty acres to every adult male who was landless was rejected." See Jefferson, 55.

25. Henry F. May reinforces this association that the "American Revolution was seen in Paris mainly in terms drawn from Rousseau. The virtuous Americans, free from prejudice and close to nature, had swept away the past and opened a new path for the whole world." See The Enlightenment in America (New York: Oxford, 1976), 167.

26. There were periods of estrangement, however, between 1796 and 1801 and between 1801 and 1812. See The Adams-Jefferson Letters: The Complete Correspondence Between Thomas Jefferson and Abigail and John Adams, ed. Lester J. Cappon, 2 vols. (Chapel Hill: University of North Carolina Press, 1959), 1:239-44 and 2:283-89.

27. Copying his letters was also not an easy task; Jefferson maintained an immense correspondence estimated to have been between fifty and seventy-five thousand letters. See The Life and Writing of Thomas Jefferson, ed. Adrienne Koch and William Peden (New York: Random, 1944), 350. Jefferson wrote approximately eighteen thousand of these letters himself; see Fawn M. Brodie, Thomas Jefferson: An Intimate History (New York: Norton, 1974), 22.

28. Cathy Davidson finds that Adams was "conscious of the distance between his own public words and his private sentiments"; therefore, this misrepresentation might have been even more alarming to him for its capacity to confuse and misrepresent. Davidson also suggests that the passage of the Alien and Sedition Acts during the Adams administration "may very well have arisen partly because those in power did not know how to interpret the rhetoric they read in the newspapers and did not understand the new rules of the inflammatory vernacular discourse that suddenly seemed ubiquitous in the nation." See Revolution and the Word: The Rise of the Novel in America (New York: Oxford Univ. Press, 1986), 160.

29. Dr. Arthur Lee was appointed to negotiate a treaty of alliance with France in 1776 and to solicit aid for the Revolution.

30. Quotations from Jefferson's correspondence, unless otherwise noted, are taken from Thomas Jefferson, Papers of Thomas Jefferson.

31. Adams may have taken Franklin's theories seriously, as three years later, on December 27,1779, while stopping for the night in a tavern in rural Spain, Adams complains in his Diary of the "unwholesome Air of the Chamber" and his "Inclination and Advice was to keep the Ports open, choosing to encounter the worst Air from abroad rather than be suffocated or poisoned with the Smoke and contaminated Air within" (4:215).

32. Wall elaborates on Locke's profound influence on family structures, noting that "Lockean ideas promoted a special place for children and childrearing within the family and gave the relationship between parents 
and children unique importance. ... One effect of Lockean ideas on parent-child relations was to undermine the patriarchal authority within the family. Other factors contributed to this erosion, including economic changes." See Fierce Communion, 131.

33. Fliegelman elaborates on this mirrored relationship between the political and family structures in the New Republic: "The problems of family government addressed in the fiction and pedagogy of the period-of balancing authority with liberty, of maintaining a social order while encouraging individual growth-were the larger political problems of the age translated into the terms of daily life." See Prodigals and Pilgrims, 5. Robert Weisbuch also marks this particularly American impulse as "a nationalism made larger and more personal than a European ever would experience it." See Atlantic Double-Cross: American Literature and British Influence in the Age of Emerson (Chicago: Univ. of Chicago Press, 1986), xvii.

34. In a letter to the Marquis de Chastellux, on November 26, 1782, from Ampthill, Jefferson writes of Martha Jefferson's death: "A single event wiped away all my plans and left me a blank which I had not the spirits to fill up." See Writings, 780.

35. Reprinted from The Family Letters of Thomas Jefferson, ed. Edwin M. Betts and James A. Bear Jr. (Columbia: University of Missouri Press, 1966), 19. Used by permission of the University of Missouri Press, by the Curators of the University of Missouri.

36. Jefferson again writes to Trist, from Monticello on February 1, 1814, to convey his daughter's difficulty in childbirth: "[O]ur Martha has had a poor time since the birth of her new daughter harrassed with lingering fevers which have greatly debilitated her. She ought to have come out today, but is not strong enough, and it is snowing." Jefferson then continues with a general report of his family's health and tells Trist that his grandchildren and great grandchildren are "seranading us in every corner of the house with the whooping cough. Most of them however have it favorably, some badly, but none dangerously. I have heard only of two deaths from it in the neighborhood" (Special Collections, Univ. of Virginia Library, Charlottesville, Virginia, \#5213-d).

37. See Correspondence between the Hon. John Adams and the Late William Cunningham, Esq. (Boston, 1823), 19.

38. Susan Stanford Friedman reminds us of an inherent difficulty for the female autobiographer to project "individualistic models of the self" (35). Freidman adds that for women, "writing the self shatters the cultural hall of mirrors and breaks the silence imposed by male speech" (41). See "Women's Autobiographical Selves: Theory and Practice," The Private Self, ed. Shari Benstock (Chapel Hill: Univ. of North Carolina Press, 1988).

39. Although there is no evidence that Trist knew of this flirtation, Jefferson makes it clear that he is suffering as he continues in this letter: "I am 
burning the candle of life without present pleasure, or future object. A dozen or twenty years ago this scene would have amused me. But I am past the age for changing habits.... I take all the fault on myself, as it is impossible to be among a people who wish more to make one happy. ... Laid up in port, for life, as I thought myself at one time, I am thrown out to sea, and an unknown one to me. By so slender a thread do all our plans of life hang!" (Boyd 10:600). This is a depressing sentiment indeed, considering that Jefferson was only forty-three when he wrote this letter, and it was still fifteen years before he was to become president.

40. It must be remembered that the quality of randomness permeates Tristram Shandy, one of Jefferson's favorite books. 


\section{Bibliography}

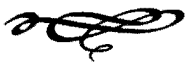

\section{Primary Sources}

Adams, Abigail. New Letters of Abigail Adams, 1788-1801. Ed. Stewart Mitchell. Boston: Houghton Mifflin, 1947.

Adams, Abigail, andJohn Adams. The Adams Papers, Series II: Correspondence:Adams Family Correspondence. Ed. L. H. Butterfield. 4 vols. Cambridge: Harvard Univ. Press, 1963. The Book of Abigail and John: Selected Letters of the Adams Family 1762-1784. Ed. L. H. Butterfield. Cambridge: Harvard Univ. Press, 1975.

- Familiar Letters of John Adams and His Wife Abigail Adams, During the Revolution. Ed. Charles Francis Adams. New York: Hurd and Houghton, 1876.

Adams, John. The Adams Papers, Series I: Diaries; Diary and Autobiography of John Adams. Ed. L. H. Butterfield. 4 vols. Cambridge: Harvard Univ. Press, 1961.

- The Adams Papers, Series III: General Correspondence and Other Papers of the Adams Statesmen: Papers of John Adams. Ed. Robert J. Taylor. 4 vols. Cambridge: Harvard Univ. Press, 1977-.

Adams, John, and Thomas Jefferson. The Adams-Jefferson Letters: The Complete Correspondence Between Thomas Jefferson and Abigail and John Adams. Ed. Lester J. Cappon. 2 vols. Published for the Institute of Early American History and Culture. Chapel Hill: Univ. of North Carolina Press, 1959.

Andrews, William L., ed. Journeys in New Worlds: Early American Women's Narratives. Madison: Univ. of Wisconsin Press, 1990.

Ashbridge, Elizabeth. Some Account of the Fore Part of the Life of Elizabeth Ashbridge. 1774. Ed. Daniel B. Shea. In Journeys in New Worlds: Early American Women's Narratives, ed. William L. Andrews, 147-80.

Boyd, Julian P., et al., eds. The Papers of Thomas Jefferson. 26 vols. to date. Princeton: Princeton Univ. Press, 1950-.

Bradford, William. Bradford's History "Of Plimoth Plantation." Boston: Wright \& Potter Printing, 1898.

Edwards, Jonathan. Jonathan Edwards: Basic Writings. Ed. Ola Elizabeth Winslow. New York: Meridian, 1966.

Franklin, Benjamin. The Autobiography. Ed. J. A. Leo Lemay and Paul M. Zall. New York: Norton, 1986. 
Franklin, Benjamin, and Jonathan Edwards. Benjamin Franklin and Jonathan Edwards: Selections from Their Writings. Ed. Carl Van Doren. New York: Scribner's, 1920.

Hamilton, Alexander, Dr. Gentleman's Progress:The Itinerarium of Dr. Alexander Hamilton, 1744. Ed. Carl Bridenbaugh. Chapel Hill: Univ. of North Carolina Press, 1948.

- Hamilton's Itinerarium: Being a Narrative of a Journey from Annapolis, Maryland through Delaware, Pennsylvania, New York, New Jersey, Connecticut, Rhode Island, Massachusetts and New Hampshire, from May to September, 1744. Ed. Albert Bushnell Hart. St. Louis: William K. Bixby, 1907. Reprint, New York: Arno Press, 1971. - The Itinerarium of Dr. Alexander Hamilton. In Colonial American Travel Narratives. Edited and with an introduction by Wendy Martin. Explanatory Notes by Susan Imbarrato and Deborah Dietrich, 173-327. New York: Penguin, 1994.

Hart, Albert Bushnell, ed. Introduction to Hamilton's Itinerarium, by Alexander Hamilton. Jefferson, Thomas. The Family Letters of Thomas Jefferson. Ed. Edwin M. Betts and James

A. Bear Jr. Columbia: Univ. of Missouri Press, 1966.

-The Life and Writings of Thomas Jefferson. Ed. Adrienne Koch and William Peden. New York: Random, 1944.

- The Papers of Thomas Jefferson. Ed. Julian P. Boyd, et al. 26 vols. to date. Princeton: Princeton Univ. Press, 1950-.

-Writings. Ed. Merrill D. Peterson. New York: Library of America, 1984.

. Monticello. Letter to Elizabeth House Trist. 9 Apr. 1797. ALS [Microfilm]. \#5213-d in Special Collections. Univ. of Virginia Library, Charlottesville, Virginia. - Washington. Letter to Elizabeth House Trist. 22 Dec. 1807. ALS [Microfilm]. \#5213-d in Special Collections. Univ. of Virginia Library, Charlottesville, Virginia.

- Monticello. Letter to Elizabeth House Trist. 1 Feb. 1814. ALS [Microfilm]. 5213-d in Special Collections. Univ. of Virginia Library, Charlottesville, Virginia. - Poplar Forest. Letter to Elizabeth House Trist. 10 June 1814. ALS [Microfilm]. \#5213-d in Special Collections. Univ. of Virginia Library, Charlottesville, Virginia.

Sewall, Samuel. The Diary of Samuel Sewall: 1674-1729. Ed. M. Halsey Thomas. 2 vols. New York: Farrar, Straus and Giroux, 1973.

Trist, Elizabeth. The Travel Diary of Elizabeth House Trist: Philadelphia to Natchez, 178384. Ed. Annette Kolodny. In Journeys in New Worlds: Early American Women's Narratives, ed. William L. Andrews, 201-32.

—. Acadian Coast. Letter to Thomas Jefferson. 12 Mar. 1785. ALS [Photostat]. \#10487 in Special Collections. Univ. of Virginia Library, Charlottesville, Virginia.

Winthrop, John. Winthrop Papers. Vol. 2, 1623-1630. Boston: Massachusetts Historical Society, 1931.

\section{Secondary Sources}

Adams, Percy G. Travel Literature and the Evolution of the Novel. Lexington: Univ. Press of Kentucky, 1983.

Adams, Timothy Dow. Telling Lies in Modern American Autobiography. Chapel Hill: Univ. of North Carolina Press, 1990.

Aldridge, Alfred Owen. "Enlightenment and Awakening in Edwards and Franklin." In 
Benjamin Franklin, Jonathan Edwards, and the Representation of American Culture, ed. Barbara B. Oberg and Harry S. Stout, 27-41.

. "Form and Substance in Franklin's Autobiography." In Essays on American Literature in Honor of Jay B. Hubbell, ed. Clarence Gohdes, 47-62. Durham, N.C.: Duke Univ. Press, 1967.

Anderson, Virginia DeJohn. New England's Generation: The Great Migration and the Formation of Society and Culture in the Seventeenth Century. Cambridge: Cambridge, Univ. Press, 1991.

Bacon, Margaret Hope. Mothers of Feminism: The Story of Quaker Women in America.

New York: Harper, 1986.

- The Quiet Rebels: The Story of the Quakers in America. New York: Basic, 1969.

Bailyn, Bernard. The Ideological Origins of the American Revolution. Cambridge: Harvard Univ. Press, 1967.

Bakhtin, Mikhail M.The Dialogic Imagination: Four Essays. Ed. Michael Holquist. Trans.

Caryl Emerson and Michael Holquist. Austin: Univ. of Texas Press, 1981.

Banes, Ruth A. "The Exemplary Self: Autobiography in Eighteenth Century America." Biography 5 (1982): 226-39.

Beidler, Philip D. “The 'Author' of Franklin's Autobiography." Early American Literature 16 (1981/2): 257-69.

Bell, Betty Louise. "Almost the Whole Truth: Gerald Vizenor's Shadow-Working and

Native American Autobiography." a/b: Auto/Biography Studies 7 (Fall 1992): 18095.

Benjamin, Philip. The Philadelphia Quakers in the Industrial Age, 1865-1920. Philadelphia: Temple Univ. Press, 1976.

Benstock, Shari. "Authorizing the Autobiographical." In The Private Self: Theory and Practice of Women's Autobiographical Writings, ed. Shari Benstock, 10-33.

- - ed. The Private Self: Theory and Practice of Women's Autobiographical Writings. Chapel Hill: Univ. of North Carolina Press, 1988.

Bercovitch, Sacvan. The American Jeremiad. Madison: Univ. of Wisconsin Press, 1978.

- The Puritan Origins of the American Self. New Haven: Yale Univ. Press, 1975.

, ed. The American Puritan Imagination: Essays in Revaluation. Cambridge: Cambridge Univ. Press, 1974.

- ed. The Cambridge History of American Literature. Vol. 1, 1590-1820. New York: Cambridge Univ. Press, 1994.

- ed. Reconstructing American Literary History. Cambridge: Harvard Univ. Press, 1986.

Bercovitch, Sacvan, and Myra Jehlen, eds. Ideology and Classic American Literature. New York: Cambridge Univ. Press, 1986.

Bogel, Fredric. "Johnson and the Role of Authority." In The New Eighteenth Century: Theory, Politics, English Literature, ed. Felicity Nussbaum and Laura Brown, 189-209. Boorstin, Daniel I. The Americans: The Colonial Experience. New York: Random, 1958. -The Americans: The National Experience. New York: Random, 1965.

Brailsford, Mabel Richmond. Quaker Women: 1650-1690. London: Duckworth, 1915. Breitenbach, William. "Religious Affections and Religious Affectations: Antinomianism 
and Hypocrisy in the Writings of Edwards and Franklin." In Benjamin Franklin, Jonathan Edwards, and the Representation of American Culture, ed. Barbara B. Oberg and Harry S. Stout, 13-26.

Brereton, Virginia Lieson. From Sin to Salvation: Stories of Women's Conversions, 1800 to the Present. Bloomington: Indiana Univ. Press, 1991.

Brodie, Fawn M. Thomas Jefferson: An Intimate History. New York: Norton, 1974.

Brodszki, Bella, and Celeste Schenk, eds. Life/Lines: Theorizing Women's Autobiography. Ithaca: Cornell Univ. Press, 1988.

Brown, Elizabeth Potts, and Susan Mosher Stuard, eds. Witnesses for Change: Quaker Women over Three Centuries. New Brunswick: Rutgers Univ. Press, 1989.

Brown, Richard D. Knowledge Is Power: The Diffusion of Information in Early America, 1700-1865. New York: Oxford Univ. Press, 1989.

Bruss, Elizabeth W. Autobiographical Acts: The Changing Situation of a Literary Genre. Baltimore: Johns Hopkins Univ. Press, 1976.

Buell, Lawrence. New England Literary Culture From Revolution Through Renaissance. New York: Cambridge Univ. Press, 1986.

- "Transcendental Self-Examination and Autobiographical Tradition." In Literary Transcendentalism: Style and Vision in the American Renaissance. 263-83. Ithaca: Cornell Univ. Press, 1973.

Burke, Edmund. A Philosophical Inquiry into the Origin of Our Ideas of the Sublime and Beautiful. 1757. London: privately printed, 1812. Reprint, Charlottesville, Va.: Ibis Publishing, n.d.

Burr, Anna Robeson. The Autobiography: A Critical \& Comparative Study. New York: Houghton, 1909.

Burstein, Andrew. The Inner Jefferson: Portrait of a Grieving Optimist. Charlottesville: Univ. of Virginia Press, 1995.

Butterfield, L. H., ed. Introduction to The Adams Papers, Series I: Diaries, by John Adams.

- Introduction to the Book of Abigail and John, by John and Abigail Adams.

Caldwell, Patricia. The Puritan Conversion Narrative: The Beginnings of American Expression. Cambridge: Cambridge Univ. Press, 1983.

Canny, Nicholas, and Anthony Pagden, eds. Colonial Identity in the Atlantic World, 15001800. Princeton: Princeton Univ. Press, 1987.

Chase, Richard. The American Novel and Its Tradition. Garden City, N.Y.:Doubleday, 1957.

Clark, Harry Hayden, ed. Transitions in American Literary History. New York: Octagon, 1975.

Cohen, Charles Lloyd. God's Caress: The Psychology of Puritan Religious Experience. New York: Oxford Univ. Press, 1986.

Commager, Henry Steele. The Empire of Reason: How Europe Imagined and America Realized the Enlightenment. Garden City, N.Y.: Doubleday, 1977.

- Jefferson, Nationalism, and the Enlightenment. New York: George Braziller, 1975.

Cooley, Thomas. Educated Lives: The Rise of Modern Autobiography in America. Columbus: Ohio State Univ. Press, 1976.

Cott, Nancy F. The Bonds of Womanhood: "Woman's Sphere" in New England, 1780-1835. New Haven: Yale Univ. Press, 1977. 
Couser, G. Thomas. Altered Egos: Authority in American Autobiography. New York: Oxford Univ. Press, 1989.

- American Autobiography:The Prophetic Mode. Amherst: Univ. of Massachusetts Press, 1979.

—. "Authority." a/b: Auto/Biography Studies 10 (1995): 34-49.

Cox, James Melville. "Autobiography and America." Virginia Quarterly Review 47 (1971): 252-77.

- Recovering Literature's Lost Ground: Essays in American Autobiography. Baton Rouge: Louisiana State Univ. Press, 1989.

Cox, Stephen D. "The Stranger Within Thee": Concepts of the Self in Late-EighteenthCentury Literature. Pittsburgh: Pittsburgh Univ. Press, 1980.

Crevecoeur, J. Hector St. John de. Letters from an American Farmer. 1782. In Letters from an American Farmer and Sketches of Eighteenth-Century America, edited and with an introduction by Albert Stone. New York: Penguin, 1981.

Culley, Margo. "I Look at Me': Self as Subject in the Diaries of American Women." Women's Studies Quarterly 3-4 (1989): 15-22.

- "What a Piece of Work is 'Woman'! An Introduction." In American Women's Autobiography: Fea(s)ts of Memory, edited and with an introduction by Margo Culley, 3-31.

, ed. A Day at a Time: The Diary Literature of American Women from 1764 to the Present. New York: Feminist, 1985.

- ed. American Women's Autobiography: Fea(s)ts of Memory. With an introduction by Margo Culley. Madison: Univ. of Wisconsin Press, 1992.

Dauber, Kenneth. The Idea of Authorship in America: Democratic Poetics from Franklin to Melville. Madison: Univ. of Wisconsin Press, 1990.

Davidson, Cathy. Revolution and the Word: The Rise of the Novel in America. New York: Oxford Univ. Press, 1986.

Davidson, Phebe. Religious Impulse in Selected Autobiographies of American Women (c. 1630-1893): Uses of the Spirit. Lewiston, N.Y.: Edwin Mellen, 1993.

De Man, Paul. The Rhetoric of Romanticism. New York: Columbia Univ. Press, 1984.

Delbanco, Andrew. The Puritan Ordeal. Cambridge: Harvard Univ. Press, 1989.

Dorsey, Peter. A. Sacred Estrangement: The Rhetoric of Conversion in Modern American Autobiography. University Park: Pennsylvania State Univ. Press, 1993.

—. "Women's Autobiography and the Hermeneutics of Conversion." a/b: Auto/ Biography Studies 8 (1993): 72-90.

Dos Passos, John. The Head and Heart of Thomas Jefferson. Garden City, N.Y.: Doubleday, 1954.

Douglas, Ann. The Feminization of American Culture. New York: Knopf, 1977.

Downing, Christine. "Re-Visioning Autobiography: The Bequest of Freud and Jung." Soundings 60 (1977): 210-28.

Drexler, Robert U. Guilty of Making Peace: A Biography of Nicholas P. Trist. Lanham, Md.: Univ. Press of America, 1991.

Dunn, Mary Maples. "Saints and Sisters: Congregational and Quaker Women in the Early Quaker Period." In Women in American Religion, ed. Janet Wilson James, 27-65. 
Eakin, Paul John. Fictions in Autobiography: Studies in the Art of Self-Invention. Princeton: Princeton Univ. Press, 1985.

- "Narrative and Chronology as Structures of Reference and the New Model Autobiographer." In Studies in Autobiography, ed. James Olney, 32-41.

- The New England Girl: Cultural Ideals in Hawthorne, Stowe, Howells and James Paul John Eakin. Athens: Univ. of Georgia Press, 1976.

- Foreword to On Autobiography, by Philippe Lejeune. Ed. Paul John Eakin. Minneapolis: Univ. of Minnesota Press, 1989.

- Introduction to American Autobiography: Retrospect and Prospect. Ed. Paul John Eakin. Madison: Univ. of Wisconsin Press, 1991.

Edkins, Carol. "Quest for Community: Spiritual Autobiographies of Eighteenth-Century Quaker and Puritan Women in America." In The Tradition of Women's Autobiography: From Antiquity to the Present, ed. Estelle C. Jelinek, 39-52.

Egan, Susanna. Patterns of Experience in Autobiography. Chapel Hill: Univ. of North Carolina Press, 1984.

Elliott, Emory. "The Development of the Puritan Funeral Sermon and Elegy: 1660-1750." Early American Literature 15 (1980): 151-64.

- "New England Puritan Literature." In The Cambridge History of American Literature. Vol. 1, 1590-1820, ed. Sacvan Bercovitch, 171-306.

- Revolutionary Writers: Literature and Authority in the New Republic 1725-1810. New York: Oxford Univ. Press, 1982.

Emerson, Everett. Puritanism in America, 1620-1750. Boston: Twayne, 1977.

Felski, Rita. Beyond Feminist Aesthetics: Feminist Literature and Social Change. Cambridge: Harvard Univ. Press, 1989.

Ferguson, Robert A. "The American Enlightenment." In The Cambridge History of American Literature. Vol. 1, 1590-1820, ed. Sacvan Bercovitch, 345-538.

—. "'We Hold These Truths': Strategies of Control in the Literature of the Founders." In Reconstructing American Literary History, ed. Sacvan Bercovitch, 1-28.

Ferling, John E. John Adams: A Life. Knoxville: Univ. of Tennessee Press, 1992.

Fichtelberg, Joseph. The Complex Image: Faith and Method in American Autobiography. Philadelphia: Univ. of Pennsylvania Press, 1989.

Fielder, Leslie A. Love and Death in the American Novel. New York: Criterion, 1960.

Fischer, David Hackett. Albion's Seed: Four British Folkways in America. New York: Oxford Univ. Press, 1989.

Fliegelman, Jay. Declaring Independence: Jefferson, Natural Language, $\mathcal{E}$ the Culture of Performance. Stanford: Stanford Univ. Press, 1993.

Prodigals and Pilgrims: The American Revolution against Patriarchal Authority, 1750-1800. New York: Cambridge Univ. Press, 1982.

Foster, Stephen. The Long Argument: English Puritanism and the Shaping of New England Culture, 1570-1700. Chapel Hill: Univ. of North Carolina Press, 1991.

Foucault, Michel. The History of Sexuality. Vol. 1, An Introduction. 1976. Translated by Robert Hurley. New York: Vintage Books, 1990.

Fowler, Lois J., and David H. Fowler, eds. Revelations of Self: American Women in Autobiography. Albany: SUNY Press, 1990. 
Friedman, Susan Stanford. "Women's Autobiographical Selves: Theory and Practice." In The Private Self:Theory and Practice of Women's Autobiographical Writings, ed. Shari Benstock, 34-62.

Frost, Jerry William. The Quaker Family in Colonial America: A Portrait of the Society of Friends. New York: St. Martin's Press, 1973.

Fuller, Margaret. Woman in the Nineteenth Century. 1855. New York: Norton, 1971.

Gilmore, Michael T. American Romanticism and the Marketplace. Chicago: Univ. of Chicago Press, 1985.

-The Middle Way: Puritanism and Ideology in American Romantic Fiction. New Brunswick: Rutgers Univ. Press, 1977.

Goodman, Katherine. Dis/Closures: Women's Autobiography in Germany Between 1790 1914. New York: Peter Lang, 1986.

Greene, Jack P., and J. R. Pole, eds. Colonial British America. Baltimore, Maryland: John Hopkins Univ. Press, 1984.

Greven, Philip. The Protestant Temperament:Patterns of Child-Rearing, Religious Experience, and the Self in Early America. New York: Knopf, 1977.

Gunn, Janel Varner. "Autobiography and the Narrative Experience of Temporality as Depth." Soundings 60 (1977): 194-209.

Gura, Philip F. A Glimpse of Sion's Glory: Puritan Radicalism in New England, 1620-1660. Middletown, Conn.: Wesleyan Univ. Press, 1984.

Hall, David D. Worlds of Wonder, Days of Judgment: Popular Belief in Early New England. Cambridge: Harvard Univ. Press, 1989.

Hall, David D., John M. Murrin, and Thad W. Tate, eds. Saints E Revolutionaries: Essays On Early American History. New York: Norton, 1984.

Hallgarth, Susan A. "Women Settlers on the Frontier: Unwed, Unreluctant, Unrepentant." Women's Studies Quarterly 3-4 (1989): 6-13.

Harris, Susan K. Nineteenth-Century American Women's Novels. Cambridge: Harvard Univ. Press, 1990.

Hatch, Nathan O. The Democratization of American Christianity. New Haven: Yale Univ. Press, 1989.

Hayes, Kevin J. A Colonial Woman's Bookshelf. Knoxville: Univ. of Tennessee Press, 1996.

Hellenbrand, Harold. The Unfinished Revolution: Education and Politics in the Thought of Thomas Jefferson. Newark: Univ. of Delaware Press, 1990.

Herrnstein Smith, Barbara. "Narrative Versions, Narrative Theories." In On Narrative, ed. W. J. T. Mitchell, 205-19. Chicago: Chicago Univ. Press, 1981.

Hilfer, Anthony Channell. The Ethics of Intensity in American Fiction. Austin: Univ. of Texas Press, 1981.

Hinshaw, William Wade. Encyclopedia of American Quaker Genealogy, vol. 2. Ann Arbor: Edwards Brothers, 1938.

Hof stadter, Richard. America at 1750: A Social Portrait. New York: Knopf, 1971.

Howard, Leon. Literature and the American Tradition. Garden City, N.Y:: Doubleday, 1957.

Howe, Daniel Walker. "Franklin, Edwards, and the Problem of Human Nature." In Benjamin Franklin, Jonathan Edwards, and the Representation of American Culture, ed. Barbara B. Oberg and Harry S. Stout, 75-97. 
Huff, Cynthia. "That Profoundly Female, and Feminist Genre': The Diary as Feminist Practice." Women's Studies Quarterly 3-4 (1989): 6-13.

James, Janet Wilson, ed. Women in American Religion. Philadelphia: Univ. of Pennsylvania Press, 1980.

James, Sydney V. A People Among Peoples: Quaker Benevolence in Eighteenth-Century America. Cambridge: Harvard Univ. Press, 1963.

Jameson, Frederick. The Political Unconscious: Narrative as a Socially Symbolic Act. Ithaca: Cornell Univ. Press, 1981.

Jehlen, Myra. American Incarnation: The Individual, The Nation, and The Continent. Cambridge: Harvard Univ. Press, 1986.

Jelinek, Estelle C. "Introduction: Women's Autobiography and the Male Tradition." In Women's Autobiography: Essays in Criticism, ed. Estelle C. Jelinek, 1-20. Bloomington: Indiana Univ. Press, 1980.

- The Tradition of Women's Autobiography: From Antiquity to the Present. New York: Twayne, 1986.

Johnson, Paul David. "Jonathan Edward's 'Sweet Conjunction.'" Early American Literature 16 (1981/1982): 270-81.

Jordan, Constance. Introduction to PMLA 106, no. 5 (1991): 1036-39.

Juster, Susan. "'In a Different Voice': Male and Female Narratives of Religious Conversion in Post-Revolutionary America." American Quarterly 41 (1989): 34-62.

Kagel, Steven E. American Diary Literature: 1620-1799. Boston: G. K. Hall, 1979.

Karlson, Carol F., and Laurie Crumpaker, eds. Introduction to The Journal of Esther Edwards Burr 1754-1757. New Haven: Yale Univ. Press, 1984.

Kazin, Alfred. "Autobiography as Narrative." Michigan Quarterly Review 3 (1964): 210-16.

Kelley, Mary. Private Woman, Public Stage: Literary Domesticity in Nineteenth-Century America. New York: Oxford Univ. Press, 1984.

- ed. Introduction to Hope Leslie; Or, Early Times in the Massachusetts, by Catharine Maria Sedgwick. 1827. New York: Rutgers Univ. Press, 1987.

Kolodny, Annette. Introduction to The Travel Diary of Elizabeth House Trist: Philadel phia to Natchez, 1783-84, by Elizabeth House Trist. In Journeys in New Worlds: Early American Women's Narratives, ed. William L. Andrews, 183-200.

- The Land Before Her: Fantasy and Experience of the American Frontiers, 16301860. Chapel Hill: Univ. of North Carolina Press, 1984.

- The Lay of the Land: Metaphor as Experience and History in American Life and Letters. Chapel Hill: Univ. of North Carolina Press, 1975.

— . "Letting Go Our Grand Obsessions: Notes Toward a New Literary History of the American Frontiers." American Literature 64 (Mar. 1992): 1-18.

Krupat, Arnold. "American Autobiography: The Western Tradition." Georgia Review 35 (1981): 307-17.

- For Those Who Come After: A Study of Native American Autobiography. Berkeley and Los Angeles: Univ. of California Press, 1985.

Kuklick, Bruce. "The Two Cultures in Eighteenth-Century America." In Benjamin Franklin, Jonathan Edwards, and the Representation of American Culture, ed. Barbara B. Oberg and Harry S. Stout, 101-13. 
Lacey, Barbara E. "The World of Hannah Heaton: The Autobiography of an EighteenthCentury Connecticut Farm Woman." William \& Mary Quarterly 45 (1988): 280-304. Lang, Amy Schrager. Prophetic Women: Anne Hutchinson and the Problem of Dissent in the Literature of New England. Berkeley and Los Angeles: Univ. of California Press, 1987.

Lawrence, D. H. “Benjamin Franklin." In Studies in Classic American Literature. 15-27. 1923. New York: Penguin, 1977.

Lawson-Peebles, Robert. Landscape and Written Expression in Revolutionary America: The World Turned Upside Down. New York: Cambridge Univ. Press, 1988.

Leary, Lewis. Soundings: Some Early American Writers. Athens: Univ. of Georgia Press, 1975.

Lejeune, Philippe. "Autobiography and Social History in the Nineteenth Century." In On Autobiography, ed. Paul John Eakin, 163-84. Minneapolis: Univ. of Minnesota Press, 1989.

"The Genetic Study of Autobiographical Texts." Biography 14 (1991): 1-11.

Lemay, J. A. Leo. "Franklin and the Autobiography: An Essay on Recent Scholarship." Eighteenth-Century Studies 1 (1968): 185-211.

- "Hamilton's Literary History of the Maryland Gazette." William and Mary Quarterly 23 (1966): 273-85.

- Men of Letters in Colonial Maryland. Knoxville: Univ. of Tennessee Press, 1972. , ed. The Oldest Revolutionary: Essays on Benjamin Franklin. Philadelphia: Univ. of Pennsylvania Press, 1976.

Lentricchia, Frank. "Foucault's Legacy: A New Historicism?" In The New Historicism, ed. H. Aram Vesser, 231-42. New York: Routledge, 1989.

Levin, David. "The Autobiography of Benjamin Franklin: The Puritan Experimenter in Life and Art." Yale Review 53 (1964): 258-75.

. "Reason, Rhythm, and Style." In Benjamin Franklin, Jonathan Edwards, and the Representation of American Culture, ed. Barbara B. Oberg and Harry S. Stout, 17185.

- ed. The Puritan in the Enlightenment: Franklin and Edwards. New York: Rand McNally, 1963.

Lewis, R.W. B. The American Adam: Innocence, Tragedy, and Tradition in the Nineteenth Century. Chicago: Univ. of Chicago Press, 1955.

Mack, Phyllis. Visionary Women: Ecstatic Prophecy in Seventeenth-Century England. Berkeley and Los Angeles: Univ. of California Press, 1992.

Malone, Dumas. Jefferson and the Rights of Man. Boston: Little Brown and Company, 1951.

- Jefferson the Virginian. Boston: Little Brown and Company, 1948.

Marietta, Jack D. The Reformation of American Quakerism, 1748-1783. Philadelphia: Univ. of Pennsylvania Press, 1984.

Martin, Jay. Harvests of Change: American Literature, 1865-1914. Princeton: Princeton Univ. Press, 1967.

Martin, Wendy. An American Triptych: Anne Bradstreet, Emily Dickinson, Adrienne Rich. Chapel Hill: Univ. of North Carolina Press, 1984. 


\section{Bibliography}

Martz, Louis L. The Poetry of Meditation: A Study in English Religious Literature of the Seventeenth Century. New Haven: Yale Univ. Press, 1954.

Marx, Leo. The Machine in the Garden: Technology and the Pastoral Ideal in America. New York: Oxford Univ. Press, 1964.

- "Pastoralism in America." In Ideology and Classic American Literature, ed. Sacvan Bercovitch and Myra Jehlen, 36-69.

-The Pilot and the Passenger: Essays on Literature, Technology, and Culture in the United States. New York: OxfordUniv. Press, 1988.

Mason, Mary G. "The Other Voice: Autobiographies of Women Writers." In Autobiography: Essays Theoretical and Critical, ed. James Olney, 207-35. Princeton: Princeton Univ. Press, 1980.

Matthiessen, F. O. American Renaissance: Art and Expression in the Age of Emerson and Whitman. 1941. New York: Oxford Univ. Press, 1964.

May, Henry F. The Enlightenment in America. New York: Oxford, 1976.

McKinsey, Elizabeth. "American Wanderlust." American Quarterly 43 (Dec. 1991): 681-87.

Meyer, Donald H. The Democratic Enlightenment. New York: Putnam, 1976.

Micklus, Robert. The Comic Genius of Dr. Alexander Hamilton. Knoxville: Univ. of Tennessee Press, 1990.

- "The Delightful Instruction of Dr. Alexander Hamilton's Itinerarium." American Literature 60 (1988): 359-84.

—. "Dr. Alexander Hamilton's 'Modest Proposal.'" Early American Literature 16 (1981): 107-32.

Miller; J. Hillis, ed. Aspects of Narrative. New York: Columbia Univ. Press, 1971.

Miller, Perry. Errand into the Wilderness. Cambridge: Harvard Univ. Press, 1956.

- The New England Mind:The Seventeenth Century. Cambridge: Harvard Univ. Press, 1954.

Miller, William Lee. The Business of May Next: James Madison and the Founding. Charlottesville: Univ. of Virginia Press, 1992.

Minter, David. The Interpreted Design as a Structural Principle in American Prose. New Haven: Yale Univ. Press, 1969.

Misch, Georg. A History of Autobiography in Antiquity. Vol. 1, Berlin 1907. Cambridge: Harvard Univ. Press, 1951.

Moers, Ellen. Literary Women. Garden City, N.Y.: Doubleday, 1976.

Mogen, David, Mark Busby, and Paul Bryant, eds. The Frontier Experience and the American Dream. College Station: Texas A\&M Univ. Press, 1989.

Moran, Gerald F."'Sisters' in Christ: Women and the Church in Seventeenth-Century New England." In Women in American Religion, ed. Janet Wilson James, 47-65.

Murdock, Kenneth B. Literature and Theology in Colonial New England. 1949. Westport, Conn.: Greenwood, 1970.

Nussbaum, Felicity. "Heteroclites: The Gender of Character in the Scandalous Memoirs." In The New Eighteenth Century: Theory, Politics, English Literature, ed. Felicity Nussbaum and Laura Brown, 144-67.

_- "Toward Conceptualizing Diary." In Studies in Autobiography, ed. James Olney, 128-40. 
Nussbaum, Felicity, and Laura Brown, eds. The New Eighteenth Century: Theory, Politics, English Literature. New York: Methuen, 1987.

Oberg, Barbara B., and Harry S. Stout, eds. Benjamin Franklin, Jonathan Edwards, and the Representation of American Culture. New York: Oxford Univ. Press, 1993.

Olney, James. "The Autobiography of America." American Literary History 3 (Summer 1991): 376-95.

- Metaphors of Self: The Meaning of Autobiography. Princeton: Princeton Univ. Press, 1972.

- ed. Autobiography: Essays Theoretical and Critical. Princeton: Princeton Univ. Press, 1980.

- ed. Studies in Autobiography. New York: Oxford Univ. Press, 1988.

Olshen, Barry N. "Subject, Persona, and Self in the Theory of Autobiography." a/b: Auto/ Biography Studies 10 (1995): 5-16.

Pearce, Roy Harvey. The Continuity of American Poetry. Princeton: Princeton Univ. Press, 1961.

Person, Leland S. "The American Eve: Miscegenation and a Feminist Frontier Fiction." American Quarterly 37 (1985): 669-85.

Peterson, Linda H. Victorian Autobiography: The Tradition of Self-Interpretation. New Haven: Yale Univ. Press, 1986.

Peterson, Merrill D. Thomas Jefferson and the New Nation: A Biography. New York: Oxford Univ. Press, 1970.

Pike, Burton. "Time in Autobiography." Comparative Literature 28 (1976): 326-42.

Porter, Roger J. “Unspeakable Practices, Writable Acts: Franklin's Autobiography." Hudson Review 32 (1979): 229-38.

Porterfield, Amanda. Female Piety in Puritan New England:The Emergence of Religious Humanism. New York: Oxford Univ. Press, 1992.

Renker, Elizabeth M. "Declaration-Men' and the Rhetoric of Self-Presentation." Early American Literature 24 (1989): 120-34.

Ricouer, Paul. "Narrative Time." Critical Inquiry 7 (1980): 169-90.

Rose, Anne C. Transcendentalism as a Social Movement, 1830-1850. YaleUniv.Press, 1981.

Savelle, Max. Colonial Origins of American Thought. Princeton: Princeton Univ. Press, 1964.

Sayre, Robert F. The Examined Self: Benjamin Franklin, Henry Adams, Henry James. Princeton: Princeton Univ. Press, 1964.

—. "The Proper Study-Autobiographies in American Studies." American Quarterly 29 (1977): 241-62.

—. "The Worldly Franklin and the Provincial Critics." Texas Studies in Literature $\mathcal{E}$ Language 4 (1963): 512-24.

Schweitzer, Ivy. The Work of Self-Representation: Lyric Poetry in Colonial New England. Chapel Hill: Univ. of North Carolina Press, 1991.

Seelye, John. Prophetic Waters: The River in Early American Life and Literature. New York: Oxford Univ. Press, 1977.

Shain, Barry Alan. The Myth of American Individualism: The Protestant Origins of American Political Thought. Princeton: Princeton Univ. Press, 1994. 


\section{Bibliography}

Shaw, Peter. The Character of John Adams. Chapel Hill:Univ. of North Carolina Press, 1976. Shea, Daniel B., Jr. Introduction to Some Account of the Fore Part of the Life of Elizabeth Ashbridge, by Elizabeth Ashbridge. In Journeys in New Worlds: Early American Women's Narratives, ed. William L. Andrews, 119-46.

- Spiritual Autobiography in Early America. Princeton: Princeton Univ. Press, 1988.

Sher; Richard, and Smitten Sher. Scotland \& America in the Age of the Enlightenment.

Princeton: Princeton Univ. Press, 1990.

Shields, David S. Civil Tongues and Polite Letters in British America. Chapel Hill: Univ. of North Carolina Press, 1997.

Shuffelton, Frank. "In Different Voices: Gender in the American Republic of Letters." Early American Literature 25 (1990): 289-303.

Slotkin, Richard. Regeneration Through Violence: The Mythology of the American Frontier, 1600-1860. Middletown, Conn.: Wesleyan Univ. Press, 1973.

Smith, Henry Nash. Virgin Land:The American West as Symbol and Myth. Cambridge: Harvard Univ. Press, 1950.

Smith, Page. John Adams. 2 vols. New York: Doubleday, 1962.

Smith, Sidonie. "The Impact of Critical Theory on the Study of Autobiography: Marginality, Gender; and Autobiographical Practice." a/b: Auto/Biography Studies 3 (1987): $1-12$.

. "Performativity, Autobiographical Practice, Resistance." a/b: Auto/Biography Studies 10 (1995): 17-33.

- A Poetics of Women's Autobiography: Marginality and the Fictions of Self Representation. Indianapolis: Indiana Univ. Press, 1987.

Spacks, Patricia Meyer. The Female Imagination. New York: Avon Books, 1972.

Imagining a Self: Autobiography and Novel in Eighteenth-Century England. Cambridge: Harvard Univ. Press, 1976.

Spengemann, William C. The Adventurous Muse: The Poetics of American Fiction, 17891900. New Haven: Yale Univ. Press, 1977.

The Forms of Autobiography: Episodes in the History of a Literary Genre. New Haven: Yale Univ. Press, 1980.

—. "What Is American Literature?" Centennial Review 22 (1978): 119-38.

Spengemann, William C., and L. R. Lundquist. "Autobiography and the American Myth." American Quarterly 17 (1965): 501-19.

Spiller; Robert E, ed. The American Literary Revolution, 1783-1837. Garden City, N.Y.: Doubleday, 1967.

Stanton, Domna C. "Autobiography: Is the Subject Different?" In The Female Autograph: Theory and Practice of Autobiography from the Tenth to the Twentieth Century, ed. Domna C. Stanton, 3-20. Chicago: Univ. of Chicago Press, 1984.

, ed. The Female Autobiography: Theory and Practice of Autobiography from the Tenth to the Twentieth Century. Chicago: Univ. of Chicago Press, 1984.

Steele, Jeffrey. The Representation of the Self in the American Renaissance. Chapel Hill: Univ. of North Carolina Press, 1987.

Stone, Albert E. Autobiographical Occasions and Original Acts: Versions of American 
Identity from Henry Adams to Nate Shaw. Philadelphia: Univ. of Pennsylvania Press, 1982.

. "Modern American Autobiography: Texts and Transactions." In Fictions in Autobiography: Studies in the Art of Self-Invention, ed. John Paul Eakin, 95-120. Princeton: Princeton Univ. Press, 1985.

Stoneburner, Carol. "Introduction: Drawing a Profile of American Female Public Friends as Shapers of Human Space." In The Influence of Quaker Women on American History: Biographical Studies, ed. Carol Stoneburner and John Stoneburner, 1-55. Lewiston, N.Y.: Edwin Mellen Press, 1986.

Sturrock, John. "The New Model Autobiographer." New Literary History 9 (1977):51-63.

Swaim, Kathleen M. "Come and Hear': Women's Puritan Evidences." In American Women's Autobiography: Fea(s)ts of Memory, ed. Margo Culley, 32-56.

Taves, Ann. "Self and God in the Early Published Memoirs of New England Women." In American Women's Autobiography: Fea(s)ts of Memory, ed. Margo Culley, 57-74.

Tichi, Cecelia. New World, New Earth: Environmental Reform in American Literature from the Puritans through Whitman. New Haven: Yale Univ. Press, 1979.

Todd, Jane Marie. Autobiographics in Freud and Derrida. New York: Garland Publishing, 1990.

Tolles, Frederick B. Meeting House and Counting House: The Quaker Merchants of Colonial Philadelphia, 1682-1763. Chapel Hill: Univ. of North Carolina Press, 1948.

Tompkins, Jane. Sensational Designs: The Cultural Work of American Fiction 1790-1860. New York: Oxford Univ. Press, 1985.

Trevett, Christine. Women and Quakerism in the 17th Century. York: Ebor Press, 1991.

Turner, Frederick Jackson. The Significance of the Frontier in American History. New York: Henry Holt, 1920.

Tyler, Moses Coit. A History of American Literature 1607-1765. Putnam, 1879. Reprint, Ithaca: Cornell Univ. Press, 1949.

. The Literary History of the American Revolution 1763-1783. 1897. Reprint, Putnam, 1905.

Ulrich, Laurel Thatcher. Good Wives: Image and Reality in the Lives of Women in Northern New England: 1650-1750. New York: Oxford Univ. Press, 1980.

"Virtuous Women Found: New England Ministerial Literature, 1668-1735," In Women in American Religion, ed. Janet Wilson James, 67-87.

Van Doren, Carl. Benjamin Franklin's Autobiographical Writings. New York: Viking, 1945.

Van Gastel, Ada. "Franklin and Freud: Love in the Autobiography." Early American Literature 25 (1990): 168-82.

Wall, Helena M. Fierce Communion. Cambridge: Harvard Univ. Press, 1990.

Walzer, Michael. The Revolution of the Saints: A Study in the Origins of Radical Politics. Cambridge: Harvard Univ. Press, 1965.

Watkins, Owen C. The Puritan Experience: Studies in Spiritual Autobiography. New York: Schocken, 1972.

Weber, Max. The Protestant Ethic and the Spirit of Capitalism. 1905. Translated by Talcott Parsons. London: Allen \& Unwin, 1930. 


\section{Bibliography}

Weintraub, KarlJoachim. "Autobiography and Historical Consciousness." Critical Inquiry 1 (1975): 821-48.

—. "The Puritan Ethic and Benjamin Franklin." Journal of Religion 56 (1976): 22337.

- The Value of the Individual: Self and Circumstance in Autobiography. Chicago: Univ. of Chicago Press, 1978.

Weisbuch, Robert. Atlantic Double-Cross: American Literature and British Influence in the Age of Emerson. Chicago: Univ. Chicago Press, 1986.

Weiskel, Thomas. The Romantic Sublime: Studies in the Structure and Psychology of Transcendence. Baltimore: Johns Hopkins, 1976.

West, Jessamyn, ed. The Quaker Reader. New York: Viking Press, 1962.

White, Hayden. "Fictions of Factual Representation." In The Literature of Fact: Selected Papers from the English Institute, ed. Angus Fletcher, 21-44. New York: Columbia Univ. Press, 1976.

- "The Value of Narrativity in the Representation of Reality." Critical Inquiry 7 (1980): 5-27.

Wills, Garry. Explaining America: The Federalist. New York: Doubleday, 1981.

Inventing America: Jefferson's Declaration of Independence. New York: Doubleday, 1978.

Wilson, Douglas L. "Thomas Jefferson and the Character Issue." Atlantic Monthly, Nov. 1992, 57-74.

Winston, Elizabeth. Women and Autobiography: The Need for a More Inclusive Theory. Madison: Univ. of Wisconsin Press, 1977.

Withey, Lynne. Dearest Friend: A Life of Abigail Adams. New York: Macmillan, 1981.

Wong, Hertha D. Introduction to a/b: Auto/Biography Studies 7 (Fall 1992): 157-62.

Wood, Gordon S. The Radicalism of the American Revolution. New York: Knopf, 1992.

Ziff, Larzer. Literary Democracy: The Declaration of Cultural Independence in America. New York: Viking, 1981.

-Puritanism in America: New Culture in a New World. New York: Viking, 1973.

Zuckerman, Michael. "Identity in British America: Unease in Eden." In Colonial Identity in the Atlantic World, 1500-1800, ed. Nicholas Canny and Anthony Pagden, 115-57. 


\section{Index}

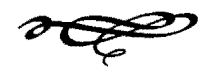

Adams, Abigail, xvii-xviii, 79, 114-16

Adams, Charles, 113

Adams, John

—advice to nieces, 113; ambition of, 148n; on American Revolution, 92-93; attitude about writing his autobiography, 86-87, 89; and Benjamin Franklin, 150n; on government, structure of, 100; on misrepresentation, 95-96, 105; personality of, 91, 148n; on public service, 92 ; signature of, 86 ; and Mercy Otis Warren, 89, 92

- Autobiography, xix, 89-91, 97, 99-100, 1023, 105-9; on being a lawyer; 90 ; family history, 90; on Franklin, 107-9; on Thomas Paine, 103; structure of, 89; tone and style of, 91; on Voltaire, 107; voyage to France, $113-14$

-and correspondence with Abigail Adams, on Boston occupation, 102, 115; on Continental Congress, xvii-xviii; on privacy, 105 ; romantic quality of, 115-16

-and correspondence with Thomas Jefferson, 103-4; on American Revolution, 92-93; beginnings of, 103; estrangement, periods of, 150n; and "Publicola" incident, 103-4

Adams, John Quincy, 89, 103-4, 113-14

Adams, Timothy Dow, 3-4

Aldridge, Alfred Owen, 136n

American Revolution, 87, 92-93, 100, 121

Anderson, Virginia DeJohn, 129n

Ashbridge, Elizabeth, xix, 15-33, 137n; marriages of, $138 \mathrm{n}$; signature of, 14

-Account, 17-33; arrives in America, 18; and conversion experience, 29-31; dream of female Quaker guide, 24-25; and father, 22,
25-26; and female ministers, 27-28; and gender, 19; as indentured servant, 22-26; literary sources for, 20-23; marriage to Sullivan, 26-32; and Quakers, 18, 23-33 authority, eighteenth-century sense of, 91-92 autobiography, and confessional voice, 5, 8,

$132 n$; instructional, xiv, 5 ; and selfexamination, 2; and self-representation, 2 4; term conceived, 2; and voice, xix, 1-2; see also eighteenth-century autobiography; political autobiography; spiritual autobiography; women's autobiography

Bailyn, Bernard, 87, 91

Bakhtin, Mikhail, 134n

Bell, Betty Louise, 87

Benstock, Shari, 130n-31n

Berbe-Marbois, François, 113

Bercovitch, Sacvan, $x v, 129 n$

Bogel, Fredric, 91

Bradford, William, xvii, xiv

Bradstreet, Anne, xvi, 128n, 133n, 137n

Breitenbach, William, 135n

Brereton, Virginia, 138n-39n

Brown, Richard D., 50, 56-57, 134n, 142n-43n

Bruss, Elizabeth W., 130n

Burke, Edmund, 73

Burr, Anna, 5

Burr, Esther Edwards, 133n, 138n, 141n

Burstein, Andrew, 79, 88

Burwell, Nathaniel, 111

Butterfield, L. H., 89

Caldwell, Patricia, 127n-28n, 136n, 139n

Calvin, John, 127n 
Calvinism, 19-20, 37, 140n

Cambridge Platform of 1648, 136n

Cappon, Lester J., 150n

captivity narrative, $3,14,21,139$ n

Carr, Peter, 111-12

Chase, Samuel, 95

Chastellux, Marquis de, 151n

Child, Lydia, 75

Cohen, Charles Lloyd, 136n

Commager, Henry Steele, 91, 149n-50n

Congregationalist movement, 16

Continental Congress, Second, 69, 92-93, 103

conversion experience, $14,31,38,136 n-37 n$

conversion narrative, $15,136 \mathrm{n}$

Cooper, James Fenimore, 84-85, 147n

Cosway, Maria, 79, 105, 116-21

Cott, Nancy, 16, 137n

Couser, G. Thomas, $132 \mathrm{n}$

Cox, Stephen, 131n

Crevecoeur, Michel-Gullaume-Jean de (J. Hector St. John de), 69, 84

Crumpaker, Laurie, 133n, 138n, 141n

Culley, Margo, xv, 146n

Davidson, Cathy, 112, 150n

Davidson, Phebe, $140 \mathrm{n}$

De Man, Paul, 3-4, 132n

Declaration of Independence, 92-94, 96-97

democratic leader, defined, 98-100; and domestic sphere, 109-15; compared to King George III and Louis XVI, 100; and social change, 98-99

divine will, 14, 17, 34

Divinity, as paternal figure, 18-20; perceptions of, $15,31,34,37-38$

Drexler, Robert U., 144 n

Eakin, Paul John, 130n

Edwards, Jonathan, xix, 14-20, 33-38, 71; signature of, 14

-Personal Narrative, 17, 19-20, 33-38; and nature, 35-38; and "Sinners in the Hands of an Angry God, " 36-37

Edwards, Timothy, 33

eighteenth-century autobiographer, 4-5, 9-13; and autobiography, defined, 123-26; and character, construction of, 11; and selfexamination, 4

election, 127n, 133n

Elliott, Emory, 36, 112, 128n-29n, 138n

Emerson, Ralph Waldo, xvi, 12, 136n

Enlightenment, and autobiography, 2; and experiential knowledge, 4, 15 evangelical family, $138 \mathrm{n}$

evangelical movement, 15, 136n

Felski, Rita, 9, 15, 132n

Ferguson, Robert A., 96, 149n

Ferling, John, 91, 148n

first-person narrative, and anonymity, pose of, 106; and diary, 5-9, 146n; and journal, as literary text, 4-5; and narrative fragmentation, 4-5; and self-construction, 4-5, 112, 122; and self-examination, xiv-xvi; and subjectivity, xiii, xv; see also letter

Fischer, David Hackett, 140n

Fliegelman, Jay, 21, 88, 96, 109, 147n-49n, 151n

Foster, Mrs., and The Coquette, 21-22

Foster, Stephen, 127n

Foucault, Michel, 132n-33n

Fowler, David H., 138n

Fowler, Lois J., 138n

Franklin, Benjamin, and John Adams, 107-8; and the Autobiography, 10-12, 84, 87, 135n; compared to Emerson and Thoreau, 136n; and Poor Richard persona, 106

French Revolution, 92, 100-102

Friedman, Susan Stanford, 151n

Frost, Jerry, 139n

Fuller, Margaret, 139n

Gilmore, Michael, 35

Great Awakening, 15-18, 34, 45-47, 136n

Greven, Philip, 91, 109, 138n

Gura, Philip F., 127n-29n

Hall, David D., 7

Hamilton, Dr. Alexander, xix, 40-65, 84-85; and caricatures, 50-54, 57-58; and class issues, 47, 57-59; and Clubs, 49-51, 63, $142 n-43 n$; and Dromo, servant of, 56 ; and the Dutch, 59; journey of, 44-69; literary interests of, 55, 64; marriage of, 143n; and Native Americans, 59-61; and religion, 4548; and Restoration comedy, 45, 64; romantic reactions to nature, 54-55; and sentimental novel, 64; signature of, 40 ; and Tuesday Club, 56, 143n; and women, 61-65

-Itinerarium, 44-65, 68, and agriculture, 52; Albany, 52, 59-60,62-63; and architecture, 53-54; Bohemia Ferry, 45; Boston, 46, 49, 51-53, 59, 63-65; Branford, 54; Brookhaven, 57; Buttermilk Island, 55; Catskills, 52; Chester, 51, 53-54; and commerce, 52; Connecticut River, 46; Cook's Island, 54; Hudson River, 54; and King George's War, 
61; Kingsbridge, 60 ; map of, 42-43; and Maryland, 49, 58, 61, 63; medical discussions in, 54; Mount Hope, 60; Narrows Ferry, 47; New Castle, 50; and New Lights, 46; New London, 47; New York, 50-51, 53, 55, 59, 6163; Newport, 48, 54, 62, 64; Newtown, 51; note on text, 141n-42n; Oversleigh, 59; Perth Amboy, 56; Philadelphia, 45-50, 5253, 56, 61-62; Portsmouth, 50, 58;

"Princetown," 52; Rhode Island, 55;

Schenectady, 59-60; Seabrook, 63; Stonnington, 49; Susquehanna Ferry, 45; Tower Hill, 54; Trenton, 56; Whitehall, 68; York, 63; York Ferry, 62; York Island, 60 Hart, Albert Bushnell, 57, 59

Hayes, Kevin J., 29, 140n

Heaton, Hannah, 133n, 139n-40n

Hellenbrand, Harold, 99

Hof stadter, Richard, 140n-41n

Hogarth, William, 56

Howe, Daniel Walker, 17-18

Hutchinson, Anne, xvi, 16, 137n

individualism, xvi; and authority, 13, 91-92; and democratic self, xvii

Jefferson, Martha (wife), death of, 109, 146n, $151 \mathrm{n}$

Jefferson, Martha ("Patsy") (daughter), 11011,117

Jefferson, Thomas, xix, 69, 86-89, 91-95; correspondence, volume of, 150n; and Maria Cosway, 105, 116-21; on fiction, 11112; "Head and Heart Letter," 116-21; signature of, 86; as single parent, 109-12; and Laurence Sterne, 112, 152n; Elizabeth House Trist, correspondence with, 77-84; wife, death of, 109, 146n, 151n; on wild horses, $144 n-45 n$; see also John Adams; Elizabeth House Trist

- Autobiography, 87-89, 91, 93-97, 99-102; and American Revolution, 92-93, 100; and Articles of Confederation, debates over, 94; attitude about writing, 86-88, 106; and College of William and Mary, 106; and Declaration of Independence, 92-94, 96-97; family history of, 88; and French Revolution, 100-102; and King George III, 94, 96; and Lafayette, 100; and Marie Antoinette, 101; and primogeniture laws, 99; and slavery, 94-95; structure of, 87-88; tone and style of, 91; and wrist accident, 116-17

--on education, for daughter, "Patsy," 110; for female in general, 111-12; for nephew, Peter Carr, 111

-letters, to Abigail Adams, 98; to Marquis de Chastellux, 151n; to Maria Cosway, 105, 116-21; to Samuel Kercheval, 98; to James Madison, 116, 143n, 146n

Jehlen, Myra, 44

Jordan, Constance, 130n

Juster, Susan, 136n

Karlson, Carol F., 133n, 138n, 141n

Kercheval, Samuel, 98

King George III, 94, 96, 100

Koch, Adrienne, 150n

Kolodny, Annette, 73, 76, 141n, 144n

Kuklick, Bruce, $141 \mathrm{n}$

Lacey, Barbara E., 133n, 139n-40n

Lejeune, Philippe, 3, 131n, 133n-34n

Lemay, J. A. Leo, 55, 58, 143n

Lentricchia, Frank, 130n

letter, delays in receiving, $146 n$; and idealized self, 105; as literary text, 4 ; and private self, 103

Levin, David, 137n-38n, 140n

Locke, John, 4, 97, 109, 115, 140n-41n, 150n$51 \mathrm{n}$

Madison, James, 69, 116, 143n, 146n

Malone, Dumas, $147 \mathrm{n}$

Marietta, Jack D., 139n-40n

Martin, Wendy, 128n, 134n

Martz, Louis L., 133n

Marx, Leo, 76

Mason, Mary G., 137n

Mather, Cotton, 36

May, Henry F., 150n

McKinsey, Elizabeth, 142n-43n

Micklus, Robert, 41, 47, 58, 60, 141n-43n

Miller, Perry, 6, 128n, 140n

Minter, David, 134n

Misch, Georg, 2, 132n

Moll Flanders, 3

Monroe, James, 69

Morton, Thomas, 133n

Murdock, Kenneth B., 6

Native Americans, $144 n$; see also Dr. Alexander Hamilton; Elizabeth House Trist

New Historicism, xix, 130n

New Republic, xvi, 91, 109

Northampton Controversy, 34-35

Nussbaum, Felicity, 9, 24, 138n-39n 
Olshen, Barry N., 130n

oral culture, and gossip, 8, 57, 143n

Paine, Thomas, 103-4

Peden, William, 150n

Penn, William, 27

Person, Leland, 75

Peterson, Merrill D., 88, 91, 147n

political autobiography, 86-122; and autobiographer, 5; defined, 86, 122-23; personal disclosure in, 89 ; and public and private self, 87-88; and self-examination, 91 ; and selfrepresentation, 87; and subjectivity, 102; see also John Adams; Thomas Jefferson

Pope, Alexander, 4

population, colonial-New Republic, xvi, 53, $129 n, 142 n, 144 n$

Porterfield, Amanda, 16, 137n

Protestantism, xiv-xv, 16

Providential Design, xiv, 6

Puritan, and Puritanism, xiv, xvii, and firstperson narrative, 1, 6-9; leader, defined, 129n; see also Jonathan Edwards; Samuel Sewall

Puritan Diary, xiv, 6-9

Quakers, 18; doctrine of, 23, 30, 140n; and dreams, 139n; and female ministers, 19; see also Elizabeth Ashbridge

Renker, Elizabeth M., 93, 148n-49n

Richardson, Samuel, 21, and Clarissa, 21-23, 112,135n-36n; and Pamela, 21, 23

Romantic, xvi; and autobiography, 1-2, 13; and community, 2

Rousseau, Jean-Jacques, 109

Rowlandson, Mary, and Narrative of the Captivity, 3, 21

Rowson, Susanna, and Charlotte Temple, 21-22

Sayre, Robert F., 130n, 132n, 134n

Schweitzer, Ivy, xvi, 129n

Scottish Common Sense School, 112

Sedgwick, Catherine Maria, 75, 85, 139n

Seelye, John, 6, 135n

self-disclosure, expectations of, 13; and gender, 5; see also John Adams; Thomas Jefferson

self-examination, xiii-xix; and community, $\mathrm{xiv}-\mathrm{xv}, \mathrm{xix}$; and female spirituality, 16 , $137 \mathrm{n}$; and Puritanism, 6-9, 133n; and selfconstruction, 1-13, 123-24; and women, xvi, 138n-39n

sentimental style, 11, 22, 24
Sewall, Samuel, 6-8, 30, 37, 64, 71, 134n; Diary of, 6-8

Shain, Barry, 128n, 147n-49n

Shaw, Peter, $148 \mathrm{n}$

Shea, Daniel, 27, 137n, 139n, 141n

Shields, David S., 9, 51

Shuffelton, Frank, 56, 89

slave narrative, as literary text, 4

slavery, 94; Jefferson on, 94-95

Slotkin, Richard, xv, 127n, 139n-41n, 147n

Smith, John, 133n

Smith, Sidonie, 130n-32n, 135n

Southey, Robert, 2, 130n

Spacks, Patricia Meyer, 3, 131n

Spectator, 56, 106

Spengemann, William, 9, 142n

Spenser, Edmund, and Faerie Queene, 55

spiritual autobiographer, xiii, 5, 14-39, 123

spiritual autobiography, 14-39; and captivity narrative, 21; and contemplation and nature, 36; and gender issues, 15-20, 33, 35, $38-39,137 \mathrm{n}$; and the novel, 26 ; see also Elizabeth Ashbridge; Jonathan Edwards

Sterne, Laurence, $112,152 \mathrm{n}$

Stone, Albert, 131n

Swaim, Kathleen M., 128n, 134n

Tattler, 56, 106

Taves, Ann, 136n-37n

Tichi, Cecelia, 76, 134n

Transcendentalism, xiii, xvi, 35, 38-39

travel narrative, 4-5, 40-85, 123; defined, 40$41,44,58-59,77$; subjectivity and, 44, 63, 80, 84-85; see also Dr. Alexander Hamilton; Elizabeth House Trist

Trist, Elizabeth House, xix; family of, 69, 83, $143 n$; signature of, 40

—and Thomas Jefferson correspondence, 77-84, 110-11, 116-17, 145n-46n, 148n, 151n-52n

-Travel Diary, 41, 69-84; accommodations, 70-71, 79-80; audience for, 79-80; Balize (Acadian Coast), 81-83; community, concerns for, 69-70, 82; crops and resources, 70, 79-80; and dangers of travel, 74, 77-78; environmental issues, 71; hunting and, 72; map of, 66-67; Natchez (Louisiana territory), 41, 69; Native Americans and, 75; nature, attitudes toward, 71-76, 83-84; Philadelphia, departs from, 69; Pittsburgh, $41,69,78,81,145 \mathrm{n}$

Trist, Hore Browse (son), 69, 145n-46n

Trist, Nicholas (husband), 41, 69, 81, 144n, 146n

Turner, Frederick Jackson, 144n 
Ulrich, Laurel Thatcher, 16

Van Gastel, Ada, 135n

virtue, 11-12, 25-26, 135n

Voltaire, François Marie Arouet, 107

Wall, Helena M., xiv-xv, 8, 109, 127n, 134n, 139n, 150n-51n

Walzer, Michael, xv, 129n, 134n

Warren, Mercy Otis, 89, 92

Watkins, Owen C., 34, 136n

Weintraub, Karl, 6

Weisbuch, Robert, 151n
Weiskel, Thomas, 55

Whitefield, Rev. George, 45

Wills, Garry, 96-97, 149n

Winthrop, John, xiv, xvii

women's autobiographical writings, 138n-39n, 151n; see also Elizabeth Ashbridge; Elizabeth House Trist

Wood, Gordon S., 15, 109, 115, 129n, 131n, $148 \mathrm{n}-49 \mathrm{n}$

Ziff, Larzer; $x v, 127 \mathrm{n}$

Zuckerman, Michael, 127n

Declarations of Independency in Eighteenth-Century American Autobiography was typeset on a Macintosh computer system using PageMaker software. The text and titles are set in Aldus. This book was designed by Valerie Hembree, composed by Kimberly Scarbrough, and manufactured by Thomson-Shore, Inc. The recycled paper used in this book is designed for an effective life of at least three hundred years. 
